University of Louisville

ThinkIR: The University of Louisville's Institutional Repository

Electronic Theses and Dissertations

$12-2008$

\title{
St. Ambrose and the architecture of the churches of northern Italy : ecclesiastical architecture as a function of liturgy.
}

Sylvia Crenshaw Schneider 1948-

University of Louisville

Follow this and additional works at: https://ir.library.louisville.edu/etd

\section{Recommended Citation}

Schneider, Sylvia Crenshaw 1948-, "St. Ambrose and the architecture of the churches of northern Italy : ecclesiastical architecture as a function of liturgy." (2008). Electronic Theses and Dissertations. Paper 1275.

https://doi.org/10.18297/etd/1275

This Master's Thesis is brought to you for free and open access by ThinkIR: The University of Louisville's Institutional Repository. It has been accepted for inclusion in Electronic Theses and Dissertations by an authorized administrator of ThinkIR: The University of Louisville's Institutional Repository. This title appears here courtesy of the author, who has retained all other copyrights. For more information, please contact thinkir@louisville.edu. 


\title{
ST. AMBROSE AND THE ARCHITECTURE \\ OF THE CHURCHES OF NORTHERN ITALY:
}

\section{ECCLESIASTICAL ARCHITECTURE AS A FUNCTION OF LITURGY}

\author{
By \\ Sylvia Crenshaw Schneider \\ B.A., University of Missouri, 1970

\begin{abstract}
A Thesis
Submitted to the Faculty of the Graduate School of the University of Louisville in Partial Fulfillment of the Requirements for the Degree of
\end{abstract}

Master of Arts

Department of Art History

University of Louisville

Louisville, Kentucky

December 2008 

Copyright 2008 by Sylvia A. Schneider

All rights reserved 


\author{
ST. AMBROSE AND THE ARCHITECTURE \\ OF THE CHURCHES OF NORTHERN ITALY: \\ ECCLESIASTICAL ARCHITECTURE AS A FUNCTION OF LITURGY \\ By \\ Sylvia Crenshaw Schneider \\ B. A., University of Missouri, 1970 \\ A Thesis Approved on
}

November 22, 2008

By the following Thesis Committee:

Dr. Karen Britt, Thesis Director

Dr. Linda Gigante

Dr. Blake Beattie 


\section{DEDICATION}

This thesis is dedicated to my mother

Marianne Louise Lukas Crenshaw

A very great lady who survived interesting times

with verve and an unrestrained curiosity.

She taught me to love books. 


\section{ACKNOWLEDGMENTS}

I would like to thank my thesis advisor, Dr. Karen Britt, for her endless patience and guidance. Her enthusiasm for medieval studies, the depth and breadth of her scholarship, and the example of her discipline are an inspiration to all her students. To those qualities she brings a genuine concern for her students' welfare, and the warm interest of friendship. With her, I would also like to thank the other members of my committee, Dr. Blake Beattie and Dr. Linda Gigante, for paying me the tremendous compliment of reading it critically.

Additionally, I would like to acknowledge the support of my sister, Linda Crenshaw Mazzucchi, and dear friends, Ann Leide, Rita Carmean, and Ceil Dorger. They brought a critical ear to the loop of endless talk, and if they wearied of it, they were kind enough not to show it. Their encouragement and their laughter never faltered; in hard times, the journey would have been unbearably lonely without the support of this loving community of women.

Finally, I would like to thank my children, Christopher David Schneider and Andrea Joan Schneider Legg, for their encouragement and support, and for making me believe that I have played some small part in the development of their beauty and their decency. 


\title{
ABSTRACT \\ ST. AMBROSE AND THE ARCHITECTURE \\ OF THE CHURCHES OF NORTHERN ITALY:
}

\section{ECCLESIASTICAL ARCHITECTURE AS A FUNCTION OF LITURGY}

\author{
Sylvia Crenshaw Schneider
}

December, 2008

This thesis argues that the architecture of the churches of northern Italy that were constructed during the fifth and sixth centuries reflected the influence and vision of Ambrose, bishop of Milan (374-397), whose spiritual authority, theologically and liturgically, militantly extended the ecclesiastical authority of the see of Milan. In particular, this thesis demonstrates that the hegemony of the see of Milan in northern Italy was implemented in the architectural accommodation of the distinctive Ambrosian liturgy of Milan.

To develop this argument, this thesis has adopted an integrated approach to the political and ecclesiastical history of northern Italy in the fourth century, divided into seven chapters, concentrating on the Ambrosian liturgy, the Ambrosian foundations and the derivative foundations that expressed the architectural influence of the Milanese see. As much as possible, inferences have been drawn from the writings of St. Ambrose and his contemporaries. 
TABLE OF CONTENTS

PAGE

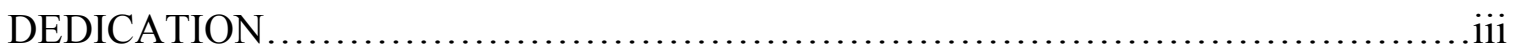

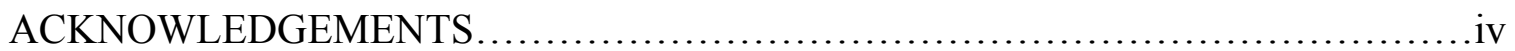

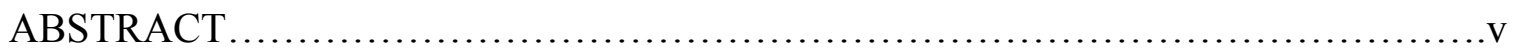

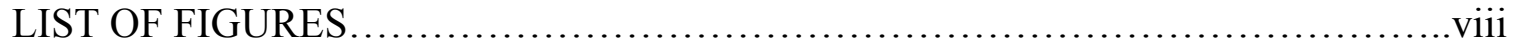

CHAPTER

I. INTRODUCTION................................................

The Development of the Northern Italian Christian Communities.........5

The Imperial Presence in Milan: Ecclesiastical Politics..................13

II. AMBROSE OF MILAN...................................... 22

III. THE EPISCOPACY OF AMBROSE...............................42

The Early History of the See of Milan...............................42

The Churches of Milan at the Time of Ambrose's Accession.............53

IV. THE AMBROSIAN LITURGY ..................................68

Early Liturgical Sources.......................................69

The Ambrosian Rite.............................................. 74

Liturgical Practice in Milan........................................76

Missa Catechumenorum.........................................78

Missa Fidelium................................................8 89

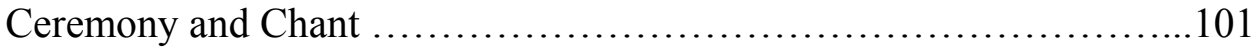


The Sacrament of Baptism ......................................104

The Cult of the Saints................................................. 114

The Finding of Gervasius and Protasius............................ 126

V. THE AMBROSIAN FOUNDATIONS ..............................132

The Basilica Martyrum..................................................137

The Basilica Apostolorum............................................... 144

The Basilica Virginum........................................... 157

S. Giovanni alle Fonti (baptistery) ................................. 162

VI. THE DERIVATIVE FOUNDATIONS............................ 170

Verona: S. Stefano.......................................... 176

Vicenza: SS. Felice e Fortunato............................. 181

Padua: S. Prosdicimus (chapel).................................185

Ravenna: The Neonian Baptistery............................188

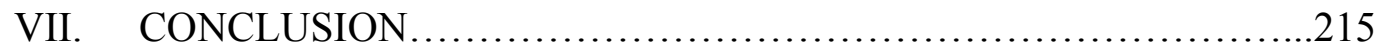

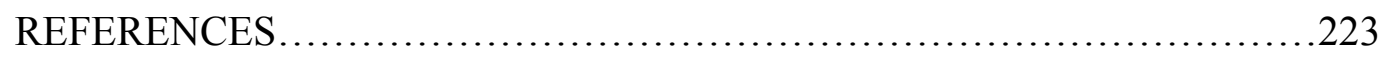

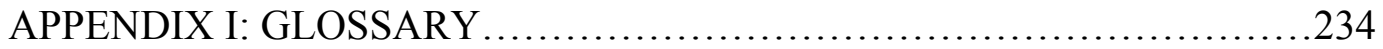

APPENDIX II: AMBROSE, EPISTOLA, XXII.............................244

APPENDIX II: RITES OF THE CATHOLIC CHURCH......................249

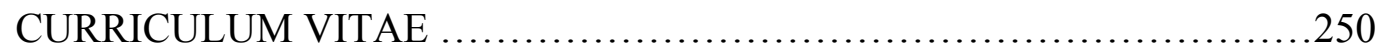




\section{LIST OF FIGURES}

FIGURE PAGE

1. The Missionary Journeys of St. Paul.......................... 5

(The Church of Jesus Christ of Latter Day Saints, The Scriptures Internet Edition, http://scriptures.lds.org/biblemaps/13)

2. Northern Italy, showing the prefecture of Aemilia-Liguria and the road from Milan to Aquileia.

( McLynn, Ambrose of Milan, 283)

3. Northern Italian Conciliar Participation, 313-359.

(Humphries, Communities of the Blessed, 51)

4. Timeline of imperial residence in Milan........................... 15

(Author's reconstruction)

5. Milan, S. Ambrogio: The body of St. Ambrose between SS Gervasius and Protasius.................................................. 31

(Crook, Architectural Setting of the Cult of the Saints, 15)

6. Ambrose leaves Rome as Govenor of Aemilia-Liguria............. 32

(Hahn, "Golden Altar of Sant'Ambrogio," Dumbarton Oaks 53, Fig. 9)

7. Ambrose Attempts to Flee Milan and Is Stopped by the Holy Spirit... 32 (Hahn, "Golden Altar of Sant'Ambrogio," Dumbarton Oaks 53,

Fig. 10)

8. Milan: Gervasius, S. Sartiro (S. Vittore in Ciel D’Oro) $\left(5^{\text {th }}\right.$ c. $) \ldots \ldots . .34$ (Brenk, "Homo Coelestis," Architettura e Imagini, Fig. 13)

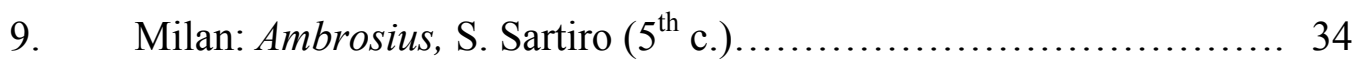
(Brenk, "Homo Coelestis," Architettura e Imagini, Fig. 12)

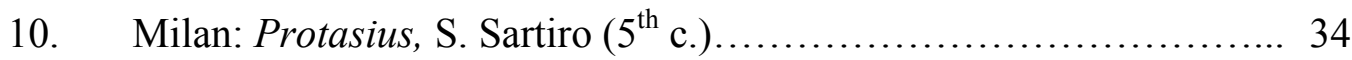
(Brenk, "Homo Coelestis," Architettura e Imagini, Fig. 14)

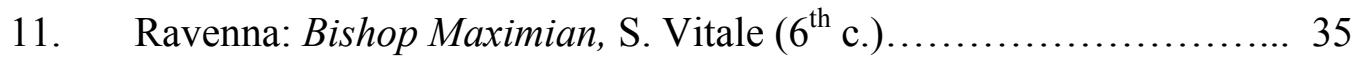
(Brenk, "Homo Coelestis," Architettura e Imagini, Fig. 15) 
12. Evangelist, The Book of Durrow, $\left(7^{\text {th }}\right.$ c. $)$ Celtic Tonsure............. 37 (http://library.thinkquest.org/C005417/bookdurr.htm)

13. Christian Dioceses of the fifth century........................ 43 (Jean Hubert, J. Porcher and W. F. Volbach; translated by Stuart Gilbert and James Emmons. Europe of the Invasions, frontispiece)

14. Late Roman and Early Christian Milan, c. 400 .

(Edwards (Lewis) "Two Critical Aspects of Fourth-Century Architecture at Milan)," 380, with additions by the author)

15. Piva's plan of the episcopal complex of Milan at the time of Ambrose's accession.

(Piva, "L'ipotetica basilica doppia di Milano," 132)

16. Double Cathedral of Aquileia (early fourth century)

(Humphries, Communities of the Blessed, 75)

17. Double Cathedral of Aquileia. stages of c. 313-319 and c. 350 or 400

(Krautheimer, Early Christian and Byzantine Architecture, 44)

18. Milan: The Baptisteries of the Episcopal Complex................ 56 (Temple, "Conversion and Political Expedience," 31)

19. Milan: S. Tecla and the Ambrosian baptistery of

S. Giovanni alle Fonti...

(Krautheimer, Early Christian and Byzantine Architecture, 84)

20. Rome, S. Giovanni in Laterano plan.

(Richard Krautheimer, "The Constantinian Basilica," Dumbarton Oaks,

21, Figure 8)

21. Milan: Three Phases of Reconstruction of S. Tecla

(Edwards (Lewis), "Two Critical Aspects of Fourth-Century Architecture at Milan," 390)

22. Milan: S. Lorenzo, plan (before 378)...

(Krautheimer, Early Christian and Byzantine Architecture, 79)

23. Milan: S. Lorenzo complex, southeast elevation.................. 60 (http://wings.buffalo.edu/AandL/Maecenas/italy_except_rome_and_sicily/milan/ac861604.html)

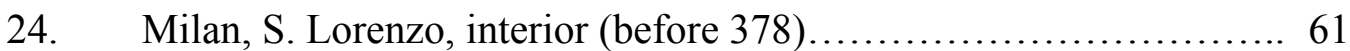
(http://wings.buffalo.edu/AandL/Maecenas/italy_except_rome_and_sicily/milan/ac861604.html) 
25. Milan: Reggioni's reconstruction of S. Vittore in Ciel d'Oro (4 $4^{\text {th }}$ c.).. 64 Edwards (Lewis), "Two Critical Aspects of Fourth-Century Architecture at Milan," 389)

26. Milan: S. Vincenzo in Prato, east side

(http://www3.villanova.edu/mission/Pellegrinaggio/2007/slide.pdf)

27. Milan: S. Vincenzo in Prato, interior. (http://www3.villanova.edu/mission/Pellegrinaggio/2007/slide.pdf)

28. Milan: The Remains of S. Giovanni in Conca. 66 (http://www3.villanova.edu/mission/Pellegrinaggio/2007/slide.pdf)

29. Milan: Sant'Eustorgio (front and right sides). (http://www3.villanova.edu/mission/Pellegrinaggio/2007/slide.pdf)

30. Rome: Plan of the Forum of Trajan, $98-128 \ldots \ldots \ldots \ldots \ldots \ldots \ldots . . .61$ (http://www.students.sbc.edu/smith04/plan\%20of\%20Trajan\%20forum.gif)

31. An early Christian chancel arrangement (after Mathews) 82 (Mathews, "Early Christian Chancel Arrangement," 94)

32. Gerasa: SS Peter and Paul, early Christian chancel with ambon $\left(5^{\text {th }} \mathrm{c}.\right) 86$ (MacDonald, Early Christian \& Byzantine Architecture, Fig. 8)

33. Early Christian templon and altar.

(Anson, Churches: Their Plan \& Furnishing, 65)

34. Fraction of the Host $\left(6^{\text {th }}\right.$ c. $)$..... (Duchesne, Christian Worship, 219)

35. Milan: 2005 Ordination of Priests at the Cathedral. 95 (http://www.chiesadimilano.it/)

36. Duro Europos, Syria: Christian Baptistery, c. 231 (Reconstruction)... 113 (Lowden, Early Christian and Byzantine Art, 20)

37. Rome: Reconstruction of Old St. Peters, c. 400 showing the separate Baptistery

38. Milan: The Lighting of the Faro (http://www.newliturgicalmovement.org/2008/02/lighting-of-faro-in-ambrosianrite.html) 
39. Salonika: Hagia Sophia (early $8^{\text {th }}$ c.?) Ambulatory church with three apses, (isometric reconstruction)

(Krautheimer, Early Christian and Byzantine Architecture, 517)

40. Rome, Cemetery complex of S. Alessandro.

(Crook, The Architectural Setting of the Cult of the Saints, 41)

41. Rome, S. Alessandro. Altar over the tomb of SS. Eventius and Alexander, elevation, plan and section. After Robault de Fleury (18831839)

(Crook, The Architectural Setting of the Cult of the Saints, 42)

42. Rome: Isometric reconstruction of S. Lorenzo fuori le mure (c. 330).. 125 (Krautheimer, Early Christian and Byzantine Architecture, 52)

43. Milan: c. 400......

(Krautheimer, Three Christian Capitals, 73)

44. Milan: Sant' Ambrogio (B. Martyrum), foundation of $4^{\text {th }}$ c. column... 135 (Krautheimer, Three Christian Capitals, 78)

45. Milan: Sant'Ambrogio (B. Martyrum), $4^{\text {th }}$ c. opus spicatum masonry. 136 (http://www3.villanova.edu/mission/Pellegrinaggio/2007/slide.pdf)

46. Milan: S. Simpliciano (B. Virginum), $4^{\text {th }}$ c. opus spicatum masonry... 136 (Krautheimer, Three Christian Capitals, 78)

47. Milan: B. Martyrum in the Coemeterium ad Martyres, 386 138 (Edwards (Lewis), "Two Critical Aspects of Fourth-Century Architecture at Milan," 387)

48. Milan: B. Martyrum (Sant'Ambrogio) $4^{\text {th }}$ c. plan showing the atrium and chapel of S. Vittore in Ciel d'Oro, as well as the original apse and altar placement

(Edwards (Lewis), "Two Critical Aspects of Fourth-Century Architecture at Milan," 388)

49. Milan: Sant'Ambrogio, the altar and ciborium $\left(11^{\text {th }} \mathrm{c}.\right)$

(http://www3.villanova.edu/mission/Pellegrinaggio/2007/slide.pdf)

50. Milan: Sant'Ambrogio, west wall showing the forecourt. (http://www3.villanova.edu/mission/Pellegrinaggio/2007/slide.pdf)

51. Milan: Present day Sant'Ambrogio complex (http://www3.villanova.edu/mission/Pellegrinaggio/2007/slide.pdf) 
52. Milan: Sant'Ambrogio, northeast wall and apse.

(http://www3.villanova.edu/mission/Pellegrinaggio/2007/slide.pdf)

53. Milan: Location of B. Apostolorum on the Via Romana............. 145 (McLynn, Ambrose of Milan, 233)

54. Milan: Isometric reconstruction of the B. Apostolorum showing segment of the propylaeum of the Via Romana

(Lewis, "Function and Symbolic Form," 87)

55. Milan: B. Apostolorum, topographical context

(Edwards (Lewis), "Two Critical Aspects of Fourth-Century Architecture at Milan," 381)

56. Constantinople: Plan of the Church of the Apostles (330) (http://campus.belmont.edu/honors/byzart2001/byzindex.html)

57. Constantinople: Isometric reconstruction of the Church of

The Apostles

(http://campus.belmont.edu/honors/byzart2001/byzindex.html)

58. Antioch-Kaoussié: Isometric reconstruction of St. Babylas....

(Brenk, "Pelligrinagio e Culto," Architettura e Imagini, Fig. 11)

59. Antioch-Kaoussié: Plan of St. Babylas.

(Krautheimer, Early Christian and Byzantine Architecture, 76)

60. Milan: Plan, B. Apostolorum.

(Brenk, "Pelligrinagio e Culto," Architettura e Imagini, Fig. 9)

61. Milan: B. Apostolorum, reconstruction of the triple arcade.... (Lewis, "Function and Symbolic Form," 89)

62. Milan: S. Nazaro, nave and transverse arches

(http://www3.villanova.edu/mission/Pellegrinaggio/2007/slide.pdf)

63. Milan: S. Nazaro, east façade.

(http://www3.villanova.edu/mission/Pellegrinaggio/2007/slide.pdf

64. Milan: S. Nazaro, exedra of the west lateral..................... 156

(http://www3.villanova.edu/mission/Pellegrinaggio/2007/slide.pdf)

65. Milan: S. Simpliciano, east façade.

(http://www3.villanova.edu/mission/Pellegrinaggio/2007/slide.pdf) 
66. Dimensions of B. Virginum.................................. 157

(Author's reconstruction)

67. Milan: S. Simpliciano, north façade.......................... 157 (http://www3.villanova.edu/mission/Pellegrinaggio/2007/slide.pdf)

68. Milan: S. Simpliciano, south façade.......................... 158 (http://www3.villanova.edu/mission/Pellegrinaggio/2007/slide.pdf)

69. Milan: Plan of B. Virginum with cruciform oratory............... 159 (Edwards (Lewis), "Two Critical Aspects of Fourth-Century Architecture at Milan," 403)

70. Milan: S. Simpliciano, interior showing the transverse crossing....... 160 (http://www3.villanova.edu/mission/Pellegrinaggio/2007/slide.pdf)

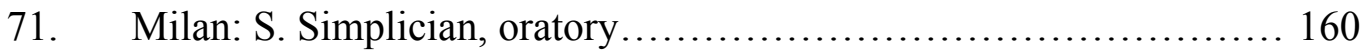
(http://www3.villanova.edu/mission/Pellegrinaggio/2007/slide.pdf)

72. Milan: Remains of octagonal wall and chapel of S.Gregorio. (Edwards (Lewis), "Two Critical Aspects of Fourth-Century Architecture at Milan," 386)

73. Milan: Chapel of S. Gregorio (imperial mausoleum)

(Edwards (Lewis), "Two Critical Aspects of Fourth-Century Architecture at Milan," 384)

74. Rome: The Lateran Baptistery in the period of

Pope Hilarius (461-468)

(Temple, "Conversion and Political Expedience," 22)

75. Rome: Reconstruction of the Lateran Baptistery by

A. Lafréri, 1560.

(Krautheimer, Early Christian and Byzantine Architecture, 90)

76. Milan: The Baptisteries of the Episcopal Complex................. 167 (Edwards (Lewis), "Two Critical Aspects of Fourth-Century Architecture at Milan," 391 )

77. Rome: Old St. Peter's Basilica, begun 319-22

(Krautheimer, Early Christian and Byzantine Architecture, 55)

78. Single-naved cruciform churches, early $5^{\text {th }}$ century

(Lewis, "The Latin Iconography," 211)

79. Examples of baptisteries based on the Milanese model in northern Italy and France.

(Kostof, The Orthodox Baptistery of Ravenna, Fig. 128) 
80. Examples of baptisteries based on the Milanese model in northern... 175 (Kostof, The Orthodox Baptistery of Ravenna, Fig. 128)

81. Verona, aerial view of S. Stefano........................... 176 (http://www.verona.com)

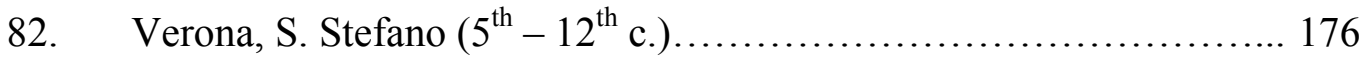
(http://www.verona.com)

83. Verona, S. Stefano (5 $5^{\text {th }}$ c.) 178 (Lewis, "The Latin Iconography," 211)

84. Verona, S. Stefano, lower ambulatory $\left(6^{\text {th }}\right.$ c. $)$ (Zovatto, "Arte Paleocristian a Verona," 582)

85. Verona, S. Stefano, upper ambulatory $\left(6^{\text {th }} \mathrm{c}\right.$. $)$ (Zovatto, "Arte Paleocristian a Verona," 583)

86. Verona, S. Stefano, crypt $\left(5^{\text {th }}-12^{\text {th }}\right.$ c. $)$ 180 (http://www.verona.com)

87. Vicenza: SS Felice e Fortunato, plan showing the small octagonal Baptistery and the chapel of Sta. Maria Mater Domini, c. 400

(Mackie, Early Christian Chapels in the West, fig. 22)

88. Vicenza: Cemeterial Stele of SS Felice e Fortunato (http://www.vicenza.com/temi/vicenza_sacra/chiese vicenza/felice fortunato.shtml)

89. Vicenza: SS Felice e Fortunato, interior nave and arcades $\left(5^{\text {th }}\right.$ c. $) \ldots 182$ (http://www.vicenza.com/temi/vicenza_sacra/chiese vicenza/felice fortunato.shtml)

90. Vicenza: SS Felice e Fortunato, west façade $\left(5^{\text {th }}\right.$ c. $) \ldots \ldots \ldots \ldots \ldots \ldots 182$ (http://www.vicenza.com/temi/vicenza_sacra/chiese_vicenza/felice_fortunato.shtml)

91. Vicenza: SS Felice e Fortunato, central nave mosaic $\left(5^{\text {th }}\right.$ c. $) \ldots \ldots \ldots 183$ (http://www.vicenza.com/temi/vicenza_sacra/chiese_vicenza/felice_fortunato.shtml)

92. Vicenza: SS Felice e Fortunato, Plan of the Chapel of Sta. Maria Mater Domini (after Arslan) $\left(6^{\text {th }}\right.$ c.)

(Mackie, Early Christian Chapels in the West, fig.22)

93. Vicenza: SS Felice e Fortunato, east façade showing the current semi-circular apse and campanile. (Pettinà, Giuseppe. Vicenza : con 146 illustrazioni e 1 tavola, Fot. 1.1. d'Arti Grafiche) 
94. Vicenza: SS Felice e Fortunato, wall mosaic from the chapel of Sta.

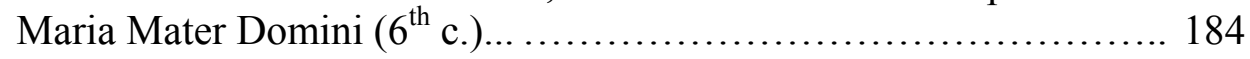
(http://www.vicenza.com/temi/vicenza_sacra/chiese vicenza/felice fortunato.shtml)

95. Padua : Plan of the Oratory of S. Prosdocimo..................... 185 (Mackie, Early Christian Chapels in the West, fig. 26)

96. Padua : Oratory of S. Prosdocimo, interior, apse. (Mackie, Early Christian Chapels in the West, fig. 77)

97. Padua : Oratory of S. Prosdocimo, Panel from sarcophagus 186 (Mackie, Early Christian Chapels in the West, fig. 29)

98. Padua : Oratory of S. Prosdocimo, dedicatory lintel (Mackie, Early Christian Chapels in the West, fig. 28)

99. Ravenna: Interior of the Neonian Baptistery $\left(5^{\text {th }}\right.$ c. $) \ldots \ldots \ldots \ldots \ldots \ldots . \ldots 188$ (Lowden, Early Christian and Byzantine Art, Fig. 64)

100. Ravenna: Site Plan of B. Ursiana and Baptistery

(Kostof, The Orthodox Baptistery of Ravenna, Fig. 10)

101. Ravenna: Ground plan of the Neonian Baptistery

(Kostof, The Orthodox Baptistery of Ravenna, Fig. 1)

102. Ravenna: The Neonian Baptistery, hollow tube construction of the cupola.

(Kostof, The Orthodox Baptistery of Ravenna, Fig. 31)

103. Ravenna: The Neonian Baptistery, isometric plan showing the original roof line and the cupola addition of Bishop Neon.... (Kostof, The Orthodox Baptistery of Ravenna, Fig. 8)

104. Ravenna: The Neonian Baptistery, level 2 plan (above the ground niches) $\left(5^{\text {th }} \mathrm{c}\right.$. $)$

(Kostof, The Orthodox Baptistery of Ravenna, Fig. 2)

105. Ravenna: The Neonian Baptistery, exterior view $\left(5^{\text {th }} \mathrm{c}.\right)$. (http://www.sacred-destinations.com/italy/ravenna-battistero-neoniano.htm)

106. Ravenna: The Neonian Baptistery, schema of the interior decoration, $\left(5^{\text {th }}\right.$ c.) (after Kostof)

(Kostof, The Orthodox Baptistery of Ravenna, Fig. 41)

107. Ravenna: The Neonian Baptistery, inscripted niche $\left(5^{\text {th }} \mathrm{c}.\right)$.... (http://www.sacred-destinations.com/italy/ravenna-battistero-neoniano.htm) 
108. Ravenna: The Neonian Baptistery, stucco relief $\left(5^{\text {th }}\right.$ c. $) \ldots \ldots \ldots \ldots \ldots 202$ (http://www.sacred-destinations.com/italy/ravenna-battistero-neoniano.htm)

109. Ravenna: The Neonian Baptistery, the arcade of Zone II $\left(5^{\text {th }}\right.$ c. $) \ldots \ldots .202$ (http://www.sacred-destinations.com/italy/ravenna-battistero-neoniano.htm)

110. Ravenna: The Neonian Baptistery, Zones III and IV of the mosaic

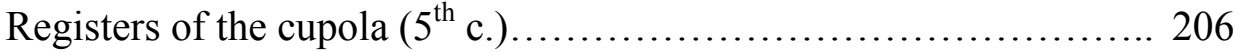
(http://www.sacred-destinations.com/italy/ravenna-battistero-neoniano.htm)

111. Ravenna: The Neonian Baptistery, Zone III, throne panel............ 206 (http://www.sacred-destinations.com/italy/ravenna-battistero-neoniano.htm)

112. Ravenna: The Neonian Baptistery, Zone IV and V, the Apostles of Christ and the Baptism of Christ............................. 209 (http://www.sacred-destinations.com/italy/ravenna-battistero-neoniano.htm)

113. Ravenna: The Neonian Baptistery, Sts. Peter and Paul ( $5^{\text {th }}$ c. $) \ldots \ldots \ldots 210$ (http://www.sacred-destinations.com/italy/ravenna-battistero-neoniano.htm)

114. Ravenna: The Neonian Baptistery, Zone V, the Baptism of Christ

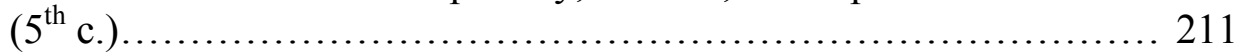
(http://www.sacred-destinations.com/italy/ravenna-battistero-neoniano.htm) 


\section{CHAPTER I}

\section{INTRODUCTION}

When we, Constantine Augustus and Licinius Augustus, met so happily at Milan, and considered together all that concerned the interest and security of the State, we decided...to grant to Christians and to everybody the free power to follow the religion of their choice, in order that all that is divine in the heavens may be favorable and propitious towards us and towards all who are placed under our authority.

- from a rescript issued at Nicomedia by Licinius, June $13,313^{1}$

From the time the Tetrarch Maximian made Milan his capital in 286 until the Emperor Honorius removed that imperial honor to Ravenna in 402, the city of Milan ${ }^{2}$ experienced a period of little more than a century of accelerating influence which extended its political and ecclesiastical hegemony across the area of Cisalpine Gaul that formed northern Italy, as well as Gaul, Spain, Illyricum and Rhaetia beyond the Alps. Although the city never enjoyed either the reverence or the loyalty that Rome inspired in its imperial residents, ${ }^{3}$ nor experienced the splendor of construction that Constantine

\footnotetext{
${ }^{1}$ William MacDonald, Early Christian and Byzantine Architecture (New York, NY: George Braziller), 1982, 11, citing Lactantius, De mortibus persecutorum, xlvii. MacDonald notes that this is all that is left of the Edict of Milan. Eusebius records a slightly different version in his Historia ecclesiae, X, v. 2 The Romans called Milan Mediolanum or Mediolanium (Suzanne Edwards (Lewis), "Two Critical Aspects of Fourth-Century Architecture at Milan: The Single-Nave Cruciform Basilica and the Palace Church.” Ph. D. diss., University of Michigan, 1964, 12). Archdale A. King suggests that the name is derived from the Celtic met lan, 'in the middle of the plain' (Archdale A. King, Liturgies of the Primatial Sees (London: Longmans, Green and Company), 1957, 288).

${ }^{3}$ The choice of the city as an imperial capital was largely a marriage of convenience, dictated by geography.
} 
lavished on Constantinople, for a short period of time the destiny of both the Empire in the West and the Western Church would be played upon the stage of Milan.

The extension of Milan's ecclesiastical hegemony was not only to have a lasting effect on the development of the Christian Church in northern Italy, but was pivotal in establishing the autonomy of that Church which, in this last period of late antiquity, began its long struggle to free itself from the imperial control that had protected and promoted its early development. That this was possible was due to several factors. In Milan, the Church acted not only as buffer between the emperor and the urban population, but its bishops, particularly in the latter half of the fourth century, established themselves as defenders of the people, a force of protection against the tyrannical (both political and theological) policies of the emperors. ${ }^{4}$ The early establishment of a well-developed episcopal hierarchy gave the bishops the opportunity to participate in all of the councils of the West ${ }^{5}$ and even in exile, they continued a subversive existence as a persistent force of theological orthodoxy. ${ }^{6}$ Among these bishops, Ambrose of Milan, whose tenure as bishop encompassed the last quarter of the fourth century (374-397), was pre-eminent.

Ambrose's episcopacy coincided with a period of decline of the Roman see. With the singular exception of the dynamic Pope Damasus (366-384), from whom Ambrose drew inspiration and support, ${ }^{7}$ the see of Rome suffered a series of weak popes who divided and diminished the see and were further hampered by the residuum of pagan

\footnotetext{
${ }^{4}$ Edwards (Lewis), "Two Critical Aspects of Fourth-Century Architecture at Milan," 58.

${ }^{5}$ Mark Humphries, Communities of the Blessed: Social Environment and Religious Change in Northern Italy, $A D$ 200-400 (New York: Oxford University Press, 1999), 51.

${ }^{6}$ Humphries, Communities of the Blessed, 49. Bishop Dionysius of Milan was exiled by Constantius II (along with Lucifer of Caligari and Eusebius of Vercelli) following the Council of Milan of 355 for their obdurate refusal to condemn Athanasius of Alexandria who was the pre-eminent pro-Nicene voice against the anti-Nicene (Arian) views of the emperor, Constantius II.

${ }^{7}$ Neil B.McLynn, Ambrose of Milan: Church and Court in a Christian Capital (Berkeley: University of California Press), 1994, 288.
} 
sentiment of the city's population, and especially, its aristocracy. ${ }^{8}$ But the bishop of Milan was uniquely poised, by his experience as an imperial civil servant, his proximity to the court, and, above all, the persistence of his orthodoxy to direct and determine the character of the Christian Church in northern Italy.

This thesis will argue that the architecture of the churches of northern Italy that were constructed during the fifth century reflected the influence and vision of Ambrose, bishop of Milan (374-397), whose spiritual authority, theologically and liturgically, militantly extended the ecclesiastical authority of the see of Milan. In particular, this thesis will demonstrate that the hegemony of Milan in northern Italy was reflected in the architectural accommodation of the distinctive Ambrosian liturgy of Milan, i.e., that form did indeed follow function. As such, this thesis will consider certain aspects of the liturgy (ceremony and chant, the sacramental liturgies of the Eucharist and baptism, and the cult of the saints) as requiring specific architectural accommodation.

To develop this argument, this thesis will adopt an integrated approach which initially weaves the disparate elements of the Christianization of northern Italy and the history of the imperial presence in Milan with the ecclesiastical history of the Milanese see and the personal elements of Ambrose's tenure as bishop. With the foundations laid, it will then examine the unique aspects of the Ambrosian liturgy which distinguish that rite from the Roman canon. Finally, this thesis will consider the architecture of Ambrose's own churches in Milan, constructed under his aegis as bishop, and make a comparative analysis of the architecture of the derivative foundations. To demonstrate the extensions of the influence of the Milanese see, these examples will be drawn (for the

\footnotetext{
${ }^{8}$ Edwards (Lewis), "Two Critical Aspects of Fourth-Century Architecture at Milan," 58. See Ambrose's measured and literary debate with the Roman senator Symmachus, leader of the pagan party in Rome.
} 
most part) from the district of Venetia, which is geographically far closer to Aquileia (the other great and ancient see of northern Italy) than to Milan. As much as possible, this thesis will draw on the writings of Ambrose, the literature of his contemporaries, and the patristic sources. 


\section{The Development of the Northern Italian Christian Communities}

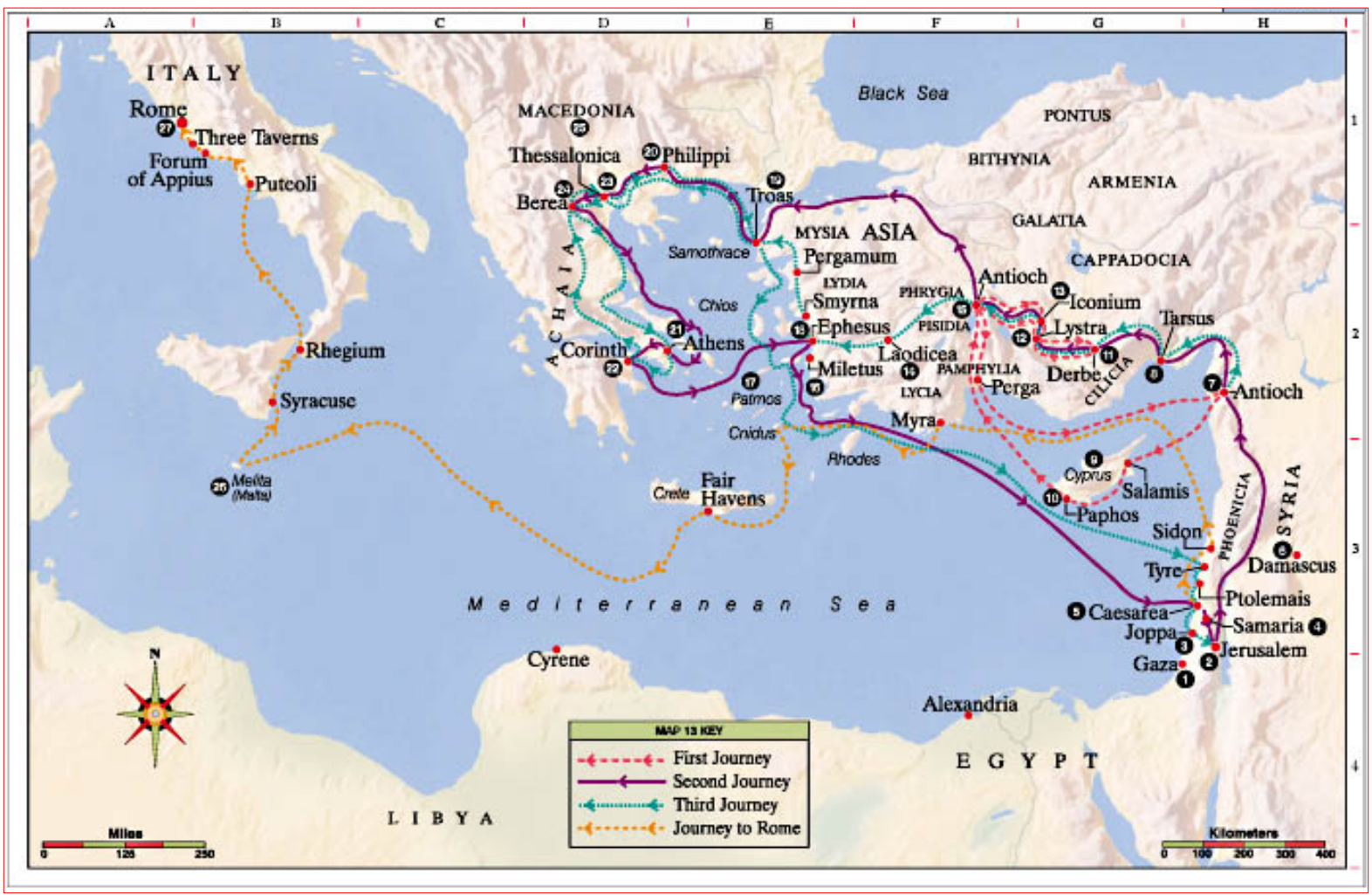

Figure 1: The Missionary Journeys of S. Paul

It is important to note that prior to the Emperor Constantine's recognition and protection of Christianity in 313 , the establishment of Christian communities in the western part of the Roman Empire, i.e. Italy, Gaul, Spain and North Africa, did not proceed uniformly. Certainly, in the first century and early half of the second century following the crucifixion of Jesus Christ, Christianity depended not only upon the vigor of the itinerant proselytizers, but also on the welcome and safety of the Jewish synagogue communities dispersed around the Mediterranean as a result of the destruction of the Temple in Jerusalem by the Romans in $70 .^{9}$ A look at the map of St. Paul's journeys during the apostolic period confirms the spread of the vibrant Christian communities in the eastern Empire, while the west lagged. Although Rome, as an imperial capital and

\footnotetext{
${ }^{9}$ Mark Humphries, Communities of the Blessed, 9.
} 
the site of Peter and Paul's martyrdom enjoyed early Christianization (as did, by extension, southern Italy), other factors determined the growth of Christian communities in northern Italy. There, Christian communities and Jewish communities became established concurrently, ${ }^{10}$ dependent largely on their proximity to the imperial hubs and the associated network of commercial, political, cultural and administrative linkages which enticed foreign visitors to residency. ${ }^{11}$

Geography cannot be entirely discounted. This area of northern Italy, i.e., the corridor between Milan and Aquileia, is defined as a rolling plain between mountains. To the north the region is bounded by the arc of the Alpine ranges, while the Apennines sweep diagonally from Liguria in the northwest to Rimini on the Adriatic to form the southern boundary. Of the two mountain range systems, it was the Apennines that proved to be the greater obstacle to human movement, forming a barrier that divided the societies and institutions of the southern portion of the Italian boot from the north. Even Genoa, positioned on the Tyrrhenian Sea well to the north, did not participate in the development of the northern central plain, but remained largely isolated by its position just below the narrowest point of the Apennine range. ${ }^{12}$ In 569, when the invading Lombards occupied the city of Milan, the bishop fled to Genoa, ${ }^{13}$ an indication of the effectiveness of the Apennine barrier.

The central Alps, with a number of negotiable passes, particularly in the area north of Verona (which follows the Adige River to Trento and the very ancient pass of

\footnotetext{
${ }^{10}$ Humphries, Communities of the Blessed, 9.

${ }^{11}$ Humphries, Communities of the Blessed, 9.

${ }^{12}$ Humphries, Communities of the Blessed, 24.

${ }^{13}$ King, Liturgies of the Primatial Sees, 289, 292. The bishops of Milan did not return to Milan until 649 (five successive bishops having died in Genoa).
} 
the Brenner) provided greater opportunities for movement and communication, and Celtic tribes were settled in the Po valley perhaps as early as the fourth millennium BCE. ${ }^{14}$ In the northeast, the Julian Alps had never proved to be a serious border, and the Venetic groups had long-standing ties with the Balkan and Hungarian peoples. ${ }^{15}$

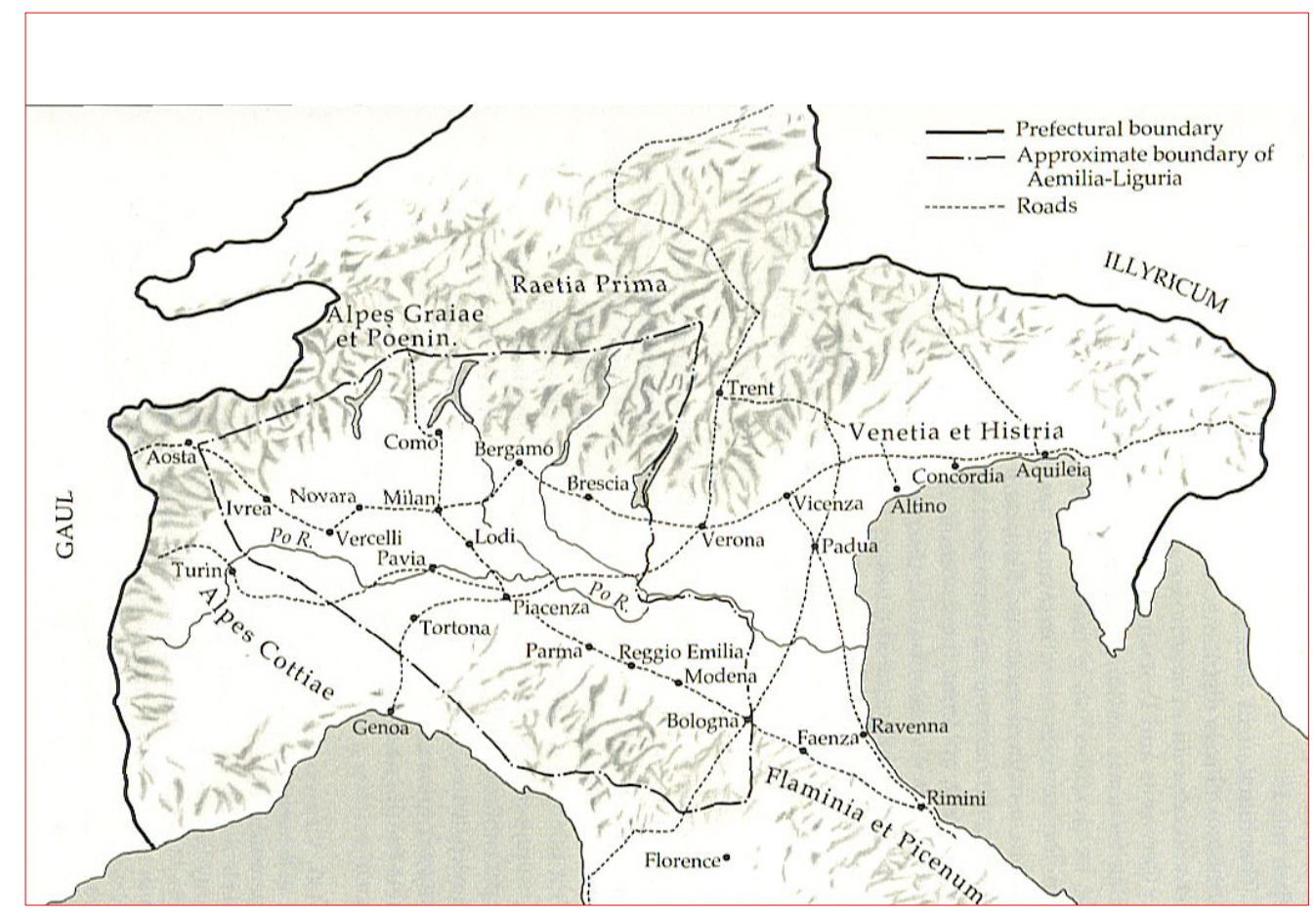

Figure 2: Northern Italy, showing the prefecture of Aemilia-Liguria and the road from Milan to Aquileia

Rome, in fact, did not actually penetrate the region until the third century BCE, with the foundation of Rimini and the laying of the Via Flamina. ${ }^{16}$ The roads followed the town settlements: the Via Aemilia connected Rimini to Piacenza (187 BCE), and the Via Postumia joined Genoa and Aquileia (148/7 BCE). Archeologically, Roman street grids can still be found in Bologna, Brescia, Como, Parma, Pavia, Piacenza, and

\footnotetext{
${ }^{14}$ Humphries, Communities of the Blessed, 27. Humphries cites L. Barfield, "The Iceman Reviewed," Antiquity 68 (1994), 10-26, for the speculation associated with the discovery of a mummified corpse in September 1991.

${ }^{15}$ Humphries, Communities of the Blessed, 27.

${ }^{16}$ Humphries, Communities of the Blessed, 27.
} 
Verona. ${ }^{17}$ However, during the first centuries of Christianity, a strong Roman presence did not necessarily guarantee a concomitant establishment of Christian communities. Culturally, these cities remained on the fringe of the Roman expansion across the Alps, and the growth of Christianity in the area was largely dependent upon local factors.

Economic factors played their part. The establishment of trade centers and the communication between them was enhanced as the Roman road network linked smaller towns to great ports, particularly those ports on the Adriatic, which included Rimini and Ravenna and the pre-eminent port city of Aquileia. Founded in $183 \mathrm{BCE}$, the port of Aquileia was ideally suited to enjoy not only the commerce of the Adriatic that promoted the success of Ravenna and Rimini, but the further access to the Balkans and the Danube. Sited on the river Natiso, ${ }^{18}$ which was navigable, the city was an agricultural and industrial center, ${ }^{19}$ and although its social linkages to the cities of Venetia are not clear, trade relationships must be inferred by virtue of the topography and short distances.

The region was well-watered, blessed with navigable rivers. In addition to the Adige of Verona, Padua had a port on the Medocus and smaller channels connected the cities of Oderzo, Concordia, Adria, and Vicenza to the Adriatic. ${ }^{20}$ The Po River was, of course, the most important of the waterways. Although it could be formidable when it flooded (still is, actually), its channels and tributaries made an expansive region smaller. It was possible to sail from Lake Garda to the Adriatic, via the Mincio and the Po. ${ }^{21}$

Even so, economics cannot tell the whole story of the development of Christian communities. That the establishment of these foundations was not necessarily linked

\footnotetext{
${ }^{17}$ Humphries, Communities of the Blessed, 28.

${ }^{18}$ Humphries, Communities of the Blessed, 26. The city actually lay sixty stades inland.

${ }^{19}$ Humphries, Communities of the Blessed, 32.

${ }^{20}$ Humphries, Communities of the Blessed, 26.

${ }^{21}$ Humphries, Communities of the Blessed, 26.
} 
only to trade networks is demonstrated by the instance of the development of the Christian communities of Lyons. Mark Humphries establishes the point that, were mercantile and commercial linkages the determining factor, then the Gallic port cities of Marseilles and Arles should have enjoyed earlier Christianization than did Lyons, much farther inland. But this, in fact, did not obtain. Lyons, as the effective capital of the Three Gauls with extensive imperial, social, and administrative systems in place, appears to have had Christian foundations that antedated either of the port cities. ${ }^{22}$

In point of fact, the literary and architectural evidence for the growth of Christian communities within the northern Italian corridor between Aquileia and Milan is slight. The signatories of the church councils show sporadic presence, and cannot be entirely trusted since the documents include only the signatures of those bishops not only in attendance but also in concordance, ${ }^{23}$ and therefore the absence of a bishopric from the

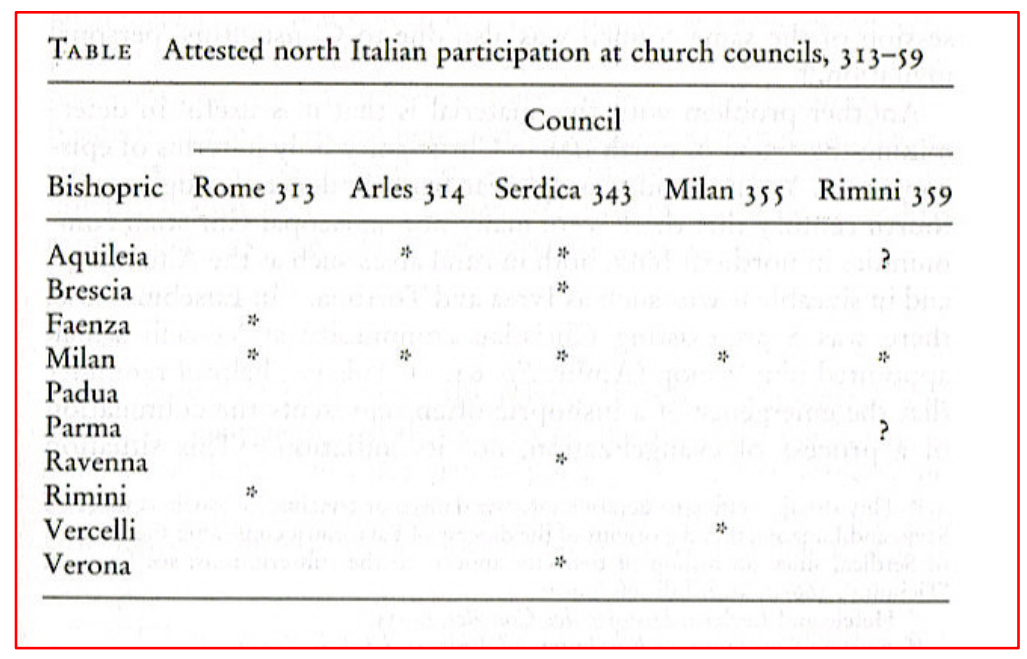

Figure 3: Northern Italian Conciliar Participation, 313-359

consiliar signatories is not conclusive. By the same token, the ecclesiastical lists of the individual bishoprics are also subject to judicious skepticism. The catalogs of bishops,

\footnotetext{
${ }^{22}$ Humphries, Communities of the Blessed, 9.

${ }^{23}$ Humphries, Communities of the Blessed, 9.
} 
often compiled in later centuries by scribes relying on oral traditions, or worse, manipulating the lists to enhance the venerability and sanctity of the bishopric, force the researcher to qualify most conclusions. As an example, the ecclesiastical list of Milan, which was both venerable and liberally endowed with saints, shows some rather glaring omissions. The Arian bishop Auxentius, who was appointed by Constantius II and held the see for nineteen years prior to the election of Ambrose, was removed from the list by his saintly successor, who judged the episcopacy of his heretic predecessor to have been invalid. ${ }^{24}$ Instead, Ambrose presents himself as the successor to Dionysius, the Milanese bishop exiled at the Council of Milan in 355 (Ambrose: Sermo contra Auxentius de basilicas tradendis, February or March, 386$).{ }^{25}$

To construe this selective editing cynically as conspiratorial is anachronistic and misses the point. The Late Antique/early medieval approach to the historicity of the ecclesiastical lists encompasses a continuum of intentions and motivations that frequently superseded the need for an accurate historical record. The towering personalities of the patristic period of early Christianity's dissemination represented far more to the medieval mind than we can divine without the context and vision of the Gospel of Jesus Christ reenacted and extended through His martyrs, saints, and early bishops. Having been incorporated into the circle of Christ's nearest and dearest, their influence and ability to control events extended far beyond their mere existence on earth. The association of a saint with a particular see was not only protective, it enhanced and elevated that see's importance. In the struggle for dominance and power, the stature of a see's patron,

\footnotetext{
${ }^{24}$ Humphries, Communities of the Blessed, 57.

${ }^{25}$ See note 157 below.
} 
particularly as associated with martyrdom or a direct apostolic connection, became a matter of far more significance than historical accuracy.

The history of St. Zeno, beloved patron of Verona, is an excellent case in point. Two literary sources form the basis of his hagiography: the Vita Zenonis by Coronatus (late eighth century) and an anonymous poem, Versus de Verona (ca. 800). Between them, St. Zeno was the founding bishop of Verona who "by his preaching brought Verona to baptism (Versus)," and he was also the eighth bishop of Verona (also from the Versus). His miracles include the curing of the Emperor Gallienus' daughter (Vita Zenonis) a century prior to his (Zeno's) birth and the averting of the floodwaters of the Adige River two centuries after his death. ${ }^{26} \mathrm{He}$ is called a "Confessor" ${ }^{\text {"27 }}$ by the Catholic Church, but there was a local tradition of martyrdom under the same Emperor Gallienus whose daughter he cured (a not exactly grateful response), which was recognized by Pope St. Gregory I. ${ }^{28}$ While it is clear that these different versions very likely represent different literary traditions, it is unlikely that the medieval believer would have considered the inconsistencies a problem. In the cosmos of St. Zeno's hagiography, all things were and are possible. And as patron of Verona, St. Zeno added immeasurable cachet to the bishopric. In the same manner, as will be seen below in the chapter devoted to the see of Milan, a late tradition added St. Barnabas to the episcopal Catalogus of

\footnotetext{
${ }^{26}$ Humphries, Communities of the Blessed, 67. The miracle occurred on October 17, 589. St. Zeno died in 380. In point of fact, the Adige River plays a significant part in the North African Zeno's story. He was known to be an avid fisherman and the iconography of the saint frequently includes a fishing pole and creel (The Catholic Encyclopedia Online, s.v. "St. Zeno," http://www.newadvent.org/cathen/15754d.htm (accessed March 7, 2008)).

${ }^{27}$ Following the Edict of Milan, martyrdom, the sacrifice of life and blood for Christ, was no longer required to validate the Christian faith. The Church recognized those individuals as "Confessors" who, by their exemplary lives of Christian saintliness and by their dedication to the faith, distinguished themselves and the Church..

${ }^{28}$ The Catholic Encyclopedia Online, s.v. "St. Zeno," http://www.newadvent.org/cathen/15754d.htm (accessed March 7, 2008).
} 
Milan. $^{29}$ As Humphries notes, there is a pattern which emerged of sees claiming apostolic foundation to enhance their prestige, and this creative approach to the history of the see was a reflection of the competition that existed between sees, particularly between the great sees of Rome, Milan, Aquileia and Ravenna, to draw on the holiness associated with an apostolic and martyrial tradition for jurisdiction, authority, and autonomy. ${ }^{30}$ As the age of martyrdom passed, this emerging pattern inspired the development of the cult of the saints in the latter half of the fourth century. The avidity with which sees pursued the relics of saints and martyrs, and the patronage dispensed by the great sees in sharing relics were logical extensions of the need to extend the hegemony of the see by deepening its claim to holiness. It was a strategy of which Ambrose of Milan made good use.

\section{Creative hagiography notwithstanding, by 350 at least twenty Christian} communities (beyond the meager ten bishoprics of the conciliar lists) can be identified in northern Italy. ${ }^{31}$ Aquileia was probably the most venerable of the sees, organized under its first bishop Hermagoras by the middle of the third century. ${ }^{32}$ Ravenna, Verona, Brescia and Padua were probably organized around the same time. ${ }^{33}$ The fact that most of the sites are within the Venetia and Histria provinces and close to the Adriatic coast

${ }^{29}$ Edwards (Lewis), "Two Critical Aspects of Fourth-Century Architecture at Milan," 452, Catalogus archiepiscoporum Mediolanensium.

${ }^{30}$ Humphries, Communities of the Blessed, 69.

${ }^{31}$ Humphries, Communities of the Blessed, 96: Aquileia, Bergamo, Brescia, Cremona, Faenza, Ivrea, Milan, Novara, Padua, Poreč, Pula, Ravenna, Rimini, Tortona, Treviso, Trieste, Vercelli, Verona, Vicenza, and Vrsar.

${ }^{32}$ Rita Lizzi Testa, "Christianization and Conversion in Northern Italy," The Origins of Christendom in the West, ed. Alan Kreider (Edinburgh: T \& T Clark), 2001, 50.

${ }^{33}$ Testa, "Christianization and Conversion," 51. Testa's dating of Christian communities in these cities is based upon epigraphic and literary references which identify the order of the consiliar signatories within the respective episcopal catalogues of the various cities. While local traditions can never be entirely discounted, Humphries has demonstrated that the both the consiliar signatories and the catalogues cannot be entirely trusted, as noted above. 
suggests that the spread of Christianity was from east to west (rather than north from Rome), ${ }^{34}$ and was a largely urban phenomenon. ${ }^{35}$

Not all of these cities had bishops, however. Rita Lizzi Testa notes that some of the early foundations remained under simple presbyterial administration well into the latter part of the fourth century. ${ }^{36}$ The Council of Serdica (343) had forbidden the foundation of bishoprics "in every village or town of little importance so that the name and authority of the bishop are not brought into disrepute." ${ }^{37}$ The Council hoped to promote the establishment of bishoprics on more than just religious considerations, i.e., the presence of military units, imperial visitation and residence, and commercial growth. In northern Italy, which had both strategic value and imperial presence, relatively large sees were organized around a saint bishop in Aquileia, Vercelli, Brescia and ultimately Milan. Within the district of Venetia, Verona was established as a bishopric; Vicenza and Padua appear to have had well-established Christian communities by the latter half of the fourth century, but the archeological and literary evidence is slight. ${ }^{38}$ Como, Pavia, and Piacenza awaited Ambrose for the installation of their bishops, but the vitality of their Christian establishments must be inferred in the construction of churches in the fifth century. ${ }^{39}$

\footnotetext{
${ }^{34}$ Humphries, Communities of the Blessed, 96.

${ }^{35}$ Testa, "Christianization and Conversion," The Origins of Christendom in the West, 49.

${ }^{36}$ Testa, "Christianization and Conversion," The Origins of Christendom in the West, 53. The Pastoral Epistles, which have been attributed to St. Paul but which are now dated to the second century, appear to accept a collegial relationship between bishops and the presbyterate. However, Ignatius of Antioch ( $c a$. 100-130) defined three distinct orders of the clergy in his epistles, of which the bishop was the spiritual leader and center, in a direct line of authority which proceeded from God and Christ. The monarchical episcopate made the bishop the supreme reference point of his own church; by the fourth century he was also the supreme civil authority in most communities as well.

${ }^{37}$ Testa, "Christianization and Conversion," The Origins of Christendom in the West, 55: Decree 6.

${ }^{38}$ Humphries, Communities of the Blessed, 85.

${ }^{39}$ Humphries, Communities of the Blessed, 85.
} 


\section{The Imperial Presence in Milan: Ecclesiastical Politics}

The encroachment of migratory tribes on the western boundaries of the Empire in the third and fourth centuries, and the revealed permeability of the Alpine barrier forced the western emperors to leave Rome and relocate their capitals north, to Trier, Lyons, Milan and Aquileia. As noted above, the imperial social and administrative networks spurred the development of Christian communities in the cities of the Milan-Aquileia corridor after the Edict of Milan was issued. Although the patriarchate of Aquileia was the more venerable see, having benefited from its proximity to Greece and the Adriatic, the see of Milan demonstrated an early leadership in promoting a well-developed episcopal hierarchy, as indicated by the persistent presence of its representatives at the western councils (Figure 3).

Nevertheless, it is impossible to consider the development of the northern Italian bishoprics and the architecture of their churches without the context of the imperial presence in the sees of Aquileia and Milan, and the relative interest in or indifference to ecclesiastical matters of the fourth century Augusti. The development of the northern imperial capitals had substantive political consequences, not only for the Empire, but also for the emerging hierarchies of the northern Italian Church.

In this context, Constantine, disturbed by the Donatist ${ }^{40}$ controversy in northern Africa and anxious to maintain Christian religious unity within his "unified" Empire,

\footnotetext{
${ }^{40}$ The Donatist heresy (named after Donatus Magnus, Bishop of Carthage) began in the Roman province of Africa c. 311 in the disorder following the persecutions of Christians by Diocletian (303-305). The Donatists refused to accept the authority to administer sacraments of those priests and bishops who had recanted their faith during the pogrom, particularly those individuals that were branded by the Church as traditor, those who had surrendered sacred texts to be publicly burned. This rigorous position was eventually extended to exclude sacramental authority to any priest of perceived impurity, calling into question the efficacy of the sacrament of penance in reconciling apostates and sinners to full membership in the Church. The heresy was condemned at the Council of Arles (314) and officially suppressed at the council of Carthage (411), but continued a sub rosa practice by the Christians of northern Africa until they
} 
invited the northern Italian bishops to the early Council of Rome in 313 but required them, as well as the Gallican bishops, to attend the Council of Arles in 314 (because the African bishops complained that the decisions of the earlier synod were inconclusive due to poor attendance). ${ }^{41}$

Donatism, however, was not the only threat to orthodoxy that the Church faced. The Church was confronted with a much more serious problem in the writings of the Alexandrian theologian Arius (250-336), who questioned the doctrine of the Trinity Though condemned by the Patriarch of Alexandria, Alexander, as heretical, the questions of the nature of the Trinity which Arius had raised resonated within the hierarchy of the Church, causing much debate (319). Still seeking a unified Church, the Emperor convened the First Council of Nicea in 325. The determinations of this council were left to the great holiness and inspiration of the bishops of the Apostolic sees of Asia, Palestine, Egypt, Greece, and Syria. With the exception of the Pope (who sent two representatives but did not attend), the western bishops included only Hosius of Cordova, Cecilian of Carthage, Mark of Calabria, and the Gallic bishop, Nicasius of Dijon. ${ }^{42}$ Of the 318 bishops that did attend, a small number ${ }^{43}$ were unable to subscribe to the canons of the Nicene Creed; these were exiled by Constantine, who viewed heresy as treason.

\footnotetext{
were subsumed by Islam in the seventh and eighth centuries. The Catholic Encyclopedia Online, s.v. "Donatists," http://www.newadvent.org/cathen/05121a.htm (accessed February 7, 2008).

${ }^{41}$ Humphries, Communities of the Blessed, 114.

${ }^{42}$ Catholic Encyclopedia Online, s.v. "First Council of Nicea," http://www.newadvent.org/cathen/11044a.htm (accessed March 3, 2008).

${ }^{43}$ The thirteen dissenting bishops were whittled first to seven, then to six, and finally to two. Catholic Encyclopedia Online, s.v. "Arianism," http://www.newadvent.org/cathen/01707c.htm, (accessed March 3, 2008).
} 


\section{Imperial Presence in Milan}

286: Maximian, co-emperor with Diocletian, establishes Milan as the imperial capital of the Western Empire.

305: Simultaneous abdication of Maximian and Diocletian.

313 -330: Constantine periodically in residence (issued Edict of Milan, decree of religious toleration which protected the Christian religion).

337: Death of Constantine, Constans I, emperor of the West.

363: Jovian, emperor of the West, returns to Milan.

364: Valentinian I, emperor of the West, moves his court from Milan to Trier.

\section{3/374: Accession of Ambrose as Bishop of Milan.}

375: Gratian becomes emperor of Gaul, Spain and Britain, his half-brother Valentinian II becomes emperor of Italy. Gratian alternates residence between Milan and Trier between 379 and 383, Valentinian II is in Sirmium.

350: Death of Constans I.

352 -361: Constantius II, emperor of the West, residence in Milan.

361: Death of Constantius, Julian the Apostate proclaimed emperor at Milan, moves to Sirmium (capital of Illyricum), Constantinople, and finally Antioch.

383: Gratian murdered in Paris, usurper Maximus seizes the capital of Trier, Valentinian II moves to Milan.

388: Maximus defeated by Theodosius who remains in Milan until 391 to guarantee the safety of Valentinian II who has moved to Trier.

391: Theodosius moves to Constantinople.

392: Death of Valentinian II, Eugenius attempts to usurp the Western Empire. Defeated by Theodosius in 394 who re-enters Milan.

395: Death of Theodosius, Honorius becomes emperor of the West.

\section{7: Death of Ambrose.}

402: Honorius moves the imperial capital to Ravenna.

Figure 4: Timeline of imperial residence in Milan 
The Arian heresy, which preoccupied the bishops and the councils of the Church from the end of the third century through most of the fourth century and beyond, proved to be the most divisive challenge that the early Church faced. Richard Krautheimer cogently distinguishes between the terms orthodox and Arian as representative of a continuum of interpretations, ${ }^{44}$ either agreeing with the canons of the Creed as established at the Council of Nicea in 325 (that Christ was consubstantial with the Father, the Greek homoousios) or disagreeing with the canons of the Creed, believing that the Son was only similar to the Father, but not consubstantial, neither sharing in the dignity of the divinity of God, nor co-eternal with him (homoiousios). ${ }^{45}$ As Krautheimer notes (rather wittily), the iota made all the difference. ${ }^{46}$ The extent of the debate over the nature of Christ's divinity within the hierarchies of the Church far transcended the initial schism caused by the writings of Arius, whose name became attached to the heresy. The recent scholarship associated with this subject prefers the terms pro-Nicene and antiNicene, ${ }^{47}$ or alternatively, the Christological debate. ${ }^{48}$

Constantine's support of the Nicene Creed was, oddly enough, ambivalent. His sister, Constantia, who believed that Arius was an injured man, recommended the heresiarch to the Emperor's leniency, who, impressed by his sister's deathbed concerns, had him recalled. ${ }^{49}$ Although Constantine forced Arius to subscribe to the canons of the

\footnotetext{
${ }^{44}$ Richard Krautheimer, Three Christian Capitals: Topography and Politics (Berkeley: University of California Press), 1983, 71 (my emphasis).

${ }^{45}$ Catholic Encyclopedia Online, s.v. "Arianism," http://www.newadvent.org/cathen/01707c.htm, (accessed March 3, 2008).

${ }^{46}$ Krautheimer, Three Christian Capitals. 71.

${ }^{47}$ Krautheimer, Three Christian Capitals and Daniel H. Williams, Ambrose of Milan and the End of the Arian-Nicene Conflicts (Oxford: Clarendon Press), 1995.

${ }^{48}$ Humphries, Communities of the Blessed. 115.

${ }^{49}$ Williams, Ambrose of Milan and the End of the Arian-Nicene Conflicts, 3. See Alan Kreider's essay, "Changing Patterns of Conversion in the West," The Origins of Christendom in the West, ed. Alan Kreider (Edinburgh: T \& T Clark), 2001, 17-21, for Constantine's ambivalences concerning his own conversion.
} 
Nicene Creed, he himself became enamored by the theology of the anti-Nicene faction, which through the machinations of Eusebius of Nicomedia had achieved political credibility with the Emperor. But in this, he was not alone. Although the eastern bishops had produced a creed to which they largely subscribed, the acceptance of the canons of the Creed continued to be problematic and deeply divisive. Daniel H. Williams notes that even Athanasius of Alexandria,${ }^{50}$ the pre-eminent proponent and most vigorous defender of the Nicene Creed, showed little inclination to use the term homoousios for nearly two decades after the Council. ${ }^{51}$ Exiled to the West by Constantine, protected by Constans in the West to be recalled by Constantine II, and exiled again by Constantius II, Athanasius did not begin to use the term as the watchword of orthodoxy until the publication of his treatise, De decretis in $352-353 .{ }^{52}$

Northern Italy, however, forming a tradition of orthodox practice which reflected the western Church's adherence to the Nicene Creed, was deeply influenced by the hounded Athanasius. As Humphries notes, at least four of the five northern Italian bishops who signed the defense of Athanasius at the Council of Serdica in 343 knew him personally from his sojourns in Italy. ${ }^{53}$ It is, therefore, significant that when the Arian controversy invaded the diocese of Italie, it was through the imperial family, and not through the bishops, who had been largely excluded from the Christological debate. The Emperor Constantius II, in residence in Milan (now de facto capital of the Western

\footnotetext{
${ }^{50}$ Athanasius was present at the First Council of Nicea as a deacon attached to the Patriarch Alexander. It is his count of the attending bishops which the scholarship considers definitive. He was Alexander's designated successor to the Patriarchy of Alexandria, and remained very popular with his constituency despite the fact that he spent most of it in exile. Absence, as has been said, makes the heart grow fonder, but it is more likely that his political value, as a patriarch in opposition to the imperial family, endeared him to his see.

${ }^{51}$ Williams, Ambrose of Milan and the End of the Arian-Nicene Conflicts, 15.

${ }^{52}$ Williams, Ambrose of Milan and the End of the Arian-Nicene Conflict, 15.

${ }^{53}$ Humphries, Communities of the Blessed, 128. The bishops of Verona, Brescia, Milan, and Aquileia.
} 
Empire), convened the Council of Milan in 355; the main item on the agenda was the condemnation of the stubborn Athanasius, now Patriarch of Alexandria, whom the staunchly pro-Arian Constantius perceived as a threat to the unity of the Church and by extension, the stability of the empire. ${ }^{54}$ He then installed the anti-Nicene bishop Auxentius as his metropolitan in Milan (replacing Bishop Dionysius, who joined Eusebius of Vercelli and Lucifer of Cagliari in exile following the craven accession of Pope Liberius and Fortunatianus of Aquileia to the demands of the Emperor at the council). ${ }^{55}$

Auxentius, a Cappadocian, proved to be a tenacious and adroit opponent for the pro-Nicene faction. As a diplomat and a theologian, he was both flexible and clever, and was able to establish a symbiotic relationship with the imperial family that permitted him to successfully manage his see for nineteen years. It was not for want of trying that the pro-Nicene party failed to dislodge him. During the incumbency of the Emperor Julian (the Apostate), an emperor who took no interest in the internal dissensions in the Church, synods in Gaul, Spain, and Italy unanimously anathematized him and the heretical Illyrian bishops, but Auxentius, well-protected by the imperial family, remained in place. ${ }^{56}$ Two serious attempts to dislodge him occurred under the Emperor Valentinian I; both failed. ${ }^{57}$ One of these, which was mounted by Hilary of Poitiers in 364 , is an indication of the slippery nature of Nicene disputes (and, incidentally, the urbanity and sophistication with which Auxentius deflected the challenge). Hilary, who later wrote of

\footnotetext{
${ }^{54}$ Humphries, Communities of the Blessed, 129.

${ }^{55}$ Williams, Ambrose of Milan and the End of the Arian-Nicene Conflict, 58. Both Liberius and Fortunatianis had acted as hosts to Athanasius during his exile. The emperor's banishment of Dionysius of Milan, Eusebius of Vercelli, and Lucifer of Caligari was sufficiently intimidating to inspire their reevaluation of the man who had relied upon their support.

${ }^{56}$ Williams, Ambrose of Milan and the End of the Arian-Nicene Conflict, 77.

${ }^{57}$ Williams, Ambrose of Milan and the End of the Arian-Nicene Conflict, 77.
} 
the episode in Contra Auxentium, accused the bishop of Milan of heresy, which required that the bishop answer his accuser at an inquest; Hilary himself came to Milan to defend his accusation. But Auxentius was able to offer an ambiguous statement which the tribunal of ten bishops could characterize as neither Nicene nor anti-Nicene and therefore Hilary's assertion that the bishop of Milan was attempting to deceive the tribunal was not convincing. Auxentius further portrayed himself as a deeply injured man, sensitive to both the concerns of his flock and to the need to maintain the public peace. ${ }^{58}$ The Emperor, Valentinian I, who was normally uninterested in the theological bickering of bishops, was not amused by the prospect of bishops disturbing the public peace and Hilary was ordered to leave Milan.

Neil McLynn notes that the scholarship which has considered the tenure of Auxentius in Milan often portrays him as an outsider, the Greek-speaking Cappadocian who never learned to communicate with his flock. But this characterization came from Athanasius, a biased recorder. ${ }^{59}$ And in fairness to the bishop, it should be noted that Christian liturgy, which was still in a state of becoming in the West,${ }^{60}$ began in Greek and only slowly changed to Latin usage, nor was the change accepted uniformly.

Auxentius was bishop of Milan for nineteen years, an ostensibly serene and secure Arian incumbent who managed his see as a steady captain of the ship while the seas of disturbance and pro-Nicene sentiments of northern Italy's orthodox bishops and congregations swirled around but did not damage him. But when he died in $374,{ }^{61}$ there

\footnotetext{
${ }^{58}$ Williams, Ambrose of Milan and the End of the Arian-Nicene Conflict, 79.

${ }^{59}$ McLynn, Ambrose of Milan, 20 (Athanasius, Hist. Ar. 75).

${ }^{60}$ See Paul F. Bradshaw, "The Effects of the Coming of Christendom on Early Christian Worship," The Origins of Christendom in the West, ed. Alan Kreider (Edinburgh: T \& T Clark), 2001, 276-282 who notes that formulaic liturgical practice coalesced in the fourth century.

${ }^{61}$ The dating of Auxentius' death is tied to the date of Ambrose's accession, about which the scholarship is not in agreement. See note 94 .
} 
is every indication that the strong central core of orthodoxy among the people of Milan and the bishops of northern Italy did not intend to allow an anti-Nicene replacement. The theologically indifferent Valentinian was not an emperor to define doctrine as Constantius II had done; vis à vis the imperial family, the moment of opportunity had arrived. 


\section{CHAPTER II}

\section{AMBROSE OF MILAN}

Ambrose of Milan was born in the imperial capital of Trier (Trèves) on the Moselle River in Gaul, ca. 339. His family, the Aurelii, was a distinguished Roman family, ancient both in Roman lineage and in their conversion to Christianity; they numbered at least one martyr, the virgin Soteris. ${ }^{62}$ Ambrose was the youngest child of the Praetorian Prefect of the Gauls, Aurelius Ambrosius. As a high-ranking civil servant, his administrative responsibilities stretched across the modern countries of France, Spain, Portugal, parts of Germany, Britain, Sardinia, Corsica, and Sicily. ${ }^{63}$ There is only one reference to Ambrose's childhood, recorded by Paulinus: ${ }^{64}$ while in his cradle in the garden, a swarm of bees alighted on the baby's mouth. ${ }^{65}$

Ambrose had an older sister, Marcellina, who received the veil of perpetual virginity from Pope Liberius, ${ }^{66}$ and an older brother, Uranius Satyrus. He was close to

${ }^{62}$ F. Homes Dudden, St. Ambrose, His Life and Times (Oxford: Clarendon Press), 1935, 2.

${ }^{63}$ Dudden, St. Ambrose, 2.

${ }^{64}$ Boniface Ramsey O.P., Ambrose (London and New York: Routledge), 1997, 195. Paulinus, Deacon of Milan, served the bishop as amanuensis and scribe. His Vita Ambrosii was written as a result of Augustine's encouragement, whom he met when he moved to Africa following the death of Ambrose in 397. Most scholars assign its composition to the period 412-413, some as late as 422 .

${ }^{65}$ Dudden, St. Ambrose, 3, citing Paulinus, Vita Ambrosii, 3, and Cynthia Hahn, "Narrative on the Golden Altar of Sant'Ambrogio in Milan: Presentation and Reception," Dumbarton Oaks Papers, 53, 1999, 171. This incident was, of course, incorporated into Ambrose's hagiography as his first miracle, with the addition that the bees deposited honey in the child's mouth, an addition inspired by his name. As a familiar topos, the same story is told of other gifted orators: the infants Pindar, Hesiod, and Plato also experienced the acclamation of bees.

${ }^{66}$ Dudden St. Ambrose, 3. 
both his siblings; ${ }^{67}$ Marcellina lived within the family home for many years, and Satyrus joined Ambrose in Milan after his election to the episcopacy as his assistant for temporal affairs, ${ }^{68}$ which included providing domestic support for the episcopal residence to free Ambrose for his duties as bishop and the management of the family properties. Although Ambrose had surrendered these properties to the Church, ${ }^{69}$ he and Satyrus apparently retained the responsibility for their management. It was an extraordinary sacrifice for the older brother to make, one which eventually cost him his life. ${ }^{70}$

Both Satyrus and Ambrose received instruction in the Christian faith through the presbyter (priest) Simplician, ${ }^{71}$ but since they were both destined for secular careers, they were not baptized, but remained catechumens. This was not unusual at this time in the history of the early Church. For adults, the cleansing of sin by baptism was a serious affair, and post-baptismal lapses into sin were therefore that much more serious. ${ }^{72}$ Augustine, writing in his Confessions expressed it very well: “...because, if I lived, I should inevitably get defiled again, and sin after baptism is of a deeper dye and fraught with greater danger to the soul than sin before it" (Augustine: Confessions i. 11). ${ }^{73}$

\footnotetext{
${ }^{67}$ Dudden, St. Ambrose, 3. The three letters that we have of Ambrose to his sister validate this assertion; they offer the most intimate view that we have of the future saint. One of them is addressed "To the lady his sister, dearer than life and eyes, a brother." (Ambrose, Epistolae, xx, June 386)

${ }^{68}$ Dudden, St. Ambrose, 107.

${ }^{69}$ McLynn, Ambrose of Milan, 70. The surrender of the family properties to the Church left Satyrus with no option but to join Ambrose, since they held their patrimony in common. Marcellina had relinquished her portion for the usufruct upon Ambrose's accession, which allowed her to be assured of her own financial security in the event that Ambrose pre-deceased her, but reassured the Milanese that she would not alienate the assets for personal reasons.

${ }^{70}$ McLynn, Ambrose of Milan, 71. The financial pressure on the brothers increased once Ambrose began his ambitious program of church construction. Satyrus, returning from northern Africa where he had gone to litigate the Ambrosian rights to a piece of property, became ill in Rome. After praying at the tomb of St. Lawrence, he recovered his strength sufficiently to return to Milan, where he died in his brother's arms. Ambrose was deeply affected by the loss of his brother; in his eulogy for Sartyrus, his grief transcends the panegyric of Roman funeral oration. (Ambrose, De excessu fratris)

${ }^{71}$ Dudden, St. Ambrose, 57. Simplician also joined Ambrose in Milan, succeeded him as bishop, and was also canonized.

${ }^{72}$ Dudden St. Ambrose, 58.

${ }^{73}$ Dudden, St. Ambrose, 322.
} 
Constantine's deferral of baptism until his deathbed is an example of an approach that accepted certain pragmatic realities associated with emperorship.

Both brothers were educated as lawyer and civil servants. In the spring of 368 , Ambrose was appointed assessor by the praetorian prefect Petronius Probus, an immensely wealthy man who extended his patronage to both Ambrose and Satyrus. This was to be a turning point in the brothers' careers as civil servants and $c a$. 370 , both brothers were promoted to provincial governorships. Ambrose was appointed as governor of Aemilia-Liguria. $^{74}$

Constantius II's "foxy old Arian" ${ }^{75}$ bishop Auxentius died in 374 while the reigning emperor, Valentinian I, was in Trier. The absence of the Emperor provided an opportunity for the orthodox population of Milan to elect a pro-Nicene bishop. Equally determined, the Arian party (which included the remnants of Auxentius' clergy and those elements of the imperial court that were in residence in Milan) expected to retain the see. Fearing violence, the governor, Ambrose, went to the cathedral to defuse a potentially violent confrontation. Rufinus of Aquileia wrote an account of Ambrose's dramatic election for Bishop Chromatius of Aquileia. ${ }^{76}$ It is worth excerpting since it became the official version of the Milanese church, recorded almost verbatim by Paulinus of Milan, Ambrose's scribe and biographer: ${ }^{77}$

When Auxentius, the bishop of the heretics at Milan, had died, the people of the two parties clamorously supported their different claims. The grave dissension and dangerous unrest of the parties threatened to produce immediate destruction for their own city if they failed to fulfill their mutually contradictory aims. Ambrose was at that time governing the province. When he saw the disaster that

\footnotetext{
${ }^{74}$ Dudden, St. Ambrose, 61

${ }^{75}$ Dudden, St. Ambrose, 187.

${ }^{76}$ McLynn, Ambrose of Milan, 2-3. Ambrose consecrated Chromatius when he was raised to the altar of Aquileia.

${ }^{77}$ McLynn, Ambrose of Milan, 3.
} 
lay in store for the city, he hastened, in accordance with his rank and duties, to enter the church, to calm the disturbance among the people. When he had there concluded a long speech, in accordance with the laws and with public order, a shout and a single cry suddenly arose among the people who were fighting and quarreling among themselves: "Ambrose for bishop!" They shouted that he should be baptized immediately (he was a catechumen) and be given to them as bishop, and that there was no other way that they could become a single people sharing a single faith, unless Ambrose were given to them as bishop. Although he demurred and resisted fiercely, the desire of the people was referred to the emperor and the order came to implement it with all speed. For the emperor said that it was thanks to God that this sudden conversion had restored the divided beliefs and antagonisms of the people into a single shared consensus and inspired a unanimous proposal. Shortly afterwards, Ambrose obtained the grace of God and was both initiated in the sacred mysteries and made bishop.

\section{(Rufinus, Historia Ecclesiastica, ii, 11)}

The hagiography of St. Ambrose notes the tradition that it was a child's voice that first spoke up. $^{78}$

Of equal interest are Ambrose's attempts to evade this election. ${ }^{79}$ Leaving the assembly expeditiously, he proceeded to his court of justice where he ordered the torture of some prisoners in his capacity as governor. ${ }^{80}$ When this show of cruelty failed to impress the crowd who had followed him to the court (they shouted 'Your sin upon our

\footnotetext{
${ }^{78}$ Dudden, St. Ambrose, 66.

${ }^{79}$ Dudden,. St. Ambrose, 71.The patristic period of the history of the Church is littered with unwilling prelates. Dudden mentions Cornelius (Rome, 251), who "suffered violence so as to receive the episcopate by compulsion," Cyprian, who tried to hide, St. Basil's successor, Eusebius, who neither wanted the office nor were the people willing to have him - imperial troops were needed to compel him to don the mitre. St. Martin of Tours was tricked out of his monastery by a stratagem, hid in a barn, and was escorted under armed guard to his consecration. St. Augustine of Hippo, whose career appears to have been characterized by a systemic reluctance to move on to the next step, was apparently seized by the people, dragged before the bishop, and despite his tears, ordained a priest. Ambrose himself threatened Gaudentius of Brescia with withdrawal of communion if he did not return from his sojourn of study in the East to accept his consecration as bishop of Brescia (Gaudentius, Serm. xvi), a peculiar turn since Ambrose complained that he was "snatched into the priesthood from the magistrate's tribunal and my robes of office (De officiis, i. 4)." (McLynn, Ambrose of Milan, 1).

${ }^{80}$ McLynn, Ambrose of Milan, 45. A contemporary papal decretal excluded magistrates from the priesthood, on the grounds of the need to use torture in the course of their duties: "immunes a peccato esse non posse manifestum est. Dum einim et gladius exeritur aut iudicium confertur iniustum aut tormenta exercentur pro necessitate causarum..." (Siricius, Epistolae, 10.5). Within the period of Ambrose's elevation in 374 and the papacy of Celestine I (422-432) this changed as bishops were increasingly drawn from the ranks of the magistracy (see note 112).
} 
heads!'), ${ }^{81}$ he returned to his lodgings and invited some prostitutes to spend the afternoon with him (Paulinus, of course, discounts this part of the story as strictly for show). ${ }^{82}$ Again the crowds shouted, "Your sin upon our heads!"

McLynn has serious reservations about the spontaneity of Ambrose's election. Noting that until recently scholars had discounted the account of Ambrose's election by Rufinus and Paulinus as hagiographical, McLynn accepts the account on its face value. ${ }^{83}$ Instead, he questions both the level of discontent within the pro-Nicene community, which he suggests was minimal, and the extent to which Ambrose himself had aligned himself with a core pro-Nicene faction to manipulate the election of a pro-Nicene bishop. That this election resulted in his own elevation occurred as a result of a critical mistake that Ambrose had made: in presenting himself to the election congregation in the full panoply of imperial authority, he either inadvertently or (more cynically) purposely instigated the riot that ensued between the pro-Nicene and anti-Nicene congregations, of which he rapidly lost control. As an imperial governor, Ambrose now found himself in the invidious position of having to explain to the emperor his inability to maintain the peace in the capital of Milan, and he was now hard-pressed to provide a series of events which made the election of the imperial governor to the bishopric both inevitable and inescapable.

Ambrose's next actions confirm for McLynn his thesis that Ambrose's election as bishop was part of a monumental charade to manipulate the election. That night, he

\footnotetext{
${ }^{81}$ McLynn, Ambrose of Milan, 44, citing Paulinus, Vita Ambrosii, 7.1.

${ }^{82}$ McLynn, Ambrose of Milan, 45.

${ }^{83}$ McLynn, Ambrose of Milan, 44. Paulinus' account has been largely accepted, on the basis that his story provides too much damaging material against the saint, or at least, is too clumsily written to provide a basis to allow "pious disquisitions upon their typological significance." In what might be called a reverse validation, Paulinus' Vita of Ambrose may be characterized as conscientious, but hardly sophisticated.
} 
attempted to leave Milan, hoping to flee to Pavia. In the dark, he mistook the road, and spent the night circling the city, a peregrination that McLynn finds incredible. ${ }^{84}$ The next morning, he was discovered, weary and beaten, at the Porta Romana (which McLynn notes trenchantly was the adventus gate used by the emperor in entering the city - the main triumphal route) and taken into custody by his future congregation. McLynn writes: "The spectacle of the governor humbled by capture, but also exalted by the divine intervention which had thwarted his plans, could hardly fail to provoke curiosity and baffle criticism." 85 Ambrose was now placed under house arrest by his future congregants, while a relatio was sent to Valentinian which claimed that the Christians of Milan would not be 'one people and one faith' unless Ambrose was their bishop. ${ }^{86}$ Valentinian's rescript, attributing the people's 'sudden conversion' to the will of God, is preserved in the records of the see as a certificate of Ambrose's legitimacy. ${ }^{87}$

McLynn's thesis appears to be based upon a careful reading of circumstances that are not present in the literature (e.g., an independent account of the restiveness of the proNicene faction which would have required the governor's presence), and an understanding of pro-Nicene/anti-Nicene ecclesiastical politics. From council to council, and from bishop to bishop, the maneuvering of the factions seems to have represented the fourth century's answer to the modern day soap opera, often involving non-ecclesiastical claques and less-than-ethical subterfuges. He notes that Athanasius was able to secure his election as Patriarch of Alexandria through the use of a forged letter to Constantine

\footnotetext{
${ }^{84}$ McLynn, Ambrose of Milan, 46. "It is difficult to accept that this was simply bad luck and that Ambrose was making a genuine bid to escape."

${ }^{85}$ McLynn, Ambrose of Milan, 47. One does not take the road to Pavia from the Porta Romana.

${ }^{86}$ McLynn, Ambrose of Milan, 48. Valentinian I is an instance of an "indifferent" emperor: he deliberately refrained from interfering in ecclesiastical business. In this instance, however, his concurrence was required because Ambrose was a high-ranking government official. Valentinian was delighted with the people's choice, which he believed reflected on his good judgement in promoting Ambrose to high office. ${ }^{87}$ McLynn, Ambrose of Milan, 48.
} 
alleging the will of the koinon, and that Constantine's dismissal of Ibas of Edessa was effected through the efforts of a small minority faction. ${ }^{88}$

Nevertheless, certain other realities militate against an indictment of Ambrose as promoting himself to the altar of Milan through intrigue. At the age of thirty-four, he had achieved remarkable success in his civil career, rising to the status of provincial governor, enjoying the patronage and promotion of a wealthy and influential man, and the confidence of an emperor (in De officiis i.4, he notes that he was devoted to the "vanities of the world'). ${ }^{89}$ More importantly, within Milan were those anti-Nicene bishops who had come to attend Auxentius' death and burial and, presumably, support the clergy in place with a suitable candidate to replace Auxentius. From them, we hear nothing, ${ }^{90}$ although it was immediately made clear to them that Ambrose would be a pro-Nicene bishop, having extracted the promise from the emperor that he would be baptized, ordained and consecrated by a 'catholic,' i.e., orthodox, bishop. This was assured once the emperor approved the election. ${ }^{91}$

I think it is very likely that Ambrose was in communication with a determined faction of the pro-Nicene party that viewed the death of Auxentius as an opportunity to recover the see of Milan, but that his own candidacy was deeply shocking to him, the result of circumstances beyond his control. His attempts to extricate himself are like the

\footnotetext{
${ }^{88}$ McLynn, Ambrose of Milan, 48.

${ }^{89}$ McLynn, Ambrose of Milan, 1.

${ }^{90}$ Testa, "Christianization and Conversion," The Origins of Christendom in the West, 60-61. Testa notes that information on the anti-Nicene sees is almost non-existent, offering as examples the see of Rimini (chosen by Constantius II as the site of a council, which indicates that it was a see of some importance), the see of Parma, and, for that matter, the see of Milan between 355-374, the tenure of Auxentius. Her inference is that the literature of the anti-Nicene bishops was deliberately suppressed in the sweep of the triumph of orthodoxy following Ambrose's election, just as Ambrose himself deleted Auxentius from the Milanese Catalogus.

${ }^{91}$ Dudden, St. Ambrose, 68. He was consecrated by the Bishop of Aquileia. Dudden notes that Ambrose received this assurance from Valentinian in the rescript which he sent validating the election. McLynn does not refer to this clause, one way or the other, but infers that Ambrose initially refused consecration by the bishops in place (McLynn, Ambrose of Milan, 51).
} 
futile thrashing of a bird in a net, struggling to escape. In later years, and for various purposes, Ambrose would return to the circumstances of his election, and at times, it appears to be habitual rubbing of an old wound. On one occasion, he chastized his congregation with their responsibility in the election ("You are my fathers and mothers...") (Ambrose, Expositio evangelii secundum Lucam, viii.73) and in writing about the qualities necessary for a bishop, we have the sudden exclamation: "How I resisted being ordained!" (Ambrose, De poenitentia, ii. 72). ${ }^{92}$ Writing to Valentinian II in 386 , he reminded the young emperor that the people had elected him and had promised peace if he would accept the episcopate (Ambrose, Epistolae, 77, xxi. 7) ${ }^{93}$

Within the week, he was baptized and confirmed, and proceeding through the church offices of doorkeeper, reader, exorcist, acolyte-subdeacon, deacon, and presbyter, was consecrated bishop on the first (seventh) of December, 373 (374) ${ }^{94}$ Paulinus recording, "ordinatus est summa gratia et laetitia cunctorum" (Paulinus, Vita Ambrosii, 9. 3). ${ }^{95}$ McLynn attributes this grossly accelerated progress from catechumen to bishop as necessary to acquaint Ambrose with each of the various clerical groups of the see and to provide 'liturgical momentum' for his consecration. ${ }^{96}$ It was, ironically enough, a flagrant violation of the second Nicene canon which prohibited ecclesiastical promotion without a reasonable apprenticeship within the ranks. This ideal, while not specific as to

\footnotetext{
${ }^{92}$ McLynn, Ambrose of Milan, 1.

${ }^{93}$ McLynn, Ambrose of Milan, 47.

${ }^{94}$ Dudden, St. Ambrose, 74. There has been some dispute among historians as to whether the year was 373 or 374 , the latter date generally preferred. Nor is the scholarship united on the day of the election of Ambrose. The two biographical sources for this paper are an example of the disagreement. Dudden accepts Paulinus of Milan's account that the year was 373, which is also indicated in the Chronicle of Jerome, but disputes the date of 7 December (St. Ambrose's feast day), preferring 1 December. McLynn, citing O. Faller, "La data della consacrazione vescovile di Sant' Ambrogio," Ambrosiana (1942), 97-112, opts for December 7, 374.

${ }_{95}^{5}$ McLynn, Ambrose of Milan, 51 "He was ordained with the utmost grace and rejoicing among everyone."

${ }^{96}$ McLynn, Ambrose of Milan, 51.
} 
time and duration, was certainly based on the imperial model of civil service. ${ }^{97}$ As Dudden notes, the ideal is limned in its notable exceptions. Augustine, Origen, Jerome, and Paulinus of Nola were all ordained to the presbyterate without serving in the interim offices, the layman Fabian was elected pope upon the death of Pope Anteros (256) when a dove happened to alight on his head, ${ }^{98}$ and there are instances of individuals who were neither baptized nor particularly distinguished by the uprightness of their lives who were promoted to ecclesiastical office. Two egregious examples are Nectarius, who was nominated to the bishopric of Constantinople by Theodosius (381), and Synesius, who was described as a 'sporting country gentleman and philosopher,'99 qualities which did not prevent his elevation as bishop of Ptolomais in 409. Jerome, that ever persistent voice from the desert, observed, "One who was yesterday a catechumen is today a bishop; one who was yesterday in the amphitheatre is today in the church; one who spent the evening in the circus stands in the morning at the altar; one who a little while ago was a patron of actors is now a dedicator of virgins (Jerome, Epistolae, 1xix. 9)."

Interestingly enough, the episode of Ambrose's flight from Milan, attempting to escape the Divine Will of God by running away, became an important part of Ambrose the saint's hagiography, played out in the iconography associated with the saint. Cynthia Hahn has analyzed the political rhetoric which is embodied in the iconography of the

\footnotetext{
${ }^{97}$ Dudden, St. Ambrose, 72.

${ }^{98}$ Dudden, St. Ambrose, 72. Actually, the Catholic Church to this day does not require ordination as a prerequisite for a bishop or a pope, only baptism and confirmation in the Church, and, of course, they must be MALE. See note 189 for a notable example of a non-ordained bishop associated with the see of Milan.

${ }^{99}$ Dudden, St. Ambrose, 73.

${ }^{100}$ Dudden, St. Ambrose, 73.
} 
saint as associated with the ninth century ${ }^{101}$ golden reliquary altar of Ambrose's first foundation, the Basilica Martyrum (the Ambrosiana, now known as Sant'Ambrogio). ${ }^{102}$

This altar, in which St. Ambrose is entombed (with the martyr saints Gervasius and Protasius), is constructed in its entirety, front and back, ${ }^{103}$ with gold and silver panels

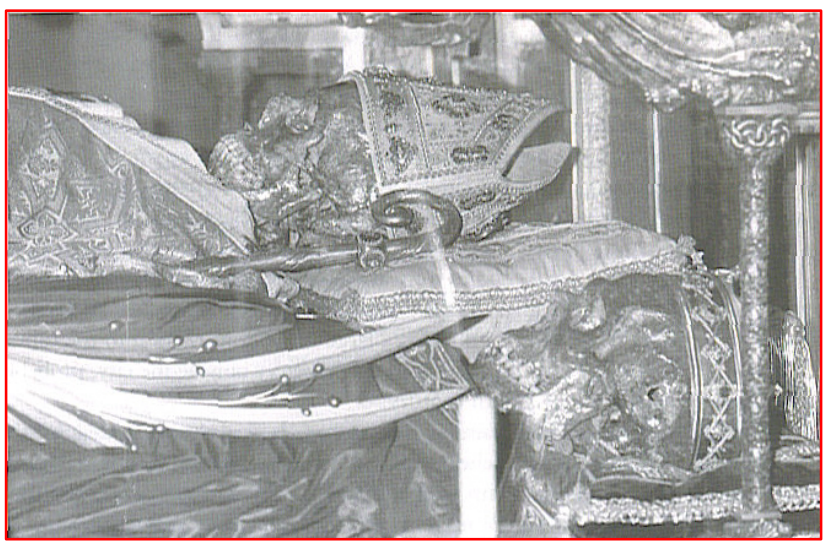

embellished with gems and enamels.

The front of the altar, facing the congregation, has twelve panels of gold repoussé which tell the story of the life of Christ, with particular emphasis on the Passion. The back

Figure 5: Milan, S. Ambrogio. The body of St. of the altar, which would be visible to Ambrose between SS Gervasius and Protasius

the liturgical celebrant, has panels

showing the life of Ambrose. Between the front and the back of the altar, the iconographic program forms parallels between the life of Christ, whose Passion and institution of the Eucharist form the central mystery of the Church, epitomized by the altar, and the life of St. Ambrose. Symbolically, Christ's Passion forms a rhetorical frame which locates the entombed saint within the circle of Christ and His Church, of inestimable value to the Milanese congregation as a powerful intercessor and protector. Additionally, the Ambrosian panels are highlighted with labels (tituli) which elaborate and explain the episode depicted on each panel.

\footnotetext{
${ }^{101}$ Cynthia Hahn, "Narrative on the Golden Altar of Sant'Ambrogio in Milan: Presentation and Reception," Dumbarton Oaks Papers, 53, 1999, 169.

102 The discussion of the Basilica Martyrum and the creation of the first Ambrosian altar are addressed in the chapter on the Ambrosian foundations below.

${ }^{103}$ It is often called a paliotto, but in fact, the altar is not an altar frontal, but is completely finished on all sides. The altar was commissioned by Bishop Angilbertus II (824-859) and created by the artist Wolvinus, one of the few early medieval works that is associated with a particular artist.
} 
St. Ambrose's panels are based on two sources: ten of the episodes are taken from Paulinus' Vita Ambrosii, the remaining two draw on Gregory of Tours' Libri de virtutibus sancti Martini episcopi, the vita of St. Martin of Tours. The selection of the scenes has very little to do with the Ambrosian theology or politics which caused the Church to name Ambrose among the gloriosi Doctors of the Church, ${ }^{104}$ but rather focuses on the hagiography of the saint. As such, the first panel shows the swarm of bees lighting on the baby Ambrose's mouth, depositing honey, which is linked as an attribute to his name.
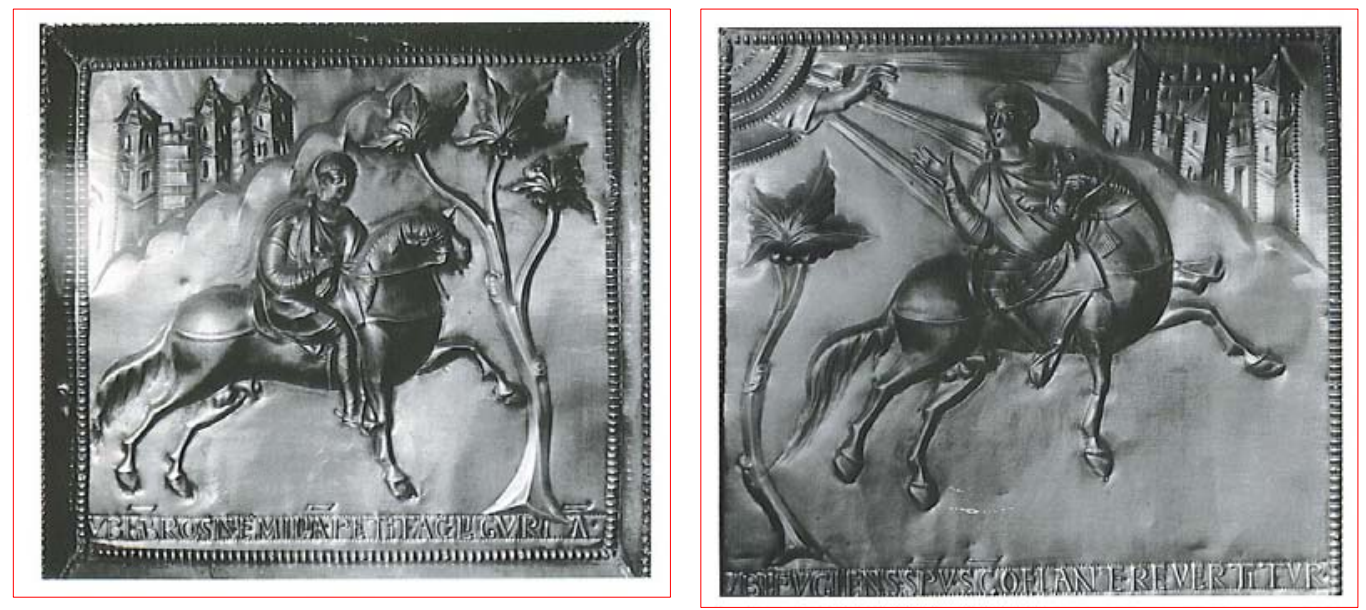

Figures 6 and 7: Milan: Sant'Ambrogio, Golden Altar ( $9^{\text {th }}$ c.), Ambrose leaves Rome as governor of Aemelia-Liguria and flees to escape the election of the people of Milan

The next two panels show Ambrose on horseback, one representing Ambrose leaving Rome to take up his duties as governor of Aemilia-Liguria, the other shows the famous night ride to escape the people of Milan. The panels form a pendant pair on either side of the central area. In both panels, Ambrose is shown as a noble (indicated by the fact that he is riding a stallion), an exemplar of pride, worldliness and power. But it is not the miraculous acclamation of the people that is shown. Instead, God himself reaches out to bring Ambrose to his senses. The titulus below the panel reads:

\footnotetext{
${ }^{104}$ With St. Jerome, St. Augustine of Hippo, and St. Athanasius. The total number of Doctors of the Church, which includes the complementary four hierarchs of the Eastern Church, is thirty-three.
} 
"In which, while fleeing, he is turned back by the breath of the Holy Spirit," which Hahn notes is a detail that Paulinus does not record. ${ }^{105}$ The comparison to St. Paul's conversion on the road to Damascus is inescapable: even the horse is jolted by the insistence of the Holy Spirit. Coincidentally, the tradition of the founding of the see by St. Barnabas first appears at the end of the eighth century ${ }^{106}$; the implication of an apostolic reference not only enhances Ambrose's potency as a saint, but elevates the see of Milan with which he is so intimately joined.

We are fortunate to have a portrait of the saint, which forms one of the mosaic panels within the Chapel of San Vittore in Ciel d'Oro (S. Sartiro), attached to Sant'Ambrogio, the chapel where Ambrose interred his brother. Ambrose is placed between the two saints who are interred with him, Gervasius and Protasius, while on the opposite wall are a matching complement of three panels of St. Nabor, Bishop St. Maternus, and St. Felix. As Beat Brenk notes, the mosaic program, which Brenk dates safely from the second half of the fifth century, ${ }^{107}$ is designed to show the four martyrs recommending the two bishops to Heaven. ${ }^{108}$ While it is generally difficult to make a case for the 'likeness' of late antique mosaic portraiture, Brenk believes that the mosaic represents a true likeness by virtue of its execution very shortly after the death of Ambrose in 397 (in which case, the mosaicist would very likely have been familiar with

\footnotetext{
${ }^{105}$ Hahn, "Narrative on the Golden Altar," 173.

${ }^{106}$ See below, Chapter III, "The Early History of the See of Milan."

${ }^{107}$ Beat Brenk, "Homo coelestis o dell'Anonimato Fisico dei Santi nella Tarda Antichità," Architettura e Immagini del Sacro nella Tarda Antichità (Spoleto: Fondazione Centro Italiano di Studi sull'Alto Medioevo), 2005, 273, "Nel caso in cui il mosaicista avesse conosciuto il metropolita di Milano, morto nel $397 \mathrm{~d}$ C., il mosaico non può essere stato realizzato molto dopo il $400 \mathrm{~d}$.C...Non è facile determinarne la cronologia: è forse più verosimil situarla nella seconda piuttosto che nella prima metà del V secola."("In the case of the mosaicist having known the metropolitan of Milan, who died in 397 A.D., the mosaic could not have been made much later than $400 \mathrm{~A}$. D [ But] it is not easy to determine the chronology: and it is probably more realistic to place it [the mosaic] in the second half of the fifth century rather than first half." Translated by the author.)

${ }^{108}$ Beat Brenk, "Homo coelestis," Architettura e Immagini, 272.
} 
the bishop's physiognomy). He also notes that the panels depicting the martyrs, who died in the third century, are generic portraits drawn from a stock vocabulary, while the artist appears to have made every attempt to individualize the portraits of the bishops. ${ }^{109}$

To buttress this argument, Brenk points to the portrait of Bishop Maximian in the Eucharist mosaics of Ravenna's San Vitale (dedicated 547 by Bishop Maximian).

Standing amongst the court officials with the Emperor Justinian, none of whom had ever been to Ravenna, the startlingly individualistic portrait of the bishop who commissioned the mosaics stares sternly at his congregation (Figure 11).

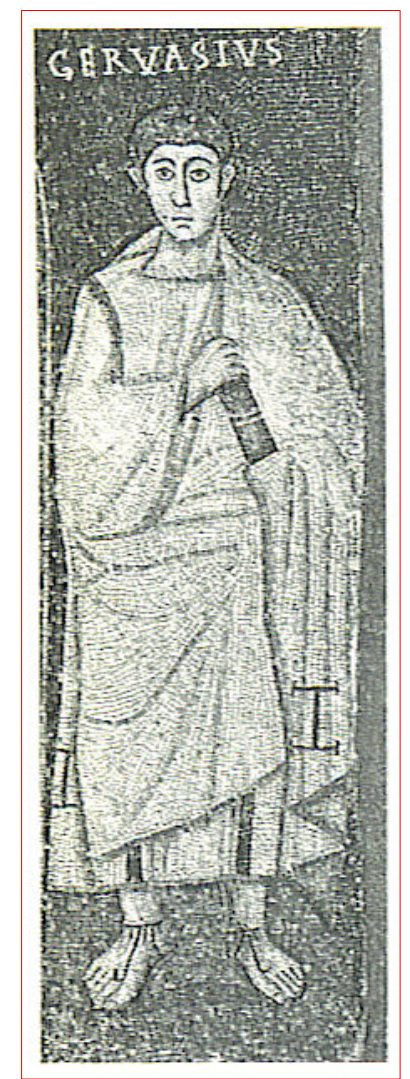

Figure 8: Milan: S.

Sartiro, Gervasius, $\left(5^{\text {th }} \mathrm{c}.\right)$

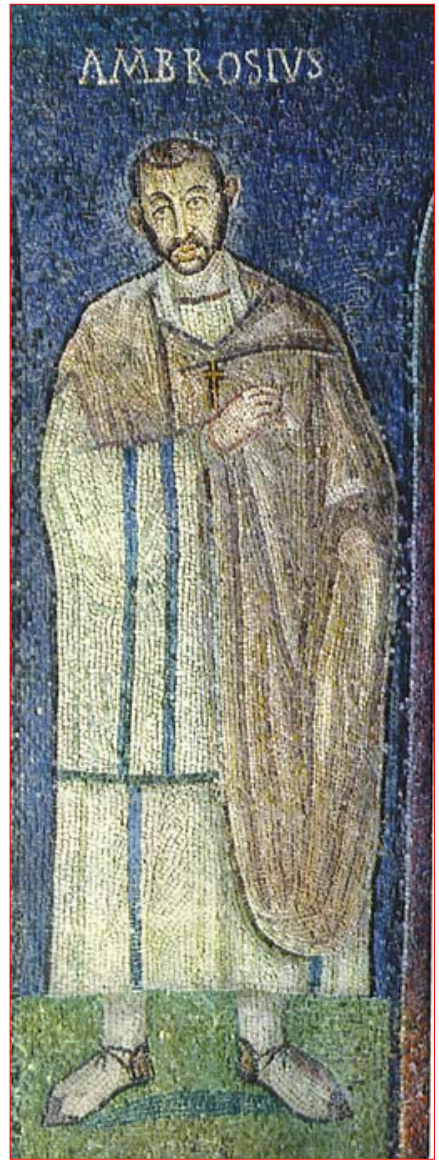

Figure 9: Milan: S. Sartiro, Ambrosius, $\left(5^{\text {th }} \mathrm{c}\right.$.)

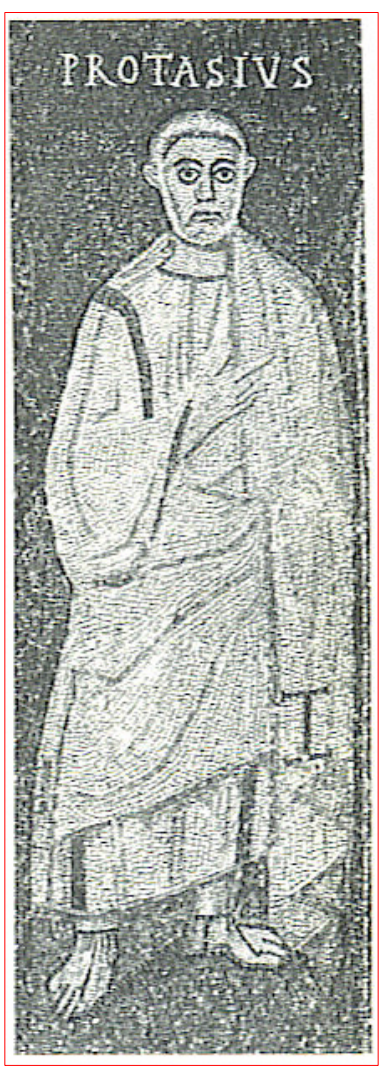

Figure 10: Milan: S. Sartiro, Protasius, $\left(5^{\text {th }} \mathrm{c}.\right)$

\footnotetext{
${ }^{109}$ Brenk, "Homo coelestis," Architettura e Immagini, 273.
} 


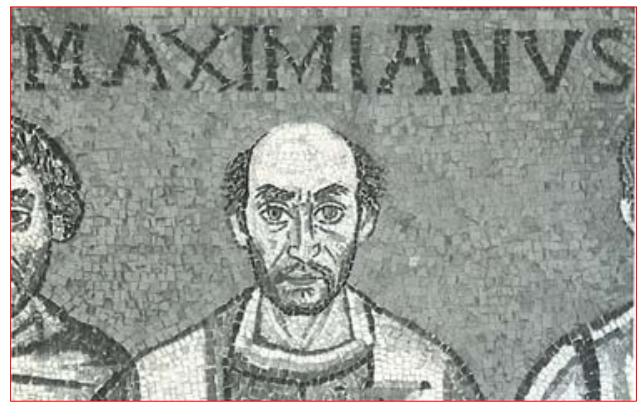

Figure 11: Ravenna: San Vitale, Bishop Maximian $\left(6^{\text {th }} \mathrm{c}.\right)$

Without epigraphical or

documentary evidence, the question of Ambrose's likeness will remain problematic, and the concept of the "true likeness" of a portrait is essentially anachronistic for the fifth century; for the most part individuals were portrayed symbolically and the question of likeness was irrelevant. However, there are several elements associated with Ambrose's portrait that warrant consideration. Ambrose is dressed very simply, in the standard tunic which includes the colored stripes of the magisterial class, ungirdled, over which a brown chlamys or paenula (which was probably of unbleached wool) is fastened with a simple brooch in the shape of a cross. He also wears sandals. In fact, he appears to be dressed as a Roman gentleman of the patrician class.

Although Constantine apparently donated a hieran stolēn (sacred robe) of gold tissue to his cathedral church in Jerusalem for the use of the bishop (330), ${ }^{110}$ Gregory Dix notes that the Western bishops drew on their Roman roots, in which priests performed their sacerdotal duties in ordinary dress, and that this practice largely prevailed over the graeco-oriental type of liturgical dress. ${ }^{111}$ Pope Celestine I, writing $c a .425$, went so far as to rebuke the bishops of southern Gaul for their tampering with the simplicity of their vestment (they had added the pallium and stole). He wrote:

\footnotetext{
${ }^{110}$ Gregory Dix, The Shape of the Liturgy (London: Dacre Press, A. and C. Black, Ltd.), 1945, 399.

${ }^{111}$ Dix, The Shape of the Liturgy, 399.
} 
It is small wonder that the church's custom should be violated by those who have not grown old in the church, but entering in by some other way have introduced into the church along with themselves things which they used to wear in another walk of life... ${ }^{112}$ Perhaps men who dwell in distant parts far from the rest of the world wear that dress from following local custom rather than reason. Whence came this custom in the churches of Gaul, so contrary to antiquity? We bishops must be distinguished from the people and others by our learning not by our dress, by our life not by our robes, by purity of heart not by elegance...

$$
(\text { Celestine I, Epistolae, iv) })^{113}
$$

Celestine further enjoins them to have done with such "worthless superstitions." adds that, during the fourth and fifth centuries, Celestine's injunctions were largely followed; priests and bishops ministered to their congregations in the garments of everyday life, ${ }^{115}$ although the pallium (a simple woolen scarf which was initially a badge of office worn by the emperor and consuls) and stoles (also badges of office) were inescapable. When, in the sixth and seventh century, lay fashion adopted the dress of the so-called 'barbarians,' ecclesiastical conservatism remained vested in the dress of the Church's beginnings; what was initially archaic became hieratic. ${ }^{116}$ The liturgical vestments of the medieval and the present-day Roman Church have continued to be based upon the simple design of male Roman clothing (though one may certainly argue that the spirit of Celestine's injunctions was not followed).

It is difficult to determine from the mosaic whether Ambrose is tonsured or wearing a very small skullcap. Ambrose has a very short, Roman haircut and is also bearded and mustached. Bishop Maximian, who is also bearded with a mustache, may be tonsured, but may also be showing the male pattern baldness that Roman tonsuring

\footnotetext{
${ }^{112}$ Dix, The Shape of the Liturgy, 401. By which he means the magistracy, from which, like Ambrose, many bishops were recruited.

${ }^{113}$ Dix, The Shape of the Liturgy, 401

${ }^{114}$ Dix, The Shape of the Liturgy, 401.

${ }^{115}$ Dix, The Shape of the Liturgy, 404.

${ }^{116}$ Dix, The Shape of the Liturgy, 404.
} 
mimics. ${ }^{117}$ In his commentary on Ezekiel which was designed for the diaconate, Jerome disapproved of the practice (Ezech, xliv) (414) ${ }^{118}$ and tonsuring by the secular clergy does not appear to have been in general practice prior to the fifth century. The Eastern Church incorporated the tonsure into the rite of the first stage of ordination (lector),

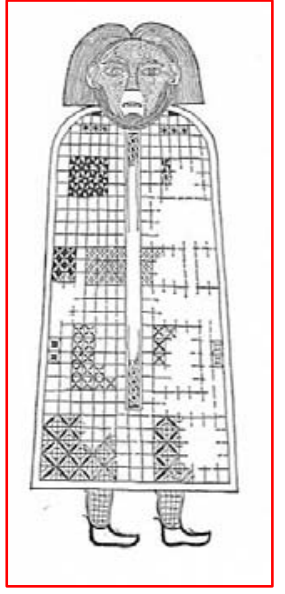
shaving the entire head. The clergy of the Celtic Church shaved the entire front of the head from ear to ear, leaving the back hair long. ${ }^{119}$ McLynn finds the personality of Ambrose, as revealed in his writings, elusive and curiously opaque. It is quite true that Ambrose's sacred writings do not invite the intimacy of inner life that we experience through the writings of Augustine or Jerome (whose

Figure 12: Evangelist sojourning in the different parts of the eastern and western empire the Book of Durrow $\left(7^{\text {th }} \mathrm{c}.\right)($ Celtic tonsure) and whose innate crankiness gave him all the attributes of a persistent gadfly). To a large extent, Ambrose concealed himself in demeanor; he was known for his absolutely impeccable manners. ${ }^{120}$ When Jerome turned on him after the Council of Aquileia, ${ }^{121}$ Ambrose did not deign to reply, showing a patrician disdain. ${ }^{122}$

\footnotetext{
${ }^{117}$ Tonsuring was a Roman practice that identified slaves and was adopted initially by eremitic monks. The Catholic Encyclopedia Online, s.v. "Tonsure," http://www.newadvent.org/cathen/14779a.htm (accessed February 27, 2008).

${ }^{118}$ The Complete Works of St. Jerome, http://www.fourthcentury.com/index.htm?http\&\&\&www.fourthcentury.com/jerome/jerome_worksnew.ht m (accessed March 17, 2008).

${ }^{119}$ The Catholic Encyclopedia Online, s.v. "Tonsure," http://www.newadvent.org/cathen/14779a.htm (accessed March 17, 2008).

${ }^{120}$ McLynn, Ambrose of Milan, xiv.

${ }^{121}$ McLynn, Ambrose of Milan, 289. Jerome never explained why he turned on Ambrose, whom he had initially praised lavishly as "noster Ambrosius (Jerome, Epistolae, xxii.22)," but writing from Bethlehem after he had left Rome in dudgeon, he refers to Ambrose as an "ugly crow, decked out in another's feathers," and several years later, in his translation of Origen's homilies on Luke, he again characterizes Ambrose as an "ugly, ill-omened crow, resplendent with bright hues stolen from other birds." McLynn suggests that the ever-sensitive Jerome could not forgive Ambrose for aligning himself with the "senate of Pharisees" that drove him from Rome, not because Ambrose participated in that action, but rather because he remained passive to Jerome's appeal for aid.

${ }^{122}$ McLynn, Ambrose of Milan, 289.
} 
His writing reflects the classical organization of the lawyer/rhetor and even his letters appear to have been organized for public consumption. ${ }^{123}$ The rather enigmatic picture that emerges is of a man whose romanitas both drives him and conceals him, urbane and sophisticated; if not entirely at ease with his mission, determined both to succeed and prevail. There is, perhaps, a free-floating uneasiness, difficult to define, that his personal agenda (perhaps the more worldly perquisites that accrue to men of ambition, fame, and power) was inextricably linked with the Church's agenda of orthodoxy in the north. Perhaps it is this that was revealed to Jerome's spiritual third eye, made keen, so to speak, by the scouring of the desert.

Nevertheless, a few things emerge from his writings and those of his contemporaries which, as the man himself said, clothe the soul. ${ }^{124}$ Augustine was drawn to his kindness ("Suscepit me paterne ille homo dei et peregrinationem meam satis episcopaliter dilexit. Et eum amare coepi primo quidem ...tamquam hominem benignum in me. (Augustine, Confessions, 5. xiii. 23),"125 and he was known to cry easily: for his brother, for penitents, for the fate of unknowns who were the victims of imperial tyranny, for the loss of his old friends. ${ }^{126}$ St. Augustine, who deferred his baptism until his mother, St. Monica, almost despaired, was so inspired by Ambrose's preaching that he asked for

\footnotetext{
${ }^{123}$ Testa, "Christianization and Conversion," The Origins of Christendom in the West, 80. The collection of ninety-two letters which we have are probably the ones that were collected by Ambrose for eventual publication, but it is accepted that they form a small part of an extensive correspondence that has been lost. ${ }^{124}$ Dudden, St. Ambrose, 461, "The flesh is the apparel of the soul, which is clothed with a body as with a garment" (Ambrose, Hexameron vi. 39).

${ }_{125}$ McLynn, Ambrose of Milan, xiv ("That man of God received me like a father, and looked with a benevolent and episcopal kindliness on my change of abode. And I began to love him.... as a man friendly to myself.").

${ }^{126}$ McLynn, Ambrose of Milan, 366. Paulinus (Vita Ambrosii, xl) notes that the "bitter tears" with which Ambrose greeted the death of Eventius of Pavia was the last in the list of old friends that he had mourned in the two years following Theodosius' death in 395; the effort to replace him precipitated his death on Easter Sunday, 397, a death that Paulinus said that Ambrose predicted (Paulinus, Vita Ambrosii, xl. 2).
} 
the sacrament at his hand. ${ }^{127}$ Ambrose apparently loved children. Three grandchildren of his friend Eusebius of Bologna lived with him while they were being educated, and, in a letter to the grandfather, he relates that he has administered some medicine for the child's cough (Ambrose, Epistolae, liii. 2). ${ }^{128}$ It is a touching picture of the bishop tending a small child. He was not without humor, and apparently could not resist the low art of punning. ${ }^{129}$ Dudden reproduces Ambrose's description of the preparations for a patrician's dinner party which could be used without change for a stand-up comedy routine. ${ }^{130}$ He appears to have been a man who was naturally ascetic ${ }^{131}$ with a tensile, nervous energy ${ }^{132}$ that propelled him with absolute fearlessness. McLynn notes that, unlike other bishops who railed as voices "crying in the wilderness" 133 at a safe distance, Ambrose faced and prevailed over three emperors; all three are reported to have died with his name on their lips. ${ }^{134}$ In his letters to his sister, he believed that these confrontations would ultimately crown him with martyrdom (and it is possible that he hoped for martyrdom), but that possibility did not intimidate him. Near the end of his life, he

\footnotetext{
${ }^{127}$ McLynn, Ambrose of Milan, 119. His preaching was apparently more dynamic than his writing, which was often derivative and culled from multiple sources. McLynn notes that De spiritu sancto, written for the edification of the Emperor Gratian, which was taken for the most part from Didymas, so outraged Jerome that he immediately penned a diatribe, accusing Ambrose of turning good Greek into bad Latin and a virile and compelling argument into something "feeble and soft, sleek and pretty, decorated with prose that reeks of delicate perfumes." (Jerome, Interpretatio libri Didymi de spirtu sancto, praef: 'totum flaccidum, molle, nitidum atque formosum, et exquisitis hic inde odoribus pigmentatum.')

${ }^{128}$ St. Ambrose, Letters, trans. Sister Mary Melcior Beyenka, O. P. (NY: Fathers of the Church, Inc.), 1954, 414.

${ }^{129}$ McLynn, Ambrose of Milan, 281. I don't hold this against him, being myself rather partial to the pun.

${ }^{130}$ Dudden, St. Ambrose, 464, De Elia, 24, 25. Ambrose's sermons are incidentally valuable for the very vivid view they provide of life in $4^{\text {th }}$ century Milan.

${ }^{131}$ Ramsey, Ambrose, 211, which is Paulinus (Vita ambrosii, 38): "The venerable bishop was a man of great abstinence and of many vigils and labors. Every day he would afflict his body with fasting." He admired and counseled personal asceticism with sermons on fasting, drunkenness, gluttony, gambling, debauchery, and the usages of the rich. The Christian population of Milan apparently gave him plenty of material.

${ }^{132}$ McLynn, Ambrose of Milan, 368. McLynn notes that Ambrose's health was as fragile as Augustine's.

${ }^{133}$ Mark 1:3.

${ }^{134}$ McLynn, Ambrose of Milan, xiii.
} 
refused to give communion to the Emperor Theodosius until Theodosius had made a

public penance for the massacre at Thessalonica (390). ${ }^{135}$

Paulinus records an eerie incident which he, and only he, witnessed. While taking dictation from the bishop, a small flame appeared over Ambrose's head and then entered

his mouth, "like a householder his home," and the bishop's face became "as white as

snow." Paulinus, who was so stunned that he lost his place in the dictation, was relieved

to discover that the bishop had been quoting scripture, which he was able to fill in

afterwards (Paulinus, Vita Ambrosii, xlii). ${ }^{136}$

Ambrose of Milan was a successful imperial governor, well-acquainted with the

political implications and entwining of imperial service. By force of will he re-invented

\footnotetext{
${ }^{135}$ McLynn, Ambrose of Milan, 315. In the summer of 390, Theodosius ordered his troops to punish the people of Thessalonica, apparently in a rage upon learning that the restive population had killed his general Butheric in a riot following an incident when a popular charioteer was imprisoned by Butheric, supposedly for making sexual advances to one of his attendants. For three hours, the army mowed down the population of the city, leaving thousands dead. Few were spared in the orgy of the carnage, the innocent suffering with the guilty rioters, the wealthy with the hoi polloi, the women and children with the men. The event is shrouded in mystery, both in the silence of the sources as to what exactly precipitated the problems in Thessalonica, and in the interpretation of the viciousness of Theodosius' response. Theodosius regretted his action almost immediately, but it was too late. To prevent the possibility of such a thing ever happening again, Theodosius issued a law in Verona in mid-August, which established a procedure for crimes to be investigated, and for a grace period of thirty days should the emperor decide that a severe punishment was in order (Codex Theodosiani, 9. xl. 13). Ambrose refused to greet the emperor upon his return to Milan, pleading sickness. He then wrote a personal letter to the emperor, begging him to make penance for the massacre, and informed him that he would be excommunicate until he had done so. After consideration (and much negotiation between the court and the bishop), Theodosius appeared before the people of Milan, tearfully admitting his responsibility for the murder of innocents, soliciting the prayers of the faithful. $\mathrm{He}$ performed public penance in front of the church, and accepted the responsibility of being a penitent, kneeling among the other members of the church who were penitents. In April of 391, the term of his penance ended, and Ambrose welcomed him back to the communion rail.

Although this incident has been seen as one of the earliest victories for the Church in its battle to have complete autonomy from the control of the civil authority, anticipating Canossa, a truer reading may be had in the consideration of the context of the time and the personalities of the principal players. While it is true that Ambrose's authority was enhanced by the emperor's capitulation, Ambrose did not address the issue as a confrontation between Church and State. Instead, he gave the emperor an opportunity to turn a public relations nightmare into a success. By characterizing the emperor's criminal temper as a momentary lapse into sin, and demonstrating the horrific effects that resulted from that sin, Theodosius recognized that he could be relieved of the responsibility of his failure to act as a temperate and just governor. Ambrose was willing to cooperate in supporting the stability of the government, and Theodosius was canny enough to see that public penance was a very small price to pay, and one that realigned him with the people of the Empire.

${ }^{136}$ McLynn, Ambrose of Milan, xvii.
} 
himself into the consummate churchman, drawing on the same qualities of determination, education and sophistication that had promoted his success as a civil servant. He brought to his duties a subtle and flexible legal mind with superior administrative experience, the confidence and courage of the Roman patrician, a seemingly inexhaustible supply of energy, and the fervent conviction that he was doing God's work in God's Church in God's corner of the world known as northern Italy. 


\section{CHAPTER III}

\section{THE EPISCOPACY OF AMBROSE}

\section{The Early History of the See of Milan}

The removal to Milan of the western imperial capital by Maximian at the end of the third century and Constantine's subsequent decision to leave Italy to build Constantinople (never returning to the Italian peninsula after 326), ${ }^{137}$ enhanced Milan's value as the second great city of Italy, ${ }^{138}$ politically superseding Rome as the seat of imperial government in the Latin West. ${ }^{139}$ Though the Senate in Rome continued to sit and to communicate to the Augusti, the city itself had become politically irrelevant. ${ }^{140}$

Ecclesiastically, in the fourth century, Italy had only two dioceses: the Urbicarian (Roman) diocese, which included that part of Italy south of Reggio and Florence, and the northern Italian diocese of Italie, ${ }^{141}$ administered by the only metropolitan in northern Italy, the bishop of Milan. ${ }^{142}$ As such, the jurisdiction of the see extended south and east to Ravenna ${ }^{143}$ and Aquileia (which would not be detached until the fifth century), ${ }^{144}$ west

\footnotetext{
${ }^{137}$ Krautheimer, Three Christian Capitals, 39.

${ }^{138}$ Krautheimer, Three Christian Capitals, 70-71, citing Ausonius who ranked it seventh among the cities of the Empire in his Ordo urbium nobilium (c. 385).

${ }^{139}$ Krautheimer, Three Christian Capitals, 71. "The nearly unbroken presence of the emperors from Constans and Constantius II to Theodosius I, ever returning there from campaigns and administrative forays, made the city between 340 and 402 the principal seat of imperial power in the western half of the orbis Romanus."

${ }^{140}$ Humphries, Communities of the Blessed, 42. "The Eternal City and peninsular Italy were effectively political backwaters, and it was thanks only to a certain cultural nostalgia that they were at all important." ${ }^{141}$ King, Liturgies of the Primatial Sees, 289.

${ }^{142}$ King, Liturgies of the Primatial Sees, 289.

${ }^{143}$ King, Liturgies of the Primatial Sees, 289, 292. The removal of the imperial capital to Ravenna by the emperor Honorius in 402/3 presaged the decline of Milan politically. As a metropolitan see in the fifth
} 
and south to Nice and Genoa. ${ }^{145}$ Additionally, the transalpine area of Rhaetia Prima was included in its jurisdiction, which encompassed Augsburg and Ratisbon; ${ }^{146}$ these and the upper Danubian provinces were divided between Milan and Aquileia in the fifth and sixth centuries. ${ }^{147}$ Edwards (Lewis) includes the diocese of West Illyria, which then was included in the Praefecture of Italy as was Africa, ${ }^{148}$ but it appears that the bishops of

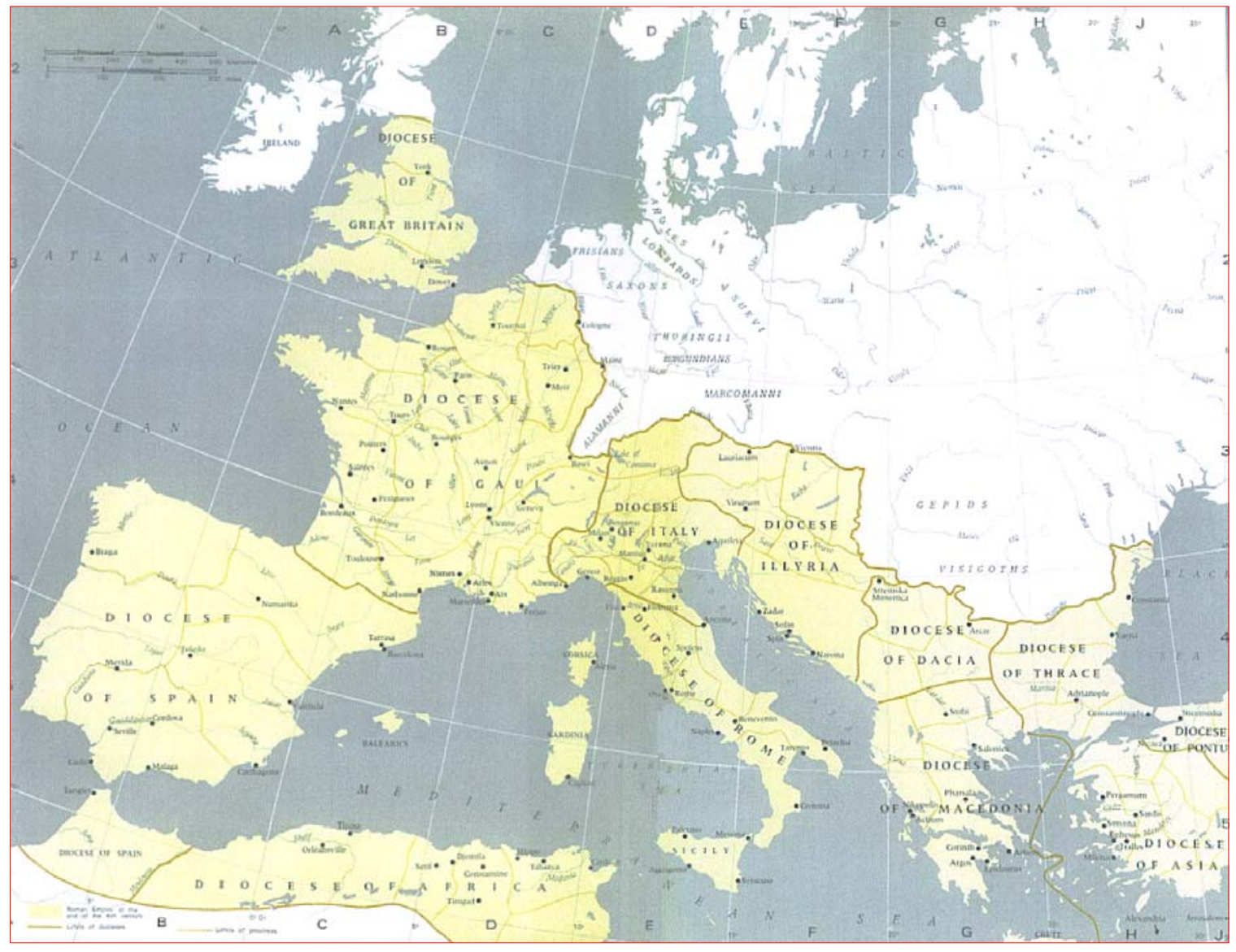

Figure 13: The Christian Dioceses of the fifth century

century, the bishop of Ravenna became a suffragan of Rome, receiving some of the bishoprics of Aemilia that were detached from Milan at that time.

${ }^{144}$ Dudden, St. Ambrose, 64. and King, Liturgy of the Primatial Sees, p. 289.

${ }^{145}$ King, Liturgies of the Primatial Sees, 289, 292.

${ }^{146}$ King, Liturgies of the Primatial Sees, 289.

${ }^{147}$ King, Liturgies of the Primatial Sees, 289.

${ }^{148}$ Edwards (Lewis), "Two Critical Aspects of Fourth-Century Architecture at Milan," 61. 
Illyricum enjoyed a stronger tie with Aquileia. ${ }^{149}$

Unlike the sees of Rome and the eastern Empire, the see of Milan was not an apostolic see. The earliest historical evidence occurs at the beginning of the fourth century, although Archdale A. King suggests that it had been in existence for at least a century prior to that. ${ }^{150}$ The episcopal Catalogus records that the first bishop of Milan was St. Anatolius; beyond the fact that he was the bishop for thirteen years, nothing more is known of him, other than the fact that since he has a Greek name, he was probably Greek. $^{151}$ Edwards (Lewis) and Testa suggest that the see could have been established at approximately the same time as Aquileia, whose founding bishop was also Greek. ${ }^{152}$ If that is so, then the see was founded between 193 and 243, between the reign of Septimius Severus and the death of Gordian III. Eusebius (Historia ecclesiae, v. 1) reports that missionaries from Ephesus were sent to Gaul during the second century, which would suggest that the earlier date for could represent the founding of the see. ${ }^{153}$

The tradition of the see also claims the martyrs St. Calimerus (286) and St. Monas (300) as early bishops, ${ }^{154}$ but the first historical bishop for which there is literary evidence is St. Myrocles (304-315), who appears as the representative of Milan in the conciliar lists of the Council of Rome administered by Pope St. Miltiades in 313, and again at the Council of Arles in the following year. ${ }^{155}$ Ambrose, writing to the younger Valentinian in February 386, refers to him as one of his most worthy predecessors as he

\footnotetext{
${ }^{149}$ Humphries, Communities of the Blessed, 32.

${ }^{150}$ King, Liturgies of the Primatial Sees, 289.

${ }^{151}$ Edwards (Lewis), "Two Critical Aspects of Fourth-Century Architecture at Milan," 60.

${ }^{152}$ Edwards (Lewis), "Two Critical Aspects of Fourth-Century Architecture at Milan,” 60, and Testa, "Christianization and Conversion," The Origins of Christendom in the West, 52.

${ }^{153}$ Edwards (Lewis), “Two Critical Aspects of Fourth-Century Architecture at Milan,” 60.

${ }^{154}$ King, Liturgies of the Primatial Sees, 288, citing Achille Ratti, La Chiesa Ambrosiana, Conferenze di Storia Milanese (Milan, 1897) p. 157.

${ }^{155}$ Dudden, St. Ambrose, 63.
} 
traces the lineage of his episcopacy, ${ }^{156}$ and again in his Sermo contra Auxentium de basilicis tradendis (February or March, 386): "Sed et hoc addidi: 'Absit ut tradam hereditatem est [sic] Dionysii qui in exilio in causa fidei defunctus est, hereditatem Eustorgii confessoris, hereditatem Mirocletis atque omnium retro fidelium episcoporum." 157 Bishop Myrocles was succeeded by Bishop Maternus (who is depicted in the mosaics of S. Sartiro along with Ambrose), who was succeeded by Bishop Protasius ( irca 342/343); his presence in Milan was noted by Athanasius, along with the bishops of Aquileia, Verona, and Capua. ${ }^{158}$ Protasius' successor was Bishop Eustorgius I (also mentioned by Athanasius), ${ }^{159}$ who was succeeded by Bishop St. Dionysius (exiled by Constantius II), and Auxentius of Cappadocia (struck from the lists by his sainted successor). Ambrose was, therefore, the tenth (or eleventh, if Auxentius' nineteen year tenure is included) incumbent of the altar of Milan.

The tradition that the see was an apostolic foundation established by St. Barnabas is a late addition to the history of the see for which there is little contemporary

\footnotetext{
${ }^{156}$ Humphries, Communities of the Blessed, 57.

${ }^{157}$ Humphries, Communities of the Blessed, 57: "And I added further: God forbid that I shall give up the inheritance of my fathers, that is, the inheritance of Dionysius, who died in exile in the cause of the faith; the inheritance of the Confessor Eustorgius, the inheritance of Myrocles and of all the faithful bishops of bygone days." His immediate predecessor, Auxentius, is neither included nor recognized because of his anti-Nicene (Arian) beliefs. However, the Auxentius against whom this sermon was preached, shortly after Ambrose's occupation of the Portiana, was not the former bishop of Milan, but the bishop of Durostorum, a disciple of Ulfila (the Arian Bishop of the Goths), who moved to Milan upon the accession of Theodosius, seeking the protection and support of the dowager empress, Giustina. Ambrose accused Auxentius of being the eminence grise of a law issued in Milan by the teen-aged Valentinian II in January 386 which affirmed the freedom of assembly of those who followed the faith established at Constantius' councils of Rimini and Constantinople (the anti-Nicene position), making any 'turbulent' opposition a capital offense. Ambrose (very rightly) believed that this law was directed at himself in his continuing battle with the empress for control of all the churches of Milan. See McLynn, Ambrose of Milan, 181.

${ }^{158}$ Edwards (Lewis), "Two Critical Aspects of Fourth-Century Architecture at Milan," 61.

${ }^{159}$ Edwards (Lewis), "Two Critical Aspects of Fourth-Century Architecture at Milan," 61.
} 
evidence; ${ }^{160}$ it was not mentioned by Ambrose in his sermon, though he invokes an apostolic tradition of martyrdom. ${ }^{161}$

Ambrose brought the same dedication to his duties as the spiritual mentor of the Christians of Milan that had characterized and promoted his career as a civil servant. $\mathrm{He}$ initially relied on his old teacher and mentor, Simplicianus, to instruct him, devoted himself to the study of scripture and doctrine, and sought guidance from those bishops and priests whom he believed had experience and understanding by virtue of their long commitment to the Church. ${ }^{162}$ Only a bishop could interpret scripture, ${ }^{163}$ and Ambrose routinely preached to his congregation; he appears to have felt more secure exegetically with the Old Testament texts, and his Holy Week sermons developed a pattern of readings that distinguished them from the Roman canon. ${ }^{164}$ He believed that the instruction and baptism of catechumens were pivotal to the integrity of the body of the Church, and he took extraordinary pains to ensure that catechumens were properly prepared. Paulinus notes that Ambrose took more interest and was more diligent in this matter than the five bishops who succeeded him (Paulinus, Vita Ambrosii, xxxviii) ${ }^{165}$, and

\footnotetext{
${ }^{160}$ King, Liturgies of the Primatial Sees, 287. By Alciatus, copying an epigraphical text found during the restoration of the tomb of St. Calimerus by Bishop Thomas (755-784): Divo Calimer Mediol. Lyguriaq(ue) summon sacerdoti qui successit Castriciano qui Caio [sic] qui Anateloni qui Barnabae apostolo. The legend of St. Barnabas' founding of the see became enshrined in the history of the see through the centuries; Achille Ratti, a preceptor of the Ambrosian Library (later Archbishop of Milan and Pope Pius $\mathrm{XI})$ believed the legend to have been firmly established by the eleventh century during the episcopacy of Aribert da Entimiano, when its political value lent cachet to the see.

${ }^{161}$ King, Liturgies of the Primatial Sees, 287. Ambrose believed that Bishop Dionysius was a martyr to Constantius II, and that he himself would suffer martyrdom as a result of Valentinian's law. In his sermon, Ambrose invokes (from the apochryphal) Acts of Peter the Apostle Peter (Sermo contra Auxentius de basilicis tradendis, 12-13.) as his example. Once spared martyrdom when he was led out of prison by an angel, Peter could have again evaded the authorities had he not met Christ as he left Rome. Peter asked him, "Lord, where are you going?" To which Christ responded, "I am going to be crucified again." By this answer, Peter knew that he needed to return to Rome and face his own martyrdom.

${ }^{162}$ Testa, "Christianization and Conversion," The Origins of Christendom in the West, 79.

${ }^{163}$ Testa, "Christianization and Conversion," The Origins of Christendom in the West, 84.

${ }^{164}$ King, Liturgies of the Primatial Sees, 298.

${ }^{165}$ Boniface Ramsey, Ambrose (London and New York: Routledge, 1997), 211.
} 
since he would not allow himself to be absent from Milan during Lent, ${ }^{166}$ we can infer that it was his concern for his catechumens (who would be baptized during the Easter vigil) that kept him there.

In addition to his weekly preaching, Mass was said daily in Milan, and at least four offices of psalmody were sung daily. Augustine, commenting on devotion, relates that his mother St. Monica attended Mass daily in Milan and additionally went in the morning and in the evening, "not for vain gossip and old wives' fables, but that she might hear Thy words and Thou mightest hear her prayers (Augustine, Confessions, v. 9)."167 The last service, the vigil, might be a simple office, or it might be all night, depending on the need. The shorter vigil was left-over from Ambrose's occupation of the Portiana during his confrontation with Valentinian II and the Dowager Empress Giustina. ${ }^{168}$ On the evening before the feast day of a martyr, or in the dedication of a church, the vigil would be all night. ${ }^{169}$ Ambrose had little use for sleeping the night away:

The day is not enough for prayer; you must rise also in the night and at midnight. The Lord Himself passed the night in prayer, that He might invite you to pray by His own example...The Lord Jesus will arouse you; He will admonish you to rise and arm yourself with prayer at the time when the tempter is accustomed to make his attack... The Spouse is wont to come at midnight; beware lest He find you sleeping, beware lest through drowsiness you be not able to light your lamp.

... and do you think that the whole night is to be assigned to sleep? Then is the Lord to be the more entreated by you, this protection to be more sought and guilt to be more guarded against, when there appears to be secrecy; then above all, when darkness is round about me and walls shut me in, must I reflect that the Lord beholds all hidden things.

We are to blame if we spend the whole long night in idleness, without rendering any devotion or offering the spiritual sacrifice. Do you not know, O man, that you owe the first-fruits of your heart and voice daily to the Lord?...Anticipate this

\footnotetext{
${ }^{166}$ Dudden, St. Ambrose, 115.

${ }^{167}$ Dudden, St. Ambrose, 442.

${ }^{168}$ See below.

${ }^{169}$ Dudden, St. Ambrose, 446.
} 
sun which you see. If you anticipate this sun before it rises, you shall see Christ radiating light. When you say, With my soul have I desired thee in the night, He Himself will make the morning light to shine for you in the night hours.

$$
\text { (Ambrose, Expositio psalmi cxviii) }^{170}
$$

In addition to his pastoral duties, Ambrose continued to function as a magistrate in civil cases that had been referred to the ecclesiastical courts from the secular courts. ${ }^{171}$ Bishops increasingly were burdened with civil cases; Augustine's biographer Possidius says that the bishop of Hippo routinely spent the whole morning, and frequently the whole day, hearing cases (Possidius, Vita Augustini, 19). ${ }^{172}$ The bishop often took up the cause of the oppressed, defending those, such as widows and orphans, who had little protection from the State. ${ }^{173}$ Ambrose also superintended the charities of the Church which included the relief of the poor and dowries for young women who had nothing to offer prospective husbands, care of the sick and convicts, hospitality to the homeless, the maintenance and education of orphans, and the burial of the pauper dead. Drawing on the realities of his secular experience, Ambrose cautioned his deacons not to be tricked by professional beggars:

Nowhere is the greed of the beggars greater than it is here. They come, though they are strong and healthy; they come for no reason but that they are on the tramp. Not content with a little, they ask for more. They parade their rags, that they may entice you to comply with their demands. They try to persuade you to increase your alms by telling you lies about their noble birth. Many pretend they have debts. They protest with tears that they have been stripped of everything by robbers. Do not believe it unless the misfortune be proved or the sufferer be personally known to you.

(Ambrose, De officiis, ii. 77) ${ }^{174}$

\footnotetext{
${ }^{170}$ Dudden, St. Ambrose, 445-446.

${ }^{171}$ Dudden, St. Ambrose, 121.

${ }^{172}$ Dudden, St. Ambrose, 121.

${ }^{173}$ Dudden, St. Ambrose, 119.

${ }^{174}$ Dudden, St. Ambrose, 117.
} 
We hear less the voice of the saint in this passage than that of the magistrate.

Of all of the opportunities for almsgiving that were possible, Ambrose believed that the ransom of captives warranted the most generous liberality. Following the defeat of Valens' army at Hadrianople in 378, thousands of people were taken prisoner when the Goths invaded Illyricum. Ambrose sold Church gold and plate to contribute to the ransoms to free the prisoners, an action that was strongly criticized by the anti-Nicenes, who hoped to discredit the bishop. ${ }^{175}$ The bishop was undeterred by claims of sacrilege:

It is far better to preserve souls for the Lord than to preserve gold. For He who sent forth the apostles without gold, also gathered together the churches without gold. The Church has gold - not, however, that she may store it up, but that she may spend it in helping those who are in necessity. If we were to save up our gold and silver, surely the Lord would be likely to say, "Why have so many captives been offered for sale in the market? Why have so many, who were not redeemed, been slain? It would have been better to preserve living vessels than metal ones." And what reply could we make to Him? Should we plead that we feared that God's temple would be left without adornment? He would answer, "The sacraments need not gold. They are not bought with gold, and therefore gold is not required to beautify them. The adornment of the sacraments is the redemption of captives."...It is right that the gold of the Redeemer should contribute to the work of delivering those in peril.

$$
\text { (Ambrose, De officiis, i. 158) })^{176}
$$

Ambrose developed his pastoral style through determination and study, but his natural talent, which had been trained and honed as an advocate, was in organization, and Ambrose might quite rightly be called the first bishop of the Western Church whose episcopacy was characterized by the administration of Church business that ultimately became the burden of all bishops. He gathered around him an absolutely devoted presbyterate, many of whom were not Milanese; those that did not live up to his standards,

\footnotetext{
${ }^{175}$ In 378, Ambrose's episcopacy was only four years old, and the routing of the anti-Nicenes at the Councils of Constantinople and Aquilea was yet three years away (381).

${ }^{176}$ Dudden, St. Ambrose, 118.
} 
he encouraged to move on. ${ }^{177}$ Those who stayed with him, he groomed for episcopacy, and during the period of his incumbency, he created many new bishoprics; northern Italy was still in the process of conversion, and dominated by large sees. Ambrose, in adding bishoprics staffed by men whom he had brought up, ${ }^{178}$ created a northern Italian hierarchy that was far more closely linked to its metropolitan than it would ever be to the bishop of Rome. Ambrose maintained those linkages through an expansive correspondence that began with his accession; he exhorted, he instructed, he harangued, and if he thought it was necessary, he traveled. ${ }^{179}$ Almost all of his efforts were directed in one direction: the triumph of orthodoxy in northern Italy. ${ }^{180}$

Under Ambrose's episcopacy, the luster of the see continued to be burnished, a fact that is underscored by a remarkable statement by Msgr. Duchesne: "For a short but important period it would thus appear that the Western episcopate recognized a twofold hegemony - that of the Pope and that of the bishop of Milan." ${ }^{181}$ It was Ambrose who presided over the Council of Aquileia (even though it was under the nominal presidency

\footnotetext{
${ }^{177}$ McLynn, Ambrose of Milan, 253. He so disliked the slovenly gait of one cleric that he refused to allow him ever to walk in front of him. Palladius, in his bitterness after the Council of Aquileia, complained of rough treatment from Ambrose's juniors, 'men trained by you after your own character,' (Palladius, Apol. 116).

${ }^{178}$ Felix of Como, Gaudentius of Brescia, Vigilius of Trent, Bassianus of Lodi, Constantius of Claterna, Sabinus of Piacenza, Honoratus of Vercelli, to name a few. Several of the Ambrosian elite became bishops in cities that were outside the jurisdiction of Milan, e. g., Theodulus of Modena and Felix of Bologna. Chromatius of Aquileia (who succeeded Valerian) was consecrated by Ambrose.

${ }^{179}$ His bishops were not always happy to see him. His intervention in a case in Verona placed the bishop in the equivocal position of having his authority undermined when Ambrose reversed the man's ruling.

${ }^{180}$ Testa, "Christianization and Conversion," The Origins of Christendom in the West, 80.

${ }^{181}$ Louis Duchesne, Christian Worship: Its Origin and Evolution, trans. by M. L. McClure (London: Society for Promoting Christian Knowledge, 1904), 32. It should be noted that the Pope, bishop of Rome, though revered as St. Peter's spiritual descendant, was not yet regarded as the Vicar of Christ, primus inter pares, but rather as the patriarch of the West vying with the ancient patriarchs of the eastern empire and Africa. The ascendancy of Milan's influence might be said to have coalesced the papal defense for primacy. Certainly, the creation of the Ravenna metropolitan (as a suffragan of Rome) with the Aemilian sees of Milan was one of several strategies that the popes employed to promote their claim to primacy in the West.
} 
of its saintly and ascetic bishop, Valerian) ${ }^{182}$ which was convened in 381 to root out the traces of Arianism in the lower Danubian provinces. ${ }^{183}$ Both Gaul ${ }^{184}$ and Spain appear to have recognized the ecclesiastical authority of Milan as an equal if not superior tribunal: Spain appealed to Bishop Ambrose in the Priscillian problem ${ }^{185}$ and the Council of Toledo in 400 appealed to both Pope St. Anastasius and Bishop St. Simplicianus (Ambrose's successor). ${ }^{186}$ Even the Church in Africa, convening councils in 393, 397, and 401 in an effort to resolve the continuing problem of the repercussions of the

\footnotetext{
${ }^{182}$ Humphries, Communities of the Blessed, 120. This council was convened by the Emperor Gratian on Ambrose's suggestion to deal with the Christological Debate in Italy, as Theodosius I had dealt with it at the Council of Constantinople in May 381. The council was to probe the orthodoxy of two Illyrian bishops, Palladius of Ratiaria and Secundianus of Singidunum. Ambrose succeeded in having both bishops removed from their sees, which was probably not Gratian's intention, but the emperor's youth was against him and he was willing to be guided by his bishop. Palladius' bitterness was circulated in letters throughout the Eastern and Western Church. It was after the Council of Aquileia that Jerome turned the full force of his criticism on Ambrose. Though wholly pro-Nicene, Jerome was always sensitive about the time that he spent in Aquileia as a member of the community of ascetics that gathered around the saintly Fortunatianus (Valerian's predecessor) and he recognized that Ambrose had dominated the council to achieve his own purposes.

${ }^{183}$ Humphries, Communities of the Blessed, 120.

${ }^{184}$ Duchesne, Christian Worship, 34: "Before the bishop of Milan, the most important bishops of Gaul felt themselves in the presence of a superior authority, and believed themselves bound to accept his decisions." The bishops of Gaul had submitted several questions of ecclesiastical law to the council of Turin, convened by Milan in 400 under Bishop St. Simplicianus. Its decrees were subsequently incorporated into the canonical collections of Gaul.

${ }^{185}$ King, Liturgies of the Primatial Sees, 291. The Priscillian heresy originated in Spain in the fourth century. It was derived from the Gnostic-Manichean Dualist beliefs (as promoted by an Egyptian from Memphis named Marcus) which emphasized extreme asceticism. It was adopted by four Spanish bishops, of whom one, Priscillian of Avila, was pre-eminent. Condemned by the council of Sargossa in 380, the bishops continued to defy the synod's decrees, which appealed to the Emperor Gratian for enforcement of their sanctions. The emperor deprived the condemned bishops of their churches and ordered them into exile. Journeying to Rome, the bishops were denied audience by Pope Damasus, who refused to hear their appeal. Ambrose of Milan also denied them hearing when they reached Milan. The Emperor Gratian having been murdered in Paris, the usurper emperor Maximus called for a council in Bordeaux (384) to consider the evidence. The Spanish Church's conciliar enforcer Itacius was so vehement in his denunciation of the Priscillianists that St. Martin of Tours, who was in Trier with the emperor, begged for, and received, a promise from the emperor that no blood would be shed. When St. Martin left to return to his see in Tours, however, Maximus, with the vision of a healthy replenishment of his treasury from confiscations before his eyes, accused Priscillian of magic and had him executed. The other bishops were sent into exile. This action by the emperor was roundly denounced by the Pope, Ambrose, St. Martin, and most of the Gallican bishops, who deplored the Spanish Church's resort to the civil authorities to punish heretics. The martyrdom of Priscillian re-inspired his followers and like many heresies of the patristic period, Priscillianism proved difficult to eradicate. As late as 563 we find the council of Braga legislating against Priscillianists. (The Catholic Encyclopedia Online, s. v. "Priscillianism," http://www.newadvent.org/cathen/12429b.htm, (accessed February 7, 2008)).

${ }^{186}$ Duchesne, Christian Worship, 33.
} 
Donatist heresy, sought guidance from the various incumbents of the sees of Rome and Milan. ${ }^{187}$ That this competition for authority of the Western Church continued to be an issue of concern to the popes is made clear by a letter from Pope Innocent writing to his own suffragan, the bishop of Eugubium, in the district of Umbria (which belonged to the metropolitan diocese of the Pope) of whom he asks querulously if they have read anywhere that the Churches of Italy, Gaul, Spain, Africa and the island of Sicily owe their foundation to others than to St. Peter and his successors. ${ }^{188}$ Though the political importance of Milan declined with the removal of the imperial court to Ravenna by Honorius in 402, the metropolitan of Milan continued to be a force to be reckoned with in northern Italy. Milan did not defer to the Urbicarian diocese until the latter years of the eleventh century and continued to appoint its bishops through the process of diocesan election with investment by the Emperor. ${ }^{189}$

${ }^{187}$ Duchesne, Christian Worship, 35. Guidance was sought from Ambrose, Pope St. Siricius and Bishop St. Simplicianus, Pope St. Anastasius and Bishop St. Venerius.

${ }^{188}$ Duchesne, Christian Worship, 87. “...Praesertim cum sit manifestum in omnem Italiam, Galliam, Hispanias, Africam, atque Siciliam insulasque interjacentes nullum instituisse ecclesias, nisi eos quos venerabilis apostolus Petrus aut ejus successors constituenrunt sacerdotes? Aut legant si in his provinciis alius apostolorum invenitru aut legitur docuisse (Innocent, Epistolae)."

${ }^{189}$ Charles I. Hemans, A History of Ancient Christianity and Sacred Art in Italy (London: Williams and Norgate), 1866, 556. Milan's archbishops have been translated to the Chair of St. Peter on at least three occasions. In addition to Pope Pius XI, Pope Urban III (1185-87) and Pope Alexander V (1409-10) were Milanese. Of the many bishop saints, the most illustrious (after Ambrose) is St. Charles Borromeo, the great Counter-Reformation archbishop. Interestingly enough, St. Charles Borromeo was not ordained until three years after his consecration as bishop. See King, Liturgy of the Primatial Sees, 295. 


\section{The Churches of Milan at the Time of Ambrose's Accession}

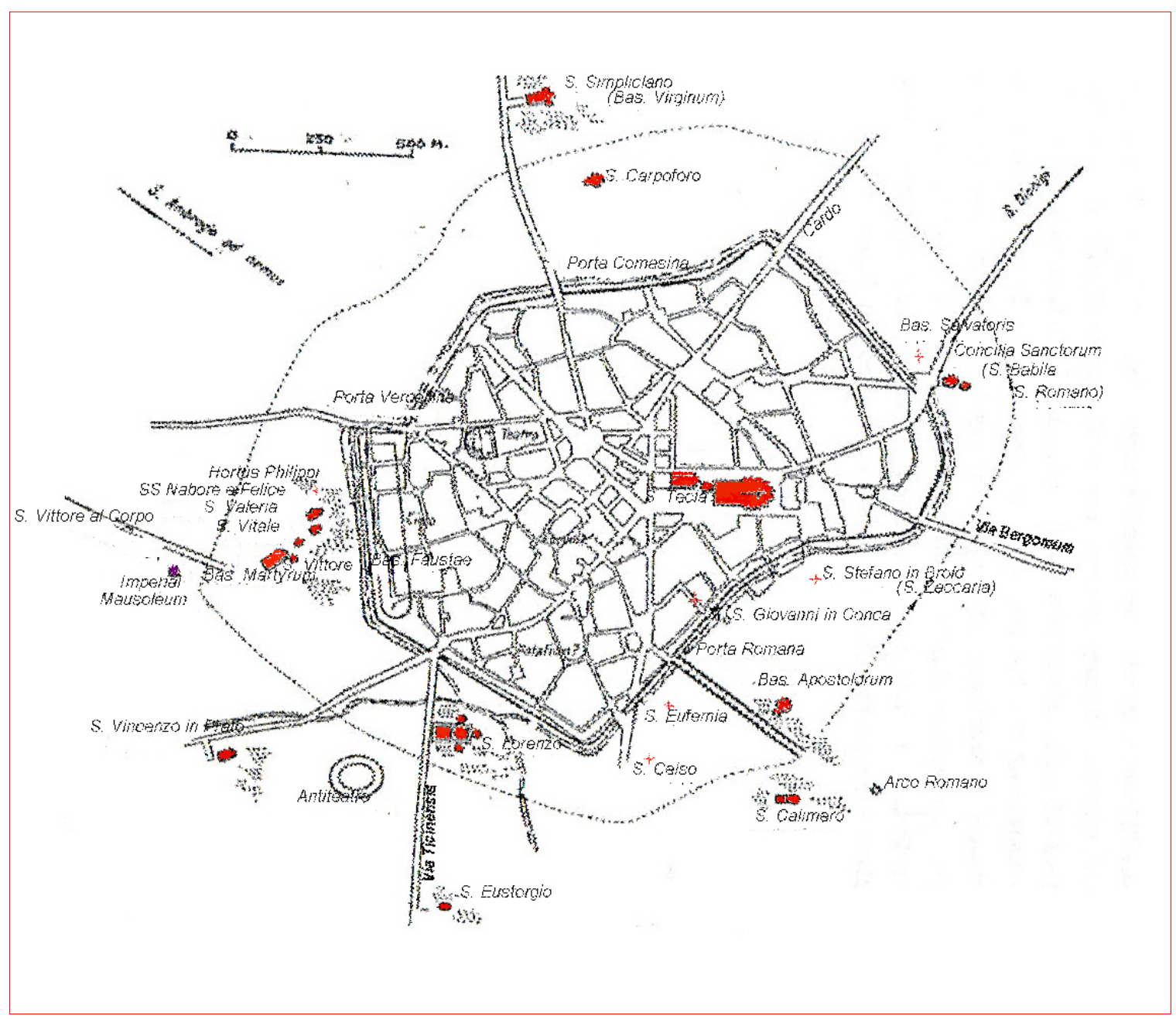

Figure 14: Late Roman and Early Christian Milan, c. 400

Milan had benefited from the presence of the imperial court and the stability of Bishop Auxentius' nineteen-year tenure (notwithstanding his confirmed Arianism). Unlike Rome, where Constantine had established his first Christian foundations as cemetery churches on private imperial property outside the walls of the city, ${ }^{190}$ Ambrose found himself in possession of an episcopal complex built squarely in the heart of the

\footnotetext{
${ }^{190}$ Krautheimer, Three Christian Capitals, 28. Krautheimer posits that Constantine sited the first Christian churches on private imperial property outside the walls so as not to offend the pagan sensibilities of the politically powerful senatorial class during the period when he was consolidating his power.
} 
city, for which public land had been dedicated. ${ }^{191}$ Although there is some confusion over which churches are identifiable as the churches to which Ambrose alludes, the plan in Figure 15 shows the episcopal complex relative to the present Gothic cathedral of Milan. Ambrose refers to a least two cathedrals, identified only as the Basilica vetera, the original cathedral, and Basilica nova, the new cathedral which was constructed sometime in the

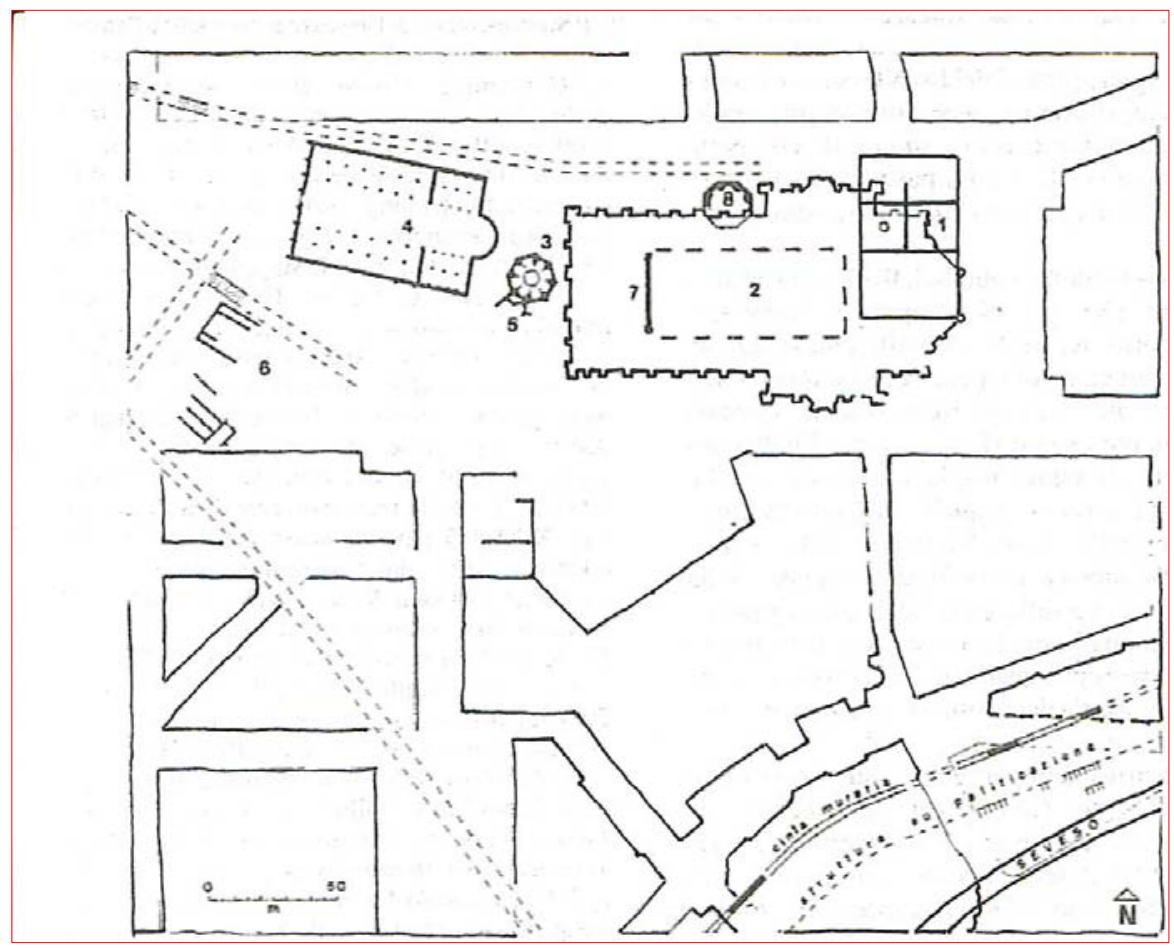

Figure 15: Piva's plan of the episcopal complex of Milan at the time of Ambrose's accession, showing: 0-1) the hypothetical double cathedral (basilica maior (south) and basilica minor (north), 2) footprint of S. Maria Maggiore beneath the Duomo (basilica nova) with its 7) extant Roman foundation, 3) the baptistery built by Ambrose, S. Giovanni alle Fonti, 4) Santa Tecla, 5) the remains of a small, apsed annex to the baptistery, 6) late antique residence and 8) the Romanesque campanile of S. Maria Maggiore

\footnotetext{
${ }^{191}$ Krautheimer, Three Christian Capitals, 76. The cathedral dedicated to St. Tecla forms yet another facet of the honeycomb nexus of Milan's alignment with the Eastern Church. Tecla's cult, the epicenter of which was Seleucia, was entirely based upon the apocryphal Acta Pauli et Theclae, which appeared c. 180 and enjoyed wide distribution in the East. In the Acta, Tecla is a disciple of Paul who dedicated herself to perpetual virginity and traveled with him, also preaching. She escaped martyrdom at least twice, finally achieving it in Seleucia. In the Eastern Church she is reverenced as a "Protomartyr among women and equal to the Apostles." See Stephen J. Davis, The Cult of Saint Thecla: A Tradition of Women's Piety in Late Antiquity (Oxford: Oxford University Press, 2001).
} 
middle of the fourth century. Paolo Piva, based upon the work done by Silvia Lusuardi Siena, has hypothesized that the Basilica vetus was, in fact, a double cathedral (shown on the plan as structure number 1) constructed in a manner similar to the ancient ${ }^{192}$ double cathedral of Aquileia. ${ }^{193}$ Piva suggests that this very old cathedral was built immediately following the Edict of Milan (313) under Bishop Myrocles' aegis. The cathedral incorporated the Basilica maior in its south hall, and the Basilica minor in its northern nave, as well as an interior baptistery, as shown in the illustration of Aquileia's double cathedral (Figures 16 and 17). Piva identifies the area shown as structure number 2 on the plan as the Basilica nova, which subsequently became the

Church of S. Maria Maggiore, and was

demolished in the construction of the

Duomo. Ambrose refers to both of these structures in his letter to his sister

Marcellina of April 386:

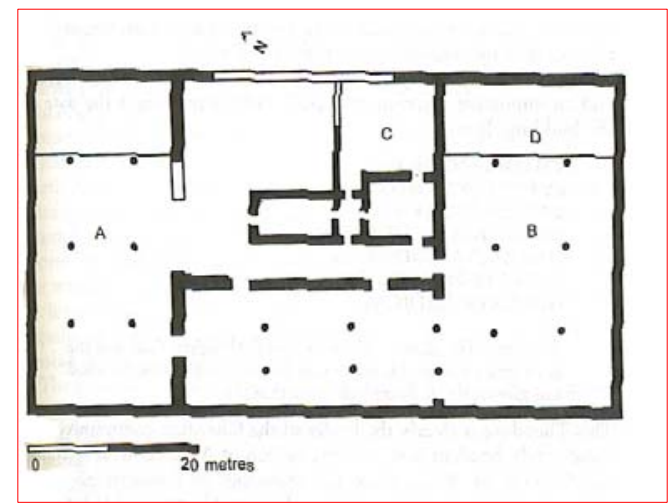

Figure 16: Double Cathedral of Aquileia (early $\left.4^{\text {th }} \mathrm{c}\right)$, A) northern hall,

B) southern hall (?catechumens),

C) baptistery, D) transennae

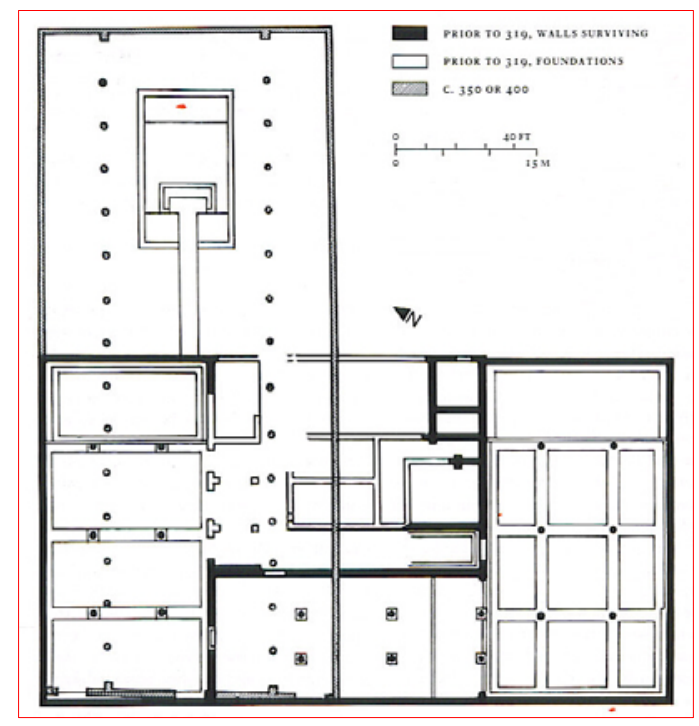

Figure 17: Double Cathedral of Aquileia, stages of $c$. 313-319 and c. 350 or 400

\footnotetext{
${ }^{192}$ The double cathedral of Aquileia was constructed on the foundation of a domus ecclesiae, early fourth century. See Richard Krautheimer, Early Christian and Byzantine Architecture (New Haven and London: Yale University Press), 1986, 43.

${ }^{193}$ Paolo Piva, "L'Ipotetica Basilica Doppia di Milano e la Liturgia Ambrosiana," Antiquite Tardive. (IV), 1996, 130.
} 
In most of your letters you make anxious inquiry about the church. Hear, then, what is going on: The day after I received your letter, in which you remarked that your dreams were troubling you, a great wave of serious disturbances began overwhelming us. This time it was not the Portian Basilica, that is, the one outside the walls, but the new basilica, that is, the one inside walls, the larger one.

\section{(Ambrose, Epistolae, xx. 10) ${ }^{194}$}

In the same letter he later states that he "spent the entire day in the old basilica." (Ambrose, Epistolae, xx. 10) ${ }^{195}$ Piva's concern lies in the fact that at his accession Ambrose found in place the baptistery dedicated to S. Stefano (shown as structure 3 in Figure 18 - this is the baptistery where Augustine was baptized), ${ }^{196}$ placed north and east of the basilica that he (Piva) identifies as S. Maria Maggiore. However, Ambrose subsequently built the baptistery that was attached to S. Tecla, dedicated to the Saints John (both the Baptist and the Evangelist). ${ }^{197}$ Given Ambrose's commitment and care to the liturgical aspects of baptism, Piva suggests that $\mathrm{S}$. Tecla was as yet not fully

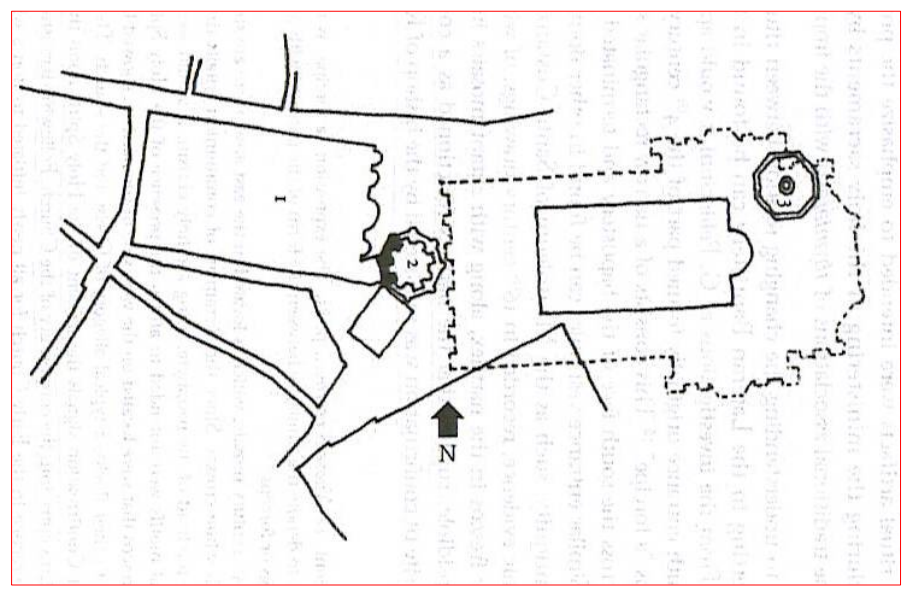

functional, since it did not have a baptistery (the Ambrosian baptistery is shown as structure 2 in Figure 18). ${ }^{198}$

Figure 18: Milan: The Baptisteries of the Episcopal Complex,

1) S. Tecla, 2) S. Giovanni alle Fonti (Ambrosian),

3) S. Stefano (the old baptistery)

${ }^{194}$ My emphasis.

${ }^{195}$ My emphasis.

${ }^{196}$ Dudden, St. Ambrose, 63.

${ }^{197}$ Piva, "L'Ipotetica Basilica Doppia di Milano e la Liturgia Ambrosiana," 130.

${ }^{198}$ Piva, "L’Ipotetica Basilica Doppia di Milano e la Liturgia Ambrosiana," 130. 
There are some problems with this, beyond the fact that my research has not found any references by Ambrose to three churches in the cathedral complex. Part of the problem lies in the fact that Ambrose uses both the terms Basilica vetus/Basilica nova and Basilica maior/Basilica minor; the terms may not necessarily reference the same structures, or maior/minor might indeed have been the Basilica vetus as a double cathedral, though not as Piva sites it. ${ }^{199}$

Krautheimer has given some thought to the conundrum of S. Tecla. ${ }^{200}$ The church was extraordinarily large. Measuring 82 by 45 meters, it rivaled Rome's Lateran cathedral in size, able to accommodate approximately three thousand people. ${ }^{201}$ Though he notes that the plan is irregular (all angles deviating from ninety degrees), Krautheimer suggests that this may have been conditioned by the site, within the heart of the city. ${ }^{202}$
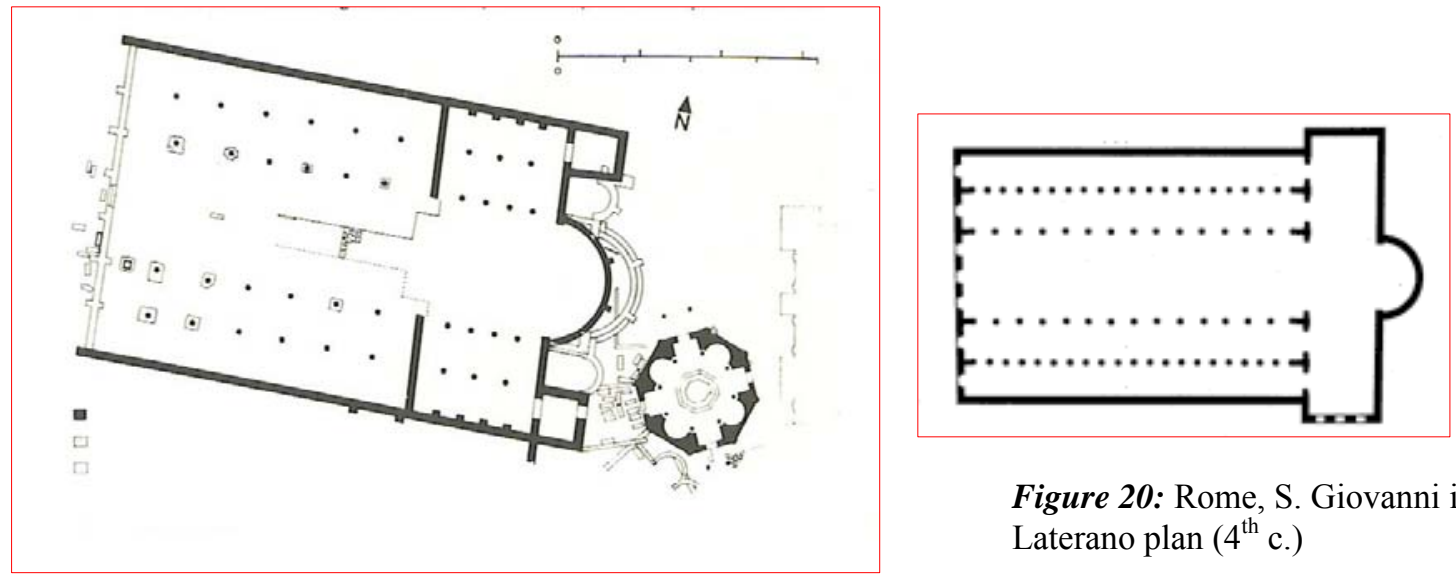

Figure 20: Rome, S. Giovanni in Laterano plan $\left(4^{\text {th }} \mathrm{c}\right.$. $)$

Figure 19: Milan: S. Tecla and the Ambrosian baptistery of S. Giovanni alle Fonti $\left(4^{\text {th }}\right.$ c. $)$

199 The double (twin) cathedrals were frequently the result of an addition to an existing structure (as at Aquileia), but were just as frequently so designed (as at Trier). The resulting pair of naves were designated as maior/minor and were sometimes used in different seasons. With the orientation of churches to the east, the north nave was frequently designated as the summer church, and the southern nave as the winter church. The twin cathedral had the additional value in providing for the liturgical purpose of the segregation of catechumens during the Mass of the Faithful. See Richard Krautheimer, Early Christian and Byzantine Architecture (New Haven and London: Yale University Press, 1986), 458, note 17 for examples of the popularity of the twin cathedral in northern Italy and the Adriatic provinces.

${ }^{200}$ Dudden, St. Ambrose, 63. As an example of the confusion attached to this church, Dudden refers to S. Tecla as the Basilica vetus, demolished to expand the Piazza of the Duomo. He places the Basilica novus beneath the Duomo.

${ }^{201}$ Krautheimer, Three Christian Capitals, 76.

${ }^{202}$ Krautheimer, Three Christian Capitals, 77. 
In spite of these deviations from the square, the church was well constructed with deep foundations of coursed and orderly riverbed pebbles and fine, regular brickwork with low beds of white mortar, indicating that the funds committed to the project had been sufficient to provide for superior work, which suggests imperial backing. ${ }^{203}$ Though there is no documentary evidence for the date of its construction, Krautheimer speculates that it was constructed during the period of the Emperor Constans' residence in Milan, perhaps between 345 and 350, and finished quickly in order to accommodate the Council of Milan of $355^{204}$ (the anti-Nicene council which witnessed the exile of Dionysius of Milan, Eusebius of Vercelli and Lucifer of Cagliari), noting that its size would have been required to accommodate the some three hundred bishop-delegates, as well as the imperial court and associated retinues. ${ }^{205}$ Edwards (Lewis) notes that the excavation ${ }^{206}$ revealed no traces of previous structures in the lowest strata; the church was therefore the first construction project on the site. ${ }^{207}$

The church encompassed several features that demonstrate that church architecture continued to be experimental. Like the Lateran, the nave was flanked by a pair of aisles on either side with widely spaced inner and outer colonnades, which were probably arcades. The axis of the nave continued into the chancel area to end in the central apse. The chancel itself had triple arcades on either side, supported by colonnades in which there was a lack of correspondence among the columns. This is also the case for the column supports of the nave. A slightly raised solea extended the full length of the nave leading to the chancel barrier, also slightly raised, which was placed at the entrance

\footnotetext{
${ }^{203}$ Krautheimer, Three Christian Capitals, 77.

${ }^{204}$ Following the accession of the anti-Nicene Constantius as emperor.

${ }^{205}$ Krautheimer, Three Christian Capitals, 77.

${ }^{206}$ Begun in 1943 by Capitani dArzago.

${ }^{207}$ Edwards (Lewis), “Two Critical Aspects of Fourth-Century Architecture at Milan,” 104.
} 
to the chancel area. In 400, the church was remodeled and the apse was made shallower. $^{208}$

The unusual tripartite transept arrangement attached to a five-aisled nave that distinguished S. Tecla occurred very rarely in northern Italy, although the Greek Church adopted the plan readily in the fifth century. ${ }^{209}$ The excavation of the Lateran's original transept element showed two small side rooms which projected from the side aisles, forming dwarf additions to the width of the transept. Krautheimer suggests that the function of the chancel wings served to accommodate the liturgy during the offertory; ${ }^{210}$ though the cathedral at Milan may have drawn on the Roman prototype, it was more likely an independent solution to a liturgical accommodation of the Milanese offertory. Different from the Lateran is the presence of the chancel barrier, a feature already present

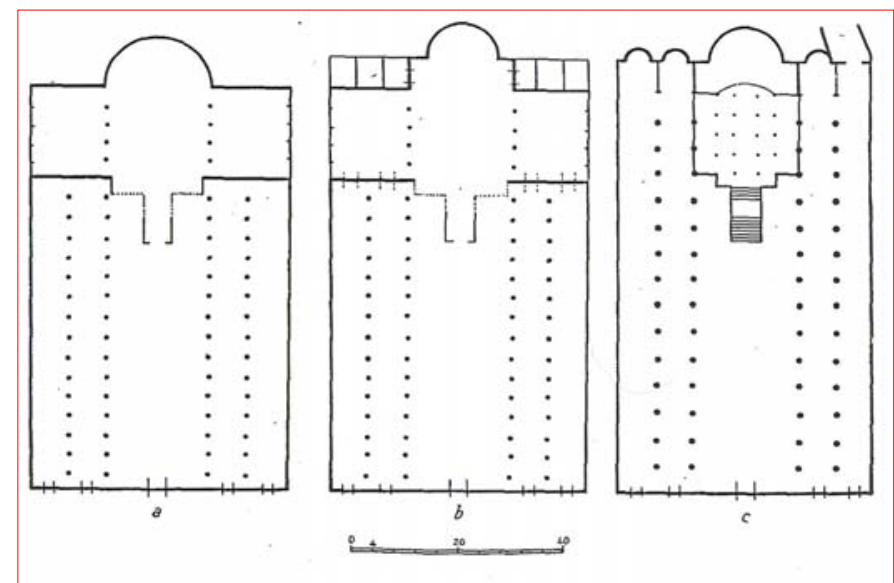

Figure 21: Milan: Three phases of reconstruction of S. Tecla, a) $4^{\text {th }}$ c. foundation b) $5^{\text {th }}$ c. renovation c) $11^{\text {th }}$ c. reconstruction (note the removal of the chancel barrier in the last phase) in Constantinople which continued to be a feature of Byzantine architecture, but which was to disappear in Rome by the sixth century. ${ }^{211}$

Beyond the episcopal complex, our knowledge of the Milanese churches and their

location at the time of Ambrose's accession is very slight. The Basilica Portiana, which figures so prominently in Ambrose's historic duel with the Empress Dowager Giustina,

\footnotetext{
${ }^{208}$ Richard Krautheimer, Early Christian and Byzantine Architecture, 84.

${ }^{209}$ Edwards (Lewis), "Two Critical Aspects of Fourth-Century Architecture at Milan," 107.

${ }^{210}$ Krautheimer, Early Christian and Byzantine Architecture, 84.

${ }^{211}$ Krautheimer, Early Christian and Byzantine Architecture, 84.
} 
was probably a palatine church, the present day S. Lorenzo Maggiore. ${ }^{212}$ Its magnificence ${ }^{213}$ deserves special treatment. A massive structure ${ }^{214}$ located on the Via

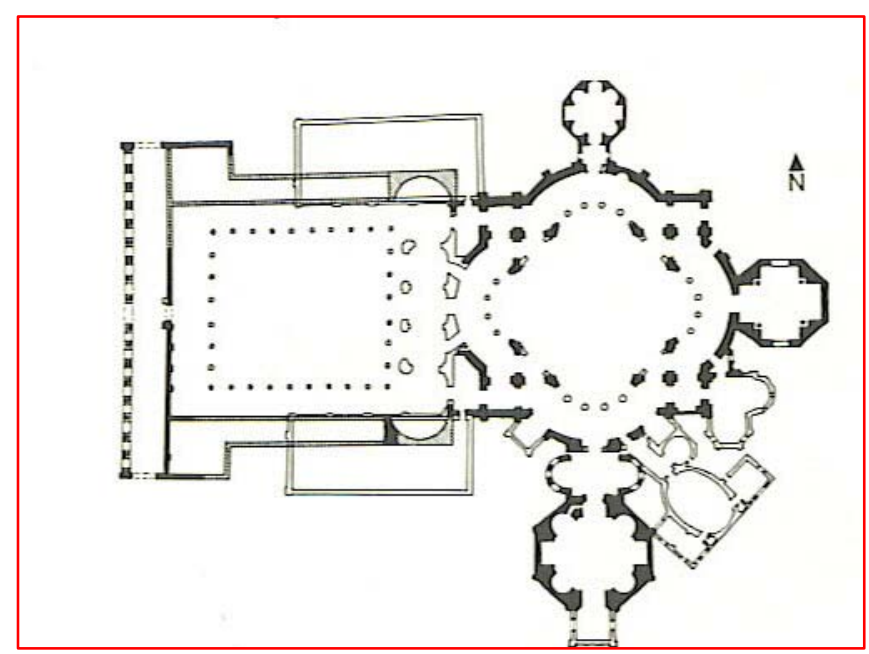

Figure 22: Milan, S. Lorenzo, plan (before 378)

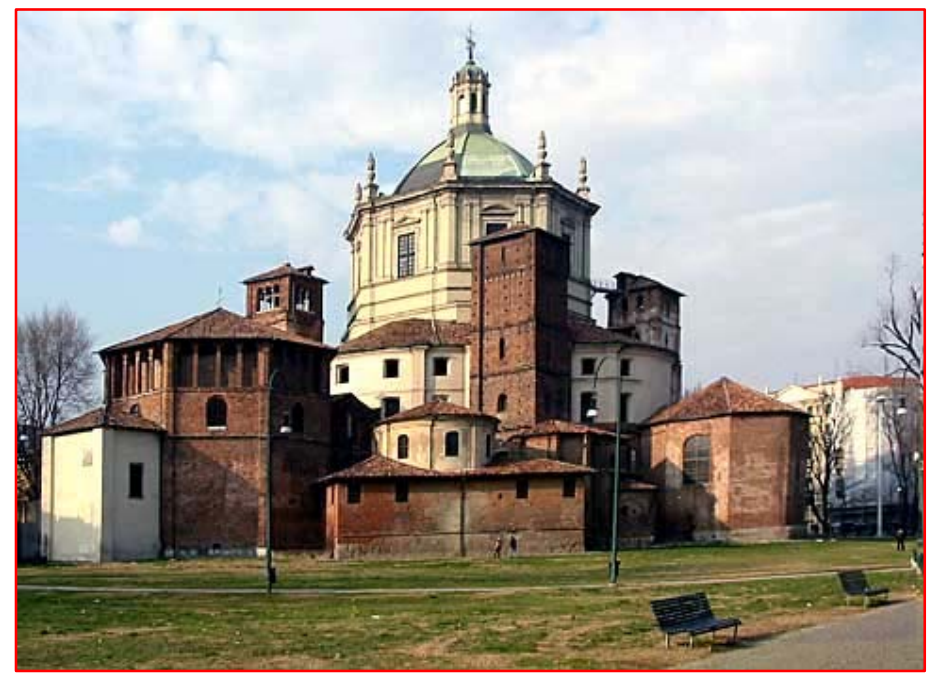

Figure 23: Milan, S. Lorenzo complex, southeast elevation
Ticinensis south of the imperial complex, the church is a doubleshell quatrefoil, comprised of a large central space (which forms a huge baldacchino) surrounded by galleries and ambulatories which are constructed in the outer shell. Adjoining the church on the south side is a niched, octagonal chapel, S. Aquilino, which was probably an imperial mausoleum. ${ }^{215}$ Tangent to the eastern hemicycle, a second chapel, S. Ippolito, forms another octagon with an inscribed Greek cross floor

plan. A third chapel, S. Sisto, tangent to the north hemicycle, is exactly half the size of S. Aquilino, and duplicates its plan. All of the Early Christian foundations and fabric

\footnotetext{
${ }^{212}$ Krautheimer, Three Christian Capitals, 86 and 88, noting that Dale Kinney identifies S. Lorenzo with the Portiana as well.

${ }^{213}$ Krautheimer, Three Christian Capitals, 81: "To me the church is still the most beautiful in Milan and among the most beautiful in the Western world."

${ }^{214}$ Edwards (Lewis), "Two Critical Aspects of Fourth-Century Architecture at Milan," 252: the vaulting would have covered a space $24 \mathrm{~m}$. square.

${ }^{215}$ Krautheimer, Early Christian and Byzantine Architecture, 81.
} 
of the walls are the same as those of the central quatrefoil, indicating that they were constructed at the same time as the main church. The entrance to the church, on the west side, which may have been introduced by a large narthex, was preceded by a magnificent

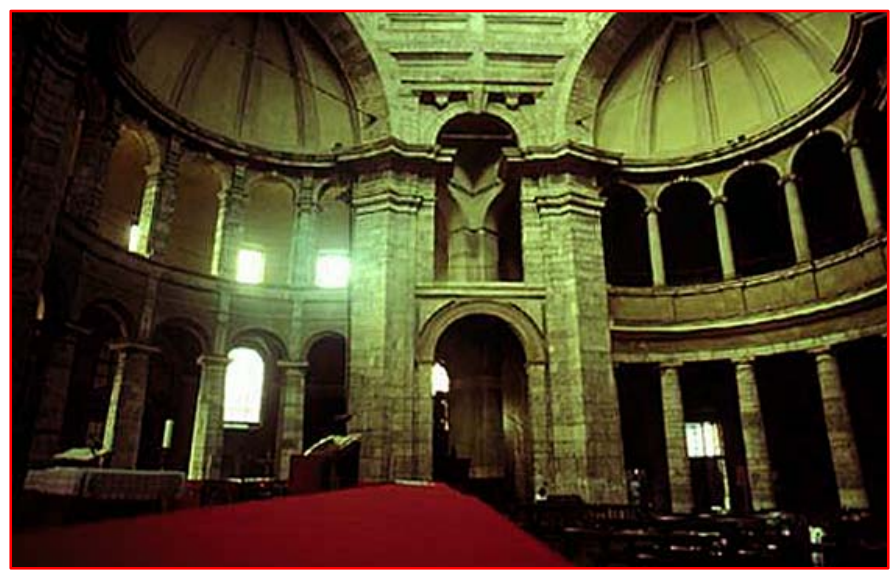

Figure 24: Milan, S. Lorenzo, interior (before 378) quadriporticus atrium.

The stark exterior of the church $^{216}$ belied its splendidly rich interior decoration. The walls were reveted with marble, and stucco friezes defined the walls and vaults. The windows, which were

wide, were arrayed in rows in the outer shell, lighting the galleries as well as the central space, and were also decorated with stucco tendrils. Krautheimer particularly notes the beautiful interplay of light and shadow which the windows produced. ${ }^{217}$ The central vault was carpeted with gold mosaic.

Historically, the chronology of the construction of S. Lorenzo, as well as the genealogy of its plan, has been problematic, creating a spectacularly magnificent Milanese enigma. Although the scholarship agrees that the church was a palatine complex, there is less agreement as to which member of the imperial family was responsible for its construction. Edwards (Lewis) has placed its construction in the period of Theodosius' first residence in Milan (388), ${ }^{218}$ but Krautheimer considers the period shortly before 378 (during Emperor Gratian's residence in Milan) to be more

\footnotetext{
${ }^{216}$ Krautheimer, Early Christian and Byzantine Architecture, 81: The present drum of the central space is $16^{\text {th }}$ century.

${ }^{217}$ Krautheimer, Early Christian and Byzantine Architecture, 81.

${ }^{218}$ Edwards (Lewis), "Two Critical Aspects of Fourth-Century Architecture at Milan,” 280.
} 
appropriate. ${ }^{219}$ He suggests that both the choice of a distinctly Eastern plan, unique in the West at this time, and the method of construction support the choice of the earlier date. Ambrose mentions two other churches: the Basilica Faustae ${ }^{220}$ (which Edwards (Lewis) believes was Sta. Valeria); ${ }^{221}$ and the church dedicated to the early Milanese martyrs Saints Felix and Nabor, the Naboriana ${ }^{222}$ (superseded by the Church of S.

Francesco in 1256). ${ }^{223}$ The research of Achille Ratti suggests that the most ancient church in Milan was dedicated to St. Babila, but Ambrose does not mention this church. ${ }^{224}$ However, Edwards (Lewis) suggests that S. Babila, once part of a basilical complex known as the Basilica ad Concilia Sanctorum which included the church of S. Romano, may have been either rebuilt (or more likely founded) by Bishop Laurentius (489-511). It was reconstructed in the eleventh century and again in the nineteenth century and has not been excavated. ${ }^{225}$

Edwards (Lewis) has been able to reconstruct several additional Christian loci; she admits their dating and siting are conjectural. Almost all of these structures were cemeterial, built, as most Christian structures were throughout the first three centuries of Christianity's tentative expansion, outside the walls of the city. However, Milan, unlike Rome, did not have a system of underground catacombs; all of the Christian burials in Milan were sub divo. ${ }^{226}$ In the southwestern quarter a privately owned property, the hortus Philippi, was donated for use as a Christian cemetery. A house church (domus

\footnotetext{
${ }^{219}$ Krautheimer, Early Christian and Byzantine Architecture, 81.

${ }^{220}$ Dudden, St. Ambrose, 62, citing Ambrose, Epistolae, xx. 2, the letter in which he recounts the finding of Sts. Gervasius and Protasius.

${ }^{221}$ Dudden, St. Ambrose, 63, and Edwards (Lewis), "Two Critical Aspects of Fourth-Century Architecture at Milan," 123 , note 69.

${ }^{222}$ Ambrose, Epistolae, xx. 2.

${ }^{223}$ King, Liturgies of the Primatial Sees, 287.

${ }^{224}$ King, Liturgies of the Primatial Sees, 287.

${ }^{225}$ Edwards (Lewis), "Two Critical Aspects of Fourth-Century Architecture at Milan," 101.

${ }^{226}$ Edwards (Lewis), "Two Critical Aspects of Fourth-Century Architecture at Milan," 78.
} 
ecclesia), the domus Philippi, established by Bishop Castricianus in the third century, may have been associated with this property which was donated during the tenure of Bishop Caius, Castricianus' predecessor. ${ }^{227}$ Edwards (Lewis), relying on the evidence of the Acts of St. Victor (fifth century), suggests that this structure may have been on the site of the present day S. Vittore al Corpo and would have been the earliest Christian structure in Milan. ${ }^{228}$ Since this cemetery became the Coemeterium ad Martyres where Ambrose located his own basilica, the Basilica Martyrum (also called the Ambrosiana and today known as Sant'Ambrogio), Edwards (Lewis) posits that a number of cellae memoriae were located here. The small martyrial churches of Santi Nabore e Felice, Sta. Valeria, and San Vitale grew out of these memorial structures, and it was here that Ambrose discovered the forgotten graves of Protasius and Gervasius, whose relics were translated to the Ambrosiana. ${ }^{229}$ These churches were very likely only small oratories; SS. Nabore e Felice was probably constructed in the third century when the bodies of the martyrs were brought to Milan from Lodi following the persecution of Diocletian. The church was rebuilt in the fifth century as a basilica church. ${ }^{230}$

Ambrose buried his brother in the chapel of San Vittore in Ciel D'Oro (S. Satiro), the excavation of which ${ }^{231}$ seems to indicate that the little chapel was like the other structures in the cemetery, a simple wooden-roofed, apsed, sepulchral cella dedicated to St. Victor that was trapezoidal in plan. Its later renovation, which consisted of significant

${ }^{227}$ Edwards (Lewis), "Two Critical Aspects of Fourth-Century Architecture at Milan," 80.

${ }^{228}$ Edwards (Lewis), "Two Critical Aspects of Fourth-Century Architecture at Milan," 80.

${ }^{229}$ Edwards (Lewis), "Two Critical Aspects of Fourth-Century Architecture at Milan," 81.

${ }^{230}$ Edwards (Lewis), "Two Critical Aspects of Fourth-Century Architecture at Milan," 81.

${ }^{231}$ By Reggiori in the 1950s. 
embellishments and modifications of the windows, vaulting and mosaic decoration are all datable from the middle of the fifth century to the beginning of the sixth century. The chapel, as excavated and restored by Reggiori is now a structural component of Sant'Ambrogio, accessible through a fore-chapel dedicated to St. Satyrus. Reggiori's reconstruction suggests that the chapel was open in the front and very small: the non-

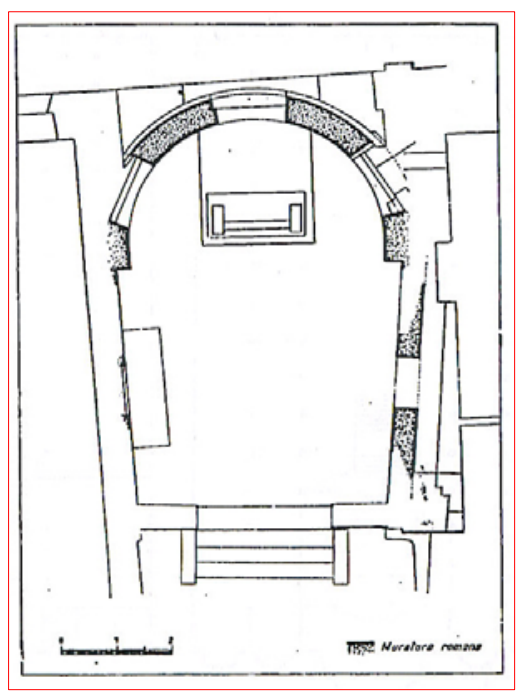

Figure 25: Milan: Reggiori's reconstruction of S. Vittore in Ciel d'Oro $\left(4^{\text {th }} \mathrm{c}\right.$. $)$ parallel walls measure $4.40 \mathrm{~m}$., the front wall is $4.5 \mathrm{~m}$.

wide, and the width of the apse is $4.60 \mathrm{~m}$. by $3.50 \mathrm{~m}$.

deep (the back wall span is $5.10 \mathrm{~m}$.). Much of the early

Christian fabric is preserved in the lateral walls, apse and

cupola of the present chapel. A double order of windows

in the apse provided light, but the upper windows were

walled in; since the masonry of the windows matches

that of the apse, Edwards (Lewis) suggests that this was a pentimento operation during the first phase of 
construction. ${ }^{232}$ Beneath the chapel was a crypt-like area, inaccessible but visible through a grate or fenestrella confessionis, which enclosed the tomb of the martyr. Initially this was just a subterranean cavity. A fifth century sarcophagus at one time held the remains of the two saints and stairs were added to the crypt in the ninth century; ${ }^{233}$ the present crypt dates to the seventeenth century. Like his Mauritanian compatriots, Nabor and

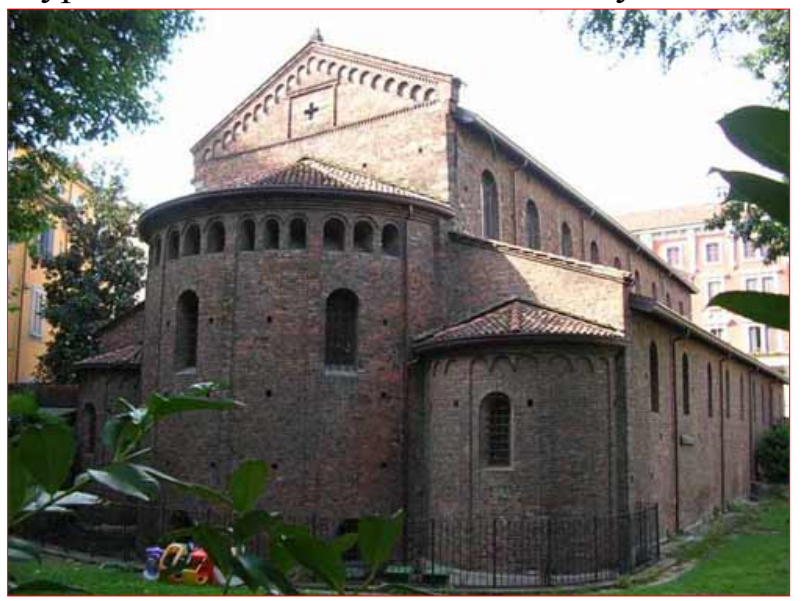

Felix, Victor was brought from Lodi and buried in the Coemeterium ad Martyres. The Acts of St. Victor say that he was exhumed by Bishop St. Maternus (died ca. 340) and reburied, presumably in the chapel that was dedicated to him. This would place its construction safely in the first half of the fourth century.

The church of S. Vincenzo in Prato, located between the Via Vercellina and the Via Ticinensis also had a tradition of pre-Constantinian construction, but the evidence is inferential. During the nineteenth century excavation of the church, the material remains were dated to the eighth century. Castiglioni (seventeenth century) reports the medieval tradition that the site was occupied by a circular temple dedicated to Jupiter, which was subsequently transformed into a basilica dedicated to the Virgin as Sta. Maria in Rotondo, and finally given over to the honor of St. Vincent in the eighth century. ${ }^{234}$ However,

Figure 26: Milan: S. Vincenzo in Prato, east side

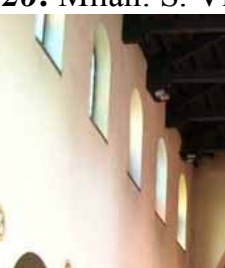


Augustine mentions the cult of the Spanish saint (Augustine, Sermo 296, iv) and St.

Vincent was included in the Ambrosian canon. Edwards (Lewis) suggests that the interior of the three-aisled basilica, similar to the ancient churches of S. Clemente and Sta. Sabina in Rome, betrays its fourth century antecedents in the flat timber ceiling, the schola cantorum flanked by two ambos, and the rhythm of the colonnade. Additionally, the columns have capitals which indicate a variety of origins, including Roman. ${ }^{235}$

Traveling east and due south of the city, two very ancient foundations are identified as being possibly fourth century. The martyrdom of St. Celsus was commemorated by a church (the present day S. Celso) which is noted in the pilgrim guide Itinerium Salisburgense, dating from the seventh century. ${ }^{236}$ Additionally, the church of Sta. Eufemia was located directly north of S. Celso; nothing exists of the early Christian fabric in the present day fifteenth century church, but it is of interest because St. Eufemia is a rare Eastern saint who figures in the Ambrosian liturgical canon. The church of $\mathrm{S}$.

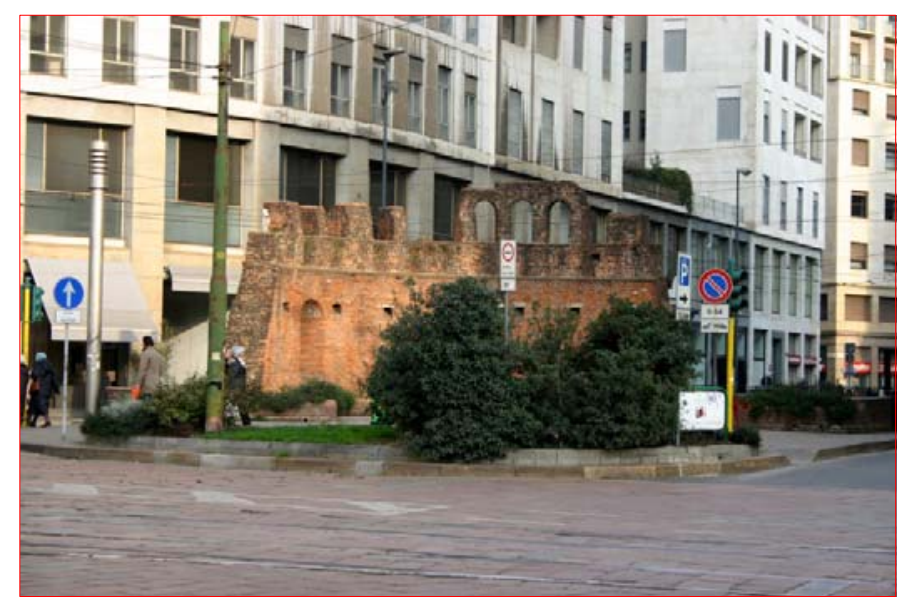

Fiaure 28: Milan: The remains of S. Giovanni in Conca
Calimero was supposedly the burial site of Bishop St. Calimerus, who was buried "in ecclesia sua; ${ }^{237}$ however, there is no mention of this church before the ninth century and it is not included in the Itinerium

Salisburgense. Two other very ancient churches lay further north and east which might have had fourth century beginnings, but are more likely fifth century. S. Stefano in Brolo

\footnotetext{
${ }^{235}$ Edwards (Lewis), "Two Critical Aspects of Fourth-Century Architecture at Milan," 96.

${ }^{236}$ Edwards (Lewis), "Two Critical Aspects of Fourth-Century Architecture at Milan," 99.

${ }^{237}$ Edwards (Lewis), “Two Critical Aspects of Fourth-Century Architecture at Milan,” 100.
} 
(now dedicated to St. Zaccaria) may have been founded by Bishop Matronius in 433, but nothing remains of its original structure. Additionally, within Maximian's walls near the Porta Romana, a very old church that is associated with the sepulchre of Bishop St. Castricianus (third century) appears in the most ancient Catalogus of Milan: S. Giovanni in Conca. Although this church was demolished in 1949, the discovery of early Christian masonry precipitated its complete excavation. However, there is no evidence that this church existed prior to the fifth century, and Calderini believes that it was probably built at the beginning of the seventh century, during the period of the conversion of the Lombards during the reign of Queen Theodolinda, perhaps juxtaposed with the small martyrial oratory of St. Castricianus. ${ }^{238}$

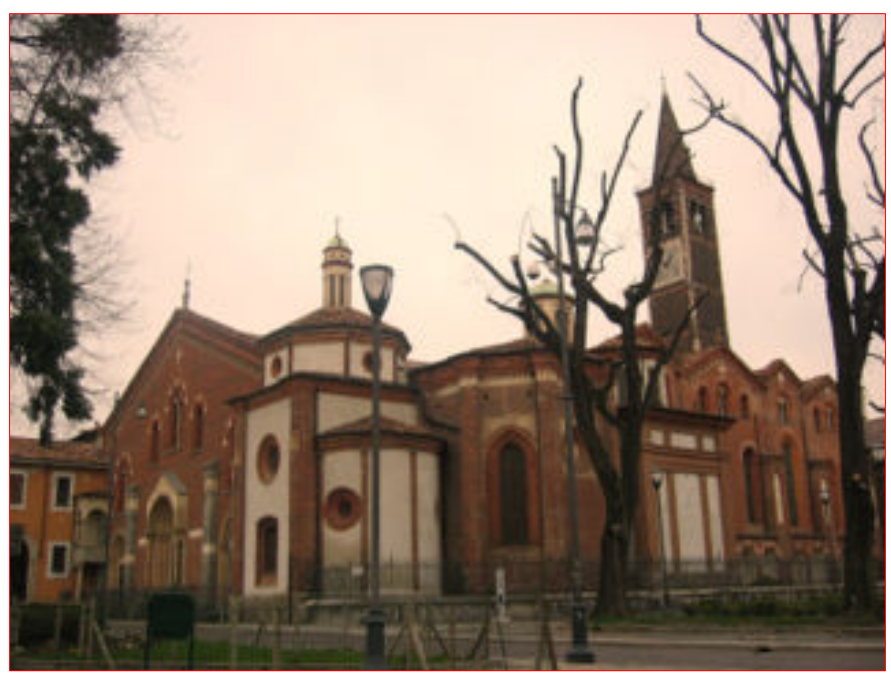

Figure 29: Milan: Sant'Eustorgio (front and right sides)
Due south of S. Lorenzo on the Via Ticinensis, tradition credited the Basilica Sant' Eustorgio as the ancient seat of the Christian community in Milan, built by St. Eustorgius to house the relics of the Magi; however, its earliest inscription is from $461 .^{239}$

While some scholars have identified this church as the Portiana, ${ }^{240}$ the archeological remains, which are fragmentary, suggest that the church was probably built in the sixth

\footnotetext{
${ }^{238}$ Edwards (Lewis), "Two Critical Aspects of Fourth-Century Architecture at Milan," 109.

${ }^{239}$ Edwards (Lewis), "Two Critical Aspects of Fourth-Century Architecture at Milan,” 98.

${ }^{240}$ Edwards (Lewis), "Two Critical Aspects of Fourth-Century Architecture at Milan,” 98. Namely Schuster, based upon Ambrose's allusion to "hereditatem Eustorgi confessoris" in his Sermo contra Auxentius de basilica tradendis justifying his occupation of the Portiana. Montrasio (Le basiliche
} 
century by Bishop Magnus (518-530). The present church, a late Romanesque reconstruction, was restored in the nineteenth century.

preambrosiane, Milan, 1940) has argued that the church was too remote (400 meters south of S. Lorenzo) to be either the palatine church or a suburban congregational church. 


\section{CHAPTER IV}

\section{THE AMBROSIAN LITURGY}

The liturgical rites of the Exarchate of Milan that bear St. Ambrose's name were not actually associated with him in the literature prior to the eighth and ninth century. An Irish writer, $c a .700$, speaks of Ambrose as the author of some "offices" (Spelman, Concilia, tom. i. p. 177). ${ }^{241}$ Walafridus Strabo, the Abbot of Reichenau, who died in 849 wrote, "Ambrose, bishop of Milan, appointed for his own church, and for the rest of Liguria, the arrangements of the liturgy and other offices, which are preserved even to this day in the church of Milana (Walfridus Strabo, de Rebus Ecclesiasticis, xxii)."242

It is important to remember that it was during the fourth century that the great rites of Jerusalem, Antioch, Alexandria, and Rome coalesced to form canons. ${ }^{243}$ Liturgy was, in fact, still in a state of becoming. The guidance of the Apostles ${ }^{244}$ and especially St. Paul, the local traditions of the various churches, the ambitions of the patriarchies, imperial ceremonial, all were sources for the richness and the drama of the spectacle that became the means by which the central mystery of the Christian faith was re-enacted.

\footnotetext{
${ }^{241}$ Palmer, Origines Liturgicae 07, Vol. I: Dissertation on Primitive Liturgies, Sect. VIII, The Canterbury Project http://anglicanhistory.org/palmer/palmer7.html (accessed March 7, 2008).

${ }^{242}$ King, p. 296. "Ambrosius quoque Mediolanensis episcopus, tam Missae quam caeterorum dispositionem officiorum, suae Ecclesiae et aliis Liguribus ordinavit, quae et usque hodie in Mediolanensi tenetur Ecclesia."

${ }^{243}$ Dix, The Shape of Liturgy, 304.

${ }^{244}$ It was during this period that the Apostolic Constitutions were compiled (though not, probably, by St. Clement I to whom their compilation is attributed). The treatises, which are purported to come directly from the Twelve Apostles to the compiler, were intended for the guidance of the clergy. They have immense historical value in their reflection of the moral and religious issues of the third and fourth centuries, as well as their instructions on liturgical practice.
} 


\section{Early Liturgical Sources}

Liturgy, as it developed in the Christian Church, very clearly represented the corporate actions and responsibilities of each of the orders of worshipers as they attempted to reverence and communicate with God. Writing to the Corinthian church, ca. 96, St. Clement of Rome made this very clear:

"Unto the high-priest [which was the bishop-celebrant] his special liturgies have been appointed, and to the priests [the presbyters] their special place is assigned, and to the levites [the deacons] their special deaconings are imposed; the layman is bound by the ordinances of the laity. Let each of you, brethren, make eucharist to God according to his own order, keeping a good conscience and not transgressing the appointed rule of his liturgy." $(1 \text { Clement xl. } 41)^{245}$

The nascent churches of Christianity developed their liturgies as they had been instructed by the Apostles who founded them, centering their focus on the Eucharist, which had somehow to be worked into the existing framework of their Jewish experience. Each church was a corporate member within the body of the Church, enjoined by Peter to be "a holy priesthood to offer up spiritual sacrifices acceptable to God through Jesus Christ." ${ }^{246}$ But each church developed its own local traditions, largely predicated on its understanding of the Old Testament directions for worship, and more importantly, upon its own custom. ${ }^{247}$ As Dix notes, Christian churches were developing a liturgy around the re-enactment of Christ's last formal supper with his chaburrah (the dining association of brotherhood common to Jewish society) at least twenty years prior to the writing of the first New Testament documents. ${ }^{248}$ And while the New Testament writings make reference to the enactment of the Eucharist, it is theologically rather than liturgically.

\footnotetext{
${ }^{245}$ Dix, The Shape of Liturgy, 1.

${ }^{246} 1$ Peter 2:5.

${ }^{247}$ Dix, The Shape of Liturgy, 3. Dix notes that the authority of custom prevailed in the West until the $16^{\text {th }}$ century, when the command of positive law began to supersede local practice.

${ }^{248}$ Dix, The Shape of Liturgy, 3.
} 
There are no directions because the documents take that aspect for granted. For nearly a century before the authority of the canon of the New Testament documents was institutionalized, Christians performed liturgy within the context of the Old Testament, a collection of books that envisioned the center of all human life as played out on the altars of sacrifice on the Temple Mount (but which effectively prevented the infiltration of pagan accretions to the theology of the Pauline account of Christ's institution of the Eucharist). ${ }^{249}$ What is most interesting is that by the time the great rites of Antioch, Jerusalem, Alexandria, and Rome appear in the fourth century, they are remarkably the same in their essential shape (even in the content and arrangement of the Eucharistic prayer), and remarkably different in other aspects. Dix contends that the scholarship which has predicated an ancient proto-liturgy of apostolic institution has missed the point. Only the shape of the liturgy, in its re-enactment of the Eucharist, represents an apostolic tradition. The rest is local. ${ }^{250}$ In the very early Church, liturgy was a matter "of unwritten tradition, left largely to the immediate and extemporaneous inspiration of celebrants. $^{, 251}$

The discovery of the document On the Apostolic Tradition (dated ca. 200) at the beginning of the twentieth century ${ }^{252}$ vastly expanded our understanding of the development of liturgical rites. Although attributed to the third century antipope Hippolytus (d. ca. 236), Alistair Stewart-Sykes has postulated that the work is the production of two authors of a Roman school associated with Hippolytus, the first writing

\footnotetext{
2491 Corinthians 11.

${ }^{250}$ Dix, The Shape of Liturgy, 5.

${ }^{251}$ Massey H. Shepherd, Jr., "The Formation and Influence of the Antiochene Liturgy," Dumbarton Oaks Papers, V. 15, 1961, 23.

${ }^{252}$ Shepherd, "The Antiochene Liturgy," 24. By two scholars working independently: E. Schwartz (1910) and R. H. Connolly (1916).
} 
to address the issues that arose with the development of the monepiscopate controversy that divided the Roman see between Callistus and Hippolytus, while the second added interpolations which reflected the position of the unified see that emerged from this administrative quagmire. ${ }^{253}$ This document, which derives from the usage of Rome, represents the only pre-Nicene document from the Western Church which delineates the liturgy, but its influence can be seen in the canonical rites of not only Rome, but Egypt as well; some of its formularies ${ }^{254}$ are still in use in Coptic and Abyssinian churches. ${ }^{255}$ The book begins with the ordination of bishops (leading the other liturgical headings since this was the issue that was dividing the Roman see), and continues with the constitution of the hierarchy of presbyters and deacons. It then describes how the church should be entered, the catechumenate, rites of initiation and baptism, and the Eucharist, the communion of the faithful. It also provides both prayers and directions for a variety of actions: receiving communion at home, duties of caring for the cemetery, when it is appropriate to pray, and the signing of the cross.

Massey Shepherd, Jr., however, notes that the Anaphora (Consecration prayer) is Antiochene Syrian, which Shepherd posits as the source of all of the Eastern rites. ${ }^{256}$ Antioch's pre-eminence as the first city of Christianity cannot be disputed: it was there that Peter had his first "chair,"257 it was to Antioch that Paul returned again and again to report, and it was in Antioch that the disciples of the new religion first disassociated

\footnotetext{
${ }^{253}$ Hippolytus, On the Apostolic Tradition, ed. Alistair Stewart-Sykes (Crestwood, NY: St. Vladimir's Seminary Press, 2001), 49.

${ }^{254}$ A collection of writings or a book which details liturgical procedures.

255 Shepherd, "The Antiochene Liturgy," 27.

256 Shepherd, "The Antiochene Liturgy," 30.

${ }^{257}$ Shepherd, "The Antiochene Liturgy," 30, citing the reference in Galatians 2:11. Origen was the first to refer to Peter as the "Bishop of Antioch" (Hom. in Luc. vi), and the Decretum Gelasianum, which derives from Pope Damasus I's Roman Synod (382) refers to Antioch as a "see of Peter."
} 
themselves from Judaism and began to call themselves Christian. ${ }^{258}$ The first canonical gospel, the Gospel of St. Matthew, was probably written in Antioch. ${ }^{259}$

The Didache, which is the earliest source ${ }^{260}$ of the Syrian church, remains problematic. The recension, found in 1875 in the Patriarchal Library of Jerusalem in Constantinople, is a Greek edition which includes the letters of Clement; it was probably copied in Egypt in the middle of the second century, and betrays the Hellenization of the Egyptian compiler, which was the only place that considered it canonical. ${ }^{261}$ Nevertheless, its liturgical directions and formularies are consonant with Syrian practice, particularly in the prayers which derive from the beracha, the Jewish benedictions. However, the third century Didascalia did not refer to it, and the editor of the fourth century Apostolic Constitutions was apparently working with a copy that contained the Egyptian interpolations. ${ }^{262}$

Dix notes that, though the author of the Didache was familiar with the Gospel of St. Matthew and the institution of the Eucharist, the liturgy of parts nine and ten is the liturgy of the agape meal, not the Eucharist. ${ }^{263}$ The Apostolic Tradition also distinguishes between the two different meals: the agape meal is a private liturgy of fellowship among friends, while the Eucharist, served by the bishop, is a communal meal of the corporate body of the Church. ${ }^{264}$ What is important, however, is that both the

\footnotetext{
${ }^{258}$ Shepherd, "The Antiochene Liturgy," 30.

259 Shepherd, "The Antiochene Liturgy," 31.

${ }^{260}$ A very ancient manuscript containing the Teaching of the Twelve Apostles. It originated in Antioch and was known to Eusebius, Athanasius, Clement of Alexandria and Origen. It contains treatises on baptism, the Eucharist, and church organization. This document has been dated as early as 70 and as late as 160 . Most scholars safely place it between the last decade of the $1^{\text {st }}$ century and first two decades of the $2^{\text {nd }}$ century.

${ }^{261}$ Shepherd, "The Antiochene Liturgy," 33.

262 Shepherd, "The Antiochene Liturgy," 33.

${ }^{263}$ Dix, The Shape of Liturgy, 92.

${ }^{264}$ Dix, The Shape of Liturgy, 93.
} 
Apostolic Tradition and the Didache stress that both meals are sacred and are not to be shared with the uninitiated: in the Apostolic Tradition we find, "Let no one eat or drink of your eucharist but those baptized in the Name of the Lord"265 while the Didache quotes Matthew 7:6, "Give not that which is holy unto the dogs.",266

The earliest recension of the Didascalia Apostolorum, written ca. 250, is also a Syrian document; both the Didache and the Didascalia have been incorporated in their entirety into the fourth century Apostolic Constitutions (c. 375), ${ }^{267}$ from which the fullyformed Eastern rites (the Jerusalem rite of St. Cyril, St. Basil's Liturgy of St. James, the Antiochene Litugy of St. John Chrysostom and the Byzantine rite of Constantinople) ultimately emerged.

For a view of the living liturgy as it was enacted, the non-patristic sources include numerous journals of pilgrimages to the Holy Land, of which two, the Itinerarium Burdigalense (333) ${ }^{268}$ and the Itinerarium Egeriae (late fourth century, perhaps $381-383)^{269}$ are representative of fourth century peregrination. Of the two accounts, the account by Egeria, a Christian woman who spent several years in the Near East traveling to sacred sites which she described in a letter for her close friends (whom she calls "sisters") at home, is especially valuable. The account that we have is an incomplete eleventh century copy of the original from Monte Cassino (Arezzo, Library of the Fraternity of St. Mary, MS 405); it lacks the beginning, the end, and several chapters

\footnotetext{
${ }^{265}$ Hippolytus, The Apostolic Tradition, ix, 5.

${ }^{266}$ Dix, The Shape of Liturgy, 93.

${ }^{267}$ See note 244.

${ }^{268}$ The author is anonymous. Since the journey begins in Bordeaux, he is known as the Bordeaux Pilgrim. The journey took place during the period of the joint consulship of Flavius Dalmatius and Domitius Zenophilus.

${ }^{269}$ Hagith Sivan, "Who Was Egeria? Piety and Pilgimage in the Age of Gratian," The Harvard Theological Review, V. 81, 1 (Jan. 1988), 59, citing Paul Devos, "La date du voyage d'Égérie,' AnBoll 85 (1967) 16594.
} 
of the body. Hagith Sivan has convincingly argued that Egeria was probably a woman of more than sufficient means (though not an aristocrat, more likely a wealthy, urban bourgeoise), a layperson associated with a group of pious women, perhaps from the Gallic port of Arles; ${ }^{270}$ however, John Wilkinson continues to promote her Galician origin, given Theodosius' Spanish background. ${ }^{271}$ Egeria's account of the liturgy of the patriarchy of Jerusalem, and especially the paschal liturgy of the celebration of Easter, is particularly valuable as she contrasts it with the liturgy with which she is familiar in the West.

\section{The Ambrosian Rite}

Two possible theories exist to account for the Eastern anomalies of the Ambrosian liturgy. As mentioned above, Eusebius spoke of Greek missionaries from Ephesus to Gaul. ${ }^{272}$ Greek and oriental ideas could have entered through the ports of Classis and Aquileia which traded heavily with the largely Greek populations of the Adriatic. The major port of Antioch at Seleucia-Pieria was also an important intermediary of communication and trade between East and West, and Hellenistic influences were also possible from contacts with Sirmium and Salonika.

While it is true, as we shall see, that Ambrose did introduce some innovations to the liturgy, it is important to remember that he came to the episcopacy as a secular civil

\footnotetext{
${ }^{270}$ Sivan, "Who was Egeria," The Harvard Theological Review, 65, 71-72. Egeria has traditionally been identified as a Spanish (Galician) nun writing for the benefit of the sisters of her monastic order. The source of this identification was a late $7^{\text {th }}$ century letter by the Spanish monk Valerius to a monastic community in Galicia in which he incorporates portions of Egeria's journal as examples of appropriate piety and devotion. Unlike the Bordeaux Pilgrim's journal, the loss of the opening chapters leaves Egeria without identity or homeland. However, her leisurely travel itinerary and the duration of her pilgrimage, her confidence and her ability to command assistance, and her lack of any asceticism all militate against the probability of her having been a religious associated with a monastic house. She makes one geographical reference to the Rhone River; Sivan infers Arles as her starting point as the only port on the Rhone.

${ }^{271}$ John Wilkinson, Egeria's Travels: Newly Translated with Supporting Documents and Notes by John Wilkinson (Warminster: Aris \& Phillips, 2002), introduction.

${ }^{272}$ See page 44.
} 
servant. His predecessor, Auxentius, was a Cappadocian who had held the see for nearly twenty years. Duchesne believes that Ambrose would have had little inclination to change the liturgical traditions and practices which he found in place, other than to purge them of any heretical (Arian) references. ${ }^{273}$ He also believes that the rite was essentially Eastern (that is, Antiochene Syriac) ${ }^{274}$ introduced either through Aquileia, ${ }^{275}$ or, more likely, as the legacy of the Cappadocian Auxentius. ${ }^{276}$ From Milan, the canon spread to Gaul and eventually became the Gallican rite, now extinct. ${ }^{277}$ Duchesne's theory gains credence when we see that of the two Byzantine rites, the Liturgy of St. Basil and the liturgy of St. John Chrysostom, that of St. Basil was based upon the liturgy of Caesarea, in Cappadoccia. Shepherd notes that it is exactly comparable to the Antiochene liturgy and was probably introduced to Constantinople by Gregory of Nazianzen. ${ }^{278}$

The other theory suggests that the rite retained the archaic elements of a Greek proto-liturgy, which was common to both Rome and Milan in the second century. The language of the liturgy was Greek until Latin was substituted in the middle of the third century/early fourth century. ${ }^{279}$ King, therefore, while not denying that the Ambrosian

\footnotetext{
${ }^{273}$ Duchesne, Christian Worship, 95, e. g., Arian bishops were known to re-baptize.

${ }^{274}$ Dix, The Shape of the Liturgy, 541. Dix notes that Bishop Eusebius of Milan (451-465) was a Greek from Syria. It is a tradition of the Milanese Church that Eusebius was responsible for the rebuilding of churches throughout northern Italy following the devastation of the Gothic invasion, and for renewing their service manuals, which were burned. This raises the interesting possibility that the Ambrosian liturgy should more accurately be called the Eusebian liturgy. However, citing Cantù, Milano e il suo territorio, I, 116 is the additional information that Bishop St. Simplician, Ambrose's successor, also added to the rite and Bishop St. Lazarus (438-451), the predecessor of Bishop Eusebius, added the three days of the Litanies.

${ }_{275}$ Duchesne, Christian Worship, 94.

${ }^{276}$ Duchesne, Christian Worship, 93.

${ }^{277}$ Duchesne, Christian Worship, 91.

${ }^{278}$ Shepherd, "The Antiochene Liturgy" 39.

${ }^{279}$ Theodore Klauser, A Short History of the Western Liturgy: An Account and Some Reflections, trans. John Halliburton (London: Oxford University Press), 1969, 19. Liturgists continue to use the Greek terms in describing the separate elements of the liturgy, and Greek terminology continues to be familiar to congregations today, most notably as they recite the Kyrie and communicate during the sacrifice of the Eucharist.
} 
liturgy has many Eastern anomalies, asserts that the majority of liturgists hold that the rite was originally Roman ${ }^{280}$, taking on its Eastern character slowly through the centuries as a result of a variety of circumstances. ${ }^{281}$ In the early pre-Ambrosian period, he points to several possibilities: Arian bishops who settled in the West, Milan's early fourth century bishops, several of whom were Greek, ${ }^{282}$ the long sojourns of Western bishops attending councils in the East, as well as the long tenure of Auxentius. ${ }^{283}$ If we accept Pope Innocent I's statement that all bishops in Italy were spiritually, liturgically and episcopally descended from the hierarchy of Rome by virtue of St. Peter's foundation of the see, ${ }^{284}$ then it is indeed possible that the conservatism of the provincial capital held on to its archaic, Eastern practices.

\section{Liturgical Practice in Milan}

Christian liturgy, however, does not exist solely in the vacuum of the symbolic and the literary. It has a dynamic facet which is played out in the performance of its participants, the different orders of bishop, presbyters, deacons, and laity, and a setting upon a stage where its drama is realized and re-enacted, Sunday after Sunday, service after service. Until the third century, the word ecclesia (church) meant only the solemn assembly of the faithful for the liturgy. ${ }^{285}$ It is not until the Peace of Constantine at the beginning of the fourth century that this term began to be applied to the building which

\footnotetext{
${ }^{280}$ King, Liturgies of the Primatial Sees, 299. He cites Probst, Ceriani, Magistretti, Pope Pius XI, Cardinal Schuster, and Msgr. Bernareggi.

${ }^{281}$ King, Liturgies of the Primatial Sees, 296.

${ }^{282}$ As already noted, the first bishop of Milan, St. Anatolius, was Greek. Bishop St. Dionysius, the bishop exiled to make way for Auxentius, died in exile in Cappadocia, suggesting that he too may have been Greek and perhaps Cappadocian as well.

${ }^{283}$ King, Liturgies of the Primatial Sees, 297.

${ }^{284}$ See above, note 188.

${ }^{285}$ Dix, The Shape of Liturgy, 19.
} 
enclosed the sacred space that accommodated the liturgy. ${ }^{286}$ It is this aspect, the movement of the participants, that is the most elusive of liturgical studies, and it is the function of this aspect that is most intimately entwined with the development of church architecture.

But it is difficult to determine what the fourth century practice of the liturgy was; Ambrose took seriously the injunction not to betray the central mysteries of the faith (the disciplina arcani), and even in the writing of his sacramental treatises, was careful to be ambiguous. $^{287}$

The mystery should remain sealed with you...that it be not divulged to those for whom it is not meet, that it be not spread among the unbelieving by babbling loquacity.

(Ambrose, De mysteriis, 55)

Beware lest you incautiously divulge the mysteries of the Creed or the Lord's Prayer...Cherish the deep mysteries in your own breast; do not by premature speech commit them to the ears of the unbelieving or the weak, lest the hearer be repulsed and shrink from them in horror.

\section{(Ambrose, De Cain, I, 37)}

It is good to hide the mystery of the King; for he sins against God who thinks that the secret mysteries entrusted to him should be published to those who are unworthy of them. So it is dangerous, not only to speak what is false, but also to speak what is true, if one speak it to those to whom it ought not to be spoken...If any one divulges the treasure of God to the Babylonians, he will be guilty of a great offence... Beware, then, that you do not betray your riches to the unbelieving; even if they pretend friendship, do not open to them the interior parts of your house, do not disclose the King's treasures, which the Babylonians ought not to know. This is the meaning of the Lord's saying in the Gospel, 'Cast not your pearls before swine.'

(Ambrose, Expositio in psalma cxviii, 2. 26-8)

\footnotetext{
${ }^{286}$ Dix, The Shape of Liturgy, 19.

${ }^{287}$ Dudden, St. Ambrose, 453.
} 
The challenge of recreating the liturgy as it was performed in fourth century Milan is further complicated by the fact that the earliest Ambrosian liturgical documents in the Bibliotecca Ambrosiana are tenth century, although Duchesne makes the case that the late seventh century Gallican sacramentary known as the Bobbio Missal (Bibliothèque Nationale, Paris, No. 13, 246) should be taken as a guide to Ambrosian practice. ${ }^{288}$ His early insistence on the evolution of the Gallican liturgy from the Ambrosian liturgy has received new credence in the issue of the critical analysis of that manuscript edited by Hen Yitzak and Rob Meens, where the analysis points to "the principal doctrinal assertions of the Missal's liturgy,"289 i.e., anti-Arian and anti-Pelagian positions and an emphasis on the cult of the saints. However, as much as possible, the analysis of this paper will rely on the clues that Ambrose himself offered, with inferences drawn from known practice.

\section{Missa catechumenorum}

In Milan, services of psalmody (what became the Offices) ${ }^{290}$ were offered daily, in the morning, about mid-day (when it preceded a celebration of the Eucharist), in the evening, and finally as a night vigil. Augustine speaks of his mother attending Mass daily, and that she additionally 'resorted' to the church in the morning and the evening. ${ }^{291}$ The morning service included the Beatitudes of the Sermon of the Mount, and the singing of the psalms was interlaced with the recitation of the Lord's Prayer. Ambrose wrote:

\footnotetext{
${ }^{288}$ Duchesne, Christian Worship, 158.

${ }^{289}$ Alison Fraser, "Reconsidering an Enigmatic Bobbio Codex (Paris, BN, MS Lat. 13246), H-Net Reviews, September 2005 of The Bobbio Missal: Liturgy and Religious Culture in Merovingian Gaul, eds. Hen Yitzhak and Rob Meens (New York: Cambridge University Press, 2004), http://www.h-net.msu.edu/reviews/showrev.php?id=11136 (accessed September 19, 2008).

${ }^{290}$ Dix, The Shape of Liturgy, 329. The singing of the Divine Office begins with Cyril of Jerusalem (Egeria noted the complete daily round of offices in the 380's, shortly before Cyril's death in 386). Ambrose's troubles with the Empress Giustina precipitated his use of the Office (see below), which was continued in Milan.

${ }^{291}$ Augustine, Confessions, v. 9.
} 
In the morning hasten to the church and bring the first-fruits of your prayer: thus, if afterwards secular business claims you, you will still be able to say, mine eyes prevent the morning, that I might be occupied in the words, and you will proceed with safety to the transaction of your affairs. How pleasant it is to begin the day with hymns and canticles, with the Beatitudes which you read in the Gospel! How propitious that the words of Christ should bless you, and that while you repeat the Lord's benedictions, you should become eager for the acquirement of one or another virtue, so that even in your own self you may recognize the power of the Divine benediction!

(Ambrose, Expositio in psalma cxviii, 19. 32)

And further, “...Join psalms in frequent interchange with the Lord's Prayer." ${ }^{, 292}$ The use of the Lord's Prayer, both here and in the Canon of the Eucharist, was in itself unusual in the West. Dix notes that, while the Lord's Prayer does not appear in either the rite of the Apostolic Constitutions or the Antiochene rite of Chrysostom (late fourth century), it is found in Cyril of Jerusalem's rite (348). ${ }^{293}$ Early in the fifth century, Augustine wrote in a letter that "almost the whole world now concludes" the Eucharistic prayer with the Lord's prayer, ${ }^{294}$ the exception being Rome, which did not adopt it until the pontificate of Gregory I (ca. 595). ${ }^{295}$ Ambrose refers to it again as placed within the body of the Eucharistic Prayer, followed by the Doxology and Great Amen (De sacramentis, vi. 24) (395). ${ }^{296}$ In this, the Ambrosian liturgy continued to differ from the eventual practice of Rome, which placed it immediately after the Canon and before the Fraction. ${ }^{297}$

\footnotetext{
${ }^{292}$ Ambrose, De Virginibus, iii. 19.

${ }^{293}$ Dix, The Shape of Liturgy, 131.

${ }^{294}$ Augustine, Epistolae, 59.

${ }^{295}$ Dix, The Shape of Liturgy, 131.

${ }^{296}$ De sacramentis is a series of six catechetical lectures that were delivered to the newly initiated Christians during the Octave of Easter, beginning on Tuesday and ending Sunday, possibly 390 or 391 but prior to 392 when Ambrose wrote De instituione virginis ad Eusebium, which draws on the earlier work. The scholarship has always been divided on its Ambrosian attribution. As late as 1914, when the Catholic Enclyclopedia was published, the work was still attributed to pseudo-Ambrosius, and Dudden remained doubtful. The more recent scholarship has returned it to the Ambrosian corpus. Ambrose's explanation of the Lord's Prayer required an entire chapter of his fifth catechetical lecture, and is of interest to liturgists as a topic about which $4^{\text {th }}$ century patristic literature is almost silent.

${ }^{297}$ Dix, The Shape of Liturgy, 131.
} 
Sunday mass, for Ambrose, was celebrated in the cathedral complex. ${ }^{298}$ The service began with the Ingressa, the entrance procession. Unlike the Little Entrance of the Eastern Church, the bishop did not lead the procession. ${ }^{299}$ He was, instead, preceded by first, the laity taking their places in the church, and second, the orderly procession of the hierarchy of his clergy, beginning with the most lowly (the doorkeepers), and proceeding through the ranks of exorcists, lectors, presbyters and deacons, all chanting the Introit. ${ }^{300}$ The deacon carrying the Gospel walked immediately ahead of the bishop, in the place of honor. He was preceded by acolytes bearing thuribles with burning incense, and lighted torches. ${ }^{301}$

Although incense was used in the Roman churches from the period of the Edict of Milan, it was used more as a way of introducing fragrance into the church. Ambrose is credited with the sacramental use of incense as an oblation ${ }^{302}$ and the practice of censing the altar, which was also considered an archaic practice, since it stemmed from Judaic practice in the Temple of Jerusalem that had been revived by Cyril of Jerusalem. ${ }^{303}$ Cyril's use of incense may have always been a fixture in the Jerusalem church, but in the West during the period of the persecutions, when the test of burning incense before a

\footnotetext{
298 See note 386 for the usages of the two cathedrals.

299 Thomas F. Mathews, The Early Churches of Constantinople: Architecture and Liturgy (University Park, PA: The Pennsylvania State University Press, 1971) 140.

${ }^{300}$ Duchesne, Christian Worship, 190.This psalm, which became an antiphon, was especially chosen to dignify the procession.

${ }^{301}$ Dix, The Shape of Liturgy, 414. Paulinus of Nola mentions this custom in a poem c. 400; Dix estimates that the practice had been in place for at least twenty-five years prior to this. It was a blatant co-opting of the custom of imperial procession, which mandated that the emperor and his family be preceded by retainers bearing lights and incense.

${ }^{302}$ Ambrose, De Cain et Abel, I, v. 19.

${ }^{303}$ Dix, The Shape of Liturgy, 351.
} 
pagan altar was used to reveal Christians, the use of incense in the church was actually viewed with hostility. ${ }^{304}$

The Ingressa into the church was meant to be holy, profound, and impressive. With the bringing in of the Gospel, and its solemn deposition on the altar, Christ was now present, and when the bishop took his place, he became the representative of Christ, the absolute successor to the Apostles. ${ }^{305}$ At this point, it might be useful to stop the action and look at the disposition of the different orders.

Architecturally, the Apostolic Constitutions specify that the congregational area of the church should be oblong shape: "The church must be long in shape and must face east; in this way it resembles a ship (Apostolic Constitutions, 2, 57, 3 F). ${ }^{306}$ The injunction to "face east" posed a problem, since if the front of the church faced east, the congregation had to turn to face the door in order to pray in the manner that was hallowed from the mists of antiquity, facing east. "Orienting" the church on an east-west axis with the front door at the west end solved this problem.

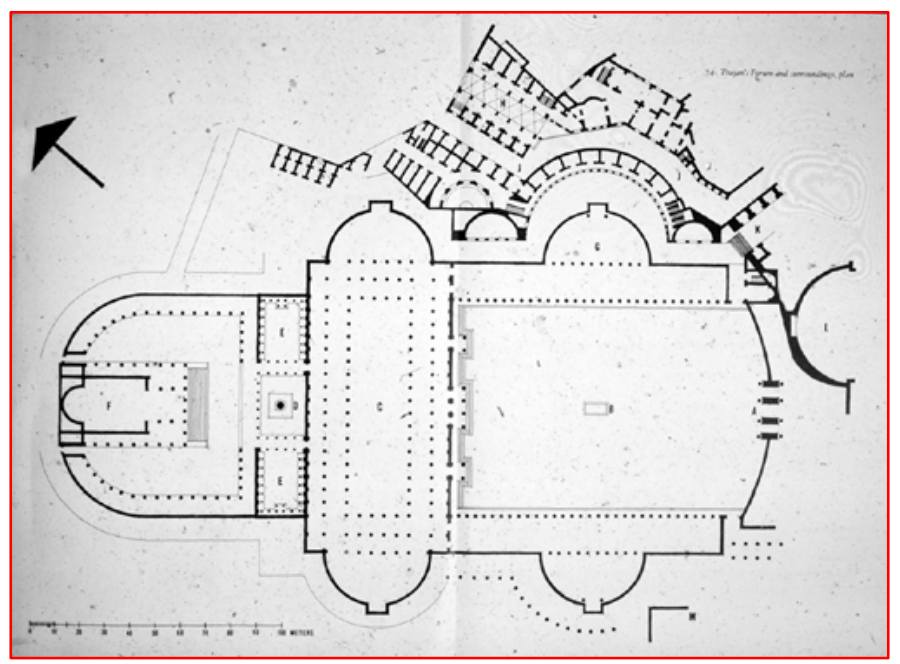

However, the adoption of the basilical form of Roman architecture by early Christianity for the ecclesia required a lengthening of the longitudinal axis of a building type that did not

Figure 30: Rome, Plan of the Forum of Trajan, 98-128

\footnotetext{
${ }^{304}$ Dix, The Shape of Liturgy, 426.

${ }^{305}$ Dix, The Shape of Liturgy, 31, citing Hippolytus, Philosophumena, i. I: "Being found successors of the apostles, and partakers with them of the same grace of high-priesthood and the teaching office, and reckoned watchment of the church."

${ }^{306}$ Klauser, A Short History of the Western Liturgy, 143.
} 
actually have a longitudinal or processional character. The Roman basilicas frequently opened on a forum, were entered from the side, and had aisles which surrounded the interior so as to produce a centralized effect. ${ }^{307}$ The lengthening of the longitudinal axis of the building served to promote the liturgy of the Ingressa (Little Entrance), as well as the subsequent processions of the liturgy.

The procession was enhanced by the fact that the central area of the nave, which provided the space for procession, was raised slightly (the solea); Krautheimer has demonstrated that in S. Tecla the solea ran the full length of the nave to the chancel barrier. $^{308}$ The chancel area (from the Latin cancellus, a low screen), which was also raised, continued the longitudinal axis into the apse, where a series of raised benches (the synthronon), curving into the apse, provided seating for the clergy. The trajectory of the

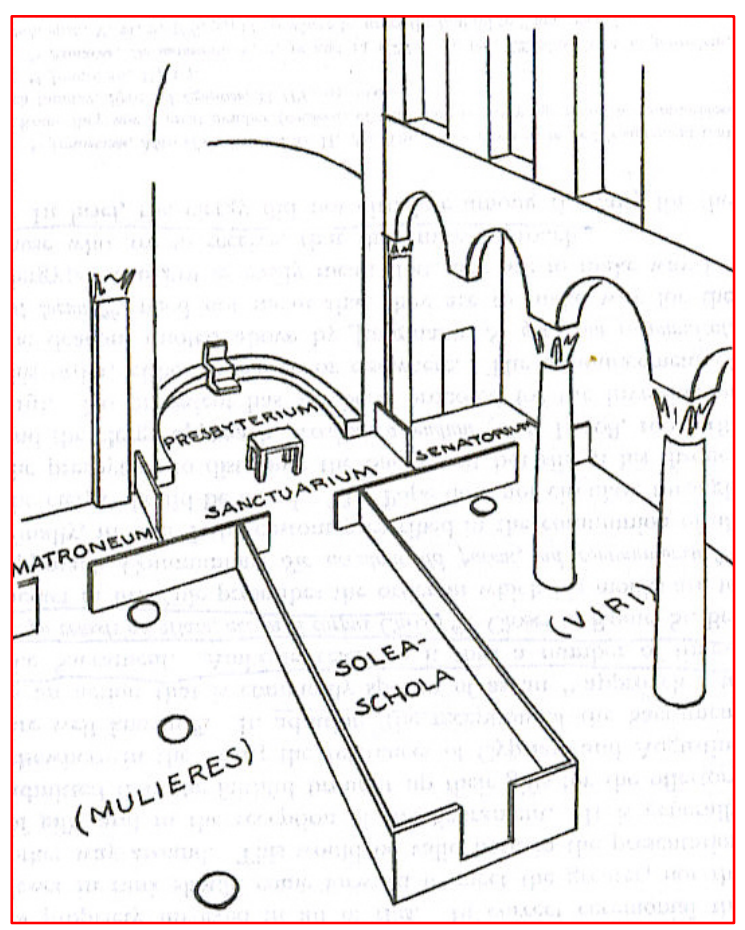

axis was punctuated by the sanctuary of the altar, which, placed forward toward the barrier, formed the focus of the chancel between the barrier and the presbyterium of the synthronon.

Normally, the bishop would take his place on his throne (cathedra) in the apse with his clergy ranged about him. However, this was not the case in Milan. It was

Figure 31: An early Christian chancel arrangement (after Mathews)

\footnotetext{
${ }^{307}$ Mathews, "An Early Christian Chancel Arrangement," Rivista di Archeologia Cristiana, V. 38, 1-2 (1962), 82.

${ }^{308}$ Krautheimer, Three Christian Capitals, 77.
} 
Ambrose's wish that small thrones for the bishop and the emperor should be placed "in front of the bounds of the holy altar," i.e., on either side of the sanctuary. ${ }^{309}$ This replicated the custom in Jerusalem in which a similar disposition of the bishop's and emperor's throne was used. ${ }^{310}$ We do not know who had which side; however, Mathews' reconstruction of the Byzantine liturgy of Constantinople placed the emperor on the south side of the church. ${ }^{311}$ Additionally, the Ambrosian predilection for the north corner of the altar (as seen below) suggests that the north side was sacerdotal.

The Milanese Church apparently conformed to the ancient usage of aisled Roman basilicas. The central area of the nave, including the length of the axis, represented a sacred space reserved for the ceremonial aspects of the service: the action of the two services and processions and movement of the clergy. The congregation stood in the arcaded aisles of the basilica. However, how strictly they were held within the aisles is not clear. In fifth century Constantinople, Mathews has shown that the congregation spilled into the nave to reverence the Gospel. ${ }^{312}$ The Testamentum Domini (a fifth century Syrian source) assigned the south aisle to the men of the congregation, and the north aisle to the women. ${ }^{313}$ There is no indication of whether the congregations of Milan were segregated by sex, only that they occupied the aisles. ${ }^{314}$

\footnotetext{
${ }^{309}$ Spiro Kostof, The Orthodox Baptistery of Ravenna (New Haven: Yale University Press,1965), 81, citing Sozomen, Historia Ecclesiastica, iii, 25.

${ }^{310}$ Kostof, The Orthodox Baptistery of Ravenna, 81.

${ }^{311}$ Mathews, Early Churches of Constantinople, 134.

${ }^{312}$ Mathews, Early Churches of Constantinople, 125.

${ }^{313}$ Suzanne Lewis, "Function and Symbolic Form in the Basilica Apostolorum at Milan," Journal of the Society of Architectural Historians, 28, 1969, 96.

${ }^{314}$ There is a teasing reference, however, which the author has misplaced, of the men and women who occupied the Portiana alternating their parts in the singing of the antiphon. This could indicate that the sexes were normally divided within the church, or that they were divided for the sake of propriety during their occupation of the Portiana over a period of several days.
} 
We have a curious incident from Sozomen (Historia ecclesiastica, vii. 25$)^{315}$

repeated by Theodoret (Historia ecclesiastica, v. 18). ${ }^{316}$ Theodosius, in residence in Milan after the defeat of Maximus, attended Mass at the cathedral (ca.390/391; the Emperor did not make public penance for Thessalonica until Christmas 390 and was an excommunicate until April 391). At the point where the Offertory procession began, the Emperor went forward and presented his offering and remained standing within the sanctuary to receive communion. Apparently, this was the custom that prevailed when the Emperor communicated in Constantinople. But it was not the custom in Milan, where the Emperor was expected to lead the congregation to communion. The bishop, having inquired about the Emperor's presence in the sanctuary, refused to follow the Eastern practice. He sent an archdeacon with the message, "The priests alone, Sir, are allowed to remain within the sanctuary. Depart, therefore, and stand with the rest of the laity. The purple makes princes, not priests." ${ }^{317}$ Considering the rocky relationship that Theodosius and Ambrose had, it is surprising that the Emperor not only obeyed his bishop, but apparently did not resent it. Theodoret informs us that he continued to follow the Milanese custom even after he had returned to Constantinople (Theodoret, Historia Ecclesiastica, v. 18). Church law was on Ambrose's side: the Council of Laodicea (368) was clear that only sacred ministers could enter the sanctuary, while a separate canon of

\footnotetext{
${ }^{315}$ McLynn, Ambrose of Milan, 298.

${ }^{316}$ Dudden, St. Ambrose, 392.

${ }^{317}$ Dudden, St. Ambrose, 392, my emphasis. According to Eusebius, in the few days left to Constantine after his baptism, the emperor "resolved never to come in contact with purple again." (Eusebius, Vita Constantiniis, iv. 66) However, imperial privilege was re-asserted after his death, when his soldiers laid him in a golden casket which they wrapped in purple cloth, and when the embalmed body was displayed in Constantinople, it was arrayed in the diadem and purple robe. Ambrose's remark is anachronistically ironic, since the color purple was gradually adopted for the clergy (Kreider, "Changing Patterns of Conversion in the West," 21).
} 
that council forbade women from entering the sanctuary of the altar. ${ }^{318}$ However, the nave was not so restricted.

The service now began with the deacon enjoining silence. The noisiness of the congregation, particularly in the missa catechumenorum when the scriptures were sung and the bishop preached his sermon, was a continuing source of clerical exasperation. "What a work there is in church to procure silence when the lessons are read!" (Ambrose, In psalma 1 enarr. 9) ${ }^{319}$ It should be remembered that during this portion of the service, anyone was welcome, even those who were not Christians. But chatter in church appeared to be an endemic problem. Ambrose recalled Pope Liberius' remarks when, in the ceremony of the solemn veiling of Ambrose's sister Marcellina to perpetual virginity, he rebuked the congregation for their noisiness:

Very great is the virtue of silence, particularly in church. Let no sentence of the divine lessons escape you; and, if you give ear, restrain your voice. When any passage is read in which Christ is announced as coming [the prophetic lesson] or is shown to have come [the Epistle and the Gospel] refrain from talking and making a noise, and pay attention. Could anything be more unbecoming than that the divine oracles should be drowned in a din, so as not to be heard, believed, or made known; that the sacraments should be celebrated amid a confused babble of voices, so that the prayer which is offered for the salvation of all is hindered? Do you at the Mystery [the recital of the Canon] abstain from groaning, clearing the throat, coughing, laughing.

$$
\text { (Ambrose, De virginibus, iii. 11-14) })^{320}
$$

When a relative quiet had been achieved, the bishop greeted his congregation, conforming to the usage of Rome with Dominus vobiscum and the congregation (laity

\footnotetext{
${ }^{318}$ Mathews, The Churches of Constantinople, 123. One wonders why the Council felt it had to reiterate this point with a separate canon for women, since women could never be sacred ministers. Presumably, the Council was directing its attention to deaconesses, whose role must have been necessarily limited.

Alternatively, it could have been an indication of the established Church's suspicion of women, which became institutionalized; a far cry from the nascent, persecuted Church's perception and use of women. ${ }^{319}$ Dudden, St. Ambrose, 448.

${ }^{320}$ Dudden, St. Ambrose, 448.
} 
and clergy) responded, and the Gloria in excelsis and a triple Kyrie were sung. ${ }^{321}$ The bishop now called his lectors forward for the reading of the lessons (the Prophecy from the Old Testament and the Epistle from the Apostles), between which additional psalms were sung. The lessons finished, the chief deacon then began the second solemn procession for the reading of the Gospel. In Milan, this ceremony was performed with as much solemnity as the Ingressa had been, though far fewer people were involved. The deacon first received the bishop's blessing to retrieve the Gospel from the altar, after which he elevated the Gospel and moved through the sanctuary to the north side and around to the front of the altar. The deacon was accompanied by two acolytes with

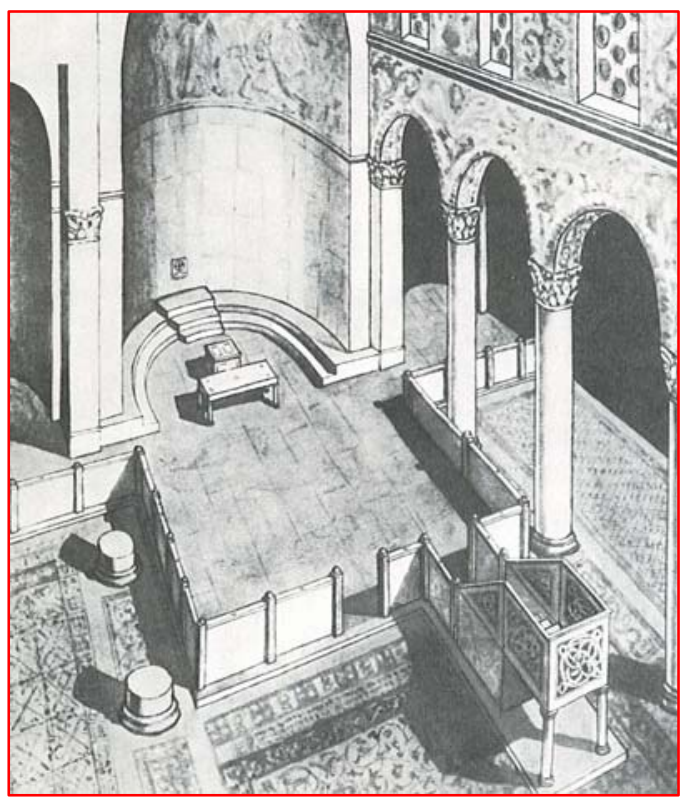

Figure 32: Gerasa: SS Peter and Paul, early Christian chancel with ambon $\left(5^{\text {th }} \mathrm{c}\right.$.) incense. There is no mention of candles; Jerome, writing in 406 , felt he needed to explain this aspect of the Eastern Church's Gospel procession. ${ }^{322}$ An additional acolyte supported the Gospel during the reading, which was sung, and the name of Jesus was prefixed with "Lord." 323 One peculiarity of the Ambrosian practice (and there is no indication when it was started) is the stationing of two

\footnotetext{
${ }^{321}$ Duchesne, Christian Worship, 190-191. During Lent, two litanies were alternated in place of the Gloria, resembling the Great Synapte (litany) of the Syrian Church, sung by the deacon with the congregation's response of Kyrie eleison (Lord have mercy). The very ancient Kyrie actually has preChristian antecedents (appearing as an exclamation in the Old Testament); in the New Testament, the sources are Matthew, Mark, and Luke. It appears in the $8^{\text {th }}$ book of the Apostolic Constitutions, but the earliest mention of it in the patristic literature is from St. John Chrysostom. However, Egeria mentioned hearing it sung in Jerusalem (XXIV, 5). It was not adopted in Rome until Gregory I added it, when it was amended with the Christe eleison (late $6^{\text {th }}$ century). The Gloria was a Roman import.

322 Thomas F. Mathews, "Early Christian Chancel Arrangement," 85, citing Jerome, Contra vigilatium, 23. 361.

${ }^{323}$ Dudden, Ambrose, 449.
} 
deacons at the north and south ends of the altar during the reading of the Gospel. When the reading was finished, the triple Kyrie was again sung, while the deacon ceremonially processed the Gospel back to the altar.

It should be noted that there is no ambon in Mathews' reconstruction of the early Christian chancel (Figure 31). Mathews points out that there is no way to know when this feature of early Church architecture appeared, although in the African church, Augustine and Cyprian both refer to the structures called pulpitum and tribunale. ${ }^{324}$

Following the Gospel, the bishop preached his sermon. ${ }^{325}$ As noted above, Ambrose routinely preached on Sundays, on festivals, and daily during Lent. ${ }^{326}$ Although he occasionally gave his permission to allow presbyters to preach, Ambrose restricted this privilege to experienced men, believing that young clergy should refrain for the sake of modesty. ${ }^{327}$ The bishop had very definite ideas about how a homily should be constructed: it should be simple, dignified, lucid, and possessed of common sense, neither too elaborate, nor too unpolished. ${ }^{328}$ The preacher should use plain language, because his listeners were mostly uneducated people. ${ }^{329}$ It should not be too long, because people get bored, but it should not be too short either, because then it fails to make an impression. ${ }^{330}$

Preaching was absolutely the bishop's responsibility, and the bishop normally spoke to his congregation while sitting on his throne (ex cathedra). ${ }^{331}$ Theologically and

\footnotetext{
${ }^{324}$ Mathews, "Early Christian Chancel Arrangement," 86.

325 See note 131 for the topics of Ambrose's sermons.

${ }^{326}$ Dudden, Ambrose, 449.

${ }^{327}$ Dudden, Ambrose, 449 citing Ambrose, Expos. psalma cxviii, 15.14.

${ }^{328}$ Ambrose, Expos. psalma cxviii, 2. 26.8; De officiis, i, 101; Epistolae, ii.5.

329 Ambrose, De Isaac, 57.

${ }^{330}$ Ambrose, De officiis, i, 104.

331 The Church continues to define the Pope's teaching on doctrine as either ex cathedra (at which point it is authoritative and becomes dogma) or not.
} 
liturgically, this reinforced the dual nature of a bishop's ordination that had been outlined by Hippolytus: "Being found successors of the apostles, and partakers with them of the same grace of high-priesthood $a n d^{332}$ the teaching office, and reckoned watchmen of the church (Hippolytus, Philosophomena, i. 1). ${ }^{„ 333}$ In remaining seated during the synaxis (the liturgy of the Word) and the homily, the bishop represented his teaching and prophetic function, speaking to the congregation with God's voice. When he stood at the altar to perform the Eucharist, he assumed his role as high-priest, speaking for the people as he articulated their prayers, and acting for God as he consecrated and administered the Eucharist. In effect, he had become a two-way conduit between God and His people.

In Rome, however, the homily appears to have become moribund. The Ordo I (the liturgical directive of Rome) makes no provision for it, and Sozomen (before 450) remarked that at Rome, neither the bishop nor anyone else preached. ${ }^{334}$ Roman priests were not authorized to preach, and the Pope did not appreciate other bishops granting this privilege. Only Pope St. Leo I and Pope St. Gregory I have left collections of homilies; those of St. Leo are very short and appear to have been composed for festivals. ${ }^{335}$

At the conclusion of the missa catechumenorum, everyone who had not been initiated into the Mystery (i.e., baptized), including the catechumens, was dismissed by the doorkeepers in very stern terms and the clergy processed out. There was a break here in the time sequence of the service; how long it was is not clear. We know that Ambrose used this interval to speak to Emperor Theodosius about the Callinicum affair (388), ${ }^{336}$

\footnotetext{
${ }^{332}$ My emphasis

${ }^{333}$ Dix, The Shape of Liturgy, 31.

${ }^{334}$ Sozomen, Historia ecclesiastica, vii. 22.

${ }^{335}$ Mathews, "Early Christian Chancel Arrangement," 86.

${ }^{336}$ Ambrose, Epistolae, xx. 4. In Callinicum, a city on the Euphrates about 150 miles from Antioch, a Christian gang of monks, led by their bishop, plundered and destroyed the local synagogue. When

Theodosius received the report of the affair, he viewed it as a matter of local discipline, and ordered his
} 
on Palm Sunday, the interval was quite long because the bishop went to the baptistery to give instructions on the Creed to the catechumens who would be baptized the following week during the Easter vigil. ${ }^{337}$ In Milan during Ambrose's tenure, penitents were permitted to attend the missa fidelium, even if they had not completed their penance and were still excluded from communicating. ${ }^{338}$ The cathedral of Milan possessed neither narthex nor galleries, so there was no segregation of penitents or catechumens such as Mathews posits for the galleries and nartheces of the churches of Constantinople, which would have facilitated their exit. ${ }^{339}$ Presumably, the congregants gathered their offerings for presentation during the missa fidelium during this period. Following the interval between the services, the Mass of the Faithful would begin with the Great Entrance of the clergy and the Offertory.

\section{Missa fidelium}

The ceremony began once again with the injunction by the doorkeepers to maintain silence and to watch the doors, so that no profane person might enter. ${ }^{340}$ The altar, which was a simple table of wood, perhaps covered with a stone slab, ${ }^{341}$ was bare,

comes orientis to punish the criminals, making sure that the bishop bore the fiscal responsibility for the rebuilding of the synagogue. Ambrose remonstrated with the emperor, in this instance, very clearly supporting the institutional Church in the protection of the bishop against the civil authority. He pointed out that Christians were enjoined not to support any activity associated with the Jews, and suggested that the bishop might refuse, and choose martyrdom instead. Theodosius rescinded his order against the bishop. Dudden deplores Ambrose's intervention in this event, as revealing Ambrose as both a bully and a bigot, but McLynn's analysis demonstrates that Ambrose's agenda had less to do with a group of fanatical Syrian monks than it did with establishing a relationship with the emperor and the inner recesses of the emperor's court (McLynn, Ambrose of Milan, 298-309).

${ }^{337}$ Ambrose, Epistolae, i. 2.

${ }^{338}$ Dudden, St. Ambrose, 450. The Church's position on penance has evolved ideologically through the centuries, one might say radically, as indicated by the fact that it is now known as the Sacrament of Reconciliation. In Ambrose's time, serious sins required serious penance that might last several years, and even a lifetime.

${ }^{339}$ Mathews, The Churches of Constantinople, 129.

${ }^{340}$ Duchesne, Christian Worship, 204.

${ }^{341}$ Peter Friedrich.Anson, Churches, Their Plan and Furnishings (Milwaukee: Bruce Publishing, 1948), 60, 62. Anson notes that early Christians avoided using the term "altar" because of its associations with 
without the adornments of candles, crosses, or reliquaries that were added later. King avers that the rite of prothesis, the Eastern Church's complicated and lengthy rite of sanctification of the oblation (a private ceremony performed by the celebrant before the beginning of the missa catechumenorum), was never a part of the Milanese liturgy. ${ }^{342}$ However, in the sixth century Gallican rite, Duchesne speaks of the clerical preparation of the Elements, which are already referred to as the Body and Blood of Christ, and notes that this preparation took place before the procession of the clergy which begins the Eucharistic mass (the Mozarabic Missal contains extensive directions), which must have been in the interval. ${ }^{343}$ I think that we can infer that some preparation of the Elements was performed, and that they were carried in great state during the Great Entrance of the clergy at the beginning of the missa fidelium.

However, if the Milanese preparation of the Offertory was not as elaborate as was done in the Eastern Church, it also did not conform to the practice of the Roman Church either. In the Roman mass, prior to the missa catechumenorum, the congregational offerings were given to the deacons who placed them on the tables in the sacristy. The deacons then processed from side aisles with the offerings to special tables that were placed to the side of the main altar. Duschene believes that the Milanese followed the Eastern practice of the Great Entrance with the ceremonial presentation of the gifts of offerings, which had been selected by the deacons, but Ambrose says at one point that the baptized were permitted to offer their gifts at the altar, the emperor (if in

paganism, preferring some form of "the table of the Lord." In the $4^{\text {th }}$ century, the Christian altar still retained its integrity as a table.

${ }^{342}$ King, Liturgies of the Primatial Sees, 419.

${ }^{343}$ Duchesne, Christian Worship, 204. 
residence) leading them. ${ }^{344}$ Augustine reiterates this point: "the priest receives from thee that which he may offer for thee." (Augustine, In psalma cxxviii. enarr. 7) From what I can divine, the Great Entrance of the Milanese Church processed with the deacons bearing the prepared and veiled Elements to the altar, where the bishop-celebrant would take up his position, facing the people, who now followed their bishop in bringing their offerings to the altar. ${ }^{345}$ A pure linen veil was also brought in to cover the altar and the Elements were triply veiled as in the Eastern Church. ${ }^{346}$ The veils that covered the oblations of the chalice and paten were very richly made, perhaps of jeweled silk, a third veil covered both of them together on the altar and they were all blessed with special prayers at the altar. The veils were not transparent, because they were meant to hide the Elements. During the procession, a chant similar to the Byzantine Cheroubikon, the exultation of the angels, was sung, followed by the Alleluia. ${ }^{347}$ The newly baptized were not permitted to offer their gifts until the Octave of Easter a week later. This was because they were still receiving catechetical instruction from Ambrose. ${ }^{348}$

The Canon of the Eucharist in the Milanese Church began with the deacon calling for the Kiss of Peace (a divergence from the Roman form where the Kiss occurs after the Canon), ${ }^{349}$ the deacon warning, "Let none keep rancor against any! Let none

\footnotetext{
${ }^{344}$ Ambrose, Expositio in psalma cxviii, 2.

${ }^{345}$ Dudden, Ambrose, 450. The curious practice of the offering of the Vecchioni da Scuola di Sant'Ambrogio, which forms such a distinctive part of the present day Milanese liturgy, is a $10^{\text {th }}$ century addition. Ten widowers and ten widows, specially costumed, bring the Offering to the altar where it is received by the deacons. Dudden believes that it is a commemoration of the Offertory of the people to which Ambrose alludes.

${ }^{346}$ Mathews, Churches of Constantinople, 139. For some reason, Mathews only refers to two veils.

${ }^{347}$ Duchesne, Christian Worship, 205.

${ }^{348}$ Dudden, Ambrose, 430.

${ }^{349}$ Dix, The Shape of Liturgy, 107. The Kiss of Peace was an ancient adaptation of Jewish social practice, drawing as its source Isaac's blessing of Jacob and Jacob's reconciliation with Esau. In the African Church, it remained connected to the Lord's Prayer. This connection was severed in the Western Church. See also Duchesne, Christian Worship, 213: from a letter written by Pope Innocent to Decentius at the
} 
give the peace in hypocrisy! ${ }^{, 350}$ and the reading of the diptychs which today constitutes the Prayer of the Faithful followed by the great litany of the saints. Many of the saints in the Milanese litany are local to Milan or found special reverence in Milan (Victor, Nabor, Celsus, Felix, Calimarus, Vitalis, Vincent), while some come from the Eastern Church (Andreas, Euphemia, Justina, Sabina, Tecla, Pelagia and Catharine). The present litany also includes the early Milanese bishop-saints (with Ambrose, of course), and St. Martin of Tours.

The celebrant then began the Eucharistic Prayer; we know that during the prayer the celebrant kept his hands stretched out, forming the shape of a cross. ${ }^{351}$ This prayer is a prayer of thanksgiving, which is offered by the celebrant on behalf of the people, and Ambrose makes this clear in his catechesis: "All the other things which are said in the earlier part [of the prayer] are said by the priest - praises are offered to God, prayer is asked for kings, for the people and the rest; [but] when it comes to the consecration of the venerable sacrament, the priest no longer speaks in his own name, but he uses the words of Christ," (Ambrose, De sacramentis, iv. 4. 14). Ambrose does not mention the use of the Sanctus liturgically, which formed the natural conclusion to the thanksgiving portion of the prayer in the Antiochene rite, ${ }^{352}$ although there is a hint of it in a quote from De spiritu sanctu: "Cherubim and Seraphim with unwearied voices praise Him, and say, Holy, Holy, Holy is the Lord God of Sabaoth" (Ambrose, De spiritu sanctu,

beginning of the $5^{\text {th }}$ century, it is clear that the practice of giving the Kiss prior to the Consecration was in full observance throughout northern Italy.

${ }^{350}$ Dix, The Shape of Liturgy, 107.

${ }^{351}$ Dudden, Ambrose, 452. Ambrose alludes to this position in his work De virginibus, i. 7, speaking about St. Agnes at the heathen altars stretching out her arms to form the shape of a cross. This is not the orantes position that we see in catacomb art, but the arms raised and fully extended.

${ }^{352}$ Dix, The Shape of Liturgy, 539. 
iii, 110), which is exactly the Antiochene form, including the addition of "God" (i.e. Lord God of Sabaoth), a Syrian interpolation. ${ }^{353}$

Ambrose says the action of the priest during the Consecration could not be seen by the congregation ${ }^{354}$ and the question arises as to why it was not visible. The Western churches may have used the structure of the templon, an architectural device that surrounded the altar with a ciborium of columns and curtains that was a feature common to early Byzantine churches, ${ }^{355}$ but it did not develop the later iconostasis of the Eastern Church, which effectively concealed the altar from the congregation architecturally in a closed sanctuary. However, the excavation reports for S. Tecla do not provide any evidence for the foundations necessary for the columns which would have supported a templon. ${ }^{356}$ Krautheimer, in his discussion of the typology of the fifth century churches of the Aegean coastlands, which he acknowledges drew on the architecture of the Milanese churches, ${ }^{357}$ notes that the aisles of these churches were separated from the nave by a screen of columns, parapets and curtains, which effectively prevented the congregation from seeing the action of the celebrant at the altar. As such, it is possible that curtains were hung between the columns of S. Tecla which would have hidden the altar from the congregation. Ambrose mentioned

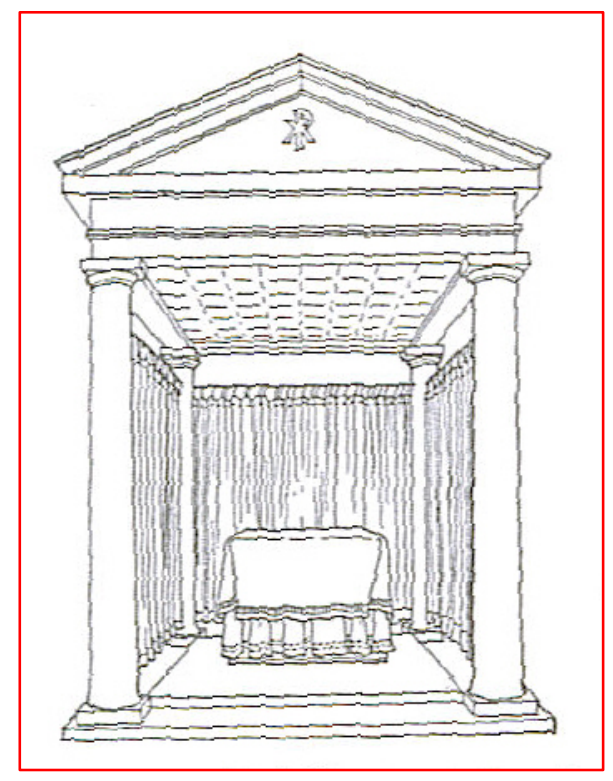

Figure 33: Early Christian templon and altar

\footnotetext{
${ }^{353}$ Dix, The Shape of Liturgy, 539.

${ }^{354}$ Ambrose, De officiis, i. 250.

${ }^{355}$ Mathews, Churches of Constantinople, 163.

${ }^{356}$ Edwards (Lewis), "Two Critical Aspects of Fourth-Century Architecture at Milan," 104.

${ }^{357}$ Krautheimer, Early Christian and Byzantine Architecture, 97.
} 
in his letter to his sister on the battle for the Portiana that the people removed the royal hangings, which he sadly said were "torn by children in their play,"358 but he may have been referring to hangings associated with the imperial family. However, Mathews has shown that the custom of concealing the liturgy of the Eucharist is not supported archeologically in early Byzantine churches. He therefore asserts that the concealment of the liturgy was accomplished through the veiling of the Elements. ${ }^{359}$ His argument, liberally supported by documentary as well archeological sources, makes sense intuitively. There would have been no reason to conceal the altar, since everybody present was baptized, initiated in the mysteries. However, the words and action of the Consecration are restricted to the liturgy of priests alone; as St. Clement indicated, ${ }^{360}$ the liturgies of each order cannot overlap.

The celebrant proceeded with the rinsing of his hands in a basin held for him by a deacon, and continued with the Consecration, reciting the words from the Gospel of

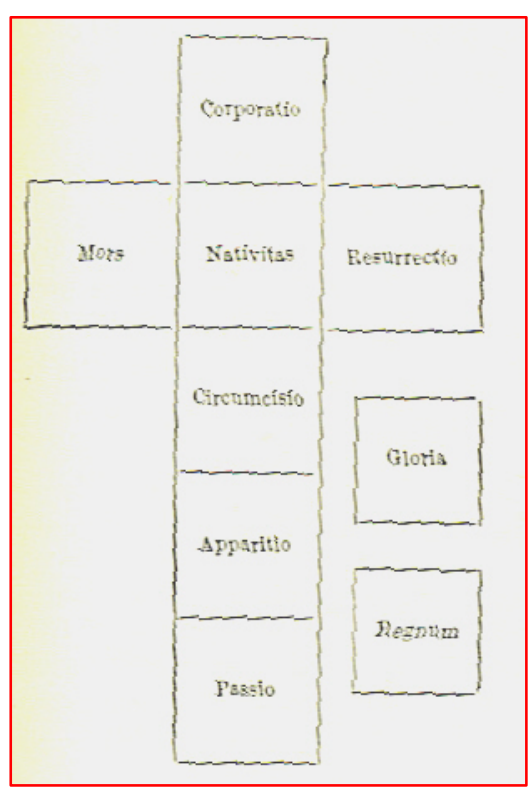
Christ's Institution of the mystery of the sacrifice. There was no elevation, nor were there any ringing of bells; these are much later additions to the Roman mass, but were not (and are not) included in the Milanese mass. However, the Fraction was a complicated affair, requiring that the celebrant to arrange the broken Body in a pattern on the paten. It can not be denied that a certain amount of superstition had crept in with the

Figure 34: Fraction of the Host $\left(6^{\text {th }}\right.$ c. $)$

\footnotetext{
${ }^{358}$ Ambrose, Epistolae, xx.

${ }^{359}$ Mathews, Early Churches of Constantinople, 171.

${ }^{360}$ See page 69 above.
} 
Fraction; Duchesne points out that the Gallican church was in the habit of arranging the pieces of the Host in the shape of a man. ${ }^{361}$ This practice was denounced by the Council of Tours (567), which specified that the celebrant should make an arrangement in the form of a segmented cross, each segment of which represented some aspect of Christ's life (Figure 34). ${ }^{362}$

Ambrose's clergy "adored" the Host when it had been consecrated, presumably after the practice of the Eastern Church, with prostrations. ${ }^{363}$ Sometime in

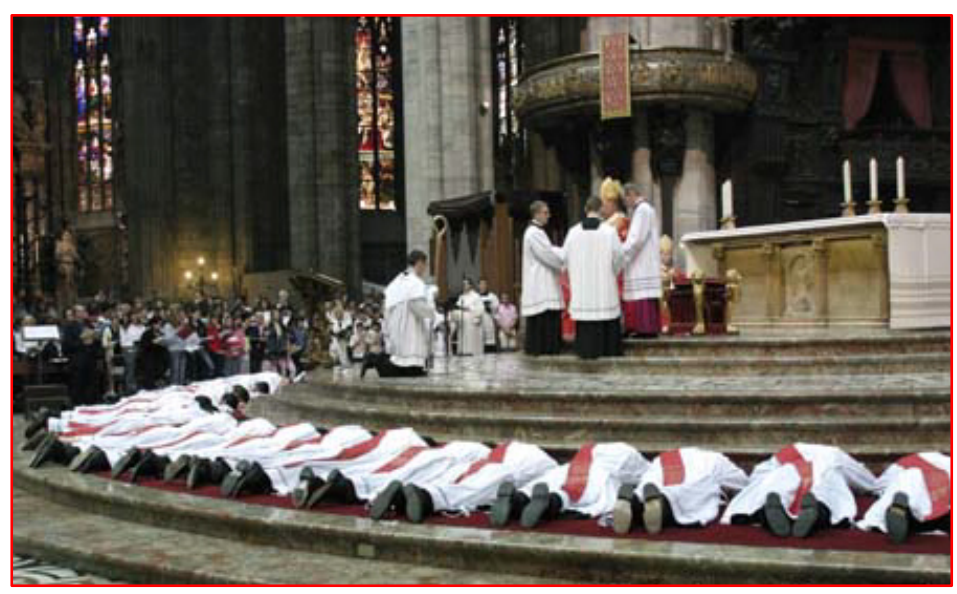

the subsequent centuries in the evolution of the Ambrosian liturgy, the clergy developed the curious practice of filing past the altar and kissing the north corner of it after they had

Figure 35: Milan: 2005 Ordination of Priests at the Cathedral

received communion. In searching for a parallel, both the Eastern and the Roman Churches appear to have had some ceremony which involved kissing the Gospel at the conclusion of the reading. In the fifth century Byzantine rite, the book was paraded by the deacon to allow the laity to reverence it with a kiss or a touch, ${ }^{364}$ and in the seventh century pontifical mass of Rome, the deacon carried the book to the clergy to kiss. ${ }^{365}$ There is also the veneration of the Cross in St. Cyril's Rite of Jerusalem, which Egeria describes. However, my personal feeling of this strange addition to the liturgy of Milan,

\footnotetext{
${ }^{361}$ Duchesne, Christian Worship, 219.

${ }^{362}$ Duchesne, Christian Worship, 219.

${ }^{363}$ Ambrose, De spiritu sanctu, iii. 79.

${ }^{364}$ Mathews, Churches of Constantinople, 125.

${ }^{365}$ Mathews, "Early Christian Chancel," 82.
} 
given the stubbornness of the archdiocese to preserve its local practice (as is noted below), is that it represents a clerical commemoration of the great saint-bishop of Milan, whose throne was positioned on the north side of the altar.

When the clergy had been fed, the people formed another procession and approached the altar ${ }^{366}$ for their communion, which they received standing. ${ }^{367}$ If the emperor was in residence, he led them. They received under both species, and the Body was placed in their hands; $;{ }^{368}$ both Theodoret ${ }^{369}$ and St. Cyril verify this. Cyril's catechesis is very specific:

So when you come forward, do not come with arm extended or fingers parted. Make your left hand a throne for your right, since your right hand is about to welcome a king. Cup your palm and receive in it Christ's body, saying in response Amen. Then carefully bless your eyes with a touch of the holy body, and consume it, being careful to drop not a particle of it. For to lose any of it is clearly like losing part of your own body...After partaking of Christ's body, go to the chalice of his blood. Do not stretch out your hands for it. Bow your head and say Amen to show your homage and reverence, and sanctify yourself by partaking also of Christ's blood. While your lips are still moist with his blood, touch it with your hands and bless your eyes, forehead, and other organs of sense.

$$
\text { Cyril of Jerusalem, Mystagogical Catechesis, 5.21-22 } 370
$$

Ambrose used the very simple words of administration, "The Body of Christ," and the people responded, “Amen.”371 During communion a chant was sung, and when everyone had received, another triple Kyrie of thanksgiving was sung. ${ }^{372}$ The deacon then enjoined

\footnotetext{
${ }^{366}$ Ambrose, De Elia, 34.

${ }^{367}$ We can infer this from Paulinus' account of the healing of Nicentius' gouty foot that Ambrose stepped on when he was giving Nicentius communion (Paulinus, Vita Ambrosii, 44.)

${ }^{368}$ Duchesne notes that in the $6^{\text {th }}$ century, the men received bare-handed, but the women covered their hand with a linen cloth, the dominical, which they brought with them for this purpose (Duchesne, Christian Worship, 224).

${ }^{369}$ Dudden, Ambrose, 452, citing Theodoret, Historia Ecclesiastica, v. 18.

${ }^{370}$ Paul F. Bradshaw, "The Effects of the Coming of Christendom on Early Christian Worship," The Origins of Christendom in the West, ed. Alan Kreider (Edinburgh: T \& T Clark, 2001), 274.

371 Ambrose, De sacramentiis, iv. 25.

${ }^{372}$ Duchesne, Christian Worship, 227.
} 
them to bow their heads and receive the blessing of their bishop. The clergy re-formed their processional order and again led their bishop out, after which the people were free to leave the church. Ite, missa est.

Something, of course, is missing. There is no recitation of the Creed in either the liturgy of the catechumens, or the Eucharist of the faithful. It seems an irony that the statement of belief that so agonized the fourth century Church had, as yet, no place in the liturgy of the mass. It had traditionally been used during the ceremonies of initiation of baptism, where it was posed as an interrogatory, requiring the candidate to affirm his belief with his answers. ${ }^{373}$ During the Monophysite ${ }^{374}$ controversy that erupted after the Council of Chalcedon (451), the Monophysite patriarch of Antioch, Peter, began the practice of reciting the Creed in the liturgy as a political statement of adherence to the spirit of the Council of Nicea (473). The Creed continued to be controversial, and its use, political. It was inserted into the rite of Constantinople in 511, a heretical practice that became part of the Byzantine liturgy. In the Western Church, the Apostles' Creed continued to be used in baptism, and it was this creed that Ambrose used in his catechesis. $^{375}$

Some of the other Eastern practices of the Ambrosian rite included the reckoning of Easter (which followed the Eastern Church's computation) and the extension of Lent

\footnotetext{
${ }^{373}$ Dix, The Shape of Liturgy, 486.

${ }^{374}$ The Monophysite heresy was as divisive of the Church in the $5^{\text {th }}$ century as Arianism had been in the $4^{\text {th }}$ century. The controversy concerned the nature of Christ: whether that nature was wholly divine (the Monophysite position) or embodied two aspects, one human and one divine (the orthodox view that was confirmed at the Council of Chalcedon). As in all of the theological debates of the early Church of the $4^{\text {th }}$ and $5^{\text {th }}$ centuries, the devil is in the philosophical ramifications taken to their logical conclusion which were sometimes utterly bizarre. The Nestorian Church is the result of this Christological debate.

${ }^{375}$ Everett Ferguson, "Catechesis and Initiation," The Origens of Christendom in the West, ed. Alan Kreider (Edinburgh: T \& T Clark, 2001), 252-253.
} 
by two weeks, ${ }^{376}$ the elimination of fasting on Saturdays which were always festal,,${ }^{377}$

even in Lent, and certain Old Testament lessons (Job, Jonas, and Tobias) which were

read during Holy Week. ${ }^{378}$ Ambrose's use of the prophetic lessons stemmed from Judaic

practice during Passover and was, therefore, considered archaic. Like the Eastern

churches, the Milanese rite abstained from the celebration of Mass on Fridays in Lent;

Good Friday continues to be celebrated as the true day of the Easter redemption or the

Paschal feast and red vestments are worn instead of the black vestments of the Roman

canon. Although the Roman canon expressly forbade the administration of the sacrament

of baptism on Epiphany (January 6), this feast in the Milanese church, which also

celebrated the miracles of Christ, had special baptismal rites associated with it. ${ }^{379}$ In fact, the feast of Christmas was not celebrated in the ancient Milanese rite (and was a late

addition to the liturgical calendar), and Epiphany took its place. ${ }^{380}$

Ambrose abandoned the multiple Eucharistic formulae of his Arian predecessor, and adopted the more simplified standard Roman prayer, but he retained two exceptions: the masses for Holy Thursday and the Easter Vigil of the Ambrosian missal are archaizine, apparently reflecting the local practice of the churches of Cisalpine Gaul. ${ }^{381}$ In general, the prayers of the Ambrosian rite are more prolix, complex, and sentimental,

\footnotetext{
${ }^{376}$ This practice is also defended by Ambrose (Ambrose, De sacramentis, iii. 5).

${ }^{377}$ McLynn, Ambrose of Milan, 279. Augustine writes that his mother had him ask the bishop why Milan had no Saturday fast (Augustine, Epistolae, 54).

${ }^{378}$ King, Liturgies of the Primatial Sees, 298.

${ }^{379}$ Edwards (Lewis), "Two Critical Aspects of Fourth-Century Architecture at Milan," 76.

${ }^{380}$ Dix, The Shape of Liturgy, 357. Rome began celebrating Christmas in 354, but it had not been accepted in Jerusalem when Egeria visited the city in 385. Alexandria did not adopt the feast until 430. The Eastern Church, which had celebrated the Nativity on Epiphany, now revisited the feast as a commemoration of the manifestations of Christ: the visit of the Magi, His Baptism, and the Miracle of Cana. My own experiences as a child living in northern Italy affirm the relatively quiet celebration of Christmas, a relic of ancient practice, and the anticipation of Epiphany and la Befana.

${ }^{381}$ Edwards (Lewis), "Two Critical Aspects of Fourth-Century Architecture at Milan," 76.
} 
which reflects the spirit of the Eastern rites. ${ }^{382}$ The Milanese rite also contains a remnant from the period of imperial residence in the prayer which invokes divine protection for the emperors and their families. ${ }^{383}$

Ambrose himself found it necessary to defend the Milanese rite. He writes in De sacramentis that he attempted to bring the liturgy into conformance with the Roman practice, ${ }^{384}$ which suggests that he inherited its practice. However, in the same paragraph, he is adamant about retaining the ceremony of foot-washing that was an integral part of the baptismal process.

Yet it [Rome] does not have the custom of washing the feet. So note: perhaps on account of the multitude this practice declined. Yet there are some who say and try to allege in excuse that this is not to be done in the mystery, nor in baptism, nor in regeneration, but the feet are to be washed as for a guest. But one belongs to humility, the other to sanctification...So I say this, not that I may rebuke others, but that I may commend my own ceremonies. In all things I desire to follow the Church in Rome, yet we, too, have human feeling; what is preserved more rightly elsewhere we, too, preserve more rightly.

(Ambrose, De sacramentis, iii. 5)

His defense of local practice is indications of how strongly he, a non-Milanese, had committed himself to the Milanese see.

There is no indication that Ambrose used the practice of fermentum, in which a portion of the Host consecrated by the bishop was distributed to the priests saying mass in other churches. This practice, supposedly introduced by Pope St. Miltiades (311-314), became an important part of the development of Roman stational liturgy. ${ }^{385}$ Milan did, of course, develop a stational liturgy, and it is apparent from his letters that Ambrose

\footnotetext{
${ }^{382}$ Edwards (Lewis), "Two Critical Aspects of Fourth-Century Architecture at Milan," 75.

${ }^{383}$ Edwards (Lewis), "Two Critical Aspects of Fourth-Century Architecture at Milan," 76.

${ }^{384}$ King, Liturgies of the Primatial Sees, 297, quoting Ambrose, De sacramentis, iii. 5: "In omnibus cupio sequi ecclesiam Romanam; sed tamen et nos hominis sensum habemus; ideo quod alibi rectius sevatur, et nos rectius custodimus."

${ }^{385}$ John F. Baldovin, The Urban Character of Christian Worship: The Origins, Development, and Meaning of Stational Liturgy (Rome: Pont. Institum Studiorum Orientalium), 1987, 121.
} 
celebrated mass in different churches. ${ }^{386}$ But the information as to the actual rogations is almost non-existent, and it is possible that the smaller size of Milan and the fewer number of churches would have rendered the use of the fermentum unnecessary.

It is obvious that many of the elements that characterized the Milanese rite were integrated into the Roman rite and vice versa as the centuries passed. However, that the liturgy was distinctively different from the Roman rite is attested to by the determination with which the papacy attempted to bring the northern Italian churches into concordance with the Roman canon, as it evolved after the revisions of Pope St. Gregory I (the Great) in 594. ${ }^{387}$ The papal onslaught to eliminate divergent liturgical practices continued through the centuries, ${ }^{388}$ and was not above enlisting the aid of the Emperor. Charlemagne attempted to impose the Roman rite throughout the west ${ }^{389}$ he was successful in eliminating the Gallican rite in Gaul and the Mozarabic rite in Spain (with two notable exceptions), but the Milanese rite was resolutely preserved by its bishops and its congregations. At the Council of Trent (1545), the papacy finally recognized defeat. The Council's rule of conformance to the Roman rite provided for the exception of practices which could be demonstrated to have been in use for at least two centuries. This exception preserved the Ambrosian rite (which in fact, had become progressively

\footnotetext{
${ }^{386}$ The Catholic Encyclopedia Online, s.v. "Ambrosian Liturgy and Rite," http://www.newadvent.org/cathen/01394a.htm (accessed March 7, 2008). The Bergamo Sacramentary (perhaps $11^{\text {th }}$ century) presumes the existence of two cathedrals in Milan, the very ancient S. Maria Maggiore which was used as the winter church, and S. Tecla, which was used as the summer church. The change-over was made at Easter and at the anniversary of the dedication of S. Tecla in October. The procession of Palm Sunday traditionally began at S. Lorenzo Maggiore (the Portiana) and ended at S. Tecla. The use of the Portiana to initiate this procession would have been entirely consistent with Ambrose memorializing his victory over the Empress Giustina.

${ }^{387}$ King, Liturgies of the Primatial Sees, 304 . The pope approved it on the strength of its association with St. Ambrose.

${ }^{388}$ King, Liturgies of the Primatial Sees, 305. By Pope St. Gregory I who sent St. Augustine to Britain to purge the English of their Celtic practices, by Pope Nicholas II (1059-61) with St. Peter Damian, and by Gregory VII (1073-85).

${ }^{389}$ King, Liturgies of the Primatial Sees, 306.
} 
Roman through the centuries), ${ }^{390}$ the remnants of the Mozarabic rite of Toledo and Salamanca, the Missal of Lyons (all that is left of the Gallican rite), and the canons practiced by some religious orders (the Dominicans, Carmelites, and Carthusians). ${ }^{391}$ Until very recently, the Ambrosian canon was the canon of the northern Italian churches. Today, it is used as a matter of parochial preference. Oddly enough, it has additional scattered usage. Emperor Charles IV introduced its use in the fourteenth century in the Church of S. Ambrose in Prague, and it continues to be used in parts of the Swiss Canton of Ticino. $^{392}$

While the liturgical anomalies are fascinating, it is more important for the purposes of this paper to focus on those aspects of the liturgy that can be associated with St. Ambrose (either as innovated or expanded by him) that required architectural accommodation. Those aspects fall into several broad categories: 1) ceremony and chant, 2) the sacrament of baptism, and 3) the litany of the saints and martyrs, expanded to include the associated cult of the saints.

\section{Ceremony and Chant}

Ambrose's struggle to eliminate the heresy of Arianism from the northern Italian churches ultimately brought him into direct conflict with the imperial family. Following the murder of the Emperor Gratian, the Dowager-Empress Giustina (Valentinian I's relict) moved with her young son, Valentinian II, to the court at Milan (383). Giustina, a recalcitrant Arian, made an early attempt to secure a church for the court which would be Arian, but the bishop repulsed these overtures, and for a period of several months endured a program of harassment initiated by the empress to force his compliance with

\footnotetext{
${ }^{390}$ King, Liturgies of the Primatial Sees, 301.

${ }^{391}$ King, Liturgies of the Primatial Sees, 315.

392 King, Liturgies of the Primatial Sees, 316.
} 
her wishes. However, during Lent of 385, Giustina again demanded a church from Ambrose ${ }^{393}$ specifically the Basilica Portiana, a suburban church that may have been near the palace. ${ }^{394}$ In what is perhaps the first recorded instance of a sit-in demonstration, Ambrose and his congregation moved into the Portiana during Holy Week and refused to leave. Giustina sent her troops to surround the church and to prevent anyone from entering or leaving, but she dared not lay hands on the bishop. By Holy Thursday she was forced to concede defeat. There would be no heretic churches in Milan.

It is fortunate that Augustine was in residence in Milan and had joined Ambrose in his occupation of the Portiana. He wrote:

The pious people kept watch in the church, ready to die with their bishop. Then it was that the custom arose of singing hymns and psalms, after the use of the Eastern parts ${ }^{395}$ lest the people should wax faint through the tediousness of sorrow; and from that day to this the custom has been retained, many, nay, almost all, of the Christian congregations throughout the rest of world following herein.

(Augustine, Confessions, ix. 7) (96 $^{39}$

Paulinus, Ambrose's biographer, also mentions this incident and credits Ambrose with introducing antiphonal chant and metrical hymns to the western usage. ${ }^{397}$ In Ambrose's cathedral, offices of psalmody occurred four times within each twenty-four hour period, in addition to the celebration of the Eucharist daily. ${ }^{398}$ While Mathews asserts that the congregation bore the burden of singing, ${ }^{399}$ it is clear that the continuation of this custom would have required choristers and cantors in order to lead the people in their singing.

\footnotetext{
${ }^{393}$ She initially demanded the Cathedral. Ambrose recounts his confrontation with the empress and the battle for the Portiana in his letter to his sister, Marcellina (Epistolae, $\mathrm{xx}$ ). The account is very vivid: at one point the very young Valentinian says to the bishop, "Et ego debeo habere unam basilicam (I, too, must have a church)." "Non illam (Not that one)," replies the bishop implacably. Or any other, for that matter. ${ }^{394}$ Dudden, St. Ambrose, 272.

${ }^{395}$ My emphasis.

${ }^{396}$ Dudden, St. Ambrose, 286.

${ }^{397}$ Dudden, St. Ambrose, 286

${ }^{398}$ Dudden, St. Ambrose, 442.

${ }^{399}$ Mathews, Churches of Constantinople, 124.
} 
Ambrose's clerical complement, the entourage of a prince of the Church, was already large; consisting of doorkeepers, readers, exorcists, subdeacons, deacons, archdeacons, and presbyters, ${ }^{400}$ it was a significant cohort. The addition of choristers would have necessitated additional space in the area of the presbyterium behind the sanctuary. The altar was brought forward, allowing space to accommodate more clergy. In very large churches, such as the cathedral of S. Tecla, the placement of the altar forward had the added benefit of improving the acoustical efficiency, particularly since the bishop's throne was simultaneously brought forward.

The continuation of the practice of psalmody and hymn singing which Ambrose instituted to refresh the people during their long and frightening vigil at the Portiana may have had the pragmatic purpose later of keeping a check on the restiveness of the congregation. "While they sing, there is no opportunity for that unseemly chatter by which the reading of the lessons is too often interrupted," (Ambrose, Hexameron, iii. 23). ${ }^{401} \mathrm{He}$ is also credited with a number of hymns of his own composition; Dudden notes that four hymns, including the Aeterne rerum conditor are attested by Augustine and perhaps at least three other hymns were composed by him. ${ }^{402}$

The elongation of the longitudinal axis of the church has already been noted. The service of the Mass required a series of solemn processions: the Ingressa, the procession of the Gospel, the Great Entrance of the Offertory, the procession of the offertory of the people, the procession of the clergy for communion, the procession of the people for their communion. If the emperor was in residence, he and his entourage must have required

\footnotetext{
${ }^{400}$ Dudden St. Ambrose, 129.

${ }^{401}$ Dudden, St. Ambrose, 294.

${ }^{402}$ Dudden, St. Ambrose, 296. In addition to the Aeterne rerum, Augustine notes Deus creator omnium, Iam surgit hora tertia, and Veni redemptor gentium. Cassiodorus attributes the Epiphany hymn Illuminans altissimus and the fragment Orabo mente Dominum, and possibly Splendor paternae gloriae.
} 
some ceremonial accommodation to bring him to his place. ${ }^{403}$ The expansion of the chancel area behind the altar and the development of the transept were architectural accommodations of the liturgy which facilitated the orderly movement of the clergy, choristers, and congregation during the increasingly complex service of the Mass. Like S. Tecla, none of the Ambrosian foundations had galleries or nartheces. However, they all possessed the atria that characterized the Christian basilicas of Rome.

\section{The Sacrament of Baptism}

The focus of baptism changed dramatically in the fourth century, from the mimesis of Christ's baptism of John 3:5 $5^{404}$ which emphasized the regeneration of the spirit to the Pauline interpretation in Romans $6: 3-5,{ }^{405}$ that cleansed and purified the Christian by his participation in the death and resurrection of Jesus Christ, a complex ideological and theological shift. Although liturgists dispute the reasons for the change, ${ }^{406}$ Gordon Jeanes believes that the entire dynamic of the Church had changed with the recent vision of the death and exaltation of so many martyrs, who had been baptized by blood. ${ }^{407}$ He notes that the liturgical language and development of the rite

${ }^{403}$ Mathews' sources for the role of the emperor in the Byzantine liturgy are Procopius ( $6{ }^{\text {th }}$ century), the Mystogia of Maximus ( $7^{\text {th }}$ century), and the de Ceremoniis of Emperor Constantine VII Porphyrogenitus ( $10^{\text {th }}$ century). I don't think we can extrapolate from these sources inferences of the 4th century Milanese practice, but we can infer that a Roman ceremonial (as opposed to Byzantine) was always associated with the emperor's presence.

404 "Jesus answered, 'Truly, truly, I say to you, unless one is born of water and the Spirit, he cannot enter into the kingdom of God.",

405 "Do you not know that all of us who have been baptized into Christ Jesus were baptized into his death? We were buried therefore with him by baptism into death, so that as Christ was raised from the dead by the glory of the Father, we too might walk in newness of life. For if we have been united with him in a death like his, we shall certainly be united with him in a resurrection like his."

${ }^{406}$ Gordon Jeanes, "Baptism Portrayed as Martyrdom in the Early Church," Forms of Devotion:

Conversion, Worship, Spirituality and Asceticism, ed. Everett Ferguson (NY: Garland Publishing), 1999, 159. Sebastian Brock has suggested that it was due to a desire to suppress the Jewish origins of Christianity and the hellenization of rites. Edward Ratcliff believed that the change originated in Jerusalem, with the building of the Church of the Holy Sepulchre and Cyril of Jerusalem's reinterpretation relative to the site. 407 Jeanes, "Baptism Portrayed as Martyrdom," Forms of Devotion, 159. The Church continues to accept both baptism by blood and baptism by water as valid. In an emergency, any baptized Christian can perform the rite. There is also the reification of baptism by Chrysostom $(3,16-7,163)$ : "Saint John says that, when 
reflected this dynamic: the prospective Christian now had to affirm the challenge of the Gospel and the rejection of the evil of the temporal world (Satan), just as the martyrs had affirmed it with the example of their horrific deaths.

But the age of the martyrs had passed. With the Edict of Milan, individuals who wished to commit to Christianity could do so without fear of martyrdom, and the Church faced another problem: the embarrassment of riches of new converts. ${ }^{408}$ To insure the sincerity of conversion, and the integrity of the expanding Church, the baptismal rite was invested with the mystery and sacrifice that emulated the sacrifice of the martyrs. ${ }^{409}$ Would-be converts could expect to spend at least three years (although this could be shortened) ${ }^{410}$ as catechumens, studying and reforming their lives through attendance at church, fasting, giving alms, and the practice of Christian virtue. Their sponsors were expected to monitor the quality of their lives, and they were subjected to regular 'scrutinies' by the clergy, which included exorcisms. In Milan, Ambrose took his

Christ was dead but still on the cross, the soldier came and pierced his side with a lance, and straightway there came out water and blood. The one was a symbol of baptism and the other of the mysteries... It is from both of these that the Church is sprung..." However, Annabel Wharton, "Ritual and Reconstructed Meaning: The Neonian Baptistery in Ravenna," The Art Bulletin, V. 69, 3 (Sep. 1987), 368, points out that the Church's position on baptism by blood was not unanimous. Cyprian of Carthage (d. 254) wrote, "Let not any say: 'He who receives martyrdom is baptized in his own blood and no peace from the bishop is necessary to him who is about to have the peace of his own glory..." (Cyprian, De Ecclesiae Catholicae Unitate, 4.60. 1-64.45 and 11.74. 1-20)

${ }^{408}$ Wharton, "Ritual and Reconstructed Meaning" 361 citing Palladius, Dialogus, ix who wrote that in Constantinople in 404 there were 3000 neophytes and Ambrose, de Spiritu Sancto, 1. 17 who spoke of 1000 neophytes in Milan.

${ }^{409}$ Dix, The Shape of Liturgy, 356. The question arises as to whether anyone was ever turned away. The answer is, not many - and as Dix notes, the vast majority of those who became Christians in the $4^{\text {th }}$ century remained only nominally so in their unconscious assumptions. See also Paul F. Bradshaw, "The Effects of the Coming of Christendom on Early Christian Worship," The Origins of Christendom in the West, ed. Alan Kreider (Edinburgh: T \& T Clark, 2001) 269-286, for the clergy's need to increase the "awe-fulness" quotient of the liturgy to inspire the half-converted, and Testa, "Christianization and Conversion in Northern Italy," on Bishop Maximus of Turin's (380-465) effort to use the legal process of civil authority to require the padrones to force the conversion of their rusticas.

${ }^{410}$ Klauser, A Short History of the Western Liturgy, 13, and Kreider, "Changing Patterns of Conversion in the West," The Origins of Christendom in the West, 10: The Canons of Elvira in Spain extended this period to five years. 
responsibilities for the instruction and baptism of his catechumen-elects very seriously and personally supervised their spiritual education and reception in the congregation.

In the Milanese rite, catechumens who wished to receive baptism submitted their names to the bishop at the beginning of Lent, ${ }^{411}$ and the eight-week (Lent is six weeks under the Roman canon) period was spent in confession, mortification, fasting and instruction as to the responsibilities of a Christian. ${ }^{412}$ Baptism was administered at the Vigil of Holy Saturday ${ }^{413}$ by immersion at the bishop's hands, in the baptistery, with the sponsors (godparents) and clergy present. Following the rite, the entire group processed back to the church and the newly baptized were initiated into the mysteries of the Eucharist for the first time, with the celebration of the great Easter Mass of the Resurrection, ${ }^{414}$ and a special communion ceremony was provided for the new Christians. However, in the usage of the Milanese canon, they did not participate in the Offertory. ${ }^{415}$ That privilege did not come until the Octave of Easter (the following Sunday). During this week between baptism and their first participation as fully initiated members of the congregation, special masses were offered for them and Ambrose himself continued their education, personally ministering to them concerning the nature of the sacraments and the Lord's Prayer, and the Apostles' Creed. ${ }^{416}$

\footnotetext{
${ }^{411}$ Dudden St. Ambrose, 336.

${ }^{412}$ Dudden St. Ambrose, 337.

${ }^{413}$ As noted above, it could also be administered at Epiphany, after the Eastern practice, which celebrated Epiphany as the Baptism of Christ.

${ }^{414}$ Dudden St. Ambrose, 342.

${ }^{415}$ Ambrose, Expos. ps, cxvii, 'Licet in baptismate plena sit statim purgation, tamen quiz ablutionis ipsius sacrificiique rationem baptizatus debet cognorscere, non offert sacrificium nisi octavuum ingrediatur diem, ut informatus agnitione sacramentorum coelestium non quasi rudis, sed quasi rationis capax, tunc demum auum munus altaribus sacris offerat, cum coeperit esse instrurcior, ne offerentis inscitia contaminet oblationis mysterium.' Ambrose's concern for the neophytes' instruction in the sacraments, which took place during the Octave of Easter, may have been the rationale for refusing to allow them to participate in the Offertory. The six treatises in De sacramentis began on Easter Tuesday and ended on the following Sunday.

${ }^{416}$ Dudden. St. Ambrose, 342
} 
Liturgically, the rite of baptism was imbued with awe and holiness, a cleansing of the body as the surrogate of the soul, and the Ambrosian baptism, from what we can learn from De mysteriis, closely followed the Apostolic Tradition and the liturgy developed by Cyril of Jerusalem. ${ }^{417}$ The bishop began the ceremony by touching the candidate's ears and nostrils, repeating Christ's words over the deaf and dumb man, "Effetha, quod est adaperire." ${ }^{, 418}$ Although Ambrose doesn't say what unguent was used for this anointing, E. J. Yarnold believes that this was a prudish reticence on Ambrose's part, since there is every indication that, like Christ, the bishop used spittle. ${ }^{419}$

In the Apostolic Tradition, the candidates were specifically enjoined to "put off their clothes" and "Let them stand in the water naked." ${ }^{, 20}$ St. John Chrysostom required the priests to strip the neophytes completely for their anointing and immersion. ${ }^{421}$ But the Didascalia Apostolorum required that deaconesses attend to the anointing of women; ${ }^{422}$ Ambrose makes no mention of deaconesses during baptism, and although he does treat the subject of nakedness, ${ }^{423}$ it is not in connection with baptism. This silence of Ambrose on the subject of the stripping of the candidates and the fact that the Milanese baptisteries were not designed with screened areas to protect privacy ${ }^{424}$ have led Annabel

${ }^{417}$ E. J.Yarnold, "The Ceremonies of Initiation in the De Sacramentis and De Mysteriis of S. Ambrose," Studia Patrista : Papers presented to the Second International Conference on Patristic Studies Held at Christ Church, Oxford, Vol. 10, eds. Kurt Aland, F. L. Cross, Elizabeth A. Livingston (Berlin: Akademie Verlag, 1970), 455.

${ }^{418}$ Mark 7:34, "Then, looking up to heaven he sighed; and he said to him, "Ephphatha," that is, "Be opened."

${ }^{419}$ Yarnold, "The Ceremonies of Initiation of S. Ambrose," 455. The twelfth and thirteenth century Ambrosian liturgical books enjoin the priest to touch the ears and nostrils with spittle. Yarnold speculates that the mouth was not touched (as Christ had done) for reasons of propriety.

${ }^{420}$ Hippolytus, The Apostolic Tradition, 21.3, 5, 11 .

${ }^{421}$ Wharton, "Ritual and Reconstructed Meaning," 362.

${ }^{422}$ Wharton, "Ritual and Reconstructed Meaning, 362.

${ }^{423}$ Ambrose, Epistolae, 28.

${ }^{424}$ Wharton, "Ritual and Reconstructed Meaning," 362 gives examples of baptisteries in the East and North Africa (baptisteries of Cyprus, the baptismal complex of Kourion) which made provision for the modesty of the women candidates. 
Wharton to propose that in Milan, the neophytes wore shifts to protect their modesty. ${ }^{425}$ This inference requires a significant leap, which may not be valid. Ambrose so closely followed Cyril of Jerusalem's liturgical practice in so many instances that I doubt that he would have diverged so completely from an essential tenet of the process. Stylistically, De mysteriis is written without reference to either men or women, addressed only to the generic candidate. The addition of shifts would, in fact, have been far more than a "modest departure from tradition" ${ }^{426}$ for Ambrose. There is also the issue of Ambrose's romanitas, which appears to have dictated much of his public persona. It is possible that he does not mention the nakedness of the candidates because he viewed nakedness without embarrassment, as natural and normal within the gymnasium and the arena, a metaphor that he does employ (see below). ${ }^{427}$

After being stripped completely, the candidates were anointed from head to toe with oil by the presbyters and deacons. In this anointing, which was meant to confer strength to the candidate, the candidate was treated like an athlete preparing for a competition. Paul had defined this theme in 2 Timothy 4: 7-8: "I have fought the good fight, I have finished the race, I have kept the faith. From now on there is reserved for me the crown of righteousness, which the Lord, the righteous judge, will give me on that day." Ambrose, too, reiterated this theme in De sacramentis: "We arrived at the baptistery...you were rubbed with oil like an athelete, Christ's athlete, as though in

\footnotetext{
${ }^{425}$ Wharton, "Ritual and Reconstructed Meaning," 363.

${ }^{426}$ Wharton, "Ritual and Reconstructed Meaning," 363.

${ }^{427}$ By the same token, that very romanitas should have guaranteed the protection of the women, who, as Roman women, were required to maintain a standard of modest decorum, and who did not participate in the gymnasium. Nevertheless, Ambrose so closely followed the lead of Cyril of Jerusalem liturgically that I strongly doubt that he would have varied on this point, which had both symbolic and theological implications.
} 
preparation for an earthly wrestling-match, and you agreed to take on your opponent.",428

Following this anointing (the second of three) the candidate turned and faced west to make his renunciation of the devil. Cyril of Jerusalem's instruction for the rite indicated that this renunciation was elaborate, but Ambrose is less forthcoming. In De sacramentis, ${ }^{429}$ he described a twofold renunciation in the form of an interrogatory, conducted by a presbyter: "Do you renounce the devil and his pomp and works? Do you renounce the world and its pleasures?" 430 To which the candidate would answer, "I renounce." The interrogatory form of establishing a contract was a Roman practice; ${ }^{431}$ Ambrose followed the rite of renunciation with an admonition to remember the bond to which they were committed, a bond which was witnessed and recorded by angels in heaven. ${ }^{432}$ As a gesture of contempt for the devil, the presbyter then spat in the face of the candidate; ${ }^{433}$ from De mysteriis we learn that the renunciation was followed by a turn to the east with the words of adhesion to Christ. ${ }^{434}$

After this anointing, the water in the piscina (a pool which was the font) was blessed with oil and the sign of the cross. Ambrose alludes to the rod of Moses that

\footnotetext{
${ }^{428}$ Jeanes, "Baptism Portrayed as Martyrdom," Forms of Devotion, 165.

${ }^{429}$ Dudden, St. Ambrose, 338: Ambrose, De sacramentis, i. 5.

${ }^{430}$ This interrogatory is substantially the same in the current Roman canon, and Catholic Christians renew their baptismal vows yearly during the celebration of Easter. However, the devil has become an oldfashioned concept and an alternate form is provided that seems appropriate to our time: "Do you renounce the glamour of evil?" Evil, of course, is an old-fashioned concept that never seems to go out of fashion. It is a matter of pastoral preference which form is used.

${ }^{431}$ Klauser, A Short History of the Western Liturgy, 13.

${ }^{432}$ Dudden, St. Ambrose, 338: Ambrose, De sacramentis, i. 5: "Be mindful of thy words, and never let the contents of thy bond pass from thy memory," and Jeanes, "Baptism Portrayed as Martyrdom," Forms of Devotion, 169-170: Ambrose, De sacramentis 1, ii.6: "Your guarantee is binding, not on earth, but in heaven." and Ambrose, De Mysteriis, 5: "Your words are kept not in the tomb of the dead but in the book of the living."

${ }^{433}$ Dudden, St. Ambrose, 338. This practice was continued at least into the $16^{\text {th }}$ century. In arranging for the baptism of James VI of Scotland (James I of England), 1566, the Diurnal of Occurrents of Scotland noted that the queen (Mary Queen of Scots), 'did inhibit' the use of spittle, saying that she was not going to have a 'pocky priest' spitting in her baby's mouth. See Antonia Fraser, Mary Queen of Scots (NY: Dell Publishing), 1993, 280).

${ }^{434}$ Ambrose, De mysteriis, 7: “Ad orientum converteris: qui enim renuntiat diabolo ad Christum convertitur."
} 
sweetened the bitter water of Mara, so it is possible that he used his staff with its cruciform headpiece to bless the water. ${ }^{435}$ The naked candidates were then triply immersed in the font: with each immersion they were again interrogated and affirmed their belief in the three Persons of the Trinity. Following their immersion, they were again anointed, Ambrose pouring chrism on their heads. This anointing signified regeneration (te unguet in vitam aeternam: De sacramentis 2. 24, 3.1), and the conferring of a priestly royalty (in regnum dei et sacerdotium: De mysteriis 29-30); with this anointing the sacrament of Confirmation was added.

The bishop now knelt to wash their feet, mimicking Christ's humility and sanctifying the elect. Ambrose notes that while baptism washed away all sin, this additional sanctification was made to symbolically cleanse the point where Adam was poisoned by the serpent, the contamination of mankind with Original Sin. ${ }^{436}$ To reinforce this, the Milanese rite added something to the pedilavium: the bishop kisses the foot of the candidate, and placed it on his own head three times. ${ }^{437}$

As already noted, the use of the pedilavium placed the Milanese Church strongly at odds with the Roman Church, which used it only in services on Holy (Maundy) Thursday as an example of Christ's humility and acceptance of the will of God, but never attached any sacramental value to it. ${ }^{438}$ However, the Eastern Church's use of it as part of the baptismal rite speaks to the vexing question of whether the Apostles of Christ were baptized. There is no indication in the Gospels that any of the Apostles were baptized in the manner of Christ's baptism by John the Baptist, and the Gospel of John says very

\footnotetext{
435 Yarnold, "The Ceremonies of Initiation of S.Ambrose," 459: Ambrose, De sacramentis 2.13.

${ }^{436}$ Dudden, St. Ambrose, 341: Ambrose, De sacramentis, iii. 7.

${ }^{437}$ Ernst H. Kantorowicz, "The Baptism of the Apostles," Dumbarton Oaks Papers, V. 9 and 10, 1956, 231.

${ }^{438}$ Kantorowicz, "Baptism of the Apostles," 223.
} 
clearly, (John 4: 1-2) "Jesus himself did not baptize, but his disciples did." "439 The problem that so disturbed the early Church was the dominical proscription of John 3:5: "Except a man be born of water and of the Spirit, he cannot enter into the kingdom of God." It was unthinkable that Christ's own disciples should not share in Christ's redemptive promise, ergo, some form of baptism must have taken place. From the Johnnine account ${ }^{440}$ of the Last Supper, the communion of the disciples is omitted. Instead, we learn that Christ washed the feet of the disciples. When Peter protested, "Thou shalt never wash my feet," Jesus answered him: "If I wash thee not, thou hast no part of me." ${ }^{441}$ In the Eastern Church, Christ's insistence on washing each of the disciples' feet ${ }^{442}$ represented his baptism of the Apostles, echoing an exigetical typology among the patristic writers that associated other events with the water of baptism. ${ }^{443}$

There is no doubt that Ambrose viewed the pedilavium as sacramental, if not quite a sacrament. His continuation of his defense of the Milanese practice ${ }^{444}$ is strongly worded:

WE follow the Apostle Peter himself. WE cling to his devotion. What says the Roman Church now? For to us the Apostle Peter himself is the author of our assertion, he who was a priest of the Roman Church. Peter himself said: "Lord, not my feet only, but also my hands and my head." Notice the faith. What first he objected to, was a matter of his humility; what afterwards he offered, was a matter of his devotion and faith.

Ambrose, De sacramentis, iii. 1.6

\footnotetext{
${ }^{439}$ Kantorowicz, "Baptism of the Apostles,"208.

${ }^{440}$ John's Gospel is the only account of Christ washing the feet of the Twelve; it does not appear in Matthew, Mark or Luke.

${ }^{441}$ John 13: 6, 8 .

${ }^{442}$ Peter was not the first of the disciples to be laved, but he was the only one to protest. The action of the pedilavium takes place prior to Christ's giving the sop of bread to Judas Iscariot (identifying Judas as his betrayer), so presumably Judas' feet were bathed as well.

${ }^{443}$ Kantorowicz, "The Baptism of the Apostles," 211, e.g. Hippolytus associated the bath of Susanna as a baptism, Aphraates speaks of Israel baptized in the Red Sea, Origen links Abraham's laving of the angels before feeding them to baptism before the reception of the Eucharist.

${ }^{444}$ See above, page 99.
} 
Conceptually, Ambrose focused on the positive aspects of Peter's dialogue with Christ You will have no part of me unless I wash your feet and Peter's acceptance: then, wash me completely, my head and my hands as well. Ambrose's own exegesis linked the reluctance of Peter to be laved to John the Baptist's reluctance to baptize Christ, ${ }^{445}$ establishing the correlation between the baptism of Epiphany and the laving of the disciples' feet.

Finally, the newly-baptized Christians were clothed in white garments, blessed with the laying on of hands and kissed. They were now ready to process back to the church where they would be introduced to the mystery of the Eucharist for the first time. During another week of instruction in the elements of the canon and the Lord's Prayer, special communion ceremonies were arranged for them. In addition to the bread and wine of the Eucharist, they were also given a chalice with milk and honey to drink, which symbolized the nurturing that they received in partaking of the Eucharist, and the sweetness of Christian scripture. ${ }^{446}$

Although infant baptism continued to be encouraged, ${ }^{447}$ most catechumens were adults seeking membership in the Church. The architectural requirements for the administration of the sacrament and the accommodation of catechumens, their sponsors,

\footnotetext{
${ }^{445}$ Matthew 3: 13-15: "The Jesus appeared: he came from Galilee to the Jordan to be baptized by John. John tried to dissuade him, "It is I who need baptism from you," he said, "and yet you come to me!" But Jesus replied, "Leave it like this for the time being; it is fitting that we should, in this way, do all that righteousness demands." At this, John gave in to him."

${ }^{446}$ Yarnold, "The Ceremonies of Initiation of S. Ambrose," 463.

${ }^{447}$ Klauser, A Short History of the Western Liturgy, 14. Klauser notes that when Hippolytus wrote the Apostolic Tradition (ท́ A his account of Ambrose's death and funeral, Paulinus writes that during the Easter vigil, children returning from the font saw the bishop sitting in his cathedra, others saw him walking toward them. Although the children pointed him out to their parents, these latter did not see him (Paulinus, Vita ambrosii, 48). Ambrose died in the early morning hours of Easter Saturday, the day of the vigil.
} 


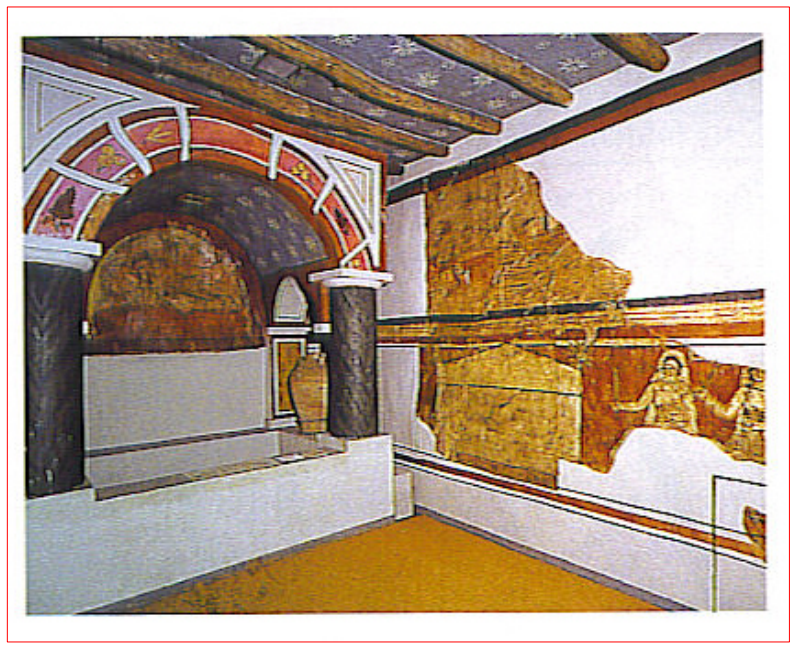

Figure 36: Duro Europos, Syria: Christian baptistery (c. 211) (Reconstruction) and their families had long since exceeded the facilities afforded by the interior baptistery (such as seen in the double cathedral of Aquileia, Figure 16), and the construction of separate baptisteries appeared almost simultaneously with the construction of the first great

$$
\text { Constantinian basilicas. }{ }^{448} \text { The }
$$

Didache had required that "You shall

baptize in living water" (Didache, 7.1.3.), ${ }^{449}$ a practice which hearkened back to Jewish purification rituals and the construction of the miqvah (ritual bath) which also required a fresh water source. ${ }^{450}$ Architecturally, the one sure requirement for a baptistery was the font, or piscina; initially, this was a rectangular basin, like the mikvah, large enough for a candidate to step into and sufficiently deep to permit immersion. Later, the font was circular or polygonal.

Krautheimer notes that early baptisteries were never round or polygonal in the third and early fourth centuries: ${ }^{451}$ this development occurred in the latter half of the fourth century. He suggests that the separate, round baptistery was influenced by two architectural traditions: collaterally and anciently, the bath building, and, more

\footnotetext{
${ }^{448}$ Krautheimer, Early Christian and Byzantine Architecture, 90.

${ }^{449}$ Klauser, A Short History of the Western Liturgy, 12.

${ }^{450}$ See Martin Goodman, State and Society in Roman Galilee A.D. 132-212, (London: Vallentine Mitchell), 2000 , on the demographics of second century Sepphoris and the inferred presence of priestly families as extrapolated from the number of miqveh excavated.

${ }^{451}$ Richard Krautheimer, "Introduction to an 'Iconography of Medieval Architecture,"” Journal of the Warburg and Courtauld Institutes, 5, 1942, 22. Examples include the baptistery at Duro Europas (231), the first baptisteries of the Lateran, Aquileia, Nesactium and Salona (early $4^{\text {th }}$ century).
} 


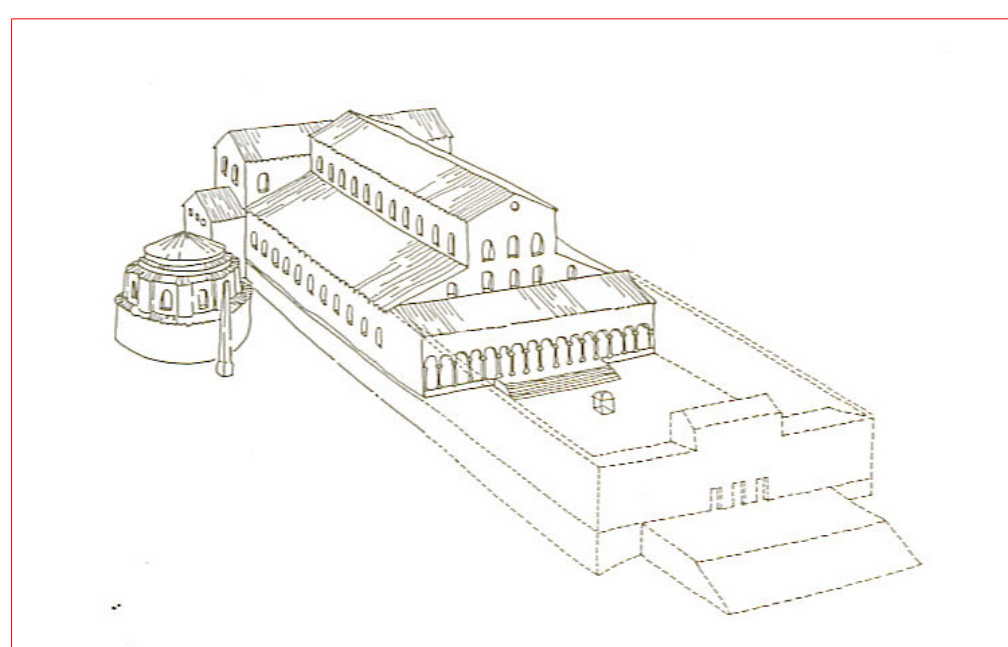

Figure 37: Rome: Reconstruction of Old St. Peter's, c. 400, showing the separate baptistery

While both structures were connected architecturally in their construction as round or immediately, the imperial mausoleum, ${ }^{452}$ and there is some evidence that early baptisteries were built on or near ancient bath-buildings, to fulfill the requirement of the Didache with an existing water source. $^{453}$ round-like buildings, only the Roman mausolea of the third and fourth centuries exhibited the architectural combination of a "vaulted centre-room with either an inner or a closed and relatively low, outer ambulatory" ${ }^{\prime 44}$ that characterized the structural development of the late fourth century early Christian baptistery. Symbolically, both building types contributed to the architectural symbolism of the baptistery: the bathing away of sin and the participation in the death and resurrection of Jesus Christ and the martyrdom of the early Christians.

\section{The Cult of the Saints}

The period of the fourth and fifth centuries, following the end of the age of martyrs, witnessed an accelerating growth in the cult of the saints as an extension of the

\footnotetext{
${ }^{452}$ Richard Krautheimer, "Introduction to an 'Iconography of Medieval Architecture,"”21, 26.

${ }^{453}$ Nicholas Temple, "Conversion and Political Expedience: Imperial Themes in the Early Christian Baptistery," Anales del Instituto de Investigaciones Estéticas, XXIV, no. 80, 2002, 7. Examples include the Lateran Baptistery in Rome and the Neonian (Orthodox) Baptistery in Ravenna. However, one must consider that this aspect must most likely be incidental. Early $4^{\text {th }}$ century churches were initially constructed outside the city walls, whereas Romans baths were generally located more centrally. For those structures of the late $4^{\text {th }}$ century, such as the Milanese baptistery attached to S. Tecla, and the $5^{\text {th }}$ century Neonian Baptistery of Ravenna, it is far more likely that the buildings tapped into the hydraulics of nearby urban baths, or had their own hydraulic systems built ex novo.

${ }^{454}$ Krautheimer, "Introduction to an 'Iconography of Medieval Architecture,"” 25.
} 
original practice of the veneration of the holy sites of martyrdom of the Apostles and the first martyrs. It could be argued that Constantine's mother, St. Helena, ${ }^{455}$ whose identification of the holy places of Christ's Passion and the discovery of the relics of the True Cross,${ }^{456}$ inspired a frenzy of church-building in the East, and the subsequent phenomenon of pilgrimage gave impetus to what had been a quiet practice of reverence. But within local areas, there appears to have been some spontaneous veneration of the local saints from a very early period; ${ }^{457}$ the pagan practices of venerating the lives and deaths of mythical or real heroes were older than recorded history and gave impetus to the early cult of the saints. ${ }^{458}$

In the early Church, the first saints were, of course, the martyrs, and that veneration began very early. In a letter to the 'church of God sojourning at Philomelium,' the Christians of Smyrna wrote of their disposition and veneration of the remains of St. Polycarp (d. 155):

And so we on our part afterwards took up his bones, more valuable than precious stones and purer than wrought gold, and laid them in a fitting place. And when we assemble there accordingly to our power in gladness and joy the Lord will permit us to celebrate the birthday of his martyrdom, both in memory of those who have already contended, and for the training and preparation of such as shall hereafter do the same. ${ }^{459}$

Already in this passage, we can begin to discern some of the aspects that characterized the cult of the saints: the value of the body and its reverence, the creation of a "fitting

\footnotetext{
${ }^{455}$ St. Helena, patron saint of archeologists, is revered in both the Eastern and the Western Church.

${ }^{456}$ John Crook, The Architectural Setting of the Cult of Saints in the Early Christian West, c. 300-1200 (Oxford: Clarendon Press, 2000, 27: Crook notes that Eusebius did not mention the discovery of the True Cross, nor did he mention Calvary. Gibbon, pointing to the silence of Eusebius and the Bordeaux Pilgrim, notes that it is that "which satisfies those who think, perplexes those who believe (Decline and Fall of the Roman Empire, cap. 23). For Ambrose's account of the Invention of the True Cross, see Oratio de obitu Theodosii, 43.

${ }^{457}$ Humphries, Communities of the Blessed, 54.

${ }^{458}$ Krautheimer, Early Christian and Byzantine Architecture, 32.

${ }^{459}$ John Crook, The Architectural Setting of the Cult of Saints, 10, citing the preservation of this letter in Eusebius of Caesarea, Hist. Eccl., iv. 15.
} 
place" for the burial which would accommodate the commemoration of the faithful on the anniversary of the saint's martyrdom, ${ }^{460}$ and the inspiration that the faithful drew from the example of the saint's life and death in Christ.

Later saints who did not die as martyrs but were witnesses by the quality of their lives were recognized as saint "Confessors." Such were St. Zeno of Verona, St. Martin of Tours, and many of the bishop saints of the early Church. During the fourth and fifth centuries, spontaneous veneration by the people of the holiness of an individual conferred sainthood, and the local bishop could institutionalize the practice by designating the saint as a Confessor. Augustine has given a very clear picture of the process of recognizing and venerating the Confessors. ${ }^{461}$ However, the papacy's program of primacy in the West eventually interfered with this prerogative of the bishops, and Pope Alexander III (115981) issued a decretal that prohibited the veneration of saints that had not been recognized by the Roman see. This was expanded in 1634 when Pope Urban VII issued a bull reserving the beatification and canonization of saints to the papacy exclusively. This process is now a lengthy one: administered by the "Devil's Advocate," a papal investigator, the possible sainthood of an individual involves a meticulous probe of the holiness of a person's life, as well as the witness testimony of the miracles associated with that person, either during his lifetime or as an intercessor. ${ }^{462}$

We have seen how the venerability of a see that could trace its foundation to the Apostles enhanced and extended the influence of that see. Rome, of course, was the site

\footnotetext{
${ }^{460}$ Early Christian sources frequently refer to the date of martyrdom as the "birthday" of the saint.

${ }^{461}$ Catholic Encyclopedia Online, s.v. "Beatification and Canonization," http://www.newadvent.org/cathen/02364b.htm: Augustine, Quaest. in Heptateuch., II, n. 94; Contra Faustum, 20, xxi.) (accessed March 31, 2008).

${ }^{462}$ Catholic Encyclopedia Online, s.v. "Beatification and Canonization," http://www.newadvent.org/cathen/02364b.htm: (accessed March 31, 2008).
} 
of the martyrdoms of the two great Apostles, Peter and Paul, second only to Christ himself, and it was during the episcopate of Pope St. Damasus that the cult of those saints was used to extend the hegemony of the Roman see. ${ }^{463}$ In effect, this process of promoting the cult of the saints became the Christian version of the ancient Roman practice of patronage, to the reciprocal benefit of the patrone see and the suffragan see, which had explicitly aristocratic and urban formation. ${ }^{464}$

The distribution of relics, the removal of bodies from their original burial location (translation), and particularly the scattering of body parts were singular departures from both ancient Judaic and Roman practice. Judaism required that persons who handled the bodies of the dead or who had entered a tomb be ritually purified, ${ }^{465}$ while the Roman prohibition of uiolatio sepulchri continued to be enforced legally as late as 386, when Theodosius reaffirmed the decrees of his predecessors against the removal or distribution of relics (permitting, however, the erection of a martyrial structure). ${ }^{466}$

The translation and fragmentation of bodies spoke to the belief that the power of a saint was vested in the body, and only secondarily in the place of burial, and there was a gradual acceptance that the bodies could be moved to a location that was more convenient for the veneration of the faithful. Fragmentation, of course, allowed the power of the saint's body to be shared in multiple locations. In the East, translation of relics began in Constantinople in the fourth century: the body of St. Babylas was translated to a church in Daphne (351-4), and Constantius transferred the bodies of Saints

\footnotetext{
${ }^{463}$ Humphries, Communities of the Blessed, 54.

${ }^{464}$ Peter Brown, The Cult of the Saints: Its Rise and Function in Latin Christianity (Chicago: University of Chicago Press), 1981, 124.

${ }^{465}$ Crook, Architectural Setting of the Cult of Saints, 12.

${ }^{466}$ Codex Theodosiani, ix. 17: "No person shall transfer a buried body to another place. No person shall sell the relics of a martyr; no person shall traffic in them. But if any one of the saints has been buried in any place whatever, persons shall have it in their power to add whatever building they may wish in veneration of such a place, and such building must be called a martyrium."
} 
Luke, Andrew, and Timothy to the Aposteleion in 356-7. ${ }^{467}$ Jerome described the translation of the prophet Samuel to Constantinople in $408 .^{468}$

In the West, however, the popes found it convenient to oppose fragmentation as a strategic option, allowing them to control the development of cults. In 519 Pope Hormisdas refused the Emperor Justinian when he asked for pieces of the bodies of St. Peter and St. Paul for the dedication of a church in Constantinople, and in 594 Pope St. Gregory I likewise refused the Empress Constantina, who requested the head or another body part of St. Paul for a similar purpose. ${ }^{469}$ Writing to the empress, Gregory professed himself shocked:

For in the Roman and all the western parts it is unendurable and sacrilegious for anyone by any chance to desire to touch the bodies of saints: and if one should presume to do this, it is certain that this temerity will by no means remain unpunished. For this reason we greatly wonder at the custom of the Greeks, who say that they take up the bones of saints; and we scarcely believe it. ${ }^{470}$

However, Gregory's incredulity is not entirely the shock of a naïf. John Crook has noted that the context of the letters indicates that Gregory's predecessor, Pelagius II, was not so overly-scrupulous, and that Gregory's own underlying motivation may have been less the enforcement of the imperial prohibition than a desire to control the cult of relics among the churches of Rome. ${ }^{471}$

Both Justinian and Constantina were fobbed off with contact relics, brandea, which points to another aspect in the logical development of the cult of the saints. If the power (virtus) of the saint was vested in the body of the saint (the primary relic), then that

\footnotetext{
${ }^{467}$ Crook, The Architectural Setting of the Cult of the Saints, 19.

468 Jerome, Contra Vigilantium, 5: Jerome questioned rhetorically whether the translation of the Apostles' relics to Constantinople was sacrilegious.

${ }^{469}$ Crook, The Architectural Setting of the Cult of the Saints, 23.

${ }^{470}$ Gregory I, Epistolae, iv. 30.

${ }^{471}$ Crook, The Architectural Setting of the Cult of the Saints, 23-24.
} 
power was also vested in anything that touched that body (the secondary relics).

Concerning the objects that had been in the Tomb of Christ, Gregory of Tours wrote,

"Faith believes that anything that has been touched by the sacred Body is holy.", ${ }^{472}$ As

the splinters of the wood of the Cross were distributed far and wide, St. John Damascene,

writing in the eighth century, wrote to clarify the concept:

The wood of the Cross...is to be venerated as something more holy by having touched his sacred body and blood, [and so are] the nails, the lance, the clothes, and his sacred 'tabernacles,' that is to say the Manger, the Cave, saving Golgotha, the life-giving Tomb, Sion....and such like.

St John Damascene, De fide orthodoxa, iv. 14

The concept was well-attested and validated by the New Testament; all four of the synoptic Gospels give the account of the woman who was afflicted by an issue of blood who was cured by simply touching the hem of Christ's garment:

[a certain woman] came in the press behind, and touched his garment. For she said, If I may touch but his clothes, I shall be whole. And straightway the fountain of her blood was dried up; and she felt in her body that she was healed of that plague. And Jesus, immediately knowing in himself that virtue $e^{473}$ had gone out of him, turned him about in the press, and said, Who touched my clothes?

Mark 5: 27-30.

This power was inherited by the Apostles: In Jerusalem, Peter's shadow healed (Acts 5:14-15), and cloth that had been in contact with Paul's body not only healed the afflicted but also drove out evil spirits:

\footnotetext{
${ }^{472}$ Crook, The Architectural Setting of the Cult of Saints, 25: Gregory of Tours, Liber in Gloria Martyrum, I, 492, "Fides retineat, omne quod sacrosanctum corpus attigit esse sacratum."

${ }^{473}$ My emphasis: the concept of a saint's virtus may be found here.
} 
And God wrought special miracles by the hands of Paul: So that from his body were brought unto the sick handkerchiefs or aprons, and the diseases departed from them, and the evil spirits went of them.

$$
\text { Acts 19: } 11-12^{474}
$$

At St. Peter's basilica, the process of developing contact relics, ${ }^{475}$ was described by Gregory of Tours based upon the description of the deacon Aigulf:

For if someone wants to take away a blessed relic, he leaves a little cloth, previously weighed on a balance, inside [the shrine]. Then, keeping vigil and fasting, he earnestly prays that the apostolic virtue may assist his piety. Wondrous to relate! If the faith of the man is strong, when the cloth is raised from the tomb it is so soaked by divine power that it weighs much more than it previously did, and then the man who raises it knows that by its grace he has received what he requested. ${ }^{476}$

There is no doubt that Ambrose, inspired by Pope Damasus, played a pivotal role in establishing the cult of the saints in northern Italy. In referring to Gervasius and Protasius, Ambrose says that the Church of Milan was "barren of martyrs" "477 but that these saints would become "the mother of many children." 478 In addition to receiving relics of the Apostles from Damasus, and discovering the relics of St. Gervasius and St. Protasius, Ambrose also uncovered the relics of St. Nazarius and St. Celsus. From Bologna he imported the relics of St. Vitalis, and it was in Bologna that he discovered the relics of St. Agricola. ${ }^{479}$ Humphries notes that the only real evidence of the saints' veneration in Milan prior to the incumbency of Ambrose was associated with the cellae

\footnotetext{
${ }^{474}$ The Roman Church was extremely protective of the bodies of Peter and Paul and refused to allow fragmentation of the Great Apostles. All of the relics associated with them are contact relics.

${ }^{475}$ Crook, The Architectural Setting of the Cult of the Saints, 26, called sanctuaria by Gregory the Great

${ }^{476}$ Crook, The Architectural Setting of the Cult of the Saints, 26: Gregory of Tours, Liber in Gloria Martyrum, 27.

${ }^{477}$ Ambrose, Epistolae, xxii. 22, 7.

${ }^{478}$ Ambrose, Epistolae, xxii. 7.

${ }^{479}$ Humphries, Communities of the Blessed, 55.
} 
memoriae of Sts. Nabor and Felix. ${ }^{480}$ And, as Ambrose distributed relics to other sees, ${ }^{481}$ he was imitated by other bishops. ${ }^{482}$

A cynical construction of the political effects of the cult of the saints is both facile and simplistic, a small part of a larger picture that had significant consequences. But it ignores the genuine well-spring of veneration of the saints that was generated among the faithful. As we have seen, the relatively late development of the northern Italian churches was concurrent with the Late Antique disintegration of the Roman Empire, a fact which played into the need of the faithful to rely on the protection of the supernatural. People found a familiar comfort in the veneration of a favorite saint, just as in another age they had found comfort in the protection afforded by their household gods. The saint, who in many instances was an individual of relatively recent memory, was the accessible intercessor to a remote deity, a real person who could inspire the faint-hearted, give strength to the weak, sick and maimed, and provide companionship and reassurance in the last great passage between life and death. The pilgrimages induced by the presence of the relics of a saint or martyr which brought material benefit to a see is only one facet in understanding the extreme popularity of the cult of the saints at this period in the fourth century, and its promotion by Ambrose and the hierarchy of bishops. Whatever the interpretation of the miracle of Saints Gervasius and Protasius, there is little doubt that Ambrose fervently believed in the protection and patronage of saints and in the translation of relics. ${ }^{483}$

\footnotetext{
${ }^{480}$ Humphries, Communities of the Blessed, 55.

${ }^{481}$ As has been noted, Roman law prohibited the dismemberment of bodies. Unless the body was found in the entirety of its skeleton, which was then preserved, the early distribution of relics most frequently took the form of brandea, pieces of clothing or articles that were associated intimately with the saint. See below Chapter V, "The Ambrosian Foundations," on the relics dedicated in the Basilica Apostolorum.

${ }^{482}$ Humphries, Communities of the Blessed, 55. Notably Chromatius of Aquileia.

${ }^{483}$ Dudden, St. Ambrose, p. 308.
} 
Liturgically, the saints were included in the reading of the litany of the saints in the formulae of the Eucharistic prayer, and in the dedication of feast days which commemorated their birth or death or an important miracle. Additionally, the Church provided for the extra-liturgical use of private devotional forms that were associated with the saints: the devotion of the Rosary is an example of the private devotion that developed during the medieval period that was associated with the sainthood and cult of Mary, the Virgin Mother of God. ${ }^{484}$

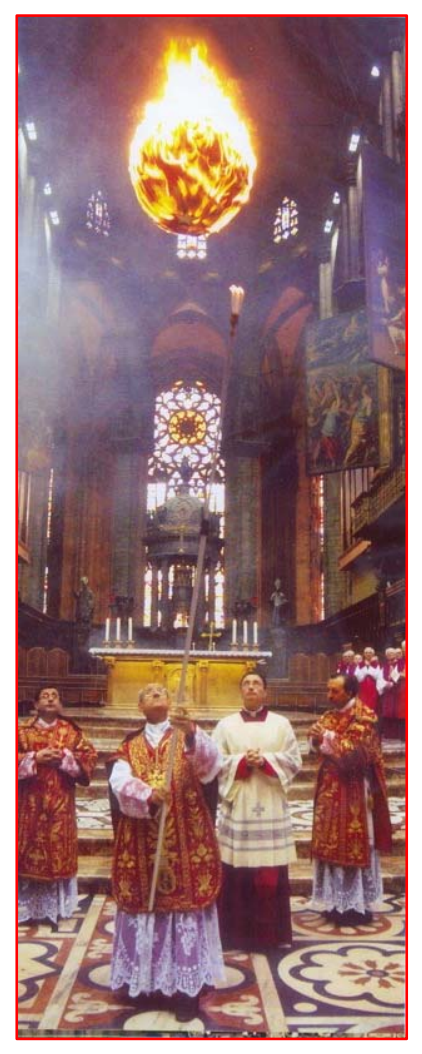

King mentions a peculiar (and potentially dangerous) ceremony of great antiquity still practiced in the Milanese cathedral which he believes refers to the burning of torches before the graves of the martyrs in the catacombs. ${ }^{485}$ This is the burning of the Faro, a large bundle of cotton which is hung in the cathedral and lit for the feasts of martyrs. King notes that the earliest mention of this practice occurs in the seventh century, but it was in common practice in northern Italy and Gaul for churches using the Ambrosian rite, which is the only rite that uses it. The Cologne missal of 1525 placed the enactment of this ceremony in the Easter Vigil,

Figure 38: Milan, The after the re-affirmation of the baptismal vows.

Lighting of the Faro

\footnotetext{
${ }^{484}$ Mary was recognized as the Theotokos ("God Bearer") at the Council of Ephesus in 431, an important point in the Christological debate, since it affirmed the divine nature of Jesus Christ. The council additionally affirmed that the Nicene Creed of 381 was essential and complete. Her cult was recognized from the late fourth century, but her devotion expanded greatly during the $11^{\text {th }}$ and $12^{\text {th }}$ centuries. See Norman F. Cantor, The Civilization of the Middle Ages, (NY: Harper Collins), 1993, 339. St. Mary, incidentally, is the patron saint of the United States.

${ }^{485}$ King, Liturgy of the Primatial Sees, 289.
} 
Almost all of the architectural accommodation associated with the cult of the saints served roughly two purposes: to reverence or commemorate the body of the saint or saint's relics in a fitting manner, and to allow accessibility to the relics for the faithful. As the cult of the saints developed in the fourth and fifth centuries, the architectural setting could be found in separate chapels dedicated as martyria; in the event that the entire church was a martyrium, a crypt was included. Within a church, niches (often the

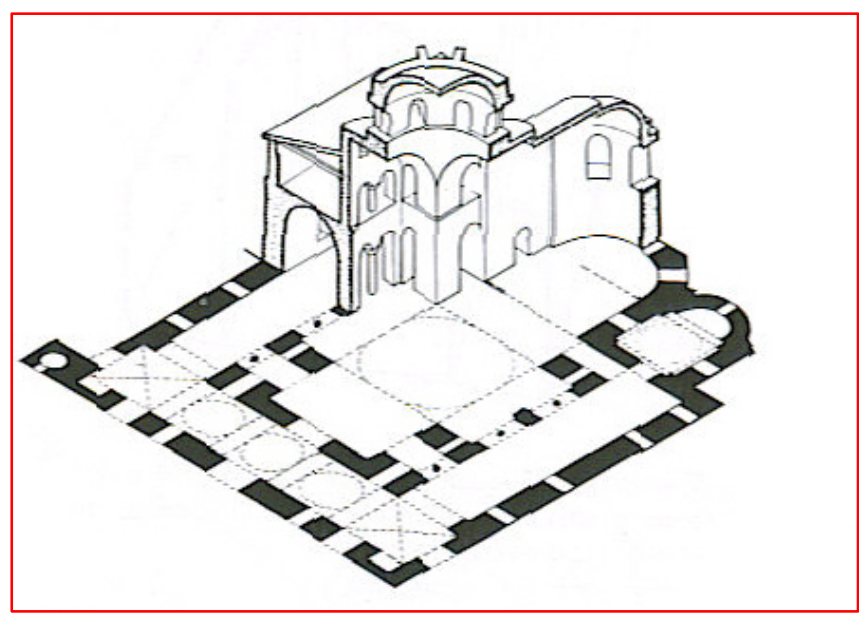
addition of smaller apses) accommodated side altars that were dedicated to the saints. In many instances, the crypt itself was accessible from the body of the church. The use of the fenestrella

Figure 39: Salonika: Hagia Sophia (early $8^{\text {th }}$ c. ?) Ambulatory church with three apses, isometric reconstruction

('small window') confessionis, as seen in the Chapel of S. Vittore in Ciel D’Oro, provided both viewing access, and the possibility of creating contact relics. Finally, the large numbers of pilgrims that traveled to visit a famous saint's shrine inspired the development of church ambulatories, which facilitated the movement of large groups of people.

Altars gradually played into the architectural setting of the cult of the saints. Constantine's architects had focused the building of Old St. Peter's basilica on the aedicula of the saint's burial niche, placing the altar of the church directly above it. Martyrial churches and even small cellae continued this tradition. However, the altar itself gradually became a reliquary. The same logic that extended virtus, saintly power, to 


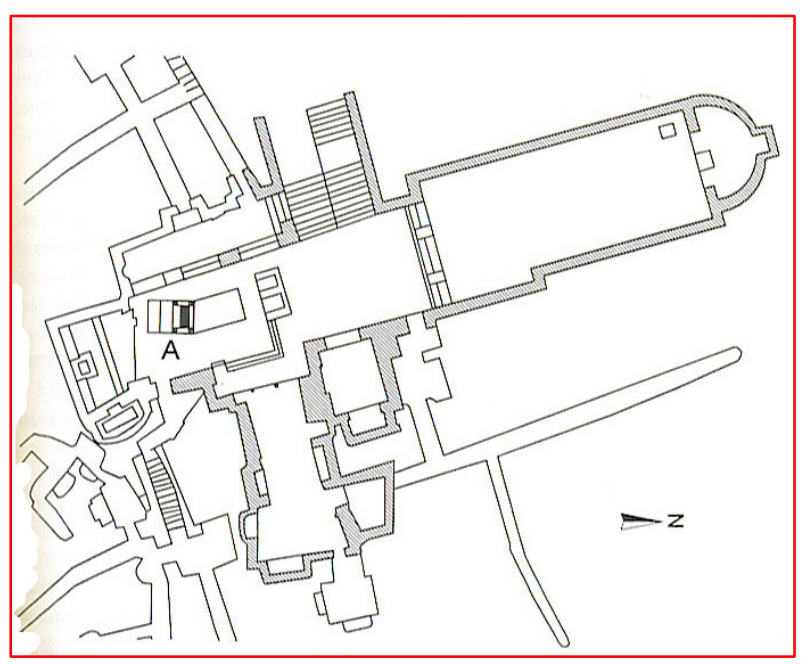

Figure 40: Rome, Cemetery complex of S. Alessandro. A marks the altar (after Belvederi)

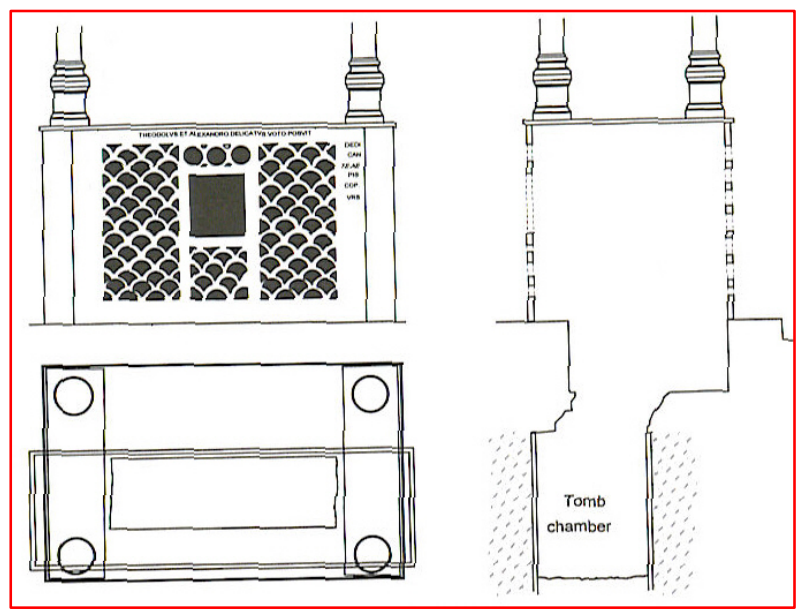

Figure 41: Rome, S. Alessandro. Altar over the tomb of SS. Eventius and Alexander, elevation, plan and section (after Robault de Fleury (1883-9))

contact relics extended to altars as well.

By the fourth century, relics were in

demand for the consecration of churches

and altars; in 402 the Fifth Council of

Carthage ordered that altars that were

not sanctified by the body of a bishop or

the relics of a martyr should be

destroyed if possible. ${ }^{486}$ In the translation of the bodies of Saints Gervasius and

Protasius, Ambrose was able to draw a rhetorical parallel between the presence of Christ super altare and the bodies of the saints sub altare. ${ }^{487}$ The Roman

Ordo of Gregory the Great gives

specific instructions for the embedding of relics within the altar and the altar's consecration. In almost every way, it mimics the liturgy of the burial of the dead. $^{488}$ Eventually, relics were required for altars. The Seventh Council of Nicea (787) forbade the consecration of an altar without relics, under pain of excommunication. ${ }^{489}$

\footnotetext{
${ }^{486}$ Crook, The Architectural Setting of the Cult of the Saints, 13.

${ }^{487}$ Ambrose, Epistolae, xxii. 13.

${ }^{488}$ Crook, The Architectural Setting of the Cult of the Saints, 13.

${ }^{489}$ Crook, The Architectural Setting of the Cult of the Saints, 14.
} 
The link between the altar and the tomb was validated in Revelation 6: 9: "I saw under the altar the souls of them that were slain for the word of God, and for the testimony which they held." By the third century, the Didascalia Apostolorum specifically mentioned the celebration of the Eucharist over the tombs of saints, a passage later echoed in the Apostolic Constitutions. ${ }^{490}$ If one excludes the domus ecclesiae which was usually a co-opted structure, the first pre-Constantinian monumental Christian structures built in Rome were covered cemetery churches. ${ }^{491}$ There Christians could gather for funerals and annual commemorations of their family members' death in the practice of the Roman custom of the refrigerium, the funeral feast, ${ }^{492}$ and celebrate the Eucharist, linked spiritually and dynamically to the tomb of a saint.

One of the most common and most persistent devotions to the saints architecturally was the burial ad sanctos; burial near a saint was thought to confer extra

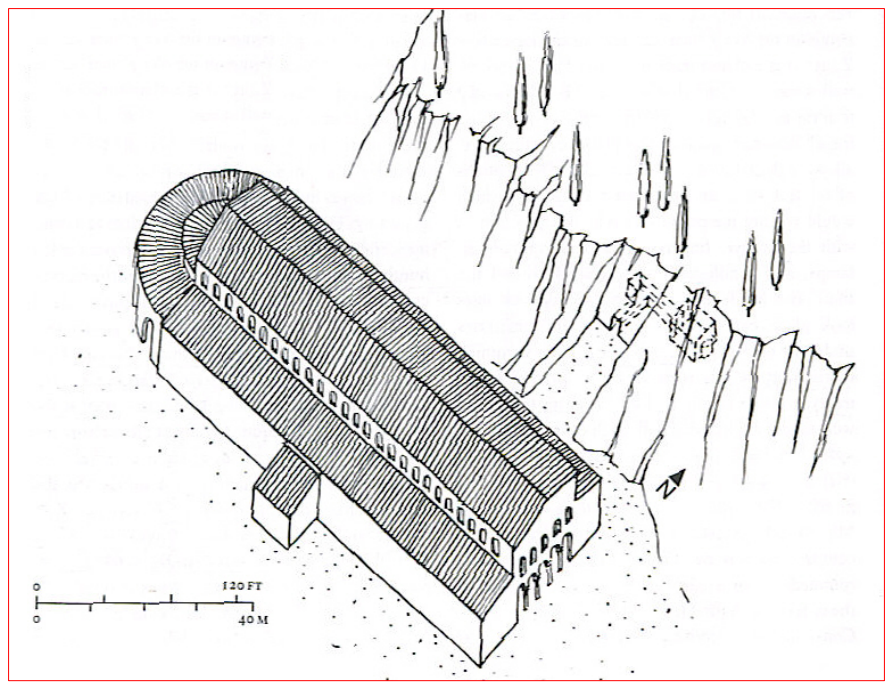

Figure 42: Rome: Isometric reconstruction of S. Lorenzo fuori le mure (c.330) protection for the deceased as well as a share of the saint's holiness (presumably by propinquity). The veneration of relics and the belief in the efficacy of their miraculous powers through the handling by the faithful had an early history and burial ad sanctos was practiced in

\footnotetext{
${ }^{490}$ Crook, The Architectural Setting of the Cult of the Saints, 12. "And offer an acceptable eucharist, the likeness of the royal body of Christ, both in your congregations and in your cemeteries and on the departures of them that sleep."

${ }^{491}$ Krautheimer, Early Christian and Byzantine Architecture, 32.

${ }^{492}$ Lowden, Early Christian and Byzantine Art, 26. For Ambrose's views on the practice of the refrigerium see below, page 134 .
} 
the catacombs of the first through third century, ${ }^{493}$ as indicated by the names of the catacomb cemeteries that were generally regarded as Christian cemeteries: Catacomb of St. Callisto, Catacomb of St. Priscilla, Catacomb of Saints Pietro and Marcellino. Ambrose's desire to be buried between his saints, Gervasius and Protasius, may have been considered presumptuous at the time, but the desire to be buried as closely as possible to the body of a saint had a long history. Ambrose had already established the precedent with the burial of his brother near the body of St. Victor, and the epitaph that he wrote for his brother's grave is a clear indication of the value of burial near a saint:

\section{Uranio Satyro supemum frater honorem Martyris ad laevam derulit Ambrosius. Haec meriti merces ut sacri sanguinis umor Finitimas penetrans adbluat excubias. ${ }^{494}$}

\section{The Finding of Gervasius and Protasius}

In June 386, as he was preparing to dedicate the church that was called the Basilica Martyrum (the Ambrosiana), the congregation demanded that Ambrose dedicate the church as he had dedicated the Basilica Apostolorum earlier that year, i.e., with saints' relics. ${ }^{495}$ Ambrose agreed that he would, if he could find some relics, which, of course, he did, the very next day. The miraculous discovery of the bodies of the martyrs Gervasius and Protasius prior to the dedication of the Basilica Ambrosiana is subject to many interpretations. In his continuing battle with the Empress Giustina and the Arians,

\footnotetext{
${ }^{493}$ John Lowden, Early Christian and Byzantine Art (London: Phaidon Press), 2003, 25: catacomb burial was largely abandoned by the $5^{\text {th }}$ century.

${ }^{494}$ McLynn, Ambrose of Milan, 78: "To Uranus Satyrus, his brother Ambrose Accorded the distinction of burial at the martyr's side. This the reward for his goodness, that the holy blood Should seep through and wash his remains, which lie beside."

${ }^{495}$ Ambrose, Epistolae, xxii. 1. See below, Chapter V "The Ambrosian Foundations," for the discussion of the churches.
} 
there is little doubt that Ambrose capitalized on the discovery of the martyrs as examples of the triumph of the persecuted. ${ }^{496}$ Nor is there any doubt that the palace viewed the entire exercise as a hoax. ${ }^{497}$ Paulinus himself records that these saints were unknown prior to their disinterment. ${ }^{498}$ It was, in fact, a pivotal moment in the history of Ambrose's relationship with Valentinian II which effectively ended the anti-Nicene opposition in Milan.

Ambrose himself has given us a complete account ${ }^{499}$ of the nature of the discovery of these bones in a long letter written to his sister, which merits some scrutiny. ${ }^{500}$ Quite beyond the fact that it was an extraordinarily fortuitous event and useful to Ambrose in his battle with the Empress Giustina to keep the churches of Milan orthodox, several rather tantalizing references emerge to illuminate elements of the fourth century practice of the cult of the saints. In his letter to his sister, Ambrose says that he was inspired ${ }^{501}$ to look for the martyrs in the church of SS Felix and Nabor, but that the identification of the bodies required the assistance of a possessed woman, "on whom hands were to be laid," 502 i.e., Ambrose expected to bless her in an exorcism. "The holy martyrs began driving away [the evil spirit] ${ }^{, 503}$ and she was thrown prostrate on the location of the martyrs. McLynn says that the names of the saints were also revealed at this time by the evil spirit in her, who implored the martyrs to show mercy; Ambrose

\footnotetext{
${ }^{496}$ Dudden, St. Ambrose, 305.

497 Dudden, St. Ambrose, 305.

${ }^{498}$ Humphries, Communities of the Blessed, 55.

${ }^{499}$ Augustine writes of the incident as well, though he appears to have been more impressed by the miracles associated with the finding of the martyrs (Augustine, Confessions, ix. 7). Paulinus also records the event in his Vita Ambrosii.

${ }^{500}$ Ambrose, Epistolae, xxii. See Appendix I for the text of the letter.

${ }^{501}$ Ambrose, Epistolae, xxii. 1 ("At once I was seized, as it were, with a great presentiment of some sort of divine sign").

${ }^{502}$ Ambrose, Epistolae, xxii. 2.

${ }^{503}$ Ambrose, Epistolae, xxii. 2
} 
does not say this, but Augustine adds this amplification. ${ }^{504}$ There was an expectation that the holiness of the martyrs could not abide the presence of the evil spirits who were responsible for possession, who in turn were so tormented in the holy presence that they would leave the vessel of their possession. Relics were expected to cure disease and restore health; this, in fact, was their primary use to the faithful. In the translation of the relics to the Ambrosiana, a man named Severus, who was blind, touched the pall that covered the casket and was cured of his blindness. ${ }^{505}$ This also was an important part of the cult. It was not necessary to have actual access to the bones themselves; anything associated with the saint could be considered a relic. ${ }^{506}$ Ambrose says that he found the bodies "in the spot before the grating ${ }^{507}$ of Sts. Felix and Nabor [the Naboriana]. ${ }^{, 508}$ Several things are suggestive about this statement. The first is that, rather than being buried in the cemetery, the bodies, whoever they might

${ }^{504}$ McLynn, Ambrose of Milan, 212.
${ }^{505}$ Ambrose, Epistolae, xxii. 2.
${ }^{506}$ Dudden, St. Ambrose, 313. Pope St. Gregory I (540-604) specified how relics could be multiplied:

${ }^{506}$ Dudden, St. Ambrose, 313. Pope St. Gregory I (540-604) specified how relics could be multiplied:
"When the Romans give relics of the saints, they do not venture to touch any part of the body; but a cloth is enclosed in a box, which is then placed near the saints' most sacred bodies. This is afterwards taken up and deposited in the church which is to be dedicated, and the miracles wrought by it are as great as if the very bodies of the saints had been brought there. Whence it came to pass that in the time of Pope Leo of blessed memory, when certain Greeks doubted the efficacy of such relics, the pontiff, according to the tradition handed down by our ancestors, took a pair of scissors and cut the cloth, and as he cut it blood flowed out' (Gregory I, Epistolae, iv. 30).

${ }^{507}$ McLynn, Ambrose of Milan, 212. Some translations read 'chancel railing,' which is what McLynn has used. Dudden (St. Ambrose, 299) uses 'railing or screen.' The Catholic Encyclopedia translates it as 'chancel screen.' Sister Mary Beyenka's translation reads, 'before the grating,' which I believe is probably the most accurate reading (Ambrose, translated by Sister Mary Melchior Beyenka, O.P. Letters (NY: Fathers of the Church, Inc.,) 1954, 376). While this point may be of small interest to the historian of Ambrose, it is of immense interest to the art historian examining the architecture of $4^{\text {th }}$ and $5^{\text {th }}$ century Italian churches. There is no way that we can know; Krautheimer equivocates in his examination of S. Tecla, referring to the 'chancel barrier (See above, page 59).' But the use of a chancel screen, which became a fixture in Byzantine churches in the East in the $6^{\text {th }}$ and $7^{\text {th }}$ centuries, a structure that effectively shielded the altar from the view of the congregation, would have been unusual in northern Italy and extremely unusual in this small martyrial church. The term 'grating' however, is perfectly reasonable, representing as it would the opening of a fenestrella confessionis. As applied to the delicate art of translation, we would be well-advised to consider the maxim caveat emptor.

${ }^{508}$ Ambrose, Epistolae, xxii. 2. Paulinus records this as: "ambularant omnes qui vellent ad cancellos pervenire quibus sanctorum Naboris et Felicis martyrum ab iniuria sepulcra defendebantu, (McLynn, Ambrose of Milan, 211, citing Paulinus, Vita Ambrosii, 14. 1)." 
have been, had indeed been buried ad sanctos within the church and in the vicinity of the altar. Additionally, Ambrose described the bodies as decapitated, in good condition, although he says that "there was much blood;",509 the inference is that the bodies were interred hastily, perhaps surreptitiously, without being cleaned or prepared for burial, and there could be no doubt that they were martyrs, since their heads were severed from the bodies. He also says that they were of "... marvelous stature, such as those of ancient days." ${ }^{\circ 10}$

The identification of the saints ("Old men now repeat that they once heard the names of these martyrs and read their titles") $)^{511}$ is ultimately a non sequitur. The pseudoAmbrosian letter De inventione sanctorum Gervasii et Protasii ${ }^{512}$ states that they were the twin sons of St. Vitalis and Sta. Valeria, who having lost their parents, were martyred by a Count Astasius, who had ordered them to make a sacrifice to the gods for a successful expedition against the Marcomanni. However, none of this information appears in Ambrose, who along with Augustine and Paulinus states that their memory had died out in Milan ("Our eyes were closed as long as the bodies of the saints lay hidden under cover"). ${ }^{513}$ It is possible that the bodies were in some way associated with

\footnotetext{
${ }^{509}$ Ambrose, Epistolae, xxii. 2.

${ }^{510}$ Ambrose, Epistolae, xxii. 2. Dudden, in an unusual, fugue-like venture into the realm of the preposterous, cites the hypothesis of Salomon Reinach that the skeletons were prehistoric remains that had been coated in red ochre, and that the heads had been severed because of primitive fear of the vampire (Dudden, St. Ambrose, 307 citing S. Reinach, Orpheus (1909) 111, 112 (the work is not included in Dudden's bibliography).

${ }^{511}$ Ambrose, Epistolae, xxii. 12.

${ }^{512}$ Dudden, St. Ambrose, 319. Inserted by the Benedictines in their edition of Ambrose's Works (743-7), it purports to have been written by Ambrose to the bishops of Italy. It was known to John Damascene (c. 676 to 754-787) who refers to it.

${ }^{513}$ Ambrose, Epistolae, xxii. 11.
} 
St. Felix and St. Nabor; perhaps they too were Mauritanian soldiers who were martyred at the same time (or shortly thereafter) in Lodi. ${ }^{514}$

Ambrose used the discovery of these unknown martyrs to maximum effect in promoting his own agenda of eliminating heresy in Milan and disarming the very real threat to him personally from the imperial family. But he could not have done this without the cooperation of the people of Milan, whose own avidity for saints' relics precipitated the entire event. Even McLynn, who believes that Ambrose was a consummate stage manager, ${ }^{515}$ feels that it would have been very difficult for the bishop, if not impossible, to stage manage every detail of the finding of these martyrs, which the Empress Giustina derided as "the theatrical representations which were exhibited by the contrivance, and at the expense, of the bishop." ${ }^{, 516}$ We may interpret the effects, but we cannot play with the essentials. McLynn writes: "It requires an Ambrose both improbably villainous and anachronistically enlightened, for the metaphor upon which it depends is flawed. The fourth century cult of the martyrs was not a pantomime staged for the vulgar but a channeling of powerful energies too intractable for the bishop to have controlled at will, and too pervasive for him to have thought to try.",517

The cult of the saints remained a tenet of medieval Christianity that, in many instances, overshadowed the message of the Gospel that was ostensibly the central focus of the religion. For whatever use and abuse was made of it by bishops and priests, the enthusiasm and the implied connivance of the faithful never wavered; it remained a grass-roots phenomenon that was far more central to the religious life of the medieval

\footnotetext{
514 See page 63.

${ }^{515}$ McLynn, Ambrose of Milan, 376.

${ }^{516}$ McLynn, Ambrose of Milan, 215, citing Edward Gibbon, The Decline and Fall of the Roman Empire, ed. J. B. Bury (1909), 3: 169.

${ }^{517}$ McLynn, Ambrose of Milan, 215-216.
} 
Christian than the mystery of the Trinity. Periodically it required theological

tweaking ${ }^{518}$ the last great tweaking split the Church when Martin Luther nailed his

Ninety-five Theses to the door of a church in Germany on the thirty-first of October, 1517.

\footnotetext{
${ }^{518}$ Dudden, St. Ambrose, 309. Ambrose argued that not only martyrs and saints could intercede for those on earth, but also noble spirits (Ambrose, De excessu Sat. ii. 135, De obitu Val. 41, De obitu Theod. 16). Jerome notes that if their prayers while they suffered were powerful, how much more potent they must be having "won their crowns" (Jerome, Contra Vigilante, 6). Augustine says that since we sinners on earth are unworthy to ask and receive blessings from God Himself, we may ask him "through His friends" (Augustine, Serm. 332.3).
} 
CHAPTER V

THE AMBROSIAN FOUNDATIONS

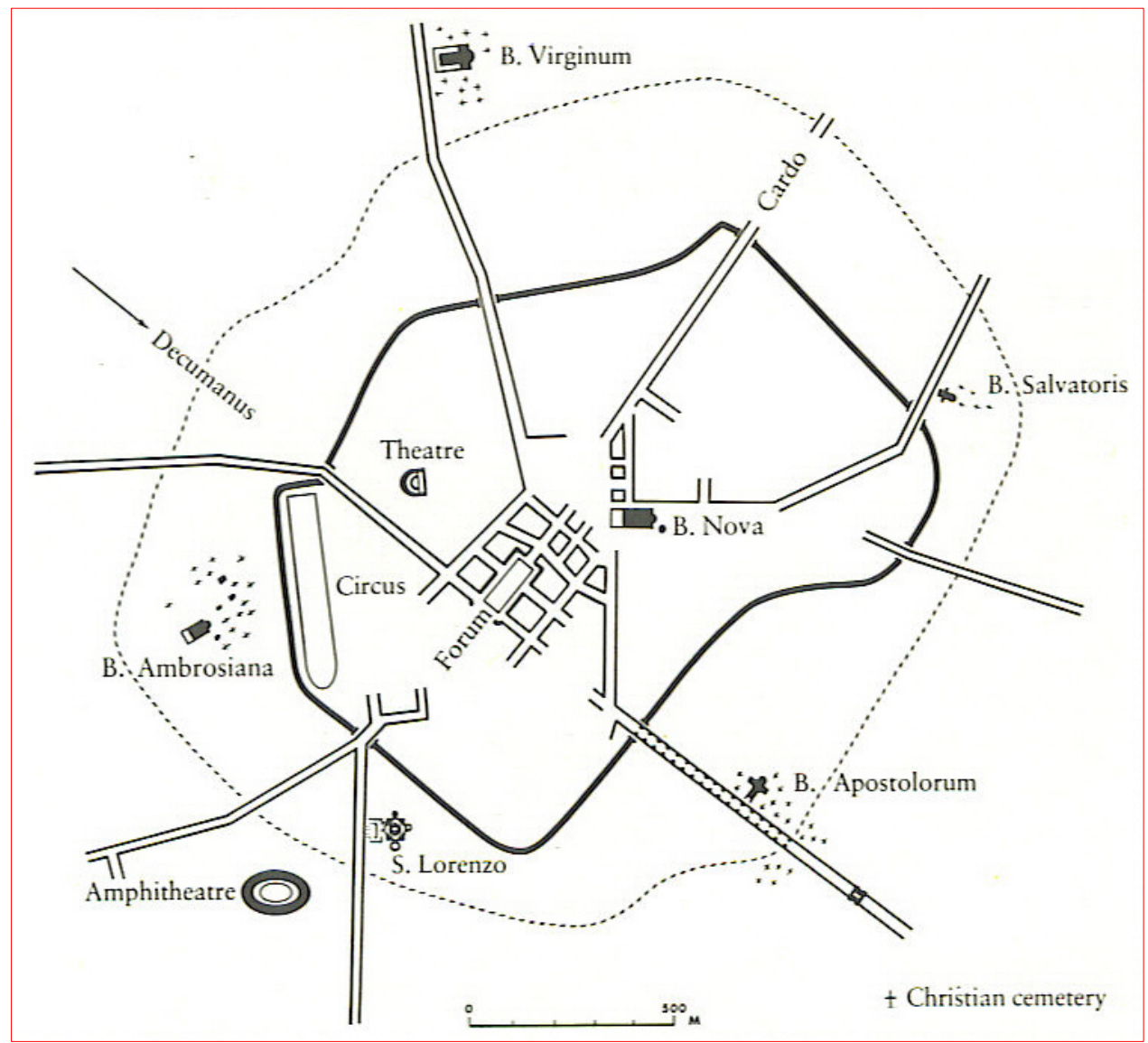

Figure 43: Milan, c. 400

Within a few years of his election ${ }^{519}$ Ambrose began building a large basilica in the Coemeterium ad Martyres outside Maximian's walls at the Porta Vercellina, adjacent to the small oratory of S. Vittore in Ciel D'Oro where he had buried

${ }^{519}$ Edwards (Lewis), "Two Critical Aspects of Fourth-Century Architecture at Milan," 90. Possibly as early as 379 . 
his brother Satyrus in 375 . The laying of the foundations of this large church, the

Basilica Martyrum, inaugurated a building program that would grace Milan with at least

three monumental churches, possibly four. The Basilica Apostolorum, located near the

Porta Romana was built between $380-386 ;{ }^{520}$ a third church, the Basilica Virginum was

begun in the last years of Ambrose's life and was completed within a few years after his

death in $397 .^{521}$ A fourth church, the Basilica Salvatoris is also linked to Ambrose, but

the identification of this church with the medieval church of S. Dionigi (now lost) is

speculative. ${ }^{522}$ Additionally, Ambrose is credited with the construction of the baptistery

of S. Tecla, S. Giovanni alle Fonti. ${ }^{523}$

As can be seen from the map which begins this chapter, Ambrose's churches were

all located in suburban cemeteries, forming a crown surrounding the city, all in the

vicinity of Milan's most important gates. While it is tempting to infer from Ambrose's

placement of his churches that he expected to grace Milan with a complement of

${ }^{520}$ Suzanne Lewis, "The Latin Iconography of the Single-Naved Cruciform Basilica Apostolorum in Milan," Art Bulletin, 51 (1969): 208.

${ }^{521}$ His successor, Bishop St. Simpliciano, who died in 401 was interred there. The church was subsequently re-dedicated to him.

${ }_{522}$ Edwards (Lewis), "Two Critical Aspects of Fourth-Century Architecture at Milan," 102. A $13^{\text {th }}$ century tradition attributed a basilica dedicated to the prophets of the Old Testament, B. Salvatoris, located at the Porta Argentea in the vicinity of the Concilia Sanctorum (northeast quadrant) as an Ambrosian foundation. Calderini considers this to have been entirely plausible, since it would have formed an apposite structure for the Basilica Apostolorum, dedicated to the New Testament Apostles, and it would have completed a topographical program that included suburban churches at all the major gates of Milan. Additionally, we know that Ambrose had the remains of Bishop St. Dionysius returned to Milan from Cappadocia, where he had died in exile. It would have been fully consonant with the Ambrosian agenda of the triumph of proNicene orthodoxy and the promotion of the cult of the saints for Ambrose to have constructed a church enriched by the relics of the bishop that Ambrose considered a martyr to the cause of both orthodoxy and the separation of secular authority (the imperial family) from the administration of the Church. Edwards (Lewis) indicates that it may have had a plan similar to B. Virginum (note 122, 133). See also Jean-Michel Speiser, "Ambrose's Foundations at Milan and the Question of Martyria," Urban and Religious Spaces in Late Antiquity and Early Byzantium (Burlington, VT: Ashgate Publishing Company), 2001, 5, who locates the B. Salvatoris as S. Donigi, east of the Porta Argentea.

${ }^{523}$ Krautheimer, Three Christian Capitals, 77 (note 33, 148), is not entirely convinced that the baptistery belongs to the Ambrosian period, based upon the high quality of its masonry, which suggests that it was built under the imperial patronage that constructed S. Tecla. However, we know that Augustine was baptized in the baptistery that was attached to the basilica vetus in April 387 (Dudden, St. Ambrose, 713); it seems unlikely that Ambrose would have continued to baptize in the old baptistery had he had the convenience of S. Giovanni alle Fonti so close to the cathedral. 
monumental structures that would rival the Constantinian foundations of Rome, that conclusion is only superficial. Each of these churches represents a response, politically, theologically, and liturgically (and ultimately, architecturally), to the Ambrosian program of extending the hegemony of the see of Milan.

However, they do share some aspects which unite them beyond their initial placement. They were all, as has been noted, located in cemeteries outside the walls, but they were neither conceived nor built as cemetery churches. Ambrose found the Roman practice of the refrigerium, the traditional cemetery feast of commemoration of the dead, distasteful. The celebration, which Ambrose perceived as a relic of paganism, ${ }^{524}$ had deteriorated functionally from its original spirit and had become an excuse for drunkenness and riotous behavior, ${ }^{525}$ Ambrose prohibited the celebration and posted guards to enforce his prohibition. Augustine relates that, when his mother arrived at the cemetery with the traditional gifts of cake, bread, and wine to honor the memorials of the dead (as had been her custom at home), she was turned away by a guard who told her that the bishop had forbidden it (Augustine, Confessions, 6.2.2). ${ }^{526}$

The fact that the churches were placed in cemeteries, the traditional placement for Christian churches in Rome, was to a certain extent, incidental. Ambrose had no need, as Constantine did, to site his churches so as not offend pagan sensibilities; his cathedral in the heart of the city had already defined Milan as a Christian capital. The location of the cemeteries offered the availability of sufficient space, and the churches, aligned as they

\footnotetext{
${ }^{524}$ Dudden, St. Ambrose, 250. Tombs of adherents of the cult of Isis frequently included the inscription 'May Osiris give thee the water of refreshment' which suggested the Christian designation of tombs as 'refrigerii sedes,' the place of refreshment, and McLynn, Ambrose of Milan, 236, who alleges that Ambrose viewed the refrigerium as a "disguised version of the feast of the dead, the Parentalia."

${ }^{525}$ McLynn, Ambrose of Milan, 237: “...the surburban cities of the dead, so often a source of deviance and dissent..."

${ }^{526}$ McLynn, Ambrose of Milan, 236.
} 
were on the rough north-south and east-west axes of the city, appear to have been sited to address the congregational needs of the vastly increased population ${ }^{527}$ that Milan experienced during the period of imperial residency. The Basilica Virginum, the largest of the churches, was placed far to the north, an area that had almost no early Christian presence. Largely because of its vulnerability as the first line of attack from the north, the area appears to have been relegated to the imperial military units, who, as group, traditionally followed the cult of Mithras. ${ }^{528}$

However, as will be shown, the location of the Basilica Apostolorum served very

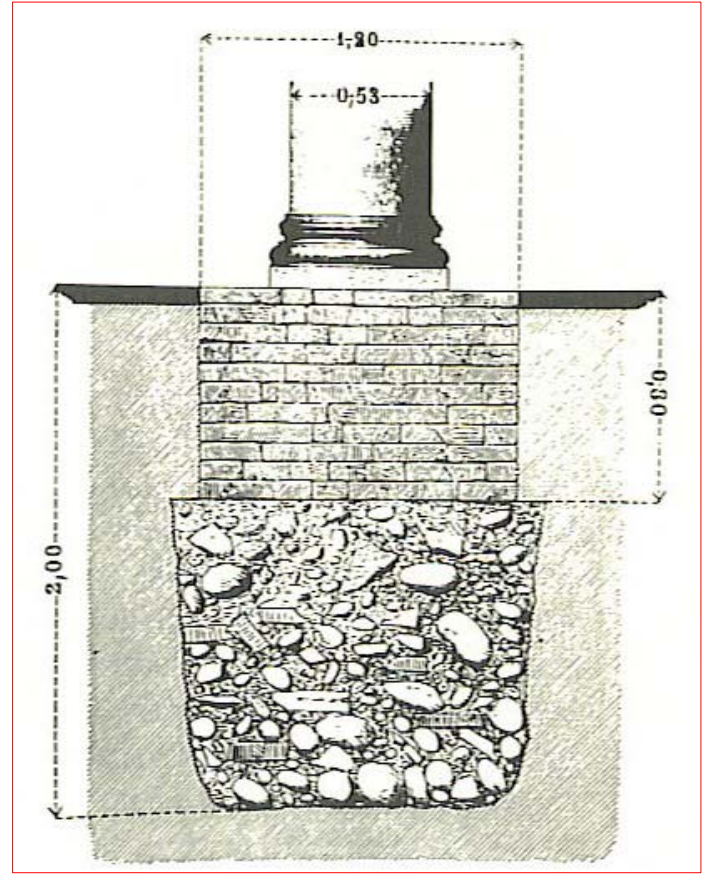

Figure 44: Milan: Sant' Ambrogio (B. Martyrum), foundation of $4^{\text {th }}$ c. column specific ideological and political purposes.

The cemetery associated with it appears to have been undifferentiated with both pagan and Christian burials. ${ }^{529}$ Only the Coemeterium ad Martyres, where Ambrose placed his first foundation, could claim to be an exclusively Christian cemetery of some antiquity. In choosing that holy site for his first foundation, the outsider bishop sought to bind himself firmly to his Milanese flock. As such, the purpose of the locations of Ambrose's churches must necessarily

\footnotetext{
${ }^{527}$ Krautheimer, Three Christian Capitals, 71. Ausonius estimated the population of Milan as between $130,000-150,000$ in 385 . Krautheimer doubts that it was that much, but it was a significant city. Nevertheless, congregational requirements for Ambrose's churches remain a small consideration, and a slippery one; the motives behind their construction relegate this factor to the bottom of the list.

${ }^{528}$ Dudden, St. Ambrose, 250. Dudden notes additionally that in northern Italy, the principle strongholds of Mithraism were in Milan and Aquileia, both imperial capitals (251, note 1).

${ }^{529}$ Edwards (Lewis), “Two Critical Aspects of Fourth-Century Architecture at Milan,” 101.
} 
transcend simple congregational requirements (although the bishop himself justified his church-building for just that reason).

In addition to their locations at city gates and in cemeteries, the churches share similarities in the nature of their construction. Ambrose was building quickly, and he did not have the use of unlimited funds that characterized the imperial foundation of S. Tecla. Each of the churches has pebble foundations, composed of 'disorderly ${ }^{530}$ mixtures of pebbles, broken bricks, and discarded tiles (Figure 44). All were built with brick, frequently with reused bricks, and the high mortar beds do not show the even placement of bricks and thin mortar beds that characterized the fine work of S. Tecla. ${ }^{531}$ Instead, a characteristic herringbone pattern of masonry, opus spicatum, is interspersed in the surrounding mortar work (Figures 45 and 46), a feature that easily identifies all three foundations as Ambrosian. While Krautheimer acknowledges that building techniques could have changed in the period of time between the construction of S. Tecla and the Ambrosian basilicas, the use of this style of masonry suggests a need to build both quickly and economically. ${ }^{532}$

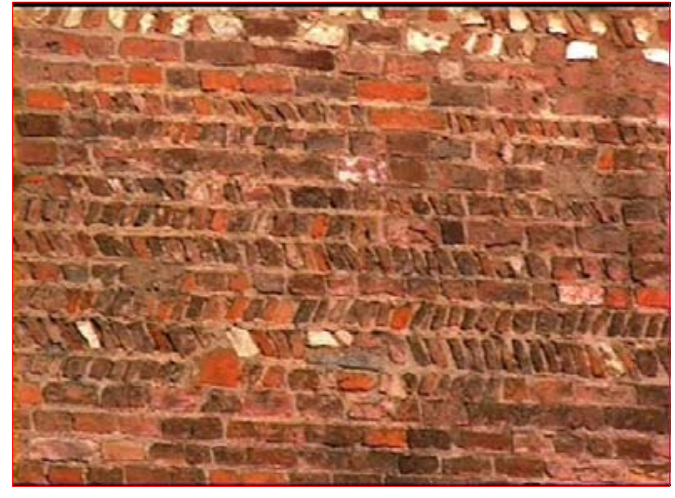

Figure 45: Milan: Sant'Ambrogio (B. Martyrum), $4^{\text {th }}$ c. opus spicatum masonry

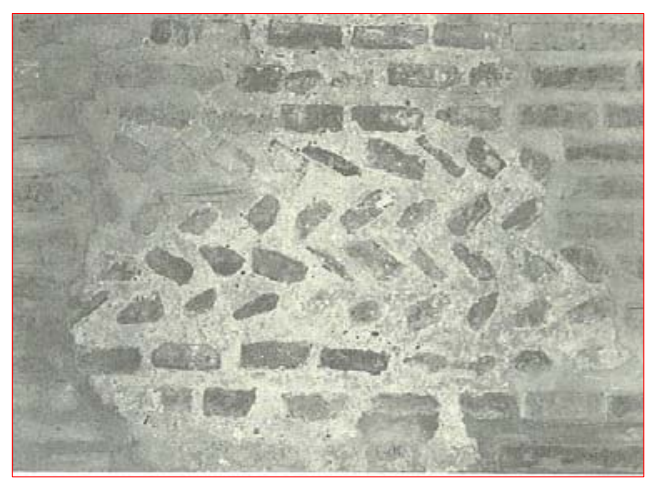

Figure 46: Milan: S. Simpliciano (B. Virginum), $4^{\text {th }}$ c. opus spicatum masonry

\footnotetext{
${ }^{530}$ Krautheimer, Three Christian Capitals, 77.

${ }^{531}$ Krautheimer, Three Christian Capitals, 79.

${ }^{532}$ Krautheimer, Three Christian Capitals, 79. Actually, B. Virginum is an exception. See below.
} 
Finally, though all of the churches were essentially martyrial, promoting in one way or another the cult of the saints, none of them was built specifically to liturgically effect the devotions associated with that cult. Ambrose used the cult of the saints and the translation of relics to these churches to actualize and facilitate a purpose that he had already defined intellectually: promoting pro-Nicene orthodoxy in Milan and northern Italy. Suzanne Lewis writes: “The introduction of martyrs' relics in these structures was plainly secondary, serving merely to enhance the sanctity of their congregational context. ${ }^{, 533}$

Although the political, theological, and liturgical ramifications of the construction of the B. Martyrum and the B. Apostolorum are entwined in their almost simultaneous dedication in the spring of 386, in the discussion of Ambrose's foundations I have elected to follow the evolution of Ambrose's architectural style by beginning with the B.

Martyrum. The fact that the church was started earlier but dedicated later than the B. Apostolorum disturbs the orderly process of the methodology, since some aspects of its dedication refer to the dedication of the younger church. Nevertheless, I feel that this approach will be more useful as we continue the examination of the derivative foundations.

\section{The Basilica Martyrum}

There is very little documentary evidence ${ }^{534}$ and only a scant vestige of the fourth century fabric of this church which was called (almost immediately) the Ambrosiana ${ }^{535}$

\footnotetext{
${ }^{533}$ Suzanne Lewis, "Problems of Architectural Style and the Ambrosian Liturgy in Late Fourth Century Milan," Hortus Imaginum: Essays in Western Art, ed. Robert Enggass and Marily Stokstad. Lawrence, KS: University of Kansas, 1974, 15.

${ }^{534}$ Edwards (Lewis), "Two Critical Aspects of Fourth-Century Architecture at Milan," 91. The first real documentary evidence (other than Ambrose's letter concerning the finding of the martyrs) occurs during the episcopate of Bishop Angilbertus II (824-859), when the basilica was substantially rebuilt.
} 
and which became the present church of Sant'Ambrogio, a Romanesque renovation $c a$. 1100. The remains of the Ambrosian basilica were uncovered by Landriani during a major restoration of the church begun in 1869 and completed in 1880. Landriani was able to develop the plan for the basilica based upon his discovery that the west wall and the lateral walls coincided with the present church; this conclusion was verified by the excavations of Reggiori carried out between 1929 and $1940 .^{536}$

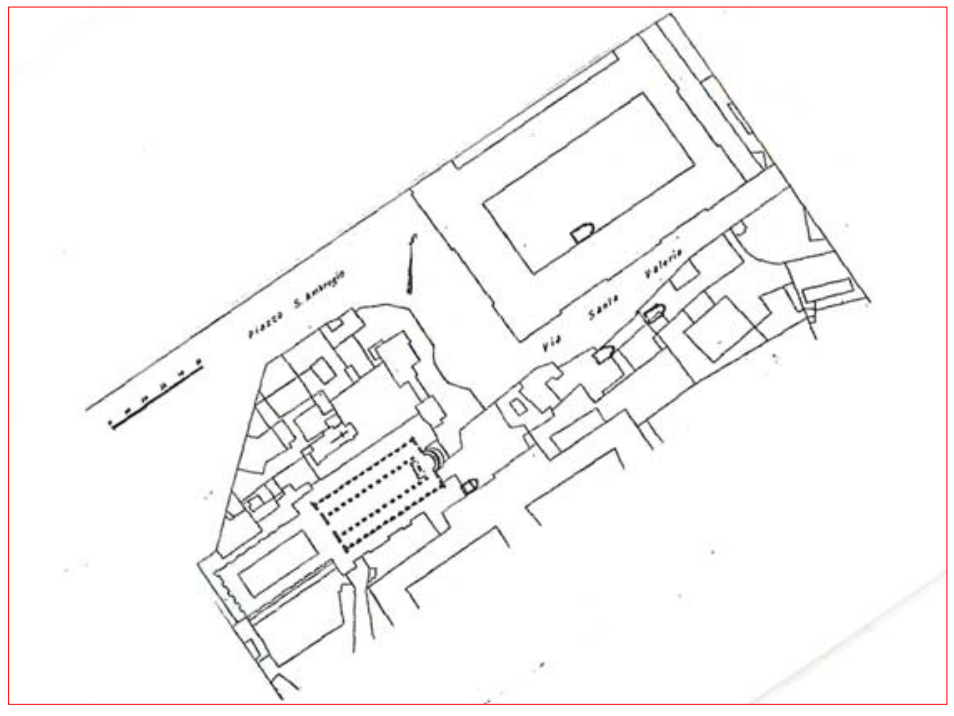

Figure 47: Milan: B. Martyrum in the Coemeterium ad Martyres, 386
It is difficult to attribute pastoral consideration for the suburban population's congregational needs to Ambrose in the building of his first church. The strange northeast-southwest orientation of the building was obviously meant to accommodate the small chapel of S. Vittore in

Ciel d'Oro where he had interred his brother. With this church, Ambrose meant to establish himself in the city of Milan, placing himself and his family in the most venerable and holy area of the city, close to the Milanese martyrs. His subsequent announcement that he intended to be buried beneath the altar was shocking and recalled

\footnotetext{
${ }^{535}$ Edwards (Lewis), "Two Critical Aspects of Fourth-Century Architecture at Milan," 91: Augustine, Paulinus, and Gregory of Tours all refer to the deposition of the martyrs Gervasius and Protasius in the "basilica quae dicitur Ambrosiana."

${ }^{536}$ Edwards (Lewis), “Two Critical Aspects of Fourth-Century Architecture at Milan,” 93.
} 
Constantine's vision of himself as the Thirteenth Apostle. ${ }^{537}$ This, in effect, was a statement to his enemies (the imperial court of Valentinian II and his mother, the Dowager Empress Giustina) that, should they choose to martyr him to the cause of orthodoxy, his people of Milan would have a focus for their continued loyalty to his principles and to his theology. Ambrose's explanation of this novel idea was remarkably urbane: a bishop should be buried where he served, which, of course, wasn't exactly true; the bishop served in the cathedral. ${ }^{538}$ Nevertheless, the continuing criticism of the antiNicene faction over the misuse of church funds forced Ambrose to defend his churchbuilding. ${ }^{539}$ The demand by his congregants that he dedicate the church with the

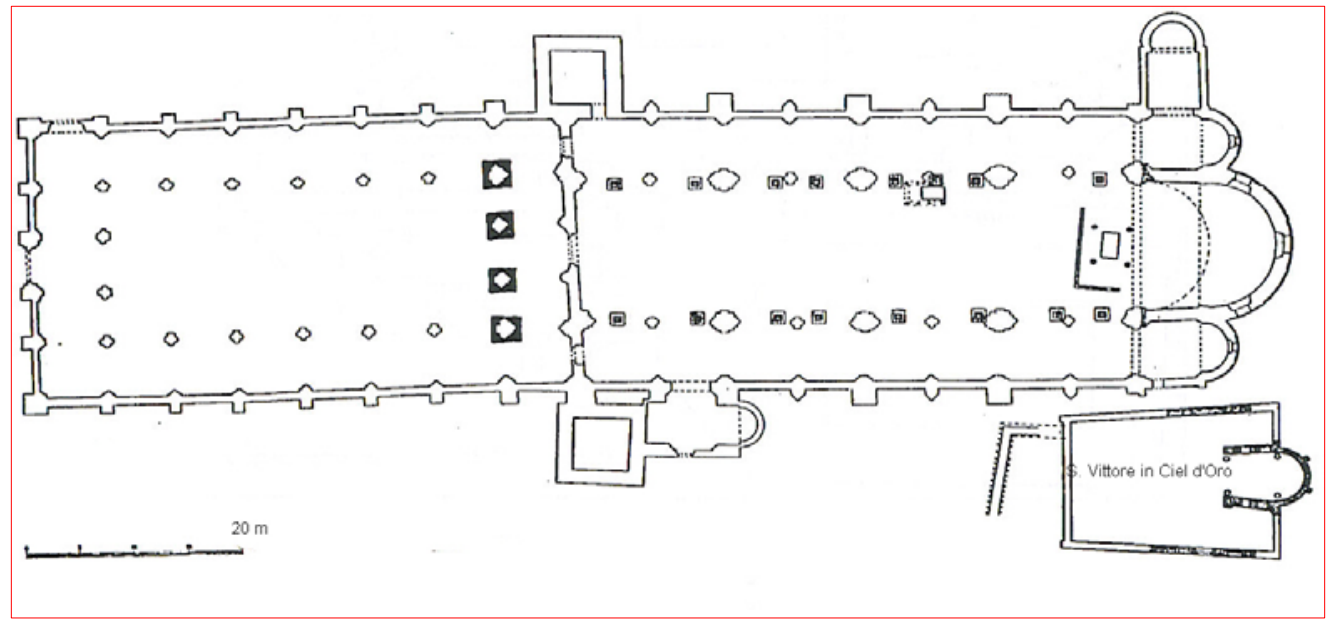

Figure 48: Milan: B. Martyrum (Sant'Ambrogio) $4^{\text {th }}$ c. plan showing the atrium and chapel of $\mathrm{S}$. Vittore in Ciel d'Oro, as well as the original apse and altar placement

relics of martyrs, ${ }^{540}$ as he had dedicated the B. Apostolorum, and his assent to that demand with the miraculously opportune discovery of the relics of Gervasius and

\footnotetext{
${ }^{537}$ See below in the section on the B. Apostolorum.

${ }_{538}^{53}$ McLynn, Ambrose of Milan, 56.

${ }^{539}$ McLynn, Ambrose of Milan, 56. Ambrose wrote in De officiis 2.142: "nemo potest indignari, quia humandis fidelium reliquiis spatial laxata sunt. ('They [the opposition of the homoians] are complaining indignantly...the provision of burial for the faithful can be presented as a work of humanity.')" There is every indication that Ambrose used his own funds in the construction of this church, but since he had donated his property to the see of Milan, he was under the constraint of accounting for the use of Church funds.

${ }^{540}$ See above, Chapter IV, "The Cult of the Saints."
} 
Protasius eliminated the carping on all fronts. There could be no opposition to the appropriate burial of these Milanese martyrs in a fitting martyrium, and who better to be buried with them than the holy bishop who was inspired to find them and revive their cult?

Ambrose's first exercise in architecture was undistinguished: the church is a very run-of-the mill Constantinian basilica with a hypostyle nave flanked by two aisles. Nevertheless, there is no doubt that it was richly furnished. The two lateral aisles were disposed by arcades composed of sixteen columns unequally distributed so that the nave consisted of a double order of thirteen columns, which are duplicated in the Romanesque piers of the present church; Edwards (Lewis) notes that since all of the column fragments

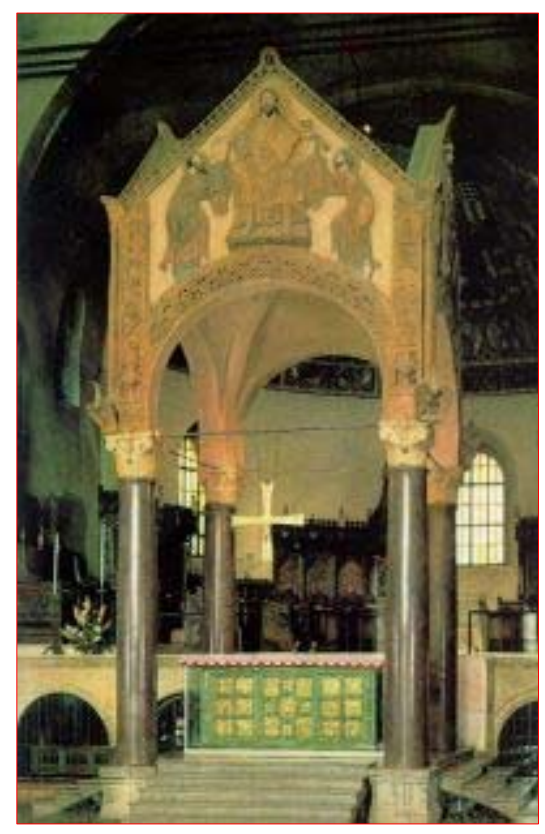

Figure 49: Milan: Sant'Ambrogio, the altar and ciborium $\left(11^{\text {th }} \mathrm{c}.\right)$ found in the excavations under the present basilica were Corinthian, we can safely assume that the columns were of this order uniformly. ${ }^{541}$ On the basis of two column bases which survived from the nave columns, Landriani was able to extrapolate that the diameter of these columns could not have exceeded 53 $\mathrm{cm} .{ }^{52}$ Additionally, the two engaged columns of the triumphal arch of the apse survive in situ to a third of their original height and are of antique marble (spolia); one of rose-colored African breccia, the other

\footnotetext{
${ }^{541}$ Edwards (Lewis), "Two Critical Aspects of Fourth-Century Architecture at Milan," 92.

${ }^{542}$ Edwards (Lewis), "Two Critical Aspects of Fourth-Century Architecture at Milan," 92.
} 
of verde antico. These columns are slightly larger, being almost $60 \mathrm{~cm}$ in diameter. ${ }^{543}$

The four columns which support the ciborium are of porphyry and were also part of the original church; apparently, the presbytery was not raised above the nave since their

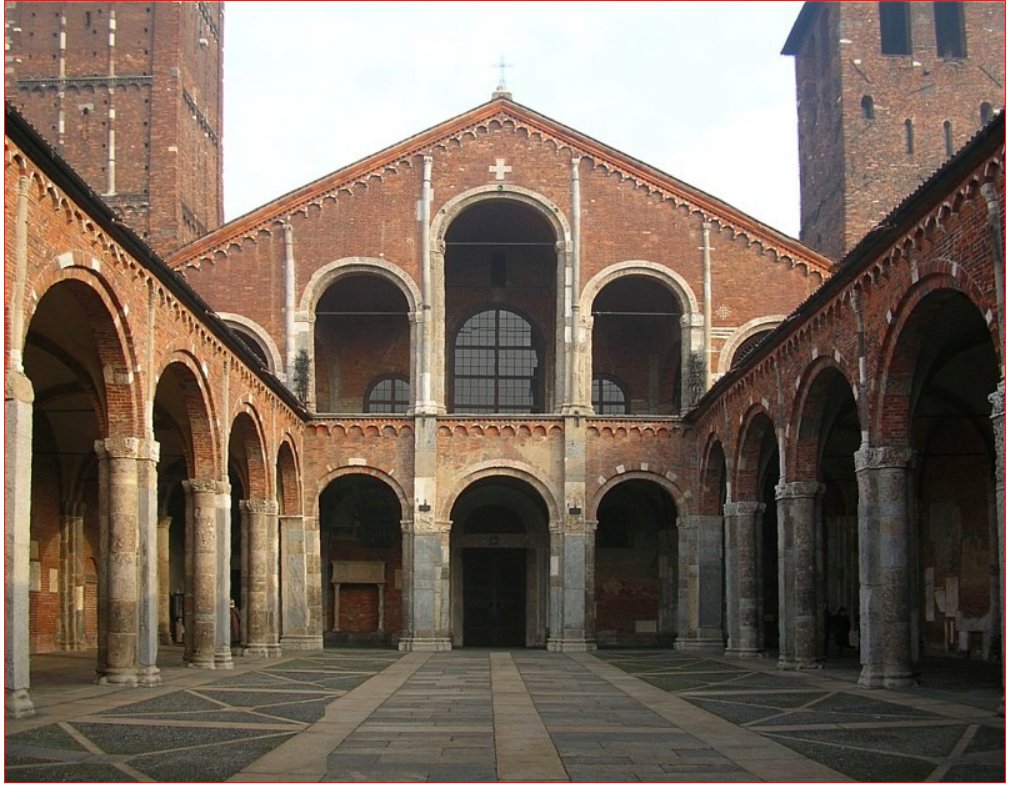

marble bases rest on the

same level as the two

surviving bases of the nave

columns.

Relative to the

massiveness of the

cathedral of S. Tecla, the

church was only about half

Figure 50: Milan: Sant'Ambrogio, west wall showing the forecourt

as big $(26 \mathrm{~m}$. wide by 53.40

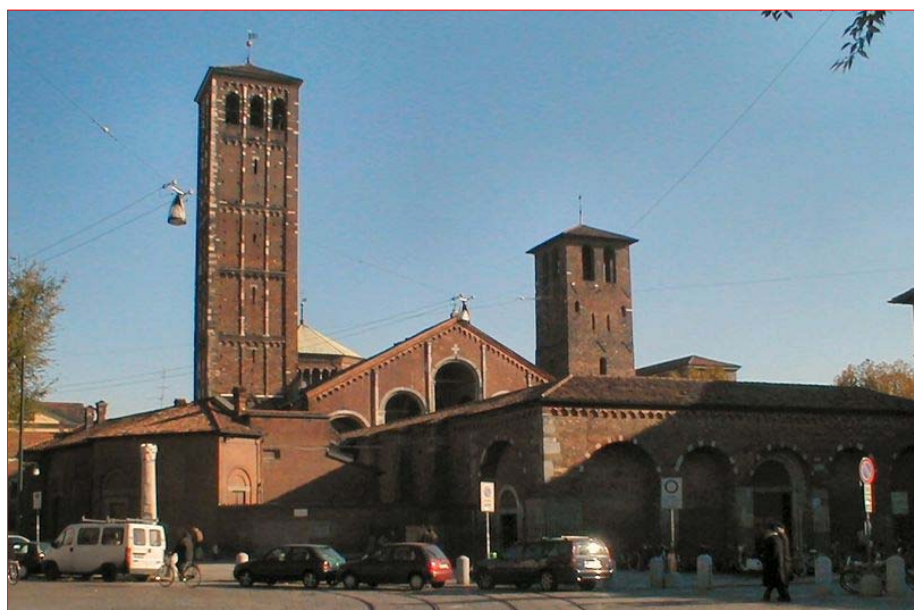

$\mathrm{m}$. long from the triumphal arch

to the present west wall). The

central nave measured $12.50 \mathrm{~m}$.

wide and the side aisles $6.22 \mathrm{~m}$.,

a proportion of exactly two to

one. $^{544}$ While some

$\operatorname{archeologists}^{545}$ believe that the

Figure 51: Milan: Present day Sant'Ambrogio complex

magnificent forecourt that adorns the

present day Sant'Ambrogio is the original fourth century atrium, the documentary

\footnotetext{
${ }^{543}$ Edwards (Lewis), "Two Critical Aspects of Fourth-Century Architecture at Milan," 92.

${ }^{544}$ Edwards (Lewis), "Two Critical Aspects of Fourth-Century Architecture at Milan," 93.

${ }^{545}$ Edwards (Lewis), "Two Critical Aspects of Fourth-Century Architecture at Milan," 130, note 96:

Verzone and Capitani d'Arzago agree that the present forecourt repeats the plan of the original Ambrosian atrium.
} 
evidence indicates that it was built ex nova in the ninth century by Bishop Anspertus (873-881); there is, therefore, a possibility that it may have been absent in the plan of the original church. ${ }^{546}$

Since Reggiori found traces of the original apse on the northeast side, constructed of opus latericum that matches both the B. Apostolorum and B. Virginum, he has concluded that the church was a three-aisled basilica, the nave of which terminated in a single apse attached directly to the nave, which was introduced by a triumphal arch which both defined and connected the two elements. There was no transept, and the apse was perhaps raised two steps from the level of the nave, and would have included the synthronon for the clergy. ${ }^{547}$

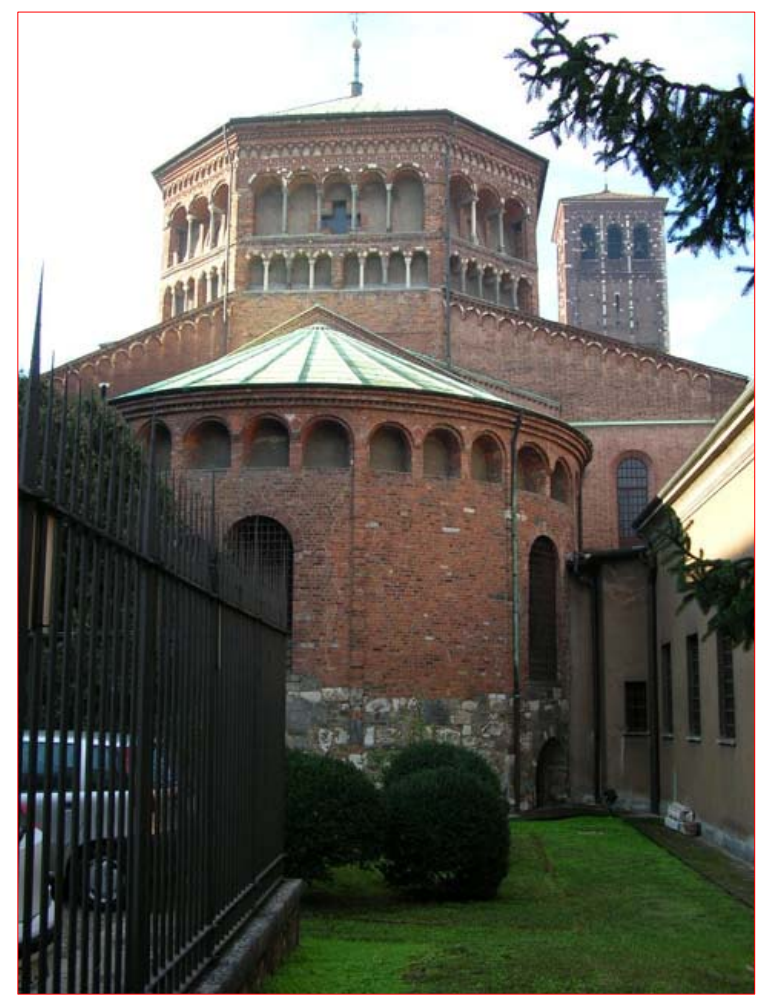

The altar, which covers the tombs (Ambrose indicated in his letter to Marcellina that the martyrs were to be buried on the right, while he was destined for the left, i.e., the north side of the altar), ${ }^{548}$ was originally probably a simple mensa; it has since be replaced by the magnificent golden altar of Bishop Angilbertus II (824-859) and Wolvinus. However, its location, above the tombs

Figure 52: Milan: Sant'Ambrogio, northeast wall and apse

\footnotetext{
${ }^{546}$ Edwards (Lewis), "Two Critical Aspects of Fourth-Century Architecture at Milan,” 93.

${ }^{547}$ Edwards (Lewis), "Two Critical Aspects of Fourth-Century Architecture at Milan," 94. He is actually resting between them (See Figure 5)

548 Ambrose, Epistolae, xxii, 13.
} 
has never been changed, ${ }^{549}$ and the four porphyry columns of the present ciborium must have supported the original canopy. ${ }^{550}$ Edwards (Lewis) indicates that the entire sanctuary area in front of the triumphal arch was "closed off from the rest of the nave by marble chancels." ${ }^{, 51}$ The building's roof and ceiling were covered by open, trussed timber. $^{552}$

Liturgically, this church served as a congregational church, and the liturgy would have been enacted as the normal Sunday celebration indicated above, possibly including the weekday offices as well. However, without a baptistery (and in fact, none of the Ambrosian foundations have attached baptisteries), the Easter celebrations would have been reserved for the cathedral. Here then, in the Ambrosiana, there is every indication that the entire architectural and liturgical thrust of this church was martyrial. Its orientation was manipulated to accommodate itself to the small oratory of S. Vittore in Ciel d'Oro to form a loose, basilical complex. ${ }^{553}$ It was dedicated with the relics of saints, and it was designed as the tomb of the bishop who expected to be a martyr. In every way, it gave inspiration and impetus to the development of the martyrial chapels that were attached to churches across the span of Italy. But that was only part of the story. The relics of Gervasius and Protasius were widely translated; Augustine introduced them to Africa. ${ }^{554}$ Ambrose distributed them in northern Italy, and may have been responsible for taking them to Gaul at the time of his second mission to Maximus. ${ }^{555}$ In the sixth

\footnotetext{
${ }^{549}$ See above, Chapter II, Ambrose of Milan.

${ }^{550}$ Edwards (Lewis), "Two Critical Aspects of Fourth-Century Architecture at Milan," 93.

${ }^{551}$ Edwards (Lewis), "Two Critical Aspects of Fourth-Century Architecture at Milan," 94.

${ }^{552}$ Edwards (Lewis), "Two Critical Aspects of Fourth-Century Architecture at Milan," 93.

${ }^{553}$ As noted above, the chapel is now attached to the basilica, joined by an additional "sacred space" dedicated to St. Satyrus.

${ }_{554}$ Dudden, St. Ambrose, 304.

${ }^{555}$ Dudden, St. Ambrose, 304.
} 
century, relics of the saints were so numerous that Gregory of Tours felt compelled to tell a story to explain their prevalence. ${ }^{556}$

\section{The Basilica Apostolorum}

In 1946, a large-scale restoration of the church of S. Nazaro was begun to repair damage done during World War II. Although literary evidence linking the Basilica Apostolorum with the eleventh century Romanesque building had long been available, ${ }^{557}$ the restoration revealed that the documentary evidence was confirmed. In the excavations that followed, the foundations of the church were discovered, as well as portions of the fourth century fabric of the elevation that had been incorporated into the walls of the later church. ${ }^{558}$

Begun shortly after the Ambrosiana, during the period of Ambrose's halcyon days as the Christian mentor of the Emperor Gratian, ${ }^{559}$ Ambrose's choice of site for the church literally trumpets his confidence. Although it was located in a cemetery, the tombs which surrounded the church were non-Christian. Tomb fragments found in the excavation of the cemetery included only a single Christian burial, dated to $401,{ }^{560}$ and

\footnotetext{
${ }^{556}$ Dudden, St. Ambrose, 305. Gregory says that he 'heard' this story, and it is not found in any documents relating to the saints. Supposedly, during the Mass of the translation at the Ambrosiana, a panel fell from the ceiling and grazed the martyrs' heads, from which blood began to flow. Linen cloths were brought to soak up the blood; the fragments of those cloths were then distributed as brandea. The pervasiveness of the spread of the cult of Gervasius and Protasius in Gaul may be found in the number of churches dedicated to St. Gervase in France, and in the popularity of the name "Gervase." When one considers that there is not even a fragment of contemporary literature to document the identity or the martyrdom of these saints, the scope of their cult truly merits the epithet mind-boggling, and can only be explained by its close association with Ambrose of Milan.

${ }^{557}$ Suzanne Lewis, "Function and Symbolic Form," 83: In addition to Ambrose's letters and the biography of Paulinus, the medieval chronicler Landulphus Senioris, writing in his Historiae Mediolanensis, i. 6, gave a complete description of the building, noting its site on the Via Romana and its association with S. Nazaro. ${ }_{558}^{550}$ Lewis, "Function and Symbolic Form," 83.

${ }^{559}$ McLynn, Ambrose of Milan, 80. McLynn argues that Ambrose's relationship with Gratian was never as intimate nor as influential as has developed in the scholarship, and that Gratian's religious shift from his father's (Valentinian I) religious indifference reflected the pragmatic political realities of the day. Nevertheless, Ambrose composed five books on de fide for Gratian's edification, including De sacramentis and De mysteriis.

${ }^{560}$ Suzanne Lewis, "Function and Symbolic Form," 92.
} 
the building of the church would have displaced many graves. Clearly, Ambrose was not particularly concerned about the fate of Christian burials here, nor were there any sanctified graves such as were present in the Coemeterium ad Martyres; this was not to be a cemetery church.

Ambrose placed his church directly beside the Via Romana, which was the adventus route of the city, the road of ceremonial entrance for the emperors and all important dignitaries. The road, which was lined by a colonnade for six hundred meters

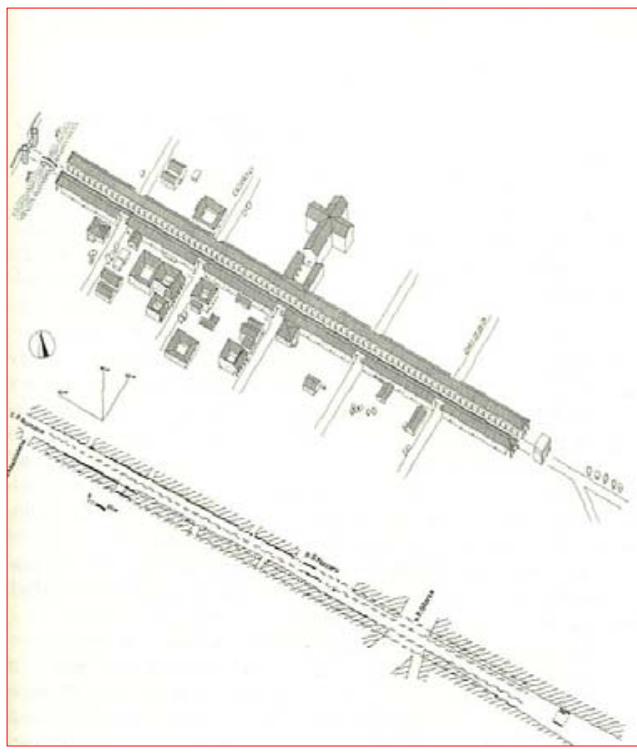

Figure 53: Milan: Location of B. Apostolorum on the Via Romana

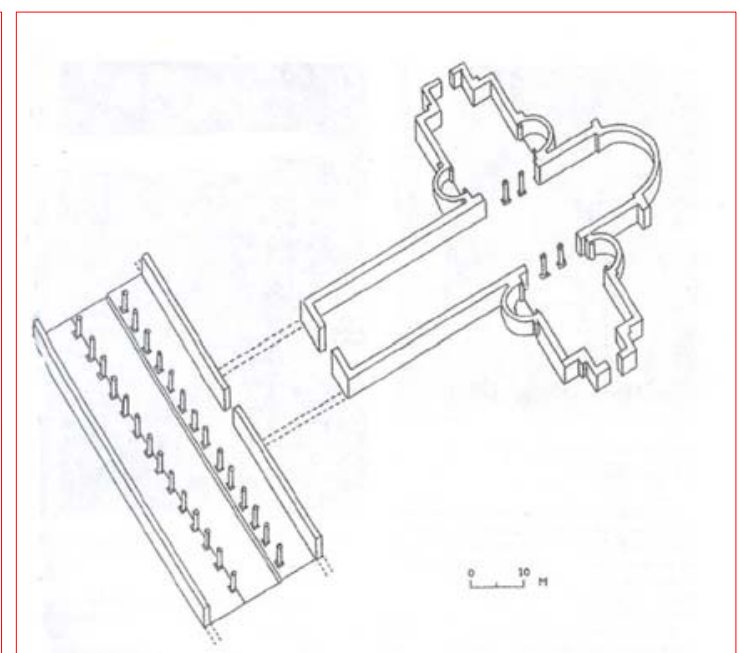

Figure 54: Milan: isometric reconstruction of the B. Apostolorum, showing segment of the propylaeum of the Via Romana

beyond the

gate, culminated in a triumphal arch. ${ }^{561}$ The (relatively small) atrium of Ambrose's church abutted the Via Romana, and would have incorporated the colonnade of the street, although

${ }^{561}$ McLynn, Ambrose of Milan, 232.

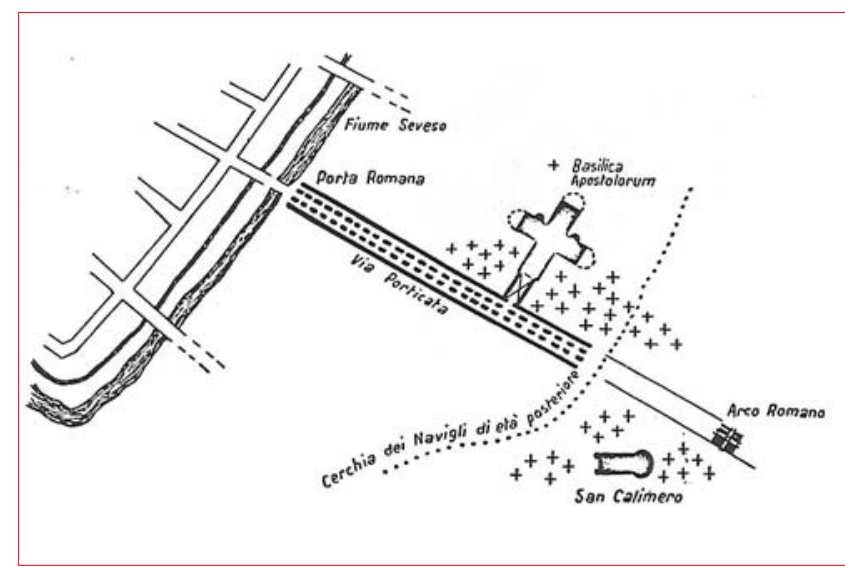

Figure 55: Milan: B. Apostolorum, topographical context 
there is no evidence that it crossed into the street. In this manner, Ambrose linked the basilica to the ceremonial activities of the city, and symbolically added a Christian element to the ceremony of adventus.

Not only was the location of the church striking (presumptuous?), but Ambrose chose a plan that was both exciting and radical. With the hindsight of fifteen hundred years of single-naved, cruciform churches in our vision, it is difficult to convey just how extraordinary Ambrose's design for this church was. Krautheimer has definitively shown that the B. Apostolorum was designed as a copy ${ }^{562}$ of the Church of the Apostles in Constantinople. ${ }^{563}$ Here Constantine had built the church where he wished to be buried, his sarcophagus placed prominently beneath the central dome, flanked by piers inscribed to the Twelve Apostles. Constantine, in designing a martyrial structure that focused on

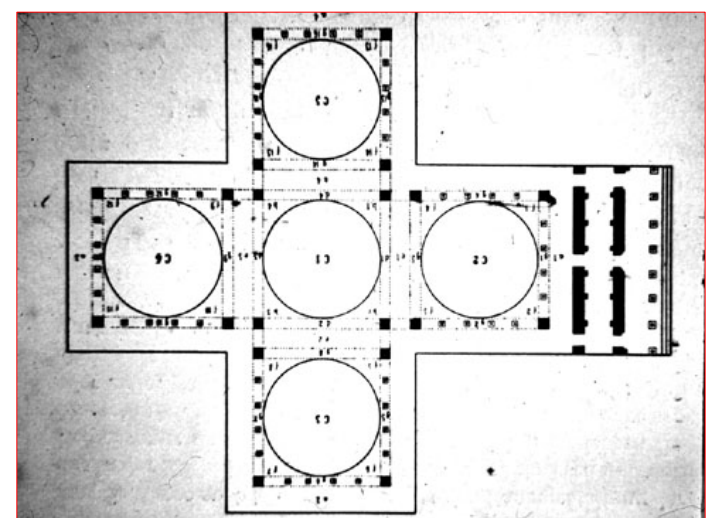

Figure 56: Constantinople: Plan of the Church of the Apostles (330)

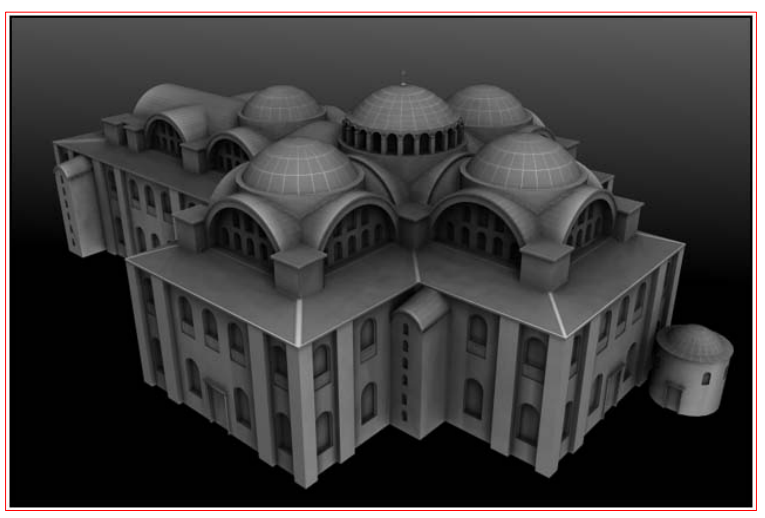

Figure 57: Constantinople: Isometric reconstruction of the Church of the Apostles

himself at the core of the cross, within a church where the Eucharist was offered at a nearby altar, ${ }^{564}$ had liturgically apotheosized himself as the Thirteenth Apostle. In 356/7 real relics of the Apostles were brought to the church, and the emperor's sarcophagus was

\footnotetext{
${ }^{562}$ For the medieval concept of a copy, which required only a mental identification with a single element of the original, see Krautheimer's seminal essay, "Introduction of an Iconography," 1-33.

${ }^{563}$ Krautheimer, Early Christian and Byzantine Architecture, 82.

${ }^{564}$ Krautheimer, Early Christian and Byzantine Architecture, 69.
} 
moved to a nearby, separate mausoleum of conventional Roman design, ${ }^{565}$ but the concept of the martyrial church, dedicated to the veneration of the martyrs and saints, remained, in the core of the crossed arms of the cruciform structure.

Ambrose's basilica was the first cruciform church built in the West, ${ }^{566}$ and although the design became a cliché through the centuries, in the fourth century it was still very rare, even in the East. After the Church of the Apostles, the earliest example (ca. 379) is the martyrium church of St. Babylas in Antioch-Kaoussié.

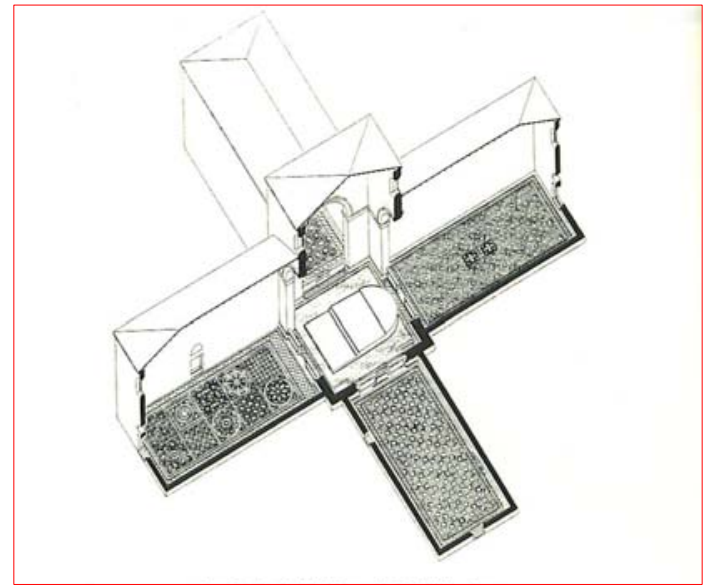

Figure 58: Antioch-Kaoussié: Isometric reconstruction of St. Babylas

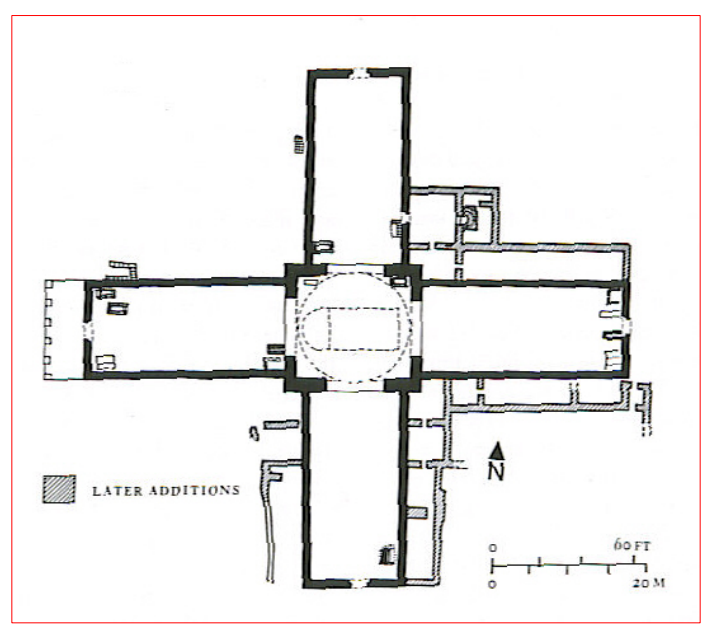

Figure 59: Antioch-Koussieé, Plan of St. Babylas

Ambrose's decision to use a cruciform plan for his church must be accepted as complex symbolically. Iconographically, the use of the cross as a symbol of Christ's sacrifice to redeem mankind is anachronistic to a later age. In the late fourth century, the cross was seen as a symbol of Christ's victory over death, analogized to the triumph of the Christian faith over paganism and heresy. ${ }^{567}$ In 379 and 380 both the Augusti, Gratian

\footnotetext{
${ }^{565}$ See page 162.

${ }^{566}$ Lewis, "The Latin Iconography," 205.

${ }^{567}$ Lewis, "The Latin Iconography," 207.
} 
and Theodosius issued anti-Arian edicts. ${ }^{568}$ Ambrose celebrated his victory at the Council of Aquileia over the anti-Nicene bishops in 381, and in 382, Gratian ordered the altar of Victory to be removed from the Senate in Rome. In siting his church on the adventus route of Milan, and in choosing the radical plan of the cross, the first layer of Ambrose's motivation must be accepted as the triumph of orthodoxy over paganism and heresy.

Gino Chierici (1946) has determined that the original structural aspect of the church was a single-naved basilica, $56 \mathrm{~m}$. long from the vertex of the apse to the west façade, $14.20 \mathrm{~m}$. wide. The apse, which was introduced by a massive triumphal arch, was exactly the same width as the nave, probably vaulted with timber vaulting; ${ }^{569}$ the ceiling also was a timbered roof. The longitudinal nave was crossed by transverse arms of the same width as the nave, the axis of which crossed the nave $14.20 \mathrm{~m}$. from the chord of the apse; the length of the crossing structure was $63.60 \mathrm{~m}$. long; each of the arms which formed on either side of the nave was $18.55 \mathrm{~m}$. long. The arms were introduced by massive triumphal arches (see below) which thereby defined the central square of the sanctuary of the altar, $14.12 \mathrm{~m}$. by $12.25 \mathrm{~m}$; ; these were arcaded with a triple set of smaller arches. Capitani d'Arzago has proposed that this central square was also vaulted, ${ }^{570}$ but subsequent excavation has not substantiated this hypothesis. The original arms of the church were terminated by rectangular niches, the purposes of which pose something of a problem. Villa has suggested that they included doors and functioned as

${ }^{568}$ Lewis, "The Latin Iconography," 207. Gratian issued the edict Omnes vetitiae (Codex Theodosiani 16. 5. 5), which abrogated the degrees of tolerance of the Council of Sirmium, and several months later Theodosius issued a similar edict at Thessalonika (Codex Theodosiani 16. 1. 12).

${ }^{569}$ Edwards (Lewis), "Two Critical Aspects of Fourth-Century Architecture at Milan," 137. The apse was vaulted with a half-domical vault in the $11^{\text {th }}$ century renovation, which made it shallower than the original apse.

${ }^{570}$ Edwards (Lewis), "Two Critical Aspects of Fourth-Century Architecture at Milan,” 140. 
vestibules ${ }^{571}$ which would tend to reinforce the transverse axis of the lateral arms which was punctuated by the intercolumniation of the arcades of the crossing arches. However, the niches could just as easily have served a liturgical purpose and been introduced by windows. There is no archeological evidence of the presence of doors. ${ }^{572}$ Each of the arms possessed a pair of exedrae which formed small apses on the east and west walls of the arms, close to the north and south walls of the nave; these apses were also timbervaulted.

The foundations of the church are consonant with the late Roman foundations of S. Tecla, i.e. trench-cast concrete with an aggregate of river pebbles, brick fragments, tiles and other re-used material in a mixture of sand and lime mortar. The thickness of the foundations under the perimeter walls maintained an average of $1.32 \mathrm{~m}$. The original pavement of the church was opus sectile and was slightly lower than the present pavement. As noted above in the introduction to this chapter, the brick masonry of the walls showed the characteristic opus spicatum which is displayed by all of the Ambrosian churches. The raw masonry walls, which present a consistent measurement of $78 \mathrm{~cm}$, were probably plastered and painted and the lower sections of the walls may have been reveted with marble panels. ${ }^{573}$ There is no trace of the original windows, although Villa has suggested that the size of some of the Romanesque windows, which are unusually large, may have originally been the Early Christian windows. ${ }^{574}$

With the siting of the church on the colonnaded street, there is a consensus that the church was introduced by a rectangular atrium of the same width as the longitudinal

\footnotetext{
${ }^{571}$ Edwards (Lewis), "Two Critical Aspects of Fourth-Century Architecture at Milan," 141.

${ }^{572}$ Edwards (Lewis), "Two Critical Aspects of Fourth-Century Architecture at Milan," 141.

${ }^{573}$ Edwards (Lewis), "Two Critical Aspects of Fourth-Century Architecture at Milan," 139.

${ }^{574}$ Edwards (Lewis), "Two Critical Aspects of Fourth-Century Architecture at Milan," 139.
} 
nave, but no archeological remains have been found that would support this supposition. ${ }^{575}$ However, it is possible that the church did have an additional structure adjoining the west façade immediately preceding the nave. This structure, which is obscured by the sixteenth century mausoleum of Giacomo Trivulzio (designed by Bramante), was eight-sided with semicircular niches at the four corners; its Early Christian foundations were apparently incorporated into Bramante's plan for the mausoleum. Although the octagonal footprint suggests a baptistery, its peculiar location seems to rule out that function. It is possible that it also served as a martyrial chapel, perhaps an extant mausoleum that was left in place as the Chapel of S. Vittore in Ciel d'Oro was left in place at the Ambrosiana. It may also have served a liturgical function, perhaps in the development of the more Eastern aspects of the Offertory. It could also have functioned as a sacristy, or alternatively as a treasury. Without contemporary documentation, there is no way of knowing to the original purpose of the building.

We have the inscription of the church to point us to the next layer of motivation behind the choice of this symbolically loaded basilical plan:

Condidit Ambrosius templum Dominoque sacravit Nominee apostolico, munere, reliquiis. Forma crucis templum est, templum Victoria Christi Sacra triumphalis signat imago locum. ${ }^{576}$

\footnotetext{
${ }^{575}$ Edwards (Lewis), “Two Critical Aspects of Fourth-Century Architecture at Milan,” 143.

${ }^{576}$ Lewis, "The Latin Iconography," 205: "Ambrose built a temple for the Lord and consecrated it in the name of the Apostles with a gift of relics. The temple is in the form of a cross...a triumphal image [which] marks the place with the sacred victory of Christ." The authenticity of the inscription was verified in 1947 with the finding of two marble fragments of the original inscription which is recorded in the $5^{\text {th }}$ century collection of extracts of ancient Milanese marbles, the Sylloge Laureshamensis: Circumpadana et Cisalpina, Cod. Vat. Pal. 833, in Corpus Inscriptionum Latinarum, v, No. 3, 617. Since the rest of the inscription refers to deposition of the relics of St. Nazarius (see below), it must be assumed that it was created after 396/7 when the relics were translated to the church.
} 
Like the Apostoleion in Constantinople, Ambrose received treasured relics of the Apostles Peter and Paul from Pope Damasus for the consecration of his church, ${ }^{577}$ sometime prior to June of 386 when he dedicated the B. Martyrum. In 1568, Bishop St. Charles Borromeo disinterred the silver reliquary casket from beneath the altar and had it opened. The authentication of the casket's antiquity was established by the translation of some inscriptions written in a late Roman cursive script. ${ }^{578}$ On the lid is inscribed a representation of Christ flanked by two figures whose iconography is consonant with the Late Antique representations of Peter and Paul. ${ }^{579}$ The relics appear to have been bits of cloth and were re-interred after the examination. However, these were not the only relics that were translated to the Apostolorum. The Martyrologium Hieronymianum records the ingressus of the relics of Saints John, Andrew and Thomas on the ninth of May; ${ }^{580}$ McLynn suggests that the basilica may have been dedicated on that day, and that these relics may have been the gift of Theodosius. ${ }^{581}$ A later commemoration (27 November) is noted with the additional gift of the relics of Luke and the Chalcedonian martyr Euphemia (included in the Ambrosian Litany of the Saints). ${ }^{582}$ Eventually, the church accommodated the martyr St. Nazarius as well (another dramatic discovery by Ambrose in a garden outside the city, 395-396). ${ }^{583}$ So, the next layer of purpose for this church must have been entwined in its martyrial function and the bishop of Milan's embrace of

\footnotetext{
${ }^{577}$ Dudden, St. Ambrose, 299 according to Paulinus, Vita Ambrosii, 33. Damasus vigorously promoted the cult of Peter and Paul for the same reason that Ambrose promoted the cult of the martyrs Gervasius and Protasius: to extend the hegemony of the see through the patronage of relics.

${ }_{578}^{578}$ McLnn, Ambrose of Milan, 231.

${ }^{579}$ McLynn, Ambrose of Milan, 231. See note 735 for this description.

${ }^{580}$ McLynn, Ambrose of Milan, 230.

${ }^{581}$ McLynn, Ambrose of Milan, 230. The Eastern provenance in the Apostoleion of these saints suggests that the gift may have come from the emperor.

${ }^{582}$ This may possibly account for her inclusion in the Ambrosian Litany.

${ }^{583}$ Lewis, "Function and Symbolic Form," 93.
} 
the cult of the saints, which received such fervent reinforcement in the dedication of B. Martyrum.

Even so, both the size of the church and its location indicate that this basilica was also designed to serve a congregational purpose, a justification that Ambrose used. ${ }^{584}$ From that aspect, we must accept that the church may have been specifically designed to accommodate certain elements of the Ambrosian liturgy, in its usage as a congregational church. Unlike the martyrium of St. Babylas, where the equal arms of the Greek cross design converge with a central focus on the tomb of the saint, the extension of the eastwest axis of the Latin cross design of the B. Apostolorum disturbs that focus. The spatial elements of the long, longitudinal nave negate the centralizing authority of the transverse arms. As Lewis notes, "In this Ambrosian structure...even the most fundamental distinction between martyrium and Eucharistic hall has become blurred." 585

We can understand this more clearly when we consider how Ambrose disposed the relics that were brought into the church.

In both the B. Apostolorum and the Ambrosiana, Ambrose interred the relics beneath the altar. This in itself was an innovation. The consecration of an altar with relics did not become a papal requirement until the ninth century; from the sixth century until the ninth century relics

\footnotetext{
${ }^{584}$ Noted in the section on the B. Martyrum above.

${ }^{585}$ Lewis, "Function and Symbolic Form," 85.
}

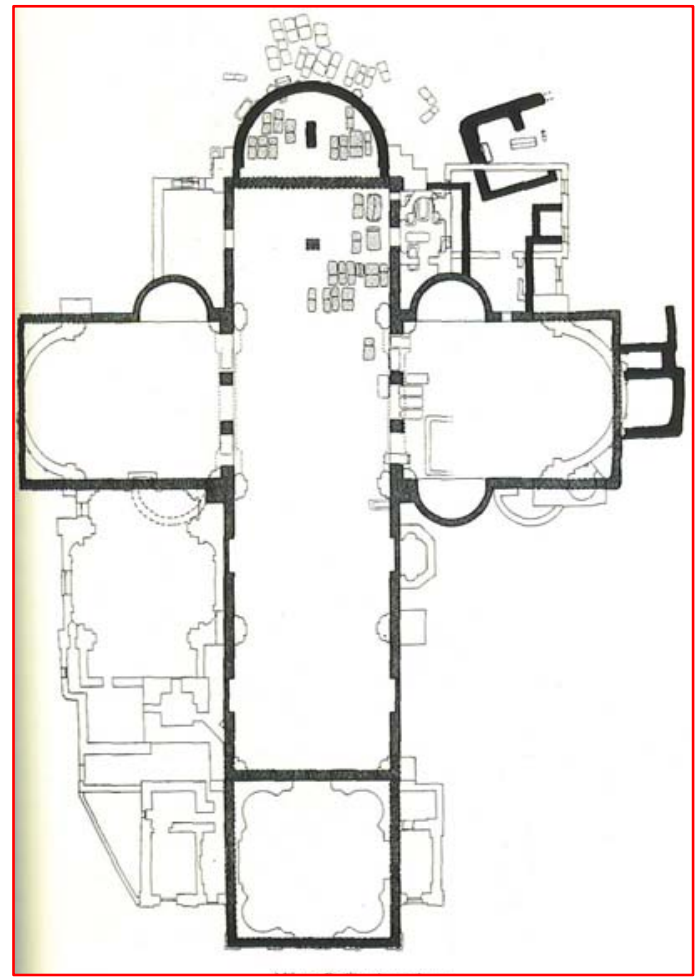

Figure 60: Milan, B. Apostolorum (386) 
were normally placed on the altar for their reception in the church and then moved to a designated sacred space. ${ }^{586}$ By interring the relics beneath the altar, Ambrose linked the Passion of Christ, through the witness of the Apostles and martyrs, to the liturgical celebration of the Eucharist. Far from being mere objects of veneration, they now served to dramatize the liturgy. Since the lateral halls of the transverse arms had no function as sacred space for the disposition of the relics, they too must have served a liturgical function. With the nave reserved for the processions and the liturgical action of the clergy, these halls must have functioned as the aisles of the hypostyle basilica functioned, as the space designated for the congregation.

One of the most important discoveries in the restoration of S. Nazaro was that the

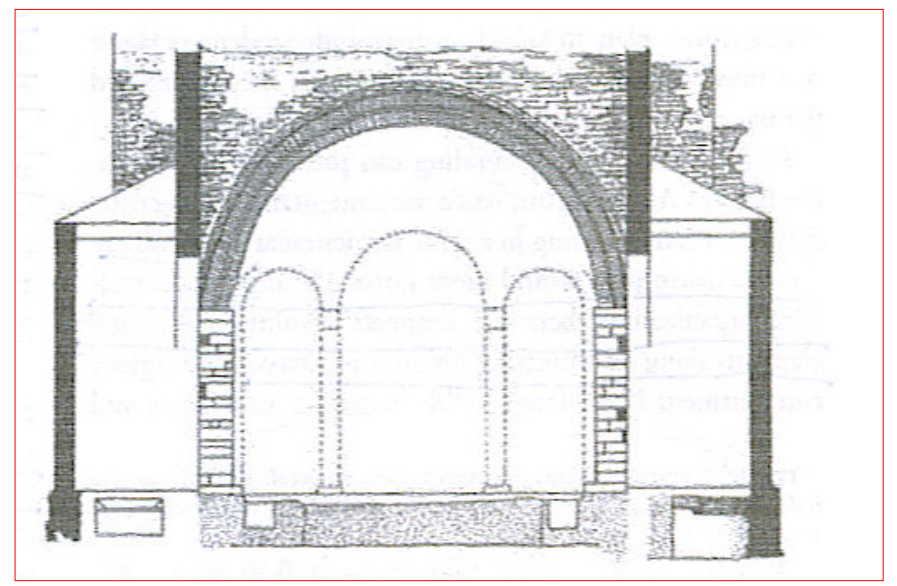

Figure 61: Milan: B. Apostolorum, reconstruction of the triple arcade of the transverse arch two fourth century arches that form the crossing of the transverse halls, as well as the four piers that support the arches, belonged to the original church and were left in place by the Romanesque builders. The arches, $12.25 \mathrm{~m}$. wide in span with two concentric rings of radiating bricks, were framed by a double crown of smaller bricks laid tangent to the extrados of the arch. A contiguous arch, grafted within the great arch, provided a triple arcade that separated the halls from the nave. With the altar forming the fulcrum of the church at the crossing, the congregation would have had a clear view of the Eucharistic

${ }^{586}$ Dudden, St. Ambrose, 302. 
celebration, as well as access to the altar in the disposition of their gifts during the Offertory.

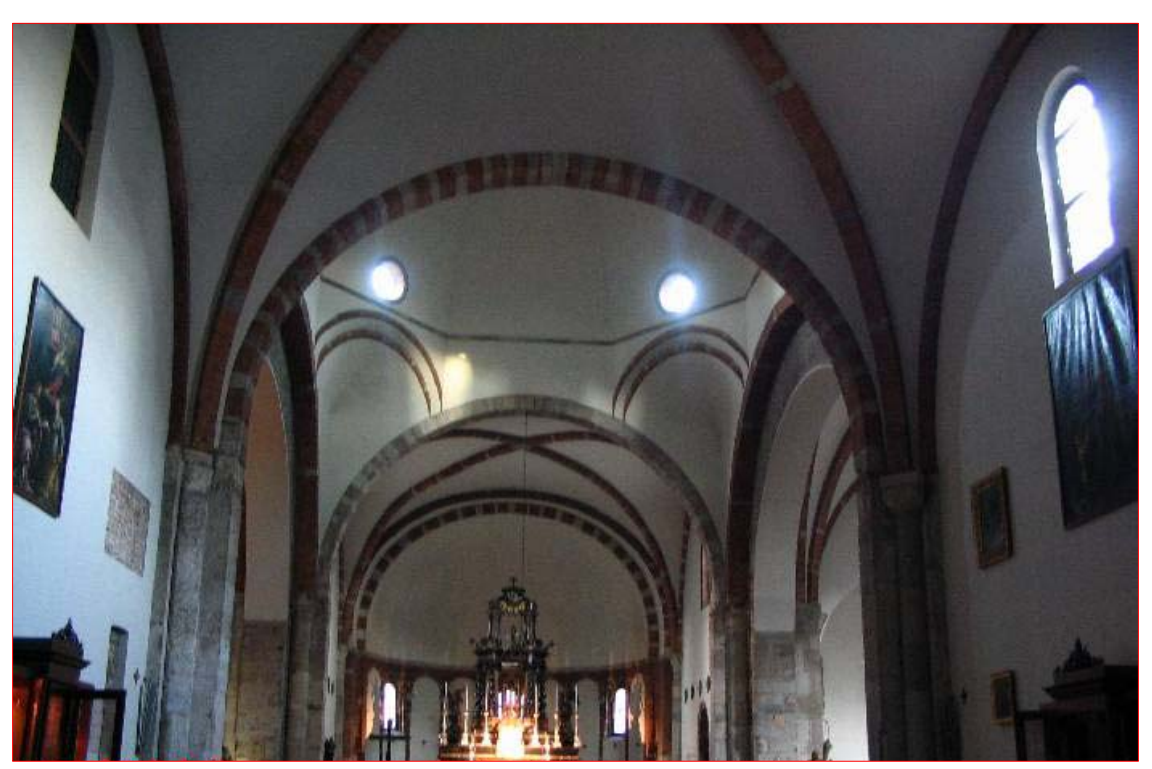

The addition of the small exedrae shown on the plan is a further indication that the transverse halls were

Figure 62: Milan: S. Nazaro, nave and transverse arches designated as congregationalspace. These niches, which are part of the original fourth century structure, have been shown to have functioned as sepulchral chapels, at least by the fifth century. A stone inscription and a sarcophagus discovered beneath the west exedra of the south hall identified it as belonging to a doctor named Dioscouros, and the episcopal Catalogues of Milan indicate that at least four fifth-century bishops are buried in the B. Apostolorum. $^{587}$ This would suggest that the transverse halls were intended to accommodate the burial of bishops and prominent laymen ad sanctos, near the altar, with the added advantage that the graves would be accessible to the congregation, but safe from treading (a problem faced by burials in the traditional hypostyle basilica).

We therefore have a clear picture of a church designed to facilitate the liturgy functionally. The long, aulic nave was reserved for the procession of the clergy with the altar anchoring the liturgy. Behind the altar, the apse and the space of the presbytery

\footnotetext{
${ }^{587}$ Lewis, "Function and Symbolic Form," 95.
} 
were reserved for the clergy, as in traditional basilicas. The congregation was contained in the north and south halls of the transverse crossing, from which they could process with their gifts to the altar and to communion. The altar was consecrated with relics, symbolically linking the Eucharist to its institution by Christ. Far from being the gigantic martyrium as it was characterized by André Grabar, ${ }^{588}$ the Basilica Apostolorum represented a specific attempt to integrate the liturgy and its action with the design of the church. This constituted a quantum leap in the West from the original appropriation of the Roman basilica as a Christian congregational venue.

Nevertheless, it was not entirely successful. With the congregation contained within the arms of the church, their view of the procession of the clergy would have been restricted to the clergy's approach to the sanctuary and the presbyterium. Additionally, we are hard-pressed to visualize the orderly movement of the clerical complement which would have facilitated the processions. And, from a purely practical standpoint, the long expanse of the nave is wasted space when it is not being used for procession.

The awkwardness of the transverse halls was further revealed with the installation of the relics of St. Nazarius ten years later, at which time an additional altar was placed into the apse. Two documentary sources support the deposition of St. Nazarius in the apse of the church. The first is the continuation of Condidit Ambrosius:

In capite est templi vitae Nazarius almae et sublime solum martyrii exuviis, Crux ubi sacratum caput extulit orbe reflexo Hoc caput est templo, Nazarioque domus. Qui fovet aeternam victor pietate quietem, Crux cui palm fuit, crux etiam sinus est. ${ }^{589}$

\footnotetext{
${ }^{588}$ André Grabar, Marrtyrium: Recherches sur le culte des reliques et l'art chrétien antique, I (Architecture) (London: Varorum Reprints, 1972), 425-426.

${ }^{589}$ Lewis, "Function and Symbolic Form," 97: "At the head of the temple where the floor is raised, Nazarius of the innocent life rests in the bones of the martyr. The cross consecrated where the head is
} 
Again, the theme of victory is stressed in the design of the church as a symbolic re-enactment of the victory of the martyr whose location is clearly indicated at the head of the church in the retreating circle of the apse.

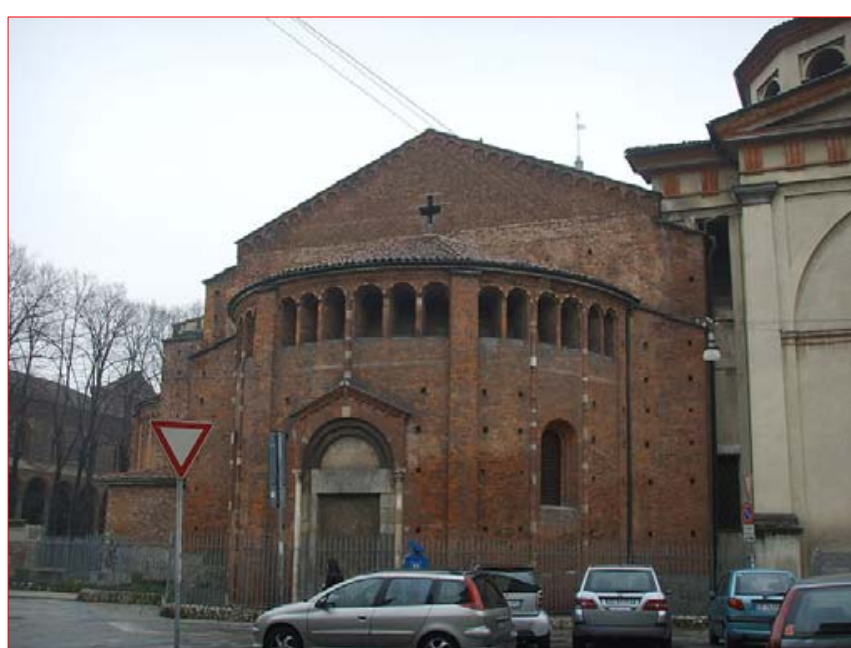

Figure 63: Milan: S. Nazaro, east facade

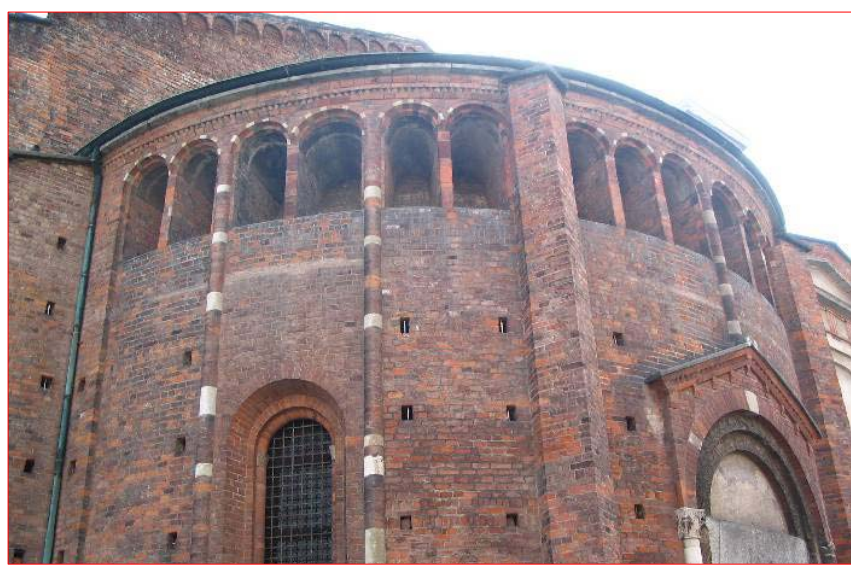

Fiaure 64: Milan: S. Nazaro. exedra of the west lateral
The second documentary

source is the epitaph (402-404) of

Serena, the wife of Honorius'

general Stilicho, who donated a

piece of costly Libyan marble to

adorn the place where St. Nazarius

had been interred. This epitaph also

refers to the apse as the locus of the

martyr. ${ }^{590}$ As such, it appears that

the martyrial function was restored

to the church, with a designated

sacred space for the veneration of the

saint. ${ }^{591}$ But the inherent difficulties

raised in a retreating circle, this head is in the temple and [is] the house of Nazarius. He who cherishes eternal piety [and] repose [is] the victor to whom the cross was the palm [of victory], [because] the bending curve is still the cross."

${ }^{590}$ Lewis, "Function and Symbolic Form," 97: Qua sinuata cavo consurgunt tecta regressu sacrataque crucis flectitur orbe caput, Nazarius vitae immaculabilis integer artus conditur; exultat hune tumuli esse locum; quem pius Ambrosius signavit imagine Christi marmoribus Libycis fida Serena polit; coniugia ut reditu Stiliconis laeta fruatur, Germanisque suis pignoribus propriis (Where curved, consecrated coverings, stepped back, rise up over a cavity and the head of the cross bends in a circle, Nazarius of the immaculate life makes limbs whole; he exults that tombs be placed there; that which holy Ambrose signified in the image of Christ, faithful Serena embellished with Libyan marble; wife of Stilicho the German, she was glad to offer [these] riches as lasting pledges of her love.).

${ }^{591}$ Lewis, "Function and Symbolic Form," 95. As late as the $16^{\text {th }}$ century, S. Nazaro had two altars: the altar at the crossing was dedicated to St. Peter, the other, in the apse, to St. Nazarius. 
associated with the plan remained, such that the Romanesque reconstruction of the church removed the central altar, leaving the altar of St. Nazarius in the apse as the high altar. The construction of the Basilica Virginum would address these flaws.

\section{The Basilica Virginum}

The largest of Ambrose's churches, the Basilica Virginum, has been periodically excavated since 1813 , but it was not until the extensive excavations of the 1940s were

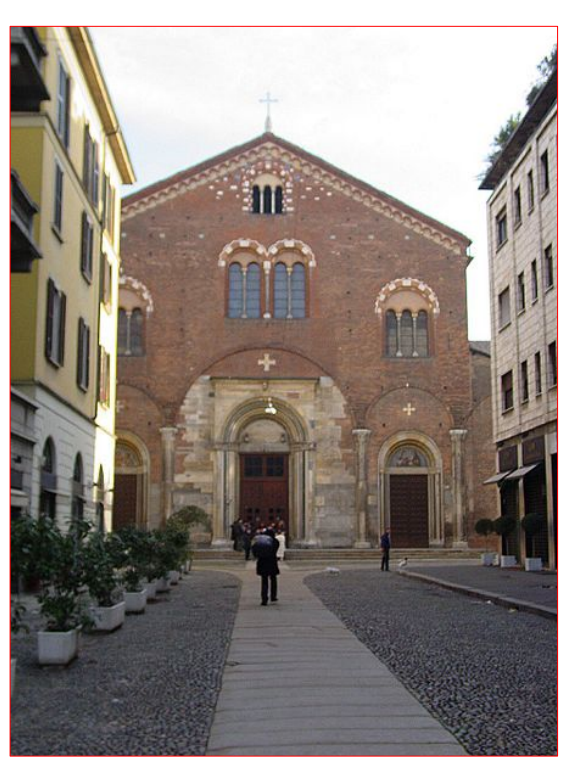

Figure 65: Milan: S. Simpliciano, west façade

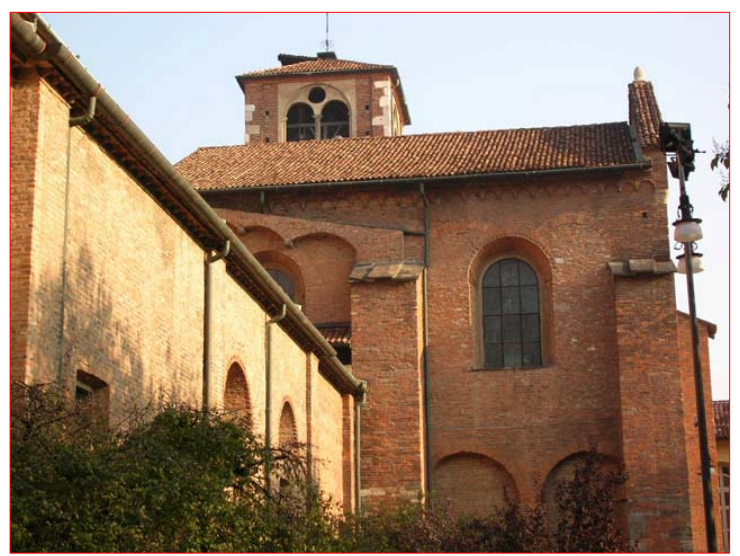

Figure 67: Milan, S. Simpliciano, north façade done $^{592}$ that the fourth century basilica was revealed to have been incorporated into the twelfth century church known as S. Simpliciano. The Romanesque church included not only the foundations, but large tracts of the elevation, rising to $20 \mathrm{~m}$. above the level of the present pavement, which had been incorporated into the later church's walls. ${ }^{593}$ The massiveness of the church, which originally encompassed more than 2000 sq. $\mathrm{m}$, would have rivaled the size of the cathedral of
Nave: $70 \mathrm{~m}$. long by $21.7 \mathrm{~m}$. wide

Transverse Hall: $57 \mathrm{~m}$. (total length) by $17 \mathrm{~m}$. wide

Projection of the Transverse Halls from the north and south wall: $17 \mathrm{~m}$.

Figure 66: Dimensions of S. Simpliciano

\footnotetext{
592 Edwards (Lewis), “Two Critical Aspects of Fourth-Century Architecture at Milan,” 194, by Arslan.

${ }^{593}$ Edwards (Lewis), "Two Critical Aspects of Fourth-Century Architecture at Milan,” 195.
} 
Tecla, able to serve a congregation of more than three thousand. ${ }^{594}$ Fortunately, the extraordinary preservation of much of the fourth century fabric of the church has given insight into the construction of all the Ambrosian foundations.

During the excavations, the arches of ten early Christian windows were revealed by removing the interior plaster. The arrangement of the masonry matches the masonry of the transverse arches of S. Nazaro, concentric rings of brick with the outer ring laid tangent to the extrados of the arches. These windows were extremely large $(4.80 \mathrm{~m}$. high by $2.15 \mathrm{~m}$. wide with an interval of $1.90 \mathrm{~m}$.); ${ }^{595}$ and, ranging along the north and south flanks of the church, they must have admitted a significant amount of light. Additionally, the excavations have revealed that the Romanesque arcade on the lower order is a reconstruction of the fourth century arcade. As such, today's S. Simpliciano's structure is little different from its fourth century appearance.

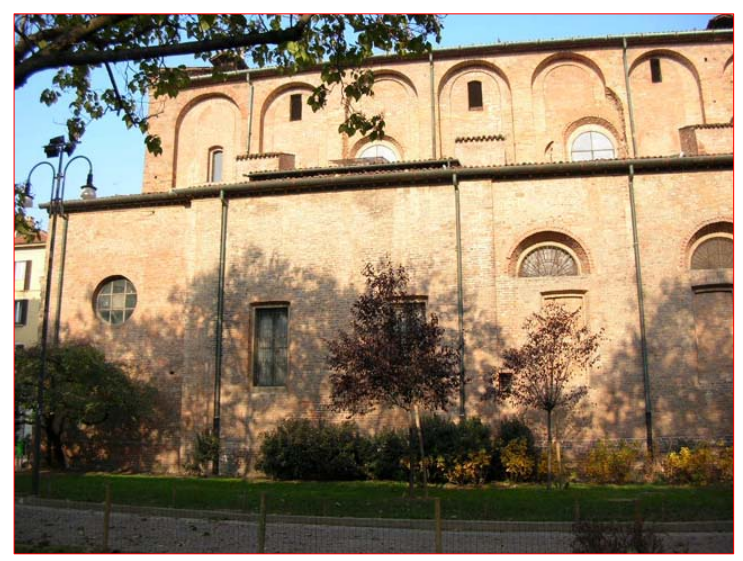

Figure 68: Milan: S. Simpliciano, south façade
In its masonry as well, we see the pattern of herringbone brickwork that has characterized all the Ambrosian foundations. The masonry, however, is much finer work, rivaling S. Tecla's, which indicates that the funding challenge had improved in the intervening years between the building of

\footnotetext{
${ }^{594}$ Edwards (Lewis), "Two Critical Aspects of Fourth-Century Architecture at Milan," 195.

${ }^{595}$ Edwards (Lewis), "Two Critical Aspects of Fourth-Century Architecture at Milan," 196.

${ }^{595}$ Edwards (Lewis), "Two Critical Aspects of Fourth-Century Architecture at Milan," 196.
} 
explain why the fineness of the brickwork that so disturbed Krautheimer in the Baptistery of S. Giovanni alle Fonti ${ }^{596}$ may indeed have been achieved under Ambrose's aegis. The entire building was articulated by blind arcades on the exterior, possibly a double arcade, which was surmounted by the row of windows; it is clear that great care was taken with this building.

The building was originally dedicated to the Virgin and all the virgin saints. It might be argued that this dedication in advance of the Council of Ephesus (431), which affirmed the Virgin as the Theotokos, was anachronistic in anticipating the cult of the Virgin. But this is not so. Ambrose, with the example of his sister's early espousal of perpetual virginity, had a special devotion to and exaltation of virginity. The number of treatises that he wrote on the subject is sufficient testimony to his interest. ${ }^{597}$ Dudden notes that the mothers of Milan would "lock up their young daughters within doors that

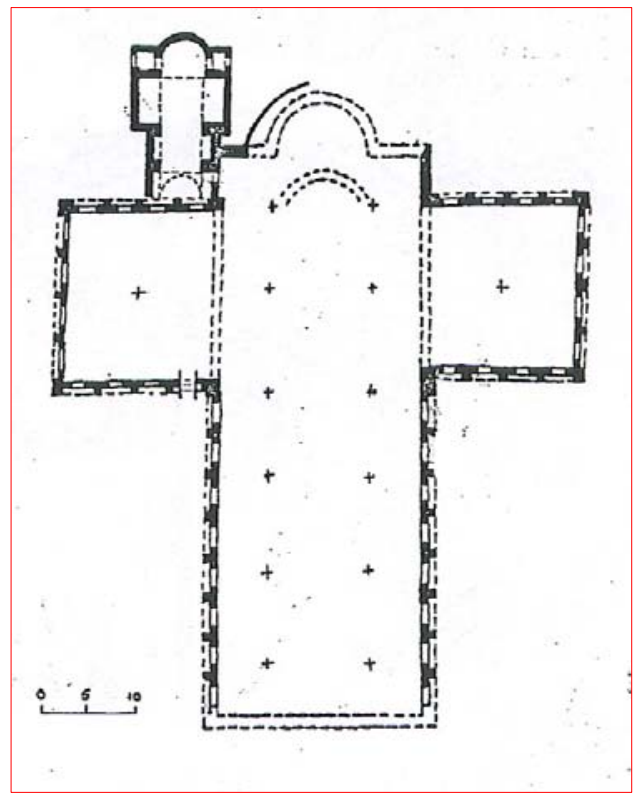

Figure 69: Milan: Plan of B. Virginum with cruciform oratory they might not fall under the spell of the bishop's eloquence in the cathedral."${ }^{.598}$

As can be seen from the plan, a small oratory was attached to the northeast corner of the church; although it has been identified as part of the original complex, it existed as a separate oratory in its original iteration with an interval of $2.75 \mathrm{~m}$. separating the two structures. ${ }^{599}$ While there is very little documentary evidence

\footnotetext{
${ }^{596}$ Krautheimer, Early Christian and Byzantine Architecture, 176.

${ }_{597}^{5 e}$ virginibus (377), De virginitate and De institutione virginis (392), Exhortatio virginitatis (393)

${ }^{598}$ Dudden, St. Ambrose, 148.

${ }^{599}$ Edwards (Lewis), "Two Critical Aspects of Fourth-Century Architecture at Milan,” 204.
} 
associated with the basilica, Paulinus notes that the relics of the Val di Non martyrs, Sisinnius, Martyrus, and Alexander, were conceded to Ambrose by Vigilius, the bishop of Trent, and were brought to Milan shortly after Ambrose's death in $397{ }^{600}$ Presumably, this small cruciform oratory was added as an appropriate resting place for the martyrs. ${ }^{601}$

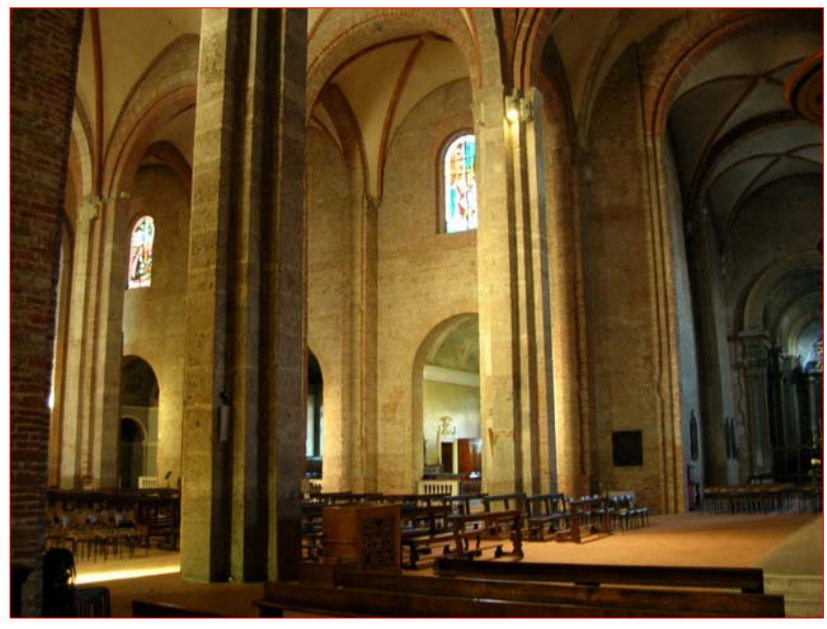

Figure 70: Milan: S. Simpliciano, interior showing the transverse crossing

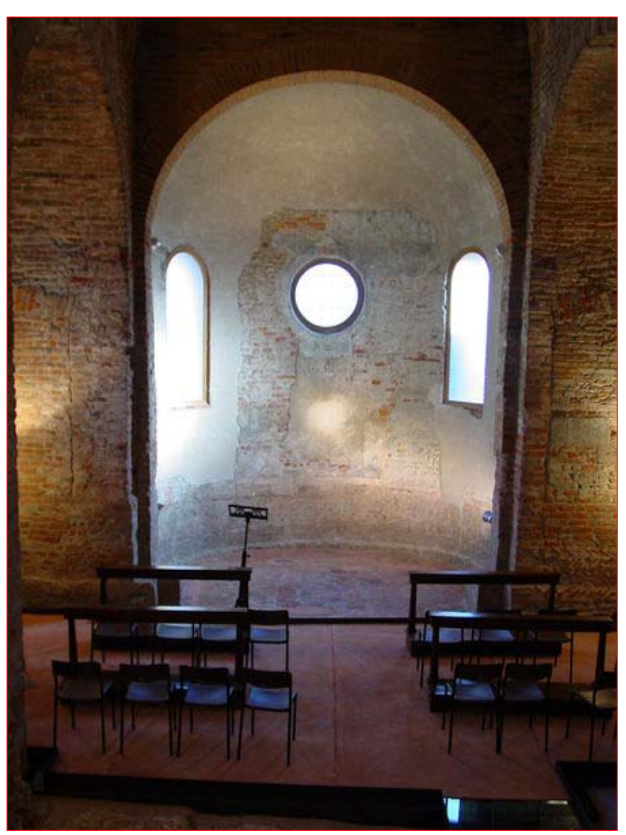

was planned as a congregational church. The cruciform plan, so innovative in the B.

Apostolorum, has been refined of its awkwardness to more easily accommodate the liturgy. The addition of aisles to the nave once again provided for the congregation within the body proper of the church. The transverse hall, while still symbolically representing Christ's

Figure 71: Milan: S. Simpliciano, oratory

\footnotetext{
${ }^{600}$ McLynn, Ambrose of Milan, 235.

${ }^{601}$ Edwards (Lewis), "Two Critical Aspects of Fourth-Century Architecture at Milan," 195.

${ }^{602}$ Edwards (Lewis), "Two Critical Aspects of Fourth-Century Architecture at Milan," 206.
} 
victory, has become an elongated transept. Unlike the B. Apostolorum and the Ambrosiana, the addition of the separate martyrial oratory separated the devotion to the cult of the saints from the main church. Although Bishop St. Simplicianus was eventually interred in the basilica, this does not appear to have happened prior to the eighth or ninth century, which is when the basilica was rededicated to him. ${ }^{603}$

In the Basilica Virginum we see the final iteration of the evolution of the Ambrosian foundations. The congregational church, dedicated to the victory of Christ over paganism and heresy, was epitomized in the single-naved, cruciform plan that would appear in various forms across the span of northern Italy in the fifth and sixth centuries and across Europe in the embodiment of the veneration of the cross as the ultimate expression of Christ's redemption of mankind. The relics of the martyrs and saints, ultimately used liturgically to consecrate altars and churches, were given sacred space in the addition of the accessory martyrial chapel that would also become a fixture. And finally, the church was designed to accommodate its liturgical functions of procession, chant and psalmody, Offertory, Eucharist, and communion of the faithful in a manner that promoted the stately and archaic Ambrosian liturgy.

However, all of these churches lacked one additional structure that would additionally proliferate across the span of the northern Italian corridor and extend to the whole of Italy. None of these churches had a baptistery. In Milan, in the time of Ambrose, only the bishop baptized, and the bishop baptized from the seat of his episcopal mandate: the cathedral.

\footnotetext{
${ }^{603}$ Edwards (Lewis), “Two Critical Aspects of Fourth-Century Architecture at Milan,” 210.
} 


\section{The Baptistery of S. Giovanni alle Fonti}

There is so little documentary evidence associated with the construction of the Baptistery of S. Giovanni alle Fonti, that were it not for the excavation of S. Tecla, first begun in 1943 and continued in the early 1960s, we might never have known that it existed. Ambrose mentions the existence of more than one baptistery once; in the letter written to his sister Marcellina concerning the occupation of the Portiana, Ambrose clearly states that he "...dismissed the catechumens and then went on giving an exposition of the Creed to several candidates for baptism in the baptistries of the basilica." ${ }^{604}$ The letter was written at Easter, 386, and is our principal source for the account of Ambrose's battle with the Dowager Empress Giustina in which he refused to allow any church, including the palatine church of the Portiana (S. Lorenzo), to be used by the anti-Nicenes. We also know that Augustine was baptized a year later, at the Easter vigil on April 24, 387, ${ }^{605}$ and that he was baptized in the old baptistery. ${ }^{606}$ Dudden speculates that, after the construction of the new baptistery, baptisms (which involved the candidates being stripped naked) were segregated according to sex between the baptisteries. ${ }^{607}$ Logistically, this seems a difficult proposition, with the bishop scurrying between buildings to duplicate the holy rites in the (already) lengthy service of the Easter Vigil. And, since the priests and deacons performed the anointings with oil, the modesty of the women would have been violated anyway. But it is possible, since Ambrose

\footnotetext{
${ }^{604}$ Ambrose, Epistolae, xx, 4. (My emphasis.) Dudden notes (St. Ambrose, 338) that the majority of manuscripts read, 'in baptisteriis ...basilicae' as opposed to 'in baptisterii...basilica.'

${ }^{605}$ Dudden, St. Ambrose, 342. Easter is a 'movable feast' of the Church, tied to the Jewish Passover, the lunar calendar, and the vernal equinox. The use by the Milanese of the Eastern calendar multiplies the difficulties associated with dating by Easter.

${ }^{606}$ See above, note 196.

${ }^{607}$ Dudden, St. Ambrose, 338.
} 
indicates that he was instructing in both baptisteries. The chronology of the newer baptistery will remain problematic.

The choice of the octagonal plan was not innovative. Krautheimer has already shown that the association of baptisteries with Roman mausolea inspired the structural plan for the small building, and Ambrose had a ready-made prototype within Milan from which to draw inspiration: an imperial mausoleum within the vicinity of the Coemeterium ad Martyres, near the basilica of S. Vittore al Corpo. The persistent mention in the medieval chronicles ${ }^{608}$ of a villa complex was verified by the discovery of the remains of

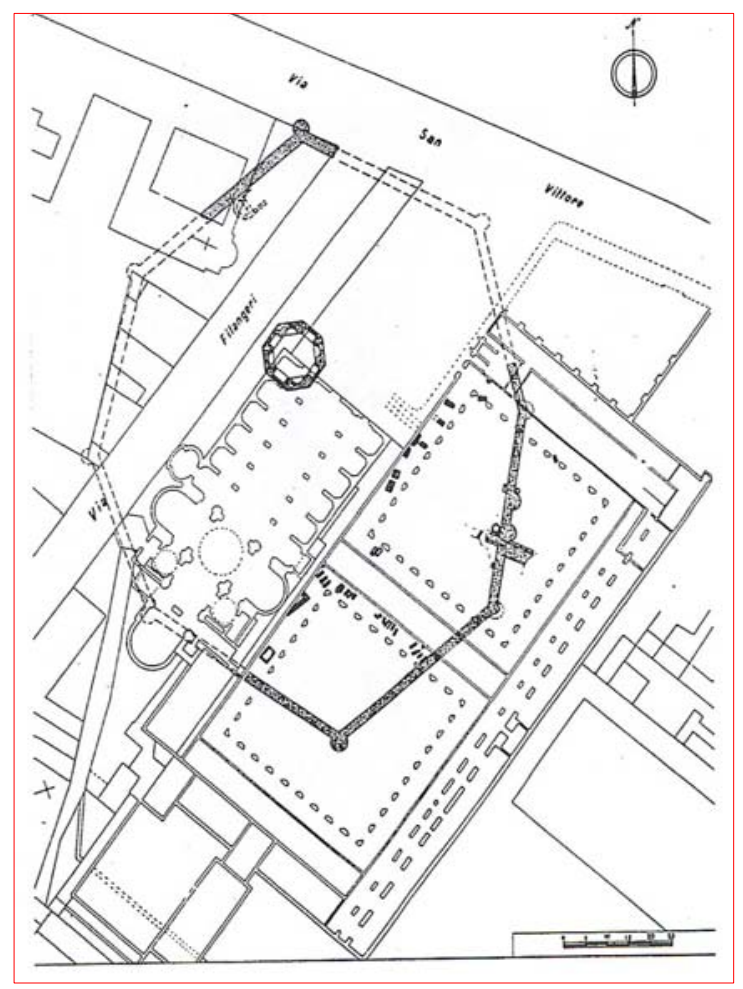

Figure 72: Milan: remains of the octagonal wall and chapel of S. Gregorio an octagonal wall enclosure which circumscribed the area around the basilica.

The small building, which had been converted to the chapel of S. Gregorio, was therefore placed within the enclosure of the villa complex. Although none of the chronology of this structure can be established by the contemporary documents, including when it was re-dedicated to St. Gregory, Verzone and Calderini have both hypothesized that the building was an

\footnotetext{
${ }^{608}$ Edwards (Lewis), "Two Critical Aspects of Fourth-Century Architecture at Milan," 32-33. The Acts of St. Victor $\left(5^{\text {th }}\right.$ c.) and Landalfus Senioris, Historia Mediolanensis $\left(11^{\text {th }} \mathrm{c}\right.$. $)$ attributed the small villa complex to Maximian; which $14^{\text {th }}$ century chronicles continued, noting that the emperors customarily stayed there at the time of their coronation.
} 
imperial mausoleum placed near the imperial villa. The villa's foundations are probably beneath the basilica and the chapel was destroyed by Alessi in 1512 in the reconstruction of the basilica of S. Vittore al Corpo. ${ }^{609}$

The question remains as to which member of the imperial family was interred in the mausoleum and only one is definitively identified as having been buried in Milan: Valentinian II, who was killed at Vienne in 392 and brought to Milan for burial by his sisters Justa and Grata. ${ }^{610}$ A letter from Ambrose to Theodosius (August, 392) offers his condolences to the emperor and mentions the very pragmatic arrangements for the burial, stating, "We have here a very beautiful porphyry vessel, well suited to the purpose; Maximian, the colleague of Diocletian, was so buried." ${ }^{.611}$ Apparently, the chapel did contain a large porphyry sarcophagus, and Theodosius' special devotion to St. Victor would have made the burial of his young, imperial colleague here entirely consistent. ${ }^{612}$

Prior to its destruction, Alessi ensured that detailed drawings of the plan and

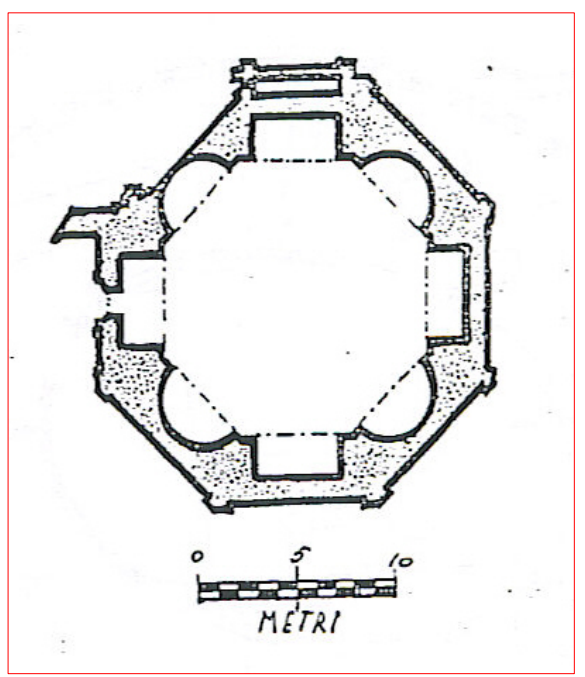
elevation were made of the building. The internal diameter measured $13 \mathrm{~m}$. and had alternating rectangular and semicircular niches cut into the thickness of the interior walls, one of which served as the entrance. It was lighted by large windows placed above each of the interior niches, which suggests the possible existence of an upper internal gallery, and an

Figure 73: Milan: chapel of S. Gregorio (imperial mausoleum)

${ }^{609}$ Edwards (Lewis), "Two Critical Aspects of Fourth-Century Architecture at Milan," 34.

${ }^{610}$ Edwards (Lewis), "Two Critical Aspects of Fourth-Century Architecture at Milan," 37.

${ }^{611}$ Ambrose, Epistolae, 53, 5.

${ }^{612}$ Edwards (Lewis), "Two Critical Aspects of Fourth-Century Architecture at Milan," 35: the sarcophagus was later given by Francesco Sforza to Pandolfo Malatesta (first half of the fifteenth century). 
external gallery was composed of three arches in each side of the octagon above the large windows. ${ }^{613}$ What is interesting about the chapel is that its dimensions and plan correspond exactly to the dimensions of Ambrose's baptistery of S. Giovanni alle Fonti. $^{614}$

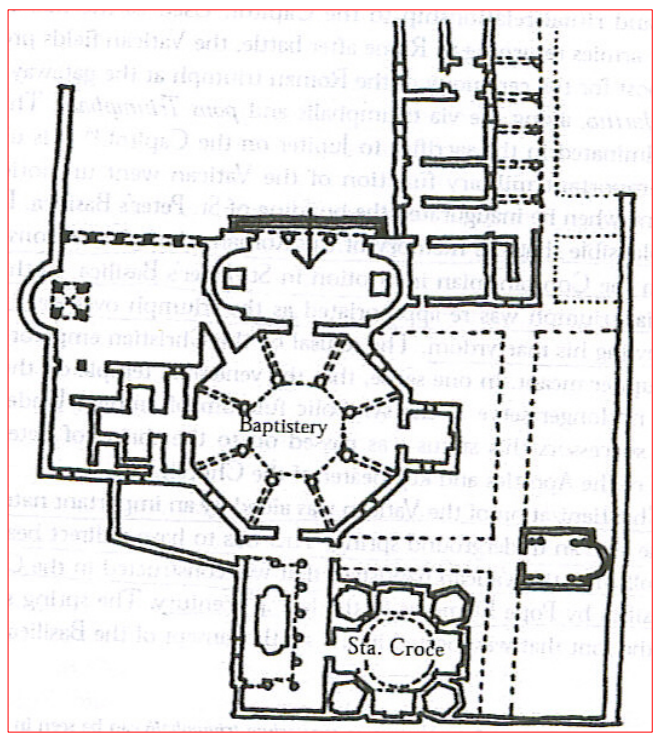

Figure 74: Rome: The Lateran baptistery in the period of Pope Hilarius (461-468)

The Golden Octagon, which Constantine began in 327 . It was dedicated to Harmony, "the divine power that unites the Universe, Church, and Empire" ${ }^{616}$ by
The octagon shape of the baptistery had already received an imperial imprimatur. Krautheimer notes that large, centrally-planned halls, frequently polygonal, were adopted by imperial incumbents, including Nero in the first century ${ }^{615}$ and reappeared in Constantine's palaces and churches in the East, such as the palatine church in Antioch, the

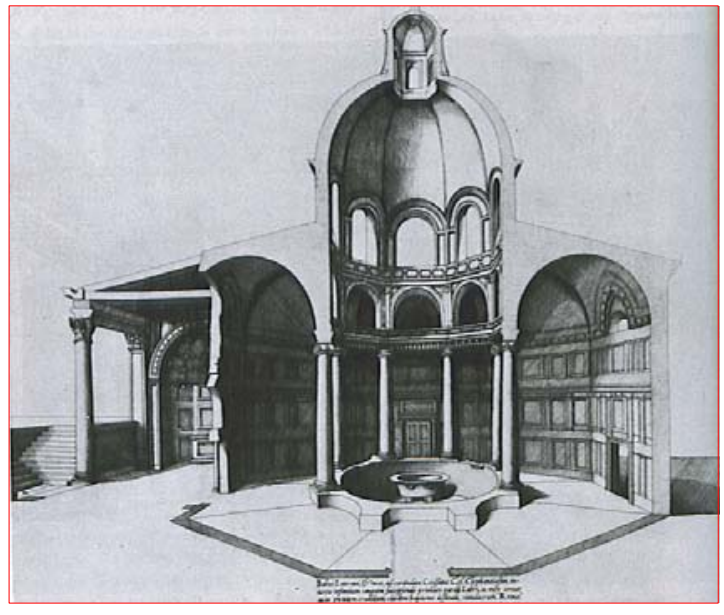

Figure 75: Rome: Reconstruction of the Lateran Baptistery by A. Lafréri, 1560

\footnotetext{
${ }^{613}$ Edwards (Lewis), "Two Critical Aspects of Fourth-Century Architecture at Milan," 34, based on a description written by Castiglione.

${ }^{614}$ Edwards (Lewis), "Two Critical Aspects of Fourth-Century Architecture at Milan," 34.

${ }^{615}$ Krautheimer, Early Christian and Byzantine Architecture, 77.

${ }^{616}$ Krautheimer, Early Christian and Byzantine Architecture, 76.
} 
his son Constantius in 341, two years after the Council of Nicea. ${ }^{617}$ The original baptistery of the Lateran, a circular structure whose font was an adaptation of a pool in the frigidarium of a thermal building, ${ }^{618}$ was replaced in 315 by Constantine with an octagonal building, the inner angles of which included columns donated by the emperor. ${ }^{619}$ The structure was renovated under Sixtus III (432-444); Figure 72 shows the 1560 engraving by A. Lafréri. ${ }^{620}$

If, as Krautheimer avers, the religious and secular functions of these buildings were interlocked, ${ }^{621}$ then in adopting an octagonal shape Ambrose consciously co-opted an imperial prerogative, much as he had done when building the B. Apostolorum on the adventus route of Milan. ${ }^{622}$ The inscription that the bishop added to S. Giovanni alle Fonti translates the new significance of the octagonal shape of the baptistery:

He put up the eight-walled temple and set it to holy use. In this gift of eight sides it was only right to put an eight-sided font: and so the hall of the baptized was built in eights, because in its salvation itself made full circle back to its own people, making its way by the light of resurgent Christ, who scatters the cloister of death and lifts from the grave those who have breathed their last breath, and resolving the repentant guilty of the stain which is their wrong-doing has washed it to nothing in the irrigation of the clean-streaming fountain.

Ambrose, inscription to the Baptistery of S. Giovanni alle Fonti ${ }^{623}$

\footnotetext{
${ }^{617}$ Krautheimer, Early Christian and Byzantine Architecture, 76.

618 Temple, "Conversion and Political Expedience," 26.

${ }^{619}$ Krautheimer, Early Christian and Byzantine Architecture, 90, and Temple, "Conversion and Political Expedience," 27.

${ }^{620}$ Krautheimer, Early Christian and Byzantine Architecture, 90.

${ }^{621}$ Krautheimer, Early Christian and Byzantine Architecture,77.

${ }^{622}$ Temple, "Conversion and Political Expedience," 25, note 46. Temple notes that the ritual meaning of baptism, as a symbolic gateway to the Christian empire, "resonates typographically by the fact that the Baptistery of the Lateran, like the Basilica, is located close to the Porta Asinaria, one of the principal city gates through the Aurelian wall..."

${ }^{623}$ Temple, "Conversion and Political Expedience," 43, citing the Dictionnaire d'archéologie chrétienne et de liturgie, F. Cabrol, H. Leclercq et al. (eds.), Paris, 1907-53, I, col. 1386.
} 
As can be seen from the plan (Figure 76), the baptistery was sited on the southeast corner of the cathedral, adjoining the church with a vestibule-like passage that provided convenient entrance to the structure from the church for the bishop and the baptizands during the period of their catechesis and following the rites of their initiation.

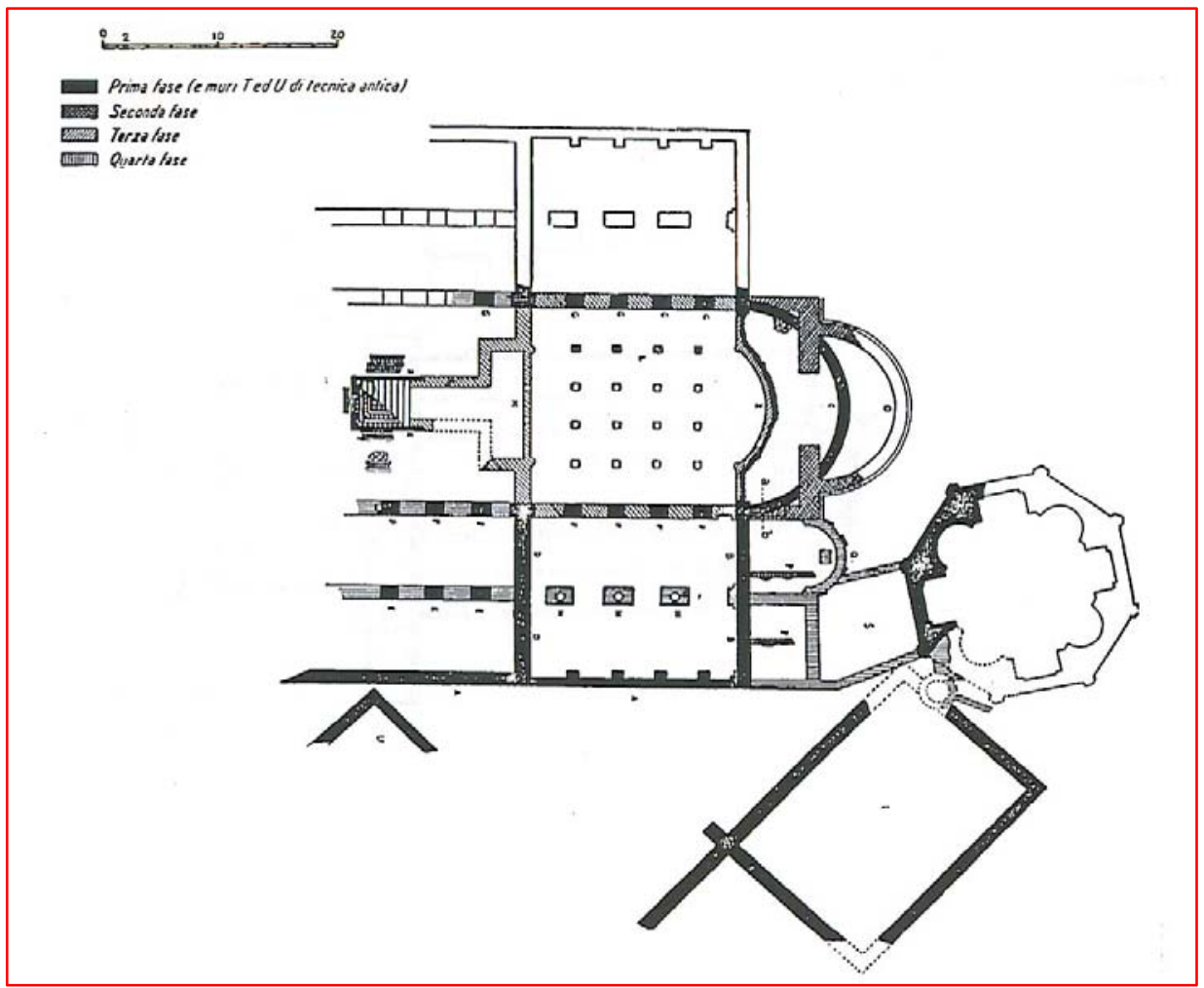

Wharton has indicated that the vestibules were also used for the rites of exorcism that were associated with baptism during the

Figure 76: Milan, S. Tecla with the attached baptistery of S. Giovanni alle Fonti period of the scrutinies. $^{624}$

The little building was fitted with an elaborate hydraulic system to fulfill the injunction of the Didache that the font be fed with living water, as noted above. ${ }^{625}$ As has already been mentioned, the interior of the building was open; the font would have

\footnotetext{
${ }^{624}$ Wharton, "Ritual and Reconstructed Meaning," 361. In Jerusalem, exorcisms followed each of the catechetical lectures; presumably Ambrose would have followed this example (and there are numerous examples in the literature associated with him that speak of the exorcisms that he performed, most notably in the three letters to his sister where he mentions it himself). Male neophytes read out loud to each other while waiting to be exorcized, women were instructed to sing silently (I'm not sure how this was done) "for, says the Apostle, 'I suffer not a woman to speak in church." (Cyril of Jerusalem, Procatechesis, xxxiii. 355B)

${ }^{625}$ Wharton, "Ritual and Reconstructed Meaning," 364.
} 
occupied the central area. Within the octagonal walls, rectangular niches alternated with semicircular interior apses. In the eastern niche, a small altar was placed, as well as a throne for the bishop, and it was from here that the bishop supervised the ritual (the body anointing and immersions having been done by the presbyters and deacons). Ambrose received the newly baptized here, for their anointing with the chrism: “...you went up to the priest" ${ }^{\prime 626}$ to have their faith sealed with an anointment of blessed oil. "There follows a spiritual sign...because after the font there remains the effecting of perfection, when at the invocation of the priest the Holy Spirit is poured forth..."627 Following this last anointing and the washing of their feet by the bishop, ${ }^{628}$ the newly cleansed Christians would have clothed themselves in the white vestments, which they took great pride in providing for themselves, ${ }^{629}$ passed back through the vestibule to the church where the congregation awaited to welcome them.

During the fourth century, baptism was endowed with immense privilege by its linking with the liturgical rite of confirmation (the anointing with chrism), which only the bishop could confer, and as a gateway to full participation in other Christian liturgical expressions, particularly the Eucharist. The structure of the baptistery was likewise privileged. The small structure was entered only once a year (or at the most, twice a year if a baptism was scheduled for Epiphany) and for the baptizands, their initiation was a once in a lifetime experience, for which they were rigorously prepared and instructed. Ambrose alludes to this singular moment, endowed with holiness and awe when he writes in De sacramentis:

\footnotetext{
${ }^{626}$ De mysteriis, vi. 29.

${ }^{627}$ De sacramentis, 3. ii. 8.

${ }^{628}$ De sacramentis, 3, i. 4-7: "For although the presbyters also do this, the highest priest, girded I say, washed your feet."

${ }^{629}$ Wharton, "Ritual and Reconstructed Meaning," 365.
} 
The priests were accustomed to enter the first tabernacle [the church] frequently; the highest priest entered the second tabernacle [the baptistery] once a year...For there was manna in the second tabernacle; there was also the rod of Aaron, that had withered and afterwards blossomed, and the censer... Formerly it [the rod] was dry; afterwards it blossomed: And you were dried, and you begin to flower by the watering of the font. ${ }^{630}$

Architecturally, the octagonal baptistery now epitomized several liturgical functions in the symbolism of its structure. It was a small arena where the Christian 'athelete' of De sacramentis 'wrestled' with the devil for his soul, oiled and naked, witnessed by his Christian family of sponsor, presbyters, and bishop. The arena, where heretofore the martyrs had been baptized by blood, now became the locus of that eschatological re-enactment in the baptism by water, and the triple affirmation of the Divine Persons of the Trinity. And it was here that the new Christian was reborn in the spirit, crowned with precious chrism to take his place among the royal priesthood in a royal building of imperial provenance.

As Peter Cramer writes,

"So much for the Roman inheritance, of which the effect was probably in the end an unspecified residue in the city's mind of romanitas, rather than a catalogue of exact senses. Beside it are the liturgical ideas held fast in the baptistery, above all the two great liturgical ideas of death-and-resurrection and rebirth." 631

\footnotetext{
${ }^{630}$ De sacramentis, iv. 1. 1-2.

${ }^{631}$ Peter Cramer, Baptism and Change in the Early Middle Ages (Cambridge: Cambridge University Press), 1993, 270.
} 


\section{CHAPTER VI}

\section{THE DERIVATIVE FOUNDATIONS}

As we consider the Ambrosian derivative foundations, it might be constructive to revisit the plans of churches south of the Apennines. Rome and its environs adopted the use of the Constantinian basilica with very little alteration or experimentation. ${ }^{632}$ While Krautheimer acknowledges that proportions were manipulated, ${ }^{633}$ in general, monumental church plans consisting of an arcaded and aisled nave, apse, and atrium, the template of the Milanese cathedral of S. Tecla, remained the plan of choice throughout the fifth century. In its most representative form, we see the plan best in the plans for Old St. Peter's and the Lateran, but it was reiterated across the urban landscape of Rome in S. Clemente (ca. 380), SS Giovanni e Paolo, Sta. Sabina (422-32), and numerous other

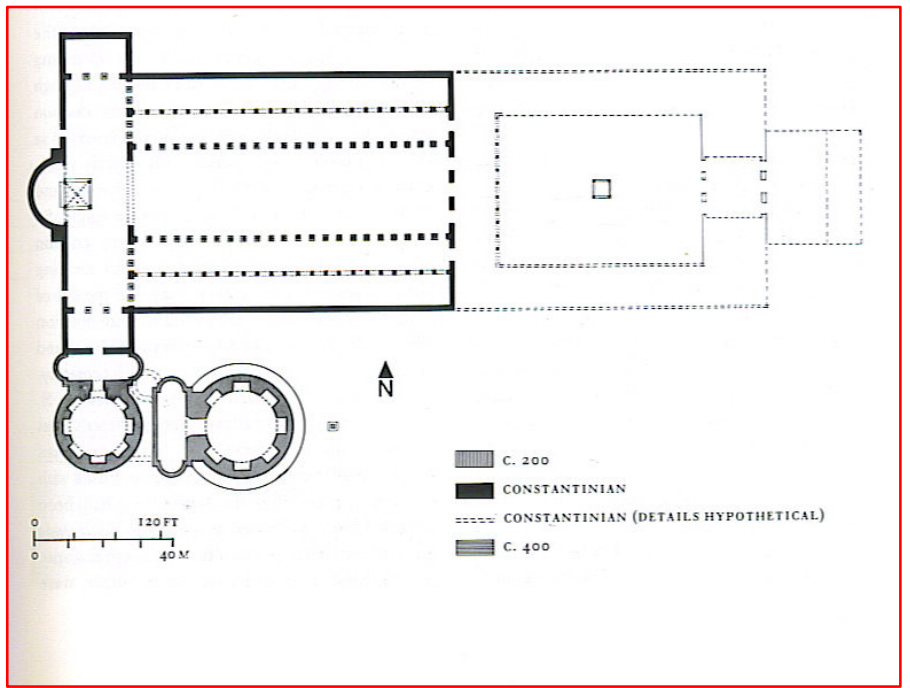

churches.

Both the Lateran plan

(Figure 20) and the plan for Old

St. Peter's (Figure 77) include the addition of the transept, which aligned with the chord of the apse, spanned the aisles of the nave.

Figure 77: Rome, Old St. Peter's Church (begun 319-22).

\footnotetext{
${ }^{632}$ Krautheimer, Early Christian and Byzantine Architecture, 169.

${ }^{633}$ Krautheimer, Early Christian and Byzantine Architecture, 170.
} 
Liturgically, the transept facilitated the movement of the clergy and in pilgrimage churches such as Old St. Peter's, it also provided for orderly movement of pilgrims seeking access to the shrine of the Apostle. However, it is important to recognize that the development of the transept in the Constantinian basilica did not alter the plan essentially. Though defined by a column arcade to separate it from the nave, it remained an extension of the nave. Although the transverse arms of the Milanese plan evolve into transept-like structures, that evolution appears to have been wholly functional, as opposed to architectural.

Consequently, in the early part of the fifth century, the single-naved Latin cruciform church plan, often associated with a dedication to the Apostles, and frequently possessing an accessory martyrial chapel of like cruciform plan, begin to appear across the span of northern Italy. At Como, the Apostoleion (now obscured by S. Abbondio) appears at the beginning of the century, S. Stefano in Verona appears about 450 (but may

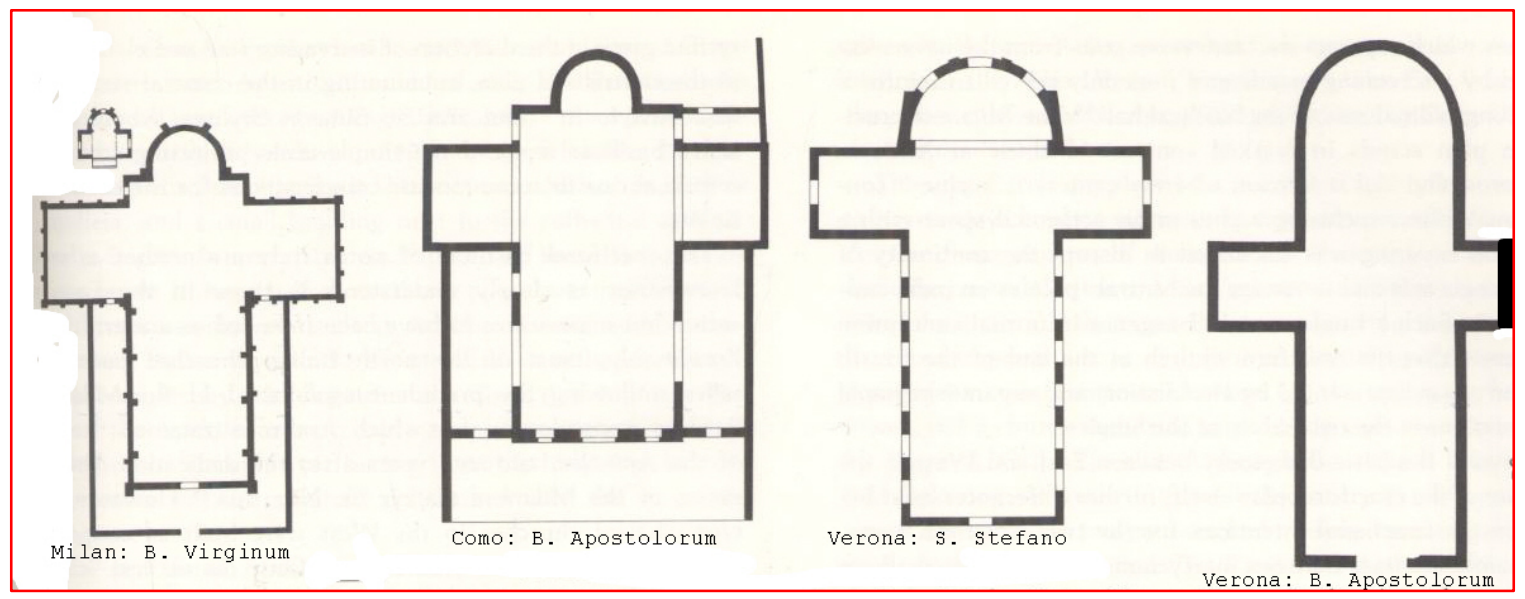

Figure 78: Single-naved cruciform churches of northern Italy, early $5^{\text {th }} \mathrm{c}$. have original foundations as early as 415), Santa Croce of Ravenna was founded circa 425. ${ }^{634}$ Additionally, three other buildings were dedicated to the Apostles between 380

${ }^{634}$ Lewis, “The Latin Iconography,” 210. 
and 390: the B. Apostolorum of Laus Pompeia (Lodi Vecchio, very near Milan), ${ }^{635}$ another at Aquileia, and a third, near Aquileia, as a small building near the cathedral at Concordia Sagittaria. ${ }^{636}$ The northern Italian plans generally negate the central authority of the B. Apostolorum's transverse crossing, moving the arms of the cross closer to the east end of the nave, a modification of the plan that was employed in the Milanese B. Virginum. However, all of the churches retained the pronounced processional axis of the longitudinal hall, which was crowned by the single apse. Additionally, the proportional breadth of the nave increased, which emphasized the aulic character of the churches. As can be seen in Figure 78, the long rectangular rooms on the north and south aisles of the Como church adjoining the arms almost obscure the cross plan. All of the churches were congregational churches; although presumably most of them received relics of the Apostles, possibly from Ambrose himself (or in the case of S. Stefano, of the protomartyr Stephen, whose remains were identified in 415$) ;{ }^{637}$ however, none of them could be considered strictly martyrial. Like the B. Apostolorum, we see the same blurring of purpose between the Eucharistic hall and the martyrium.

It cannot be a coincidence that all of these churches appeared within the several decades after Ambrose's control of the Council of Aquileia in $381,{ }^{638}$ nor can we doubt that the symbolism of the plan of the B. Apostolorum was extended across northern Italy.

\footnotetext{
${ }^{635}$ Lewis, "The Latin Iconography," 212, note 40: We only know of this church because of a reference that Ambrose makes to it in a letter to Bishop Bassianus, Epistolae iv.1)

${ }^{636}$ Lewis, "The Latin Iconography," 213. The foundation of the Aquileian Apostoleion is attributed to Bishop Valerian, who nominally chaired the Council of Aquileia in 383.

${ }^{637}$ The Catholic Encyclopedia Online, s.v. "St. Stephen," http://www.newadvent.org/cathen/14286b.htm (accessed September 24, 2008).

${ }^{638}$ Thirty-two bishops from Italy, Gaul, Africa, and Illyricum attended the council, including Bassianus of Lodi, Eusebius of Bologna, Limenius of Vercellae, Sabinus of Placentia, Abundatius of Brescia, and Diogenes of Genoa, with Valerian of Aquileia chairing. http://www.tertullian.org/fathers/ambrose_letters_01_letters01_10.htm\#Proceedings (accessed September 24, 2008).
} 
The churches of the Cross Triumphant, sanctified with the holy relics of the Apostles as protectors and intercessors, represented Ambrose's characterization of the triumph of orthodoxy in northern Italy, implemented by the bishops aligned to Milan.

However, the B. Virginum was not the only Ambrosian church to provide inspiration for the bishops of northern Italy. Krautheimer has identified churches in Pavia, Brescia, Turin, Vercelli, as well as the cathedral of Verona, which were modeled on the Ambrosiana. ${ }^{639}$ Verona has a raised chancel which was extended into the nave with the solea, but Krautheimer notes that there were few variations on the plan, although there was some tinkering with the form of the apse. ${ }^{640}$ Vicenza (see below) had a rectangular apse, Vercelli had a trefoil apse. Almost all of the derivative foundations were distinguished by the addition of accessory martyrial chapels, ${ }^{641}$ usually taking the form of the cruciform model of the B. Virginum, or alternatively, a Greek cross. ${ }^{642}$

With the structure of the baptistery, an accessory building required for all cathedral churches that was frequently added to parish churches, the Ambrosian model of the octagonal baptistery was adopted wholesale. Kostof identifies at least fourteen cathedral baptisteries which used octagonal plans, ${ }^{643}$ but even an obscure church like SS Felice e Fortunato in Vicenza possessed a baptistery which was octagonal. Of these structures, the Neonian (Orthodox) and Arian baptisteries of Ravenna are perhaps the best preserved. The extraordinary decorative program of the Neonian baptistery, closely

\footnotetext{
${ }^{639}$ Krautheimer, Early Christian and Byzantine Architecture, 175.

${ }^{640}$ Krautheimer, Early Christian and Byzantine Architecture, 175.

${ }^{641}$ Krautheimer, Early Christian and Byzantine Architecture, 175.

${ }^{642}$ Gillian Vallance Mackie, Early Christian Chapels in the West: Decoration, Function and Patronage (Toronto: University of Toronto Press Inc., 2003), p. 35, and Krautheimer, Early Christian and Byzantine Architecture, 175.

${ }^{643}$ Kostof, The Orthodox Baptistery of Ravenna, 52, 53.
} 
linked as the visual representation of the Ambrosian rite of initiation, gives us a clear representation of the importance and value that early Christianity invested in baptism.

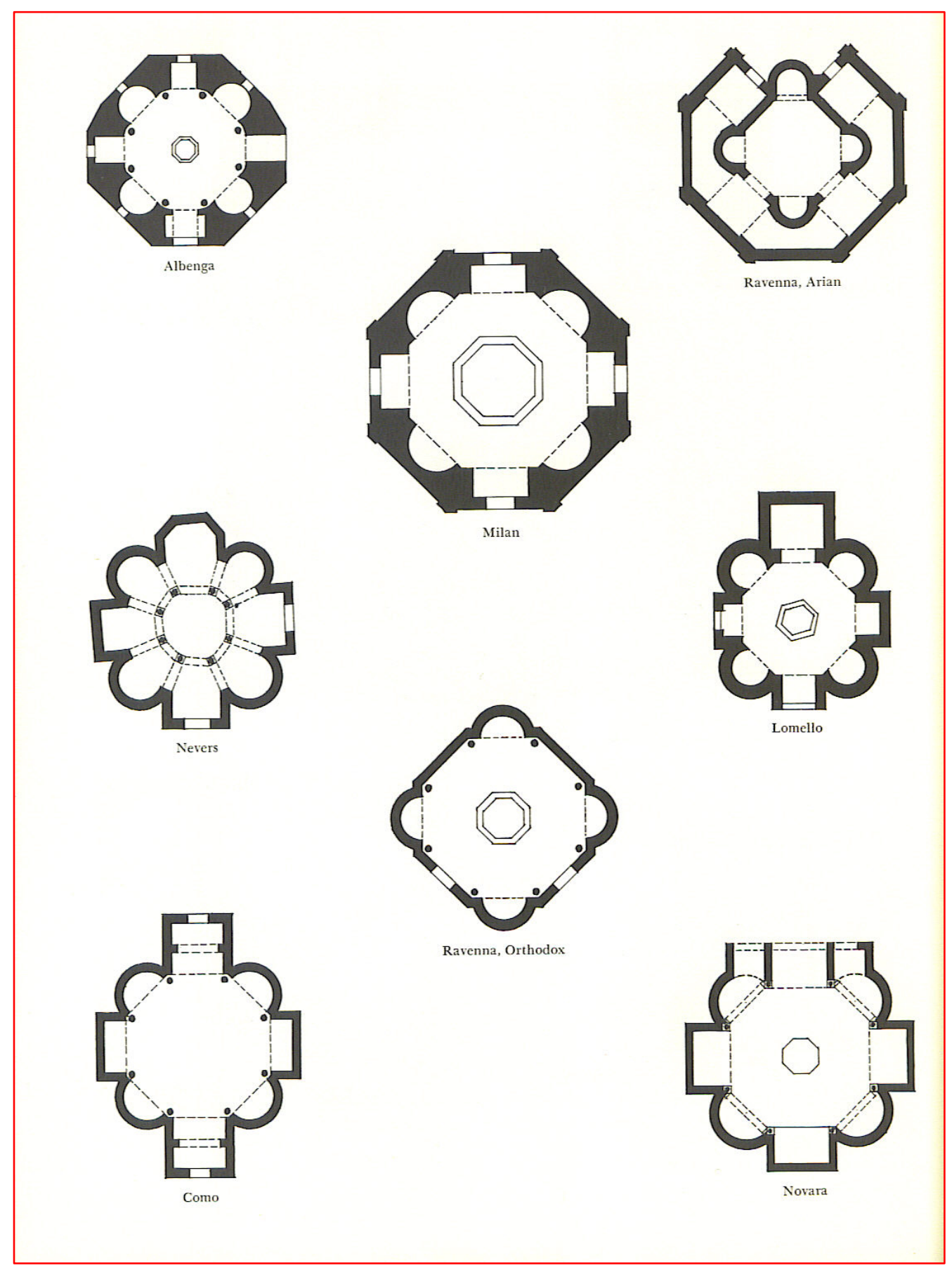

Figure 79: Examples of baptisteries based on the Milanese model in northern Italy and France. 


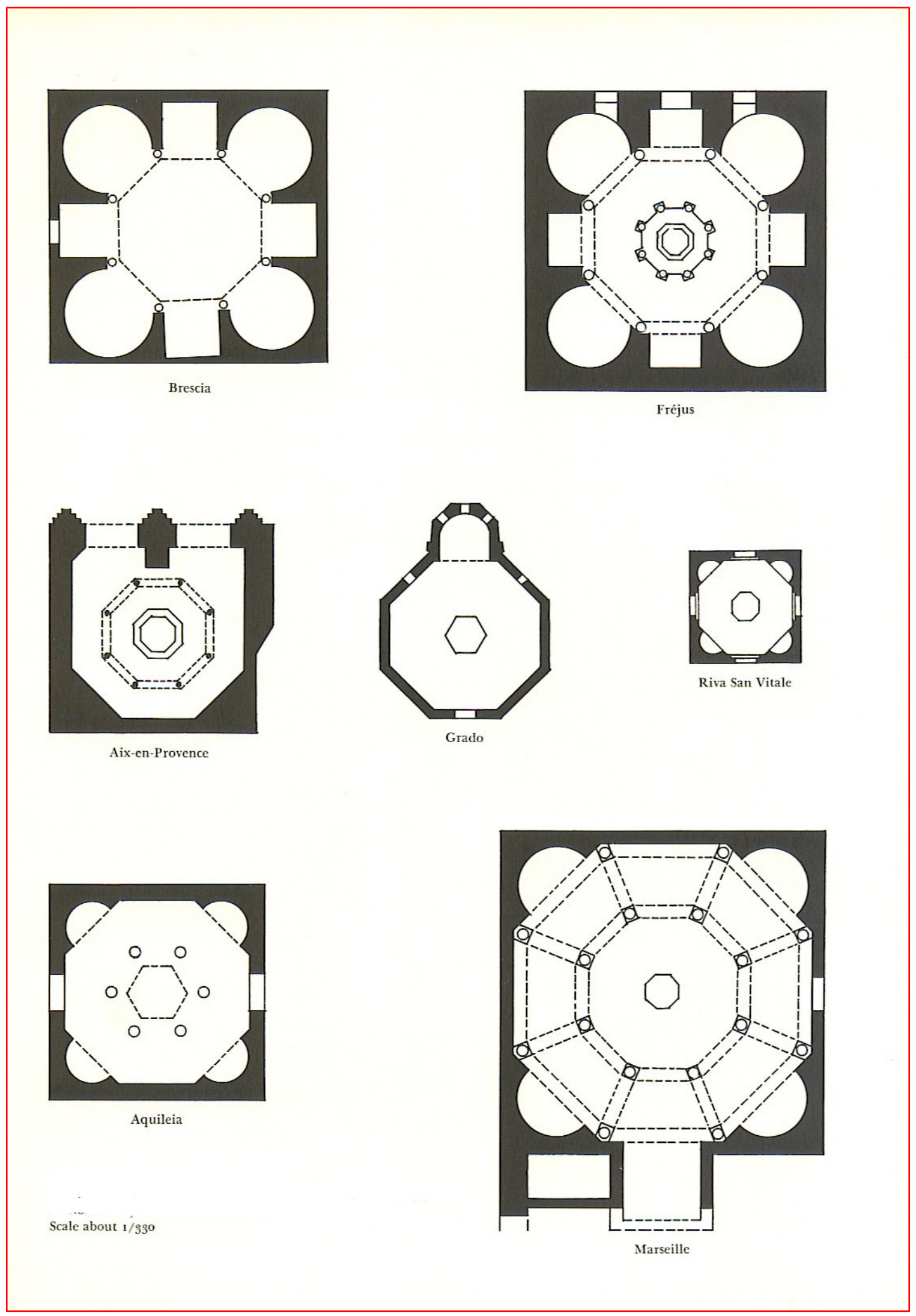

Figure 80: Examples of baptisteries based on the Milanese model in northern Italy and France. 


\section{Verona: S. Stefano}

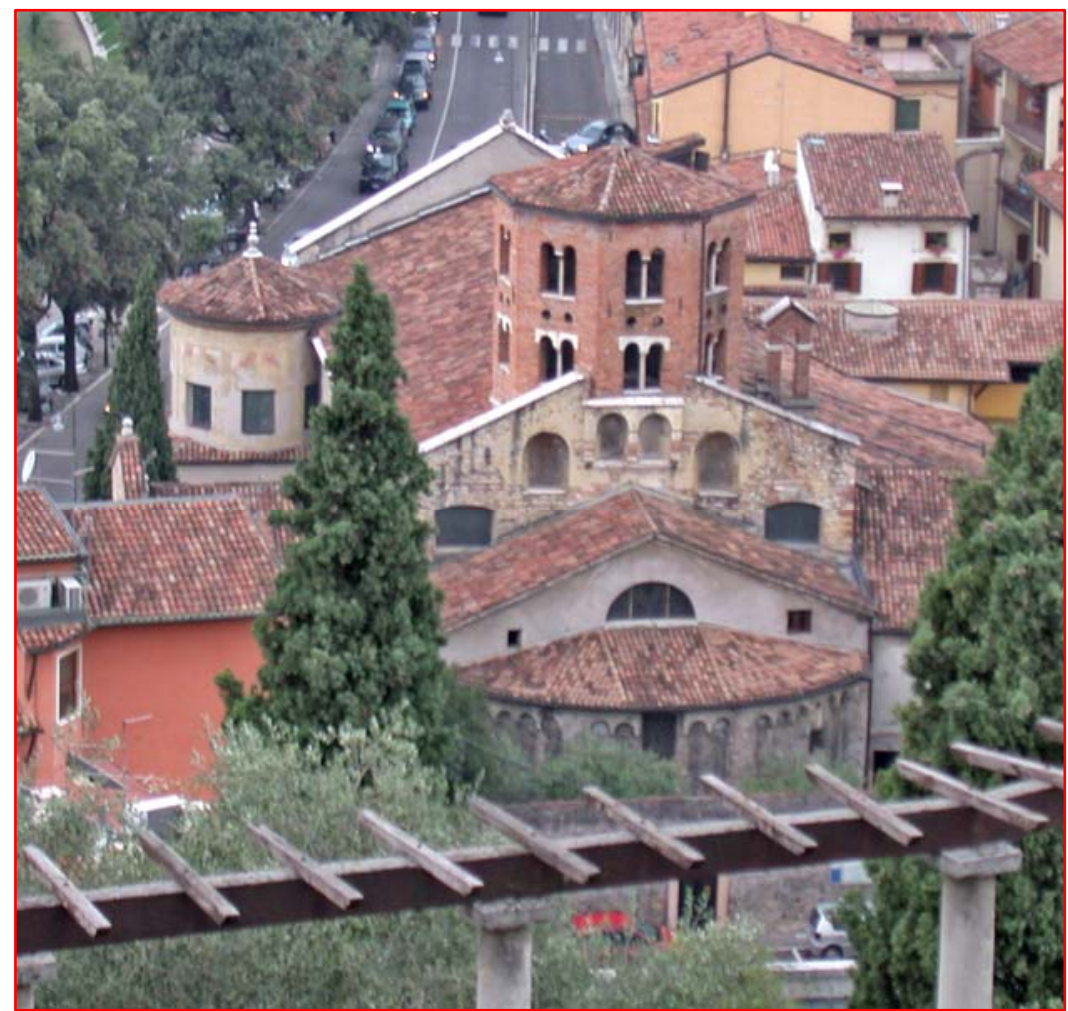

Figure 81: Verona: Aerial view of S. Stefano

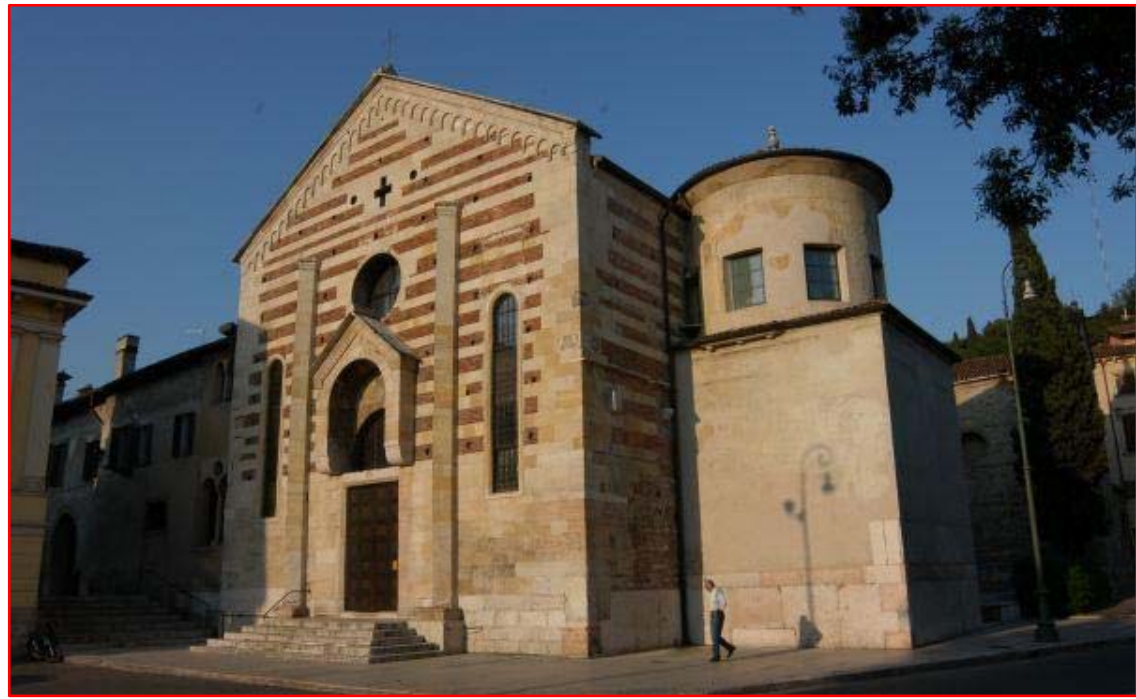

Verona lies

approximately 164

kilometers to the

east of Milan, on

the road that

connects Milan to

Aquileia. Well

Figure 82: Verona, S. Stefano $\left(5^{\text {th }}-12^{\text {th }} \mathrm{c}\right.$. sited on a fork in the Adige River, the city was ancient when the Romans conquered the 
Po valley and occupied the city in 300 BCE. ${ }^{644}$ The remnants of the Roman occupation are still visible, most notably in the preservation of the amphitheatre which today enjoys an international reputation for world class opera which are presented al fresco in the summer.

The city was established as a Christian bishopric perhaps as early as 260, during the peace of the Church extended by the Emperor Gallienus, but more likely, during the early part of the reign of Diocletian, after 284 but prior to the initiation of the persecution of Christians in 303. In the fourth century, Verona was a suffragan of Milan; ${ }^{645}$ its bishop during the time of Ambrose was the African bishop St. Zeno, well-beloved and a force to be reckoned with in his own right, who became the patron saint of the city. He died in 380 and was succeeded by Syagrius, who is not listed among the bishops who attended the Council of Aquileia. ${ }^{646}$ It is possible that no incumbent had yet been consecrated at the time of the council.

Verona is blessed with churches, although very few churches retain their Early Christian fabric, having been rebuilt as Romanesque churches. A massive earthquake in 1117 played its part in the destruction; with the exception of the apse, the entire church of S. Stefano was rebuilt following the earthquake. A survey of the list of the city's churches is an interesting exercise, since many of the dedications are to the saints of the Milanese litany, which have no local connection at all. These include S. Eufemia, SS Nazaro e Celso, and Sta. Anastasia, as well as the church dedicated to the Apostles mentioned above.

\footnotetext{
${ }^{644}$ The Catholic Encyclopedia Online, s.v. "Verona," http://www.newadvent.org/cathen/15360a.htm, (accessed April 3, 2008).

${ }^{645}$ Paolo Lino Zovatto, “Arte Paleocristiana a Verona," Verona e il suo territorio, 1960, 357.

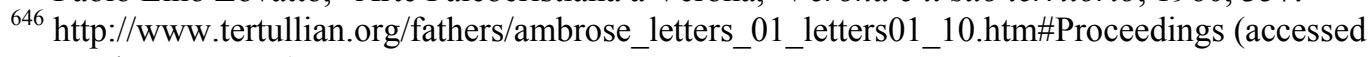
September 24, 2008).
} 


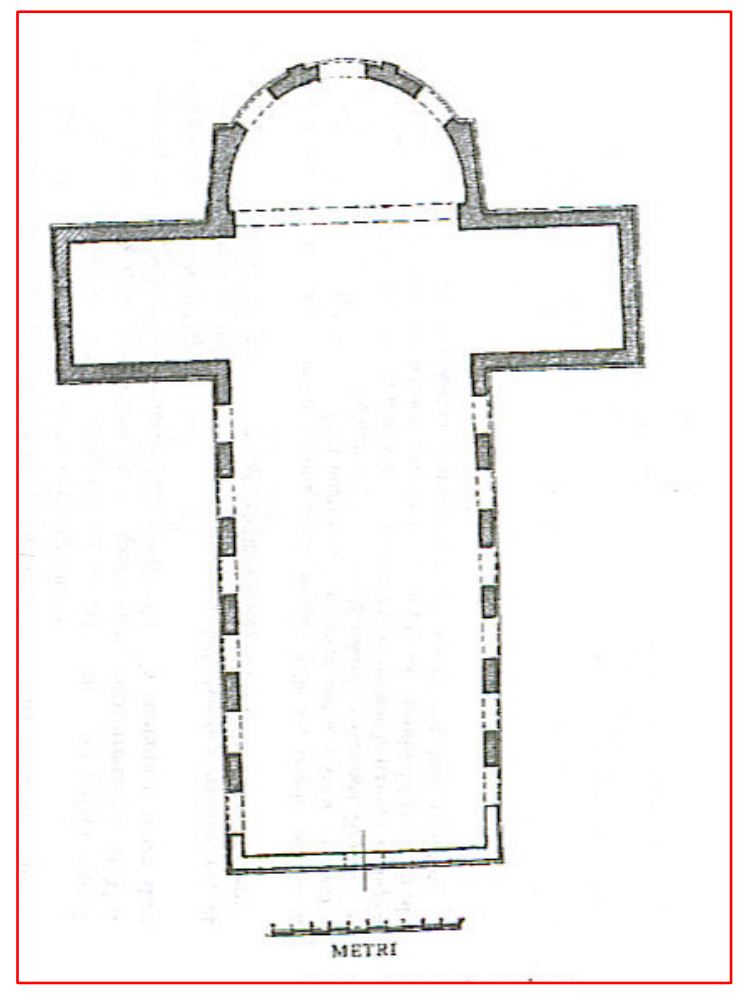

Figure 83: Verona, S. Stefano $\left(5^{\text {th }} \mathrm{c}.\right)$
With the discovery of the protomartyr Stephen's remains in 415 and the dispersion of the relics, the tentative dating of the church is probably after 415 but perhaps no later than $450 .{ }^{647}$ S. Stefano was a suburban church, placed just outside the Roman wall of the city on high ground. ${ }^{648}$ All that is left of the original church is the footprint of its plan, a large single-naved Latin cross, $40 \mathrm{~m}$. long from the west entrance to the curve of the apse, the nave $12.50 \mathrm{~m}$. wide.

The transverse arms are $6.5 \mathrm{~m}$. long by $8 \mathrm{~m}$. wide, with the eastern walls aligned to the chord of the apse. The nave had two aisles, separated by arcades of columns; the nave and aisles shared a timbered roof. ${ }^{649}$ As we see it today, the church is constructed of tufa and brick, which may have been the original building material as well. In common with many churches of this period and location, the pavements were mosaic, unlike the churches of Milan which had marble revetement pavements. Zovatto indicates that the mosaics were identical to the pavements found in Vicenza in SS Felice e Fortunato (see below), indicating a common preference for the pattern and material, and perhaps a common workshop. ${ }^{650}$

\footnotetext{
${ }^{647}$ Lewis, "The Latin Iconography," 210.

${ }^{648}$ Zovatto, "Arte Paleocristian a Verona," 581.

${ }^{649}$ Krautheimer, Early Christian and Byzantine Architecture, 175.

${ }^{650}$ Zovatto, "Arte Paleocristian a Verona," 564; SS Felice e Fortunato is contemporary with S. Stefano.
} 


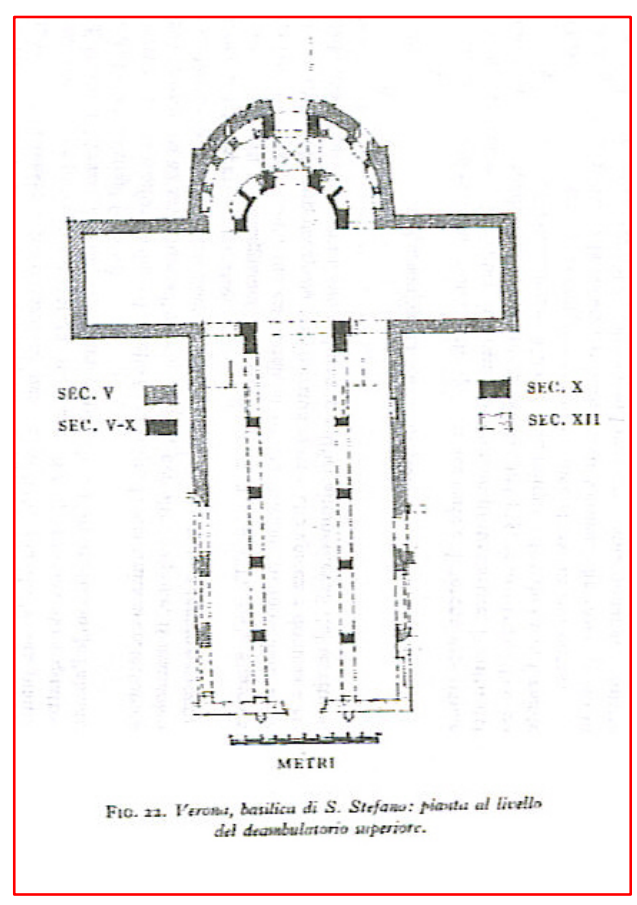

Figure 84: Verona, S. Stefano, lower ambulatory $\left(6^{\text {th }} \mathrm{c}.\right)$

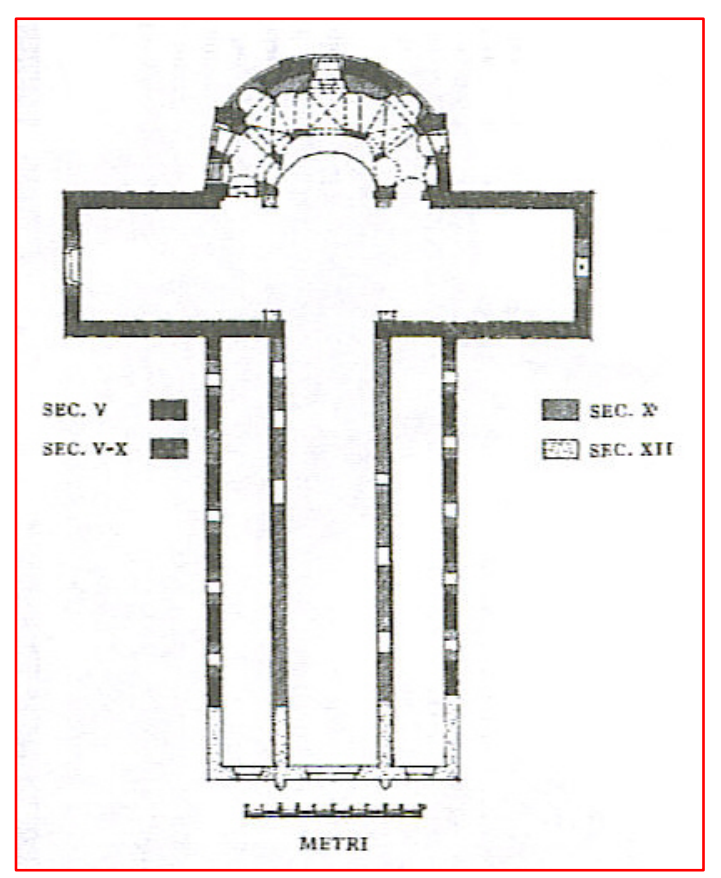

Figure 85: Verona, S. Stefano, upper ambulatory $\left(6^{\text {th }}\right)$

What is interesting about this church is that it apparently had an upper-level gallery, an innovation that departed from the Milanese plans. In 485 the Goths occupied the city, and Theodoric made Verona his residence in the north. ${ }^{651}$ In 520 , he ordered that S. Stefano be renovated and at that time, the church was given a double ambulatory, upper and lower level which encompassed the upper gallery; the lower ambulatory intrudes into the apse, which was also reconstructed. ${ }^{652}$ Both ambulatories are columned, including the intrusions into the apse; the lower ambulatory engages the transverse crossing which forms the transept. When the church was rebuilt in the twelfth century, it was apparently reconstructed on the same plan, the columns having been the only aspect

\footnotetext{
${ }^{651}$ The Catholic Encyclopedia Online, s.v. "Verona," http://www.newadvent.org/cathen/15360a.htm, (accessed April 3, 2008).

${ }^{652}$ Zovatto, "Arte Paleocristian a Verona," 586-88.
} 
of the church to survive the earthquake. ${ }^{653}$ Zovatto does not cite any contemporary sources to explain Theodoric's extensive and expensive reconstruction of the church, but we can perhaps infer that it was in response to (or in anticipation of) the press of pilgrims seeking the relics of S. Stephen. The original church was graced by a quadriporticus atrium; ${ }^{654}$ this has been lost, and it is possible that Theodoric used those columns to create his ambulatories.

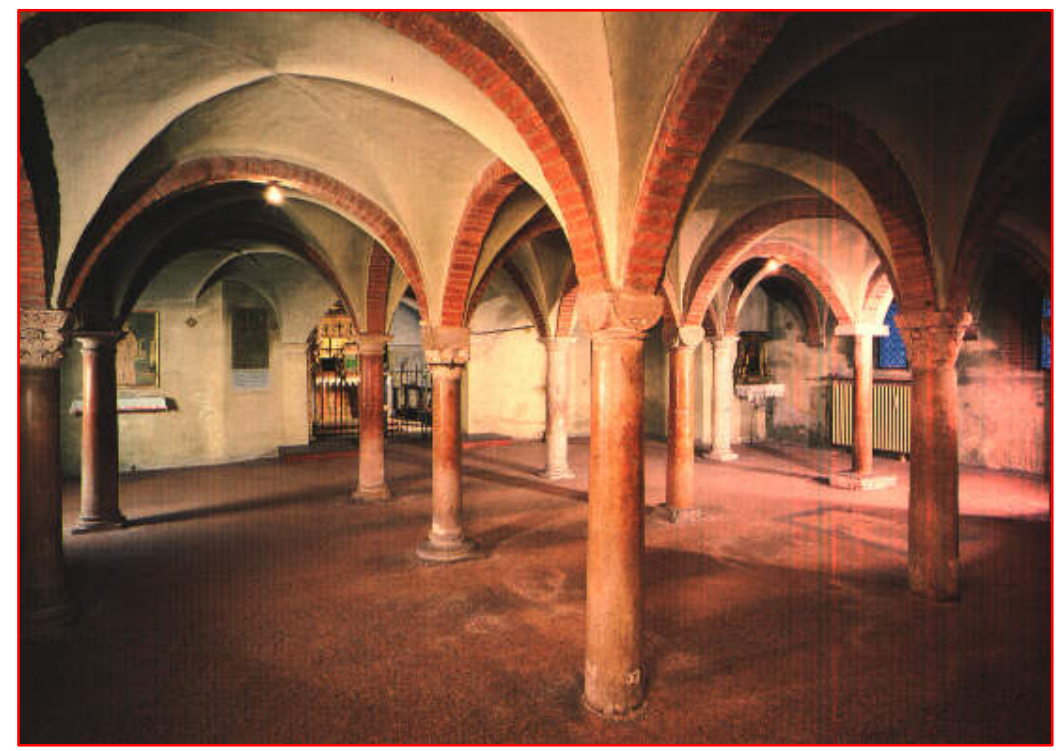

Figure 86: Verona, S. Stefano, crypt $\left(5^{\text {th }}-12^{\text {th }} \mathrm{c}.\right)$

${ }^{653}$ Zovatto, "Arte Paleocristian a Verona," 586-588.

${ }^{654}$ Zovatto, "Arte Paleocristian a Verona," 585. 


\section{Vicenza: SS Felice e Fortunato}

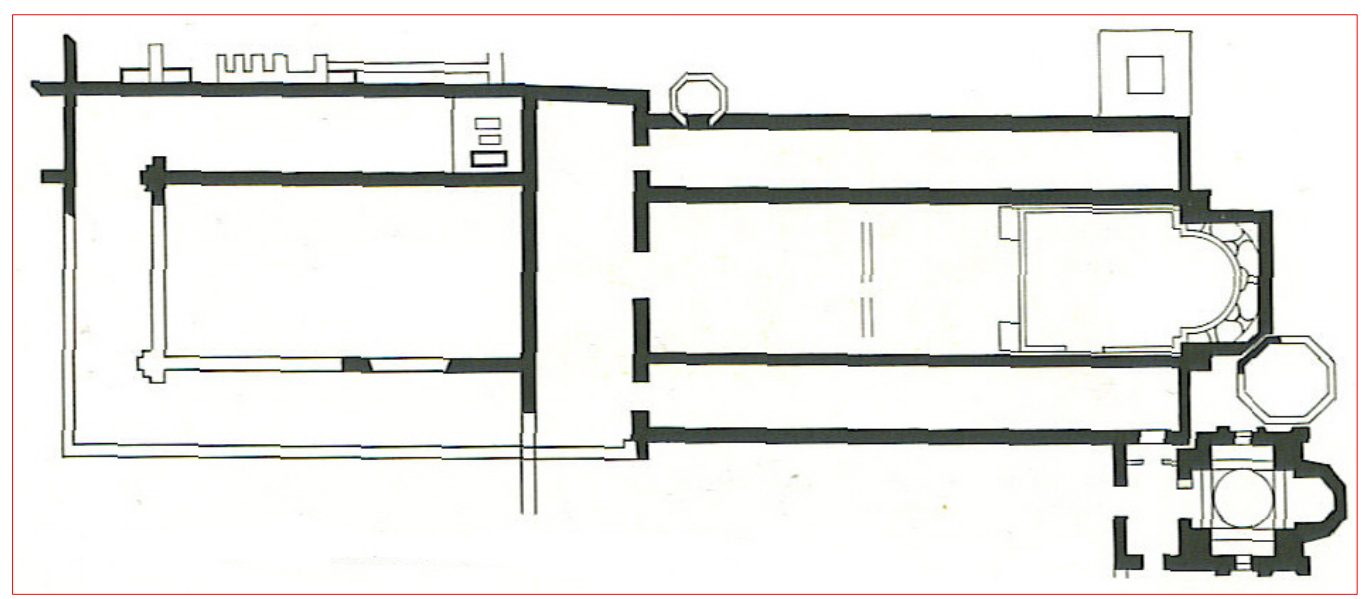

Figure 87: Vicenza: SS Felice e Fortunato, plan showing the small octagonal baptistery and the chapel of Sta. Maria Mater Domini (c. 400)

The town of Vicenza lies about 45 kilometers to the east of Verona and almost

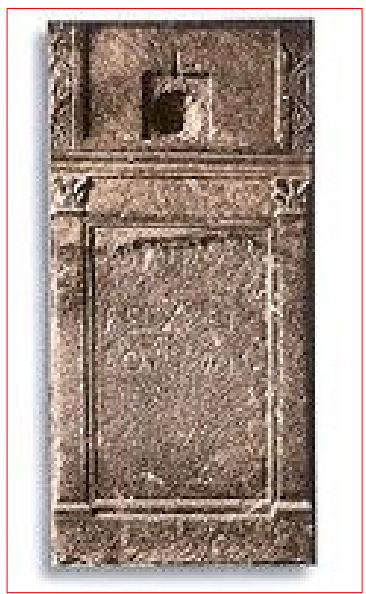

Figure 88: Vicenza: Cemeterial stele of SS Felice e Fortunato
210 kilometers east of Milan. The original foundations of the church SS Felice e Fortunato appear to have been a memorial hall which was built with the return of the martyrs outside the walls of the city, or it may have been a cemeterial hall. The sarcophagus of the martyrs Felix and Fortunatus, who were executed during the period of Diocletian, was found in a Roman cemetery near the city, where they were apparently interred when they were returned to the city during the fourth century. The veneration of the two

saints appears to have been a very early practice, and it is very likely that they may have been local to the area. Their grave was marked by a stele which was inscribed: BEATIMART/TURES/FELIX ET/ FORTUNA/TUS. ${ }^{655}$ The stele was equipped with a

\footnotetext{
${ }^{655}$ Mackie, Early Christian Chapels in the West, 37.
} 
hole so that contact with the relics could be maintained, a variation on the fenestrella confessionis. ${ }^{656}$

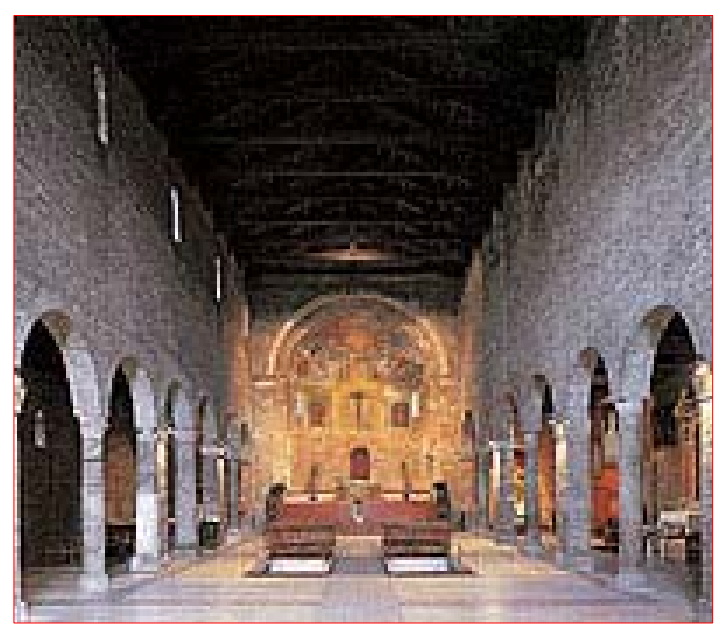

The hall was rebuilt as a basilica in the latter part of the fourth century at which time the decapitated body of Felix was translated to the church, while the relics of Fortunatus were given by Ambrose to Aquileia, consonant with his practice of distributing relics. ${ }^{657}$ The basilica, the plan

Figure 89: Vicenza, SS Felice e Fortunato, interior nave and arcades $\left(5^{\text {th }} \mathrm{c}\right.$.).

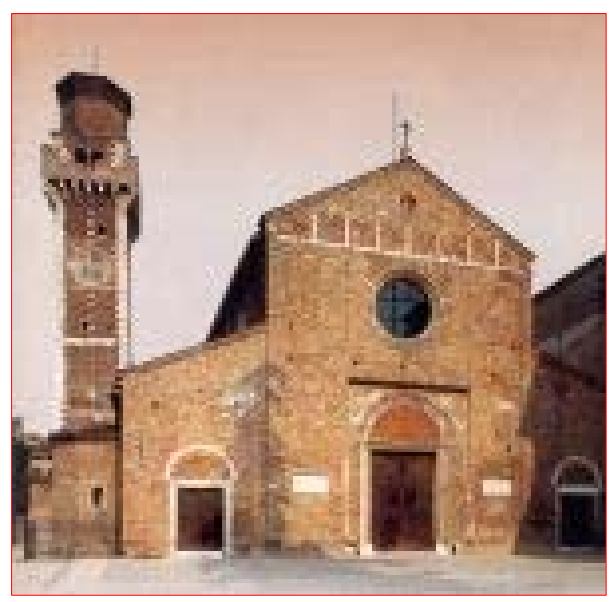

Figure 90: Vicenza, SS Felice e Fortunato, west façade $\left(5^{\text {th }} \mathrm{c}\right.$.). of which Krautheimer notes is based on the B. Martyrum (Ambrosiana), ${ }^{658}$ is a very standard, aisled basilica. The aisles are arcaded on either side, supported by a nine column sequence; there is a raised solea and the ambos are placed well forward. Of interest is the apse which was rectangular on the exterior, but semicircular on the interior, as well as the addition of the narthex. This particular architectural

\footnotetext{
${ }^{656}$ It is very likely that this stele originally may have been a Roman cemeterial libation stele.

${ }^{657}$ Humphries, Communities of the Blessed, 54-55.

${ }^{658}$ Krautheimer, Early Christian and Byzantine Architecture, 175.
} 
addition, which George Gerov has characterized as the spiritual desert of the church, ${ }^{659}$ is more commonly seen in Eastern churches. Liturgically, it was often used for the purpose of segregating the catechumens from the baptized initiates. Its presence in this small, provincial basilica is unusual and intriguing, the architectural expression of the continuing archaicism of the Milanese liturgy and its Eastern elements.

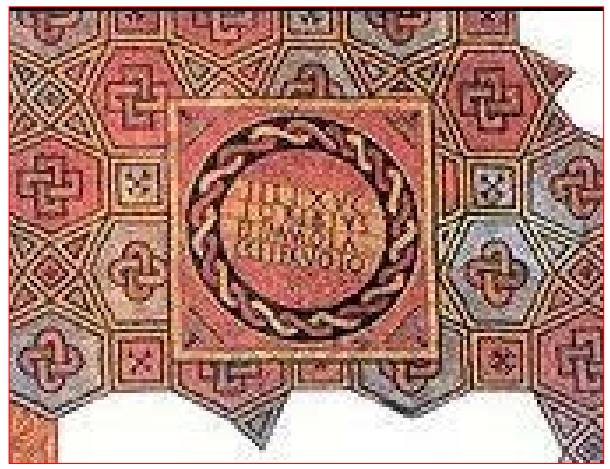

Through periodic destructions, ${ }^{660}$ the church continued to be rebuilt, almost exactly as it was in its initial conceptual iteration, the only difference being that the apse achieved an exterior semicircular form and the church eventually lost its

Figure 91: Vicenza, SS Felice e Fortunato, central nave mosaic $\left(5^{\text {th }} \mathrm{c}\right.$.) atrium when it was assimilated into a Benedictine monastery in the eighth century. Its small, octagonal baptistery has shifted position from its original position on the northeast corner, which is now occupied by the Romanesque campanile, to its position in Mackie's plan, nestled between the apse and the small chapel of Sta. Maria Mater Domini. This small chapel, constructed in the mid-

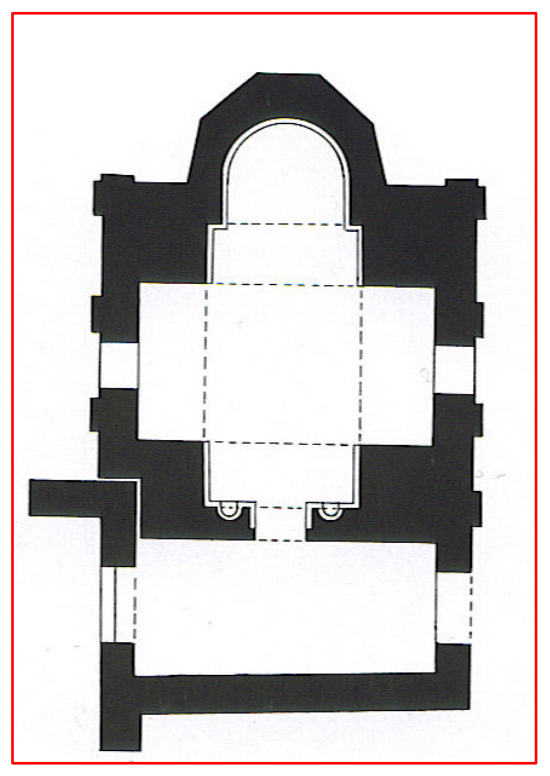

Figure 92: Vicenza, SS Felice e Fortunato, Plan of the Chapel of Sta. Maria Mater Domini (after Arslan $\left(6^{\text {th }}\right.$ c. $)$

\footnotetext{
${ }^{659}$ George Gerov, "The Narthex as Desert: The Symbolism of the Entrance Space in Orthodox Church Buildings," Ritual and Art: Byzantine Essays for Christopher Walter, ed. Pamela Armstrong. London: The Pindar Press, 2006.

${ }^{660}$ By the Huns in 899 and by earthquake in 1117.
} 
sixth century, ${ }^{661}$ is all that remains of the early Christian fabric of the church. Only $4 \mathrm{~m}$. square, it is a vaulted Greek cross, beautifully enhanced in miniature with an apse, cupola, and a small, barrel-vaulted narthex that can be entered on either end. ${ }^{662}$ In 1979, the relics of St. Felix were moved from the crypt of the church to this little chapel which is about the same size as S. Vittore in Ciel D'Oro (S. Satiro) that adorned the B. Martyrum.

The church featured some lavish decorations: consistent with this area of Italy, floor mosaics were used to decorate the pavement of the nave, portions of which remain. Within the chapel,

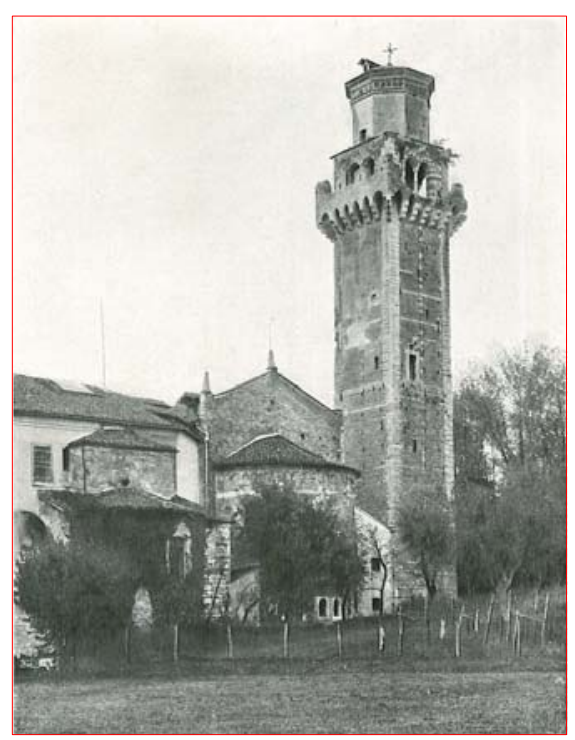
there are also remnants of some wall mosaics which feature an unnamed saint, and the lion of St. Mark, a certain indication Figure 93: Vicenza, SS Felice e Fortunato, east façade showing the current semi-circular apse and campanile. that by the eigth century, the city of $\left(9^{\text {th }}-12^{\text {th }} \mathrm{c}\right.$.

Vicenza and the province of the Venetie had become a suffragan of Venice (the Venetians having adopted the Apostle Mark as their patron).
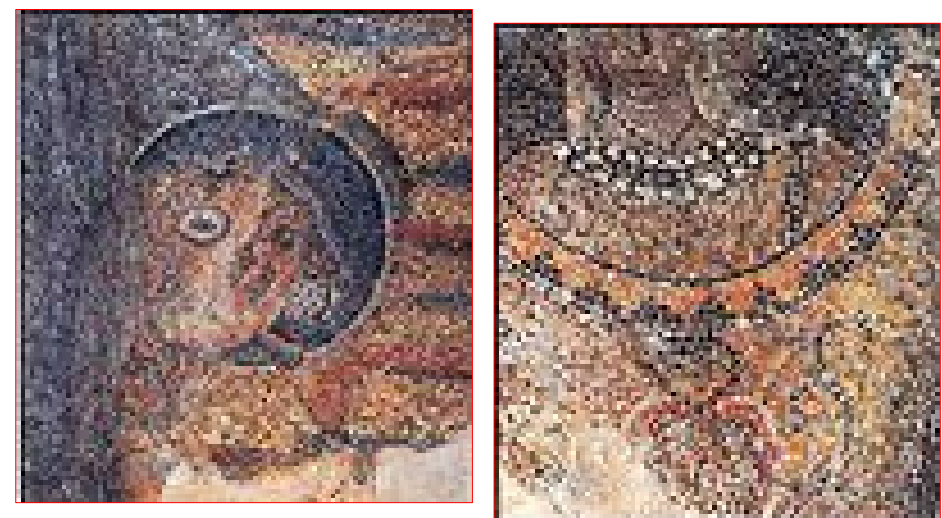

Figure 94: Vicenza, SS Felice e Fortunato, wall mosaic fragment from the Chapel of Sta. Maria Mater Domini $\left(8^{\text {th }} \mathrm{c}\right.$. $)$

${ }^{661}$ Mackie, Early Christian Chapels in the West, 37.

${ }^{662}$ Mackie, Early Christian Chapels in the West,37. 


\section{Padua: The Oratory of S. Prosdocimo}

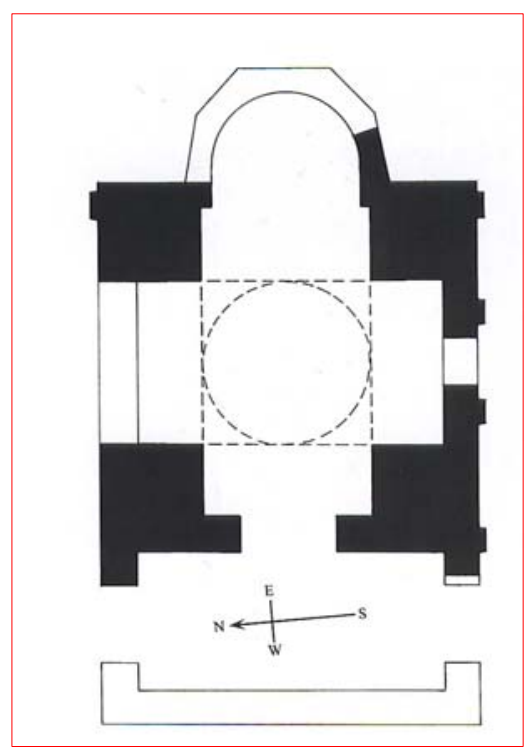

Figure 95: Padua: Plan of the Oratory of S. Prosdocimo

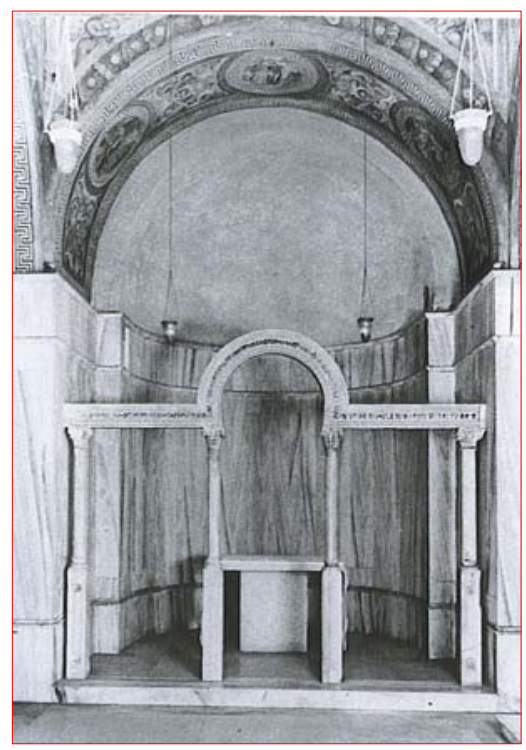

Figure 96: Padua: Oratory of S. Prosdocimo, interior, apse

The addition of small oratories, like Ambrose's use of S. Vittore in Ciel d'Oro in the Ambrosiana, became a fixture of the northern Italian churches. ${ }^{663}$ But this small chapel dedicated to St. Prosdocimus, attached to the huge sixteenth century church of Sta. Giustina, is also an example of the peculiar turns that the cult of the saints could take in the early Christian environment of northern Italy. The episcopal lists of Padua date from the thirteenth century, ${ }^{664}$ but its first bishop, Crispinus, who held the see in the $340 \mathrm{~s}$, is not included. ${ }^{665}$ Instead, Prosdocimus is given that honor. He suddenly appears in the sixth century, closely aligned with Saint Justina, and was interred in this chapel; his sarcophagus refers to him as 'bishop and confessor' ${ }^{666}$ Neither of these saints is listed in

\footnotetext{
${ }^{663}$ Krautheimer, Early Christian and Byzantine Architecture, 175.

${ }^{664}$ Humphries, Communities of the Blessed, 58.

${ }^{665}$ Humphries, Communities of the Blessed, 59.

${ }^{666}$ Humphries, Communities of the Blessed, 59.
} 
the Martyrologium Hieronymianum, but, like St. Zeno of Verona, Prosdocimus had an extraordinary literary life. In an eleventh century Vita, he is portrayed as a disciple of Peter who was martyred in the persecution of Maximian (286-306), a life-span of nearly three centuries. ${ }^{667}$ I think it is safe to infer that both Prosdocimus and Justina enjoyed a tradition of local veneration; the fact that their cult had spread to Verona by the tenth century $^{668}$ is an indication of its significant persistence. Both Prosdocimus and Justina are included in the Ambrosian canon and the Ravenna canon; ${ }^{669}$ Prosdocimus' supposed association with St. Peter is a further indication of the need to elevate the importance of the see of Padua with an apostolic connection. In fact, the church of Sta. Giustina is a virtual reliquary. In addition to St. Justina and Bishop St. Prosdocimus, relics of St. Daniel the Martyr, the evangelists St. Luke and St. Mark, St. Felicity, and three of the Holy Innocents are deposited there. The original church, a fifth century foundation, was rebuilt many times, notably after the earthquake in 1117 . The present church is a sixteenth century iteration; the only thing left of its early Christian fabric is this tiny oratory, which Krautheimer dates to $500-507 .{ }^{670}$

\footnotetext{
${ }^{667}$ Humphries, Communities of the Blessed, 59.

${ }^{668}$ Humphries, Communities of the Blessed, 59.

${ }^{669}$ Mackie, Early Christian Chapels in the West, 41.

${ }^{670}$ Krautheimer, Early Christian and Byzantine Architecture, 175.
} 


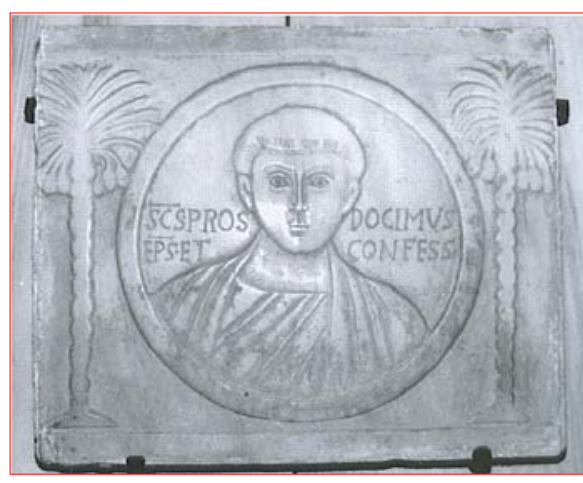

Figure 97: Padua: Oratory of S. Prodocimo, panel from sarcophagus

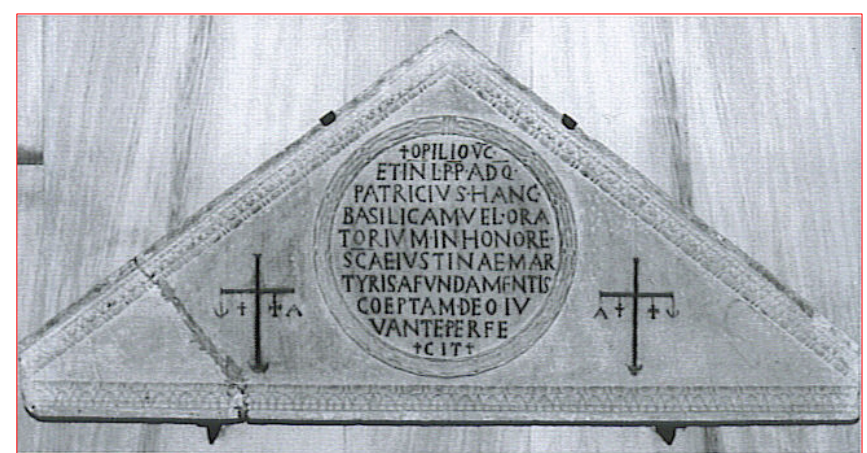

Figure 98: Padua: Oratory of S. Prodocimo, dedicatory lintel

The chapel has been well-restored, and although its beautiful mosaics were lost (probably in the earthquake), the inscriptions remain. The dedicatory panel (shown in Figure 98) reveals that the patron of the chapel was a patrician named Venantius Opilio, who may have been a prefect of Theodoric. ${ }^{671}$ The dedicatory tympanum was originally mounted on two columns which formed the lintel of the tiny narthex of the chapel. ${ }^{672}$

${ }^{671}$ Humphries, Communities of the Blessed, 59.

${ }^{672}$ Mackie, Early Christian Chapels in the West: Decoration, 40. 


\section{Ravenna: The Neonian Baptistery}

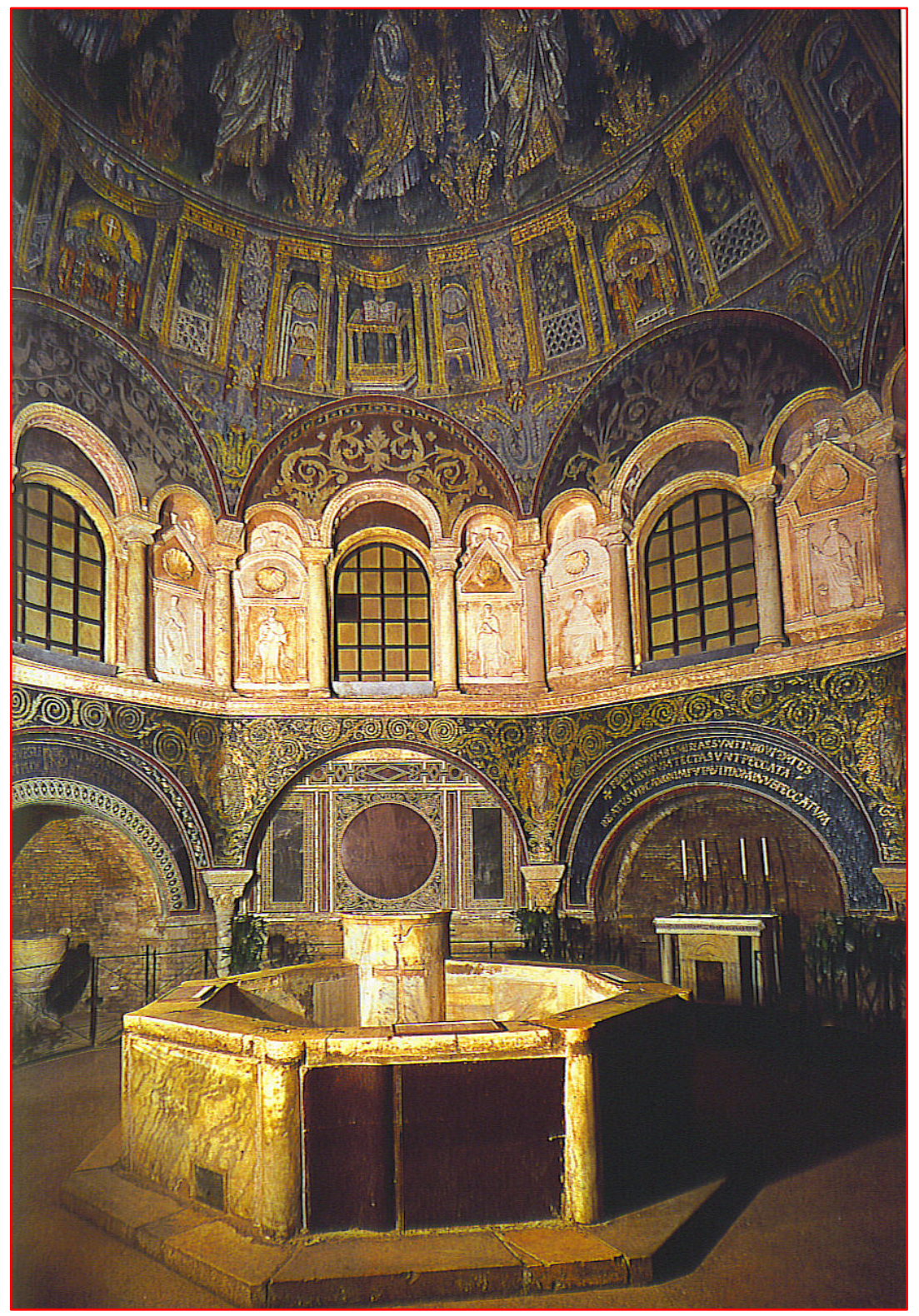


Figure 99: Ravenna, interior of the Neonian Baptistery $\left(5^{\text {th }} \mathrm{c}\right.$.)

In 402 , increasing pressure from the north by migratory tribes caused the emperor Honorius to remove the imperial honor from Milan and relocate his capital to Ravenna, close to the Adriatic Sea. The loss to Milan was significant: not only was it left vulnerable to invasion, but portions of the Milanese see were detached to enhance the see of Ravenna, which now became a suffragan of Rome (as noted above). Ravenna, of course, enjoyed the benefits of the imperial presence, especially since the members of the imperial family, particularly the emperor's half-sister, Galla Placidia, ${ }^{673}$ were enthusiastic builders of Christian structures. The Neonian Baptistery, which is often called the Orthodox Baptistery to distinguish it from the Arian baptistery built by Theodoric (end of the fifth century beginning of the sixth century), represents the best-preserved example of an early fifth century Milanese baptistery. Its extraordinary decorative program, definitively linked to the Ambrosian rite of baptism, speaks to the privileged investment with which the Early Christian Church endowed the ceremonies of initiation.

Until the arrival of the imperial family, Ravenna had no monumental cult buildings, although the adjacent port of Classis had the B. Probi, built by Bishop Probus

${ }^{673}$ The Augusta Galla Placidia (392? - 450) survived harrowing times and managed to prevail. The daughter of Theodosius I, she was raised in the household of Stilicho and his wife Serena. Married by her half-brother Honorius to the Visigothic successor to Alaric, Athaulf, she was returned to the imperial family following Athaulf's death. Forced to make a reluctant marriage with Flavius Constantius, who had succeeded Stilicho in the West as regent and ultimately Augustus (as a usurper), her political value was finally recognized (and her status) by Theodosius II, who named her regent in the West when her young son by Constantius, Valentinian III, succeeded to the throne. She is credited with building the church S. Giovanni Evangelista, the large cruciform church dedicated to the True Cross (Sta. Croce) and its exquisite cruciform chapel, S. Lorenzo, which is generally called the Mausoleum of Galla Placidia. It is unknown which members of the imperial family inhabit the sarcophagi in the chapel, but it is unlikely that Galla herself is there. She died in Rome and her son was murdered shortly thereafter. Her influence on the urban landscape of Ravenna far transcends the buildings with which she is credited. See Kostof, The Orthodox Baptistery of Ravenna, 3: "The empress possessed an unflagging zeal for building." 
II in the last quarter of the fourth century ${ }^{674}$ Ravenna's first bishop, St. Apollinaris, ${ }^{675}$ most likely performed open-air baptisms, both in a nearby river and in the sea. ${ }^{676}$ The simplicity of this type of baptism was actually the common practice of the very early Church, such that Tertullian ( $c a$. 190) felt compelled to offer an apologetic explanation of the rite: “...With such complete simplicity, without display, without any unusual equipment, and (not least) without anything to pay, a man is sent down into the water..." and "...it makes no matter whether one is washed in the sea or in a pond, a river or a fountain, a cistern or a tub (Tertullian, Homily on Baptism, i. 5. 7, and iv.14-15). ${ }^{.677}$ Not only did the early practice emulate the baptism of Christ, but it was also pointedly distinguished from the "pretentious magnificence" ${ }^{, 678}$ of pagan initiation ceremonies.

\footnotetext{
${ }^{674}$ Kostof, The Orthodox Baptistery of Ravenna, 3.

${ }^{675} \mathrm{St}$. Apollinaris $\left(1^{\text {st }} \mathrm{c}\right.$. martyr) is mentioned in Acts as a disciple of Peter, who is credited with establishing Apollinaris as the first bishop of Ravenna (which can therefore claim for itself the enviable sanctity of being an apostolic foundation, an honor that eluded Milan).

${ }^{676}$ Kostof, The Orthodox Baptistery of Ravenna, 5, citing the Passio Sancti Apollinaris.

${ }^{677}$ Wharton, "Ritual and Reconstructed Meaning," 359, citing Tertullian's Homily on Baptism, ed. and transl. Ernest Evans, London, 1964.

${ }^{678}$ Wharton, "Ritual and Reconstructed Meaning," 359 (Tertullian, Homily on Baptism, i. 5. 7.).
} 
However, within the first quarter of the fifth century following the establishment of Ravenna as an imperial capital, Bishop Ursus was able to build a huge five-aisled basilica modeled on S. Tecla in Milan ${ }^{679}$ dedicated to the Anastasis (and predictably called, after the fashion of the time, the Ursiana) ${ }^{680}$ Adjacent to this structure, he added the octagonal baptistery of S. Giovanni in Fonti, not only appropriating the name of the Ambrosian baptistery (which, in fact, is a common name for baptisteries of this type), ${ }^{681}$ but also the octagonal floor plan. Here, Ambrose's plan of niches and

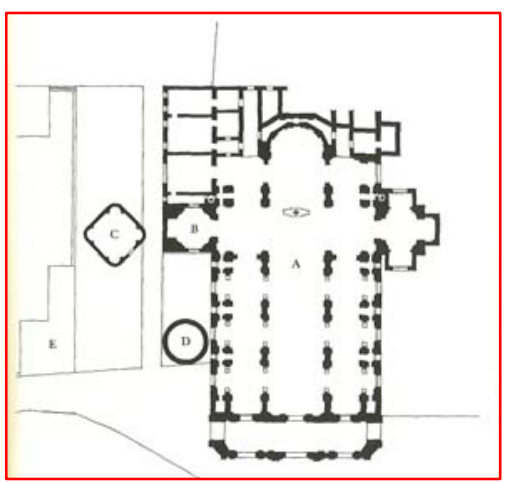

Figure 100: Ravenna, site plan of B. Ursiana and baptistery

flat walls has been reorganized to present

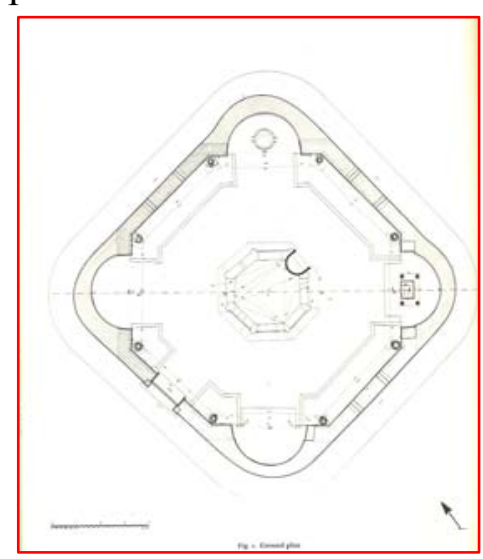

Figure 101: Ravenna, ground plan of the Neonian Baptistery

externally a square building with rounded corners at the ground level. Although there is some scholarly dispute about the death of Bishop Ursus (with some positing as early as 389 and others as late as 426-429), Kostof is inclined to favor the later date for the terminus post quem of the Baptistery, which coincides with the presence of the imperial family. ${ }^{682}$ The Baptistery was subsequently renovated and lavishly decorated by Bishop

\footnotetext{
${ }^{679}$ Wharton, "Ritual and Reconstructed Meaning," 358.

${ }^{680}$ Kostof, The Orthodox Baptistery of Ravenna, 2.

${ }^{681}$ Kostof, The Orthodox Baptistery of Ravenna, 6 . The original baptistery that was attached to the B. Probi in Classis was rededicated as a chuch to the honor of St. Eufemia after Bishop Peter II (494-518) built the B. Petriana which included a new baptistery. St. Eufemia's devotion forms a persistent thread in the history of northern Italian Christianity: Galla Placidia was apparently a Chalcedonian Christian.

${ }^{682}$ Kostof, The Orthodox Baptistery of Ravenna, 12.
} 
Neon. For this we have a reference by the ninth century biographer of Archbishop

Agnellus (557-70), who recorded Neon's inscription for his renovation: ${ }^{63}$

Fontes Ursiana ecclesia pulcerime decoravit. Musiva et auratis tesselis apostolorum imagines et nomina camera circumfinxit, parietes promiscuis lapidibus cinxit. Nomen ipsius lapideis descriptum est helementis.

\section{CEDE VETUS NOMEN, NOVITATI CEDE VETUSTAS. PULCRIUS ECCE NITET RENOVATI GLORIA FONTIS. MAGNANIMUS HUNC NANQUE NEOM [sic] SUMMUSQUE SACERDOS EXQUOLUIT [sic], PULCRO CONPONENS OMNIA CULTU. ${ }^{684}$}

As such, the terminus ante quem of the renovation must be no earlier than the year of Neon's accession, 451. The inscription, very unfortunately, was lost in a subsequent renovation of the baptistery in the sixteenth century; in the eighteenth century it was described as having been over the door. ${ }^{685}$

In addition to his redecoration of the Baptistery, Neon's structural renovations included rebuilding the upper walls of the building and adding a cupola to replace the

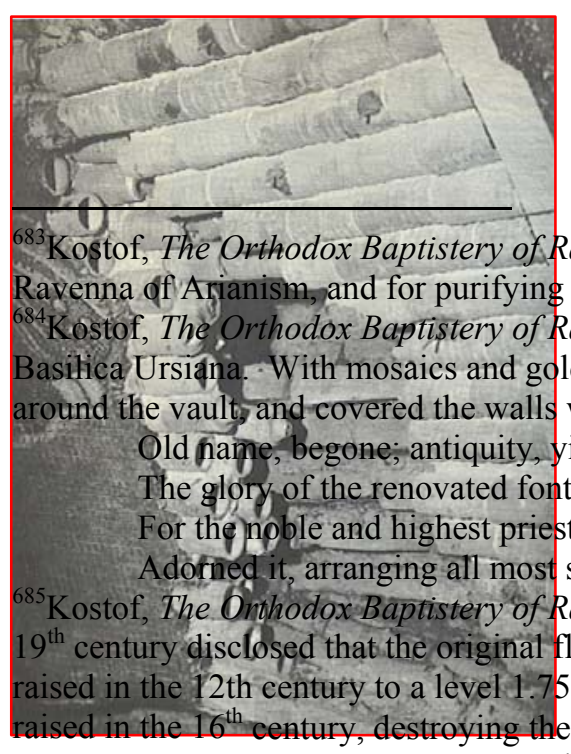

Figure 102: Ravenna, the Neonian Baptistery, hollow tube construction of the cupola $\left(5^{\text {th }} \mathrm{c}\right.$.). although, as Kostof notes, the different levels are not uniform. The original floor of the Mausoleum of Galla Placidia lies $1.43 \mathrm{~m}$. below the present floor, that of the Arian Baptistery (circa 500) is $2 \mathrm{~m}$. lower than the present pavement.

${ }^{686}$ Kostof, The Orthodox Baptistery of Ravenna, 40. original timbered (probably coffered) ${ }^{686}$ roof. Since

the outer walls of the original structure were not 
designed to support the thrust of the weight of a dome, the cupola was constructed of two congruent shells of tubi fitilli (hollow tube construction); the cupola is the only part of the building that is not constructed of brick. ${ }^{677}$ These tubes, which average $0.20 \mathrm{~m}$. long, are joined one to the other and are laid in concentric rings around the central vertical axis of the building. By allowing the outer ring of tubes to secure the inner ring, an elaborate scaffolding of wooden beams was eliminated. ${ }^{688}$ The weight was further reduced by discontinuing the tubular construction $1 \mathrm{~m}$. below the roof, which was then filled with rough pumice from the lava beds of Vesuvius. ${ }^{689}$ Even so, the thrust would still have been significant for walls only about $0.60 \mathrm{~m}$. thick. Neon's architects' solution to this

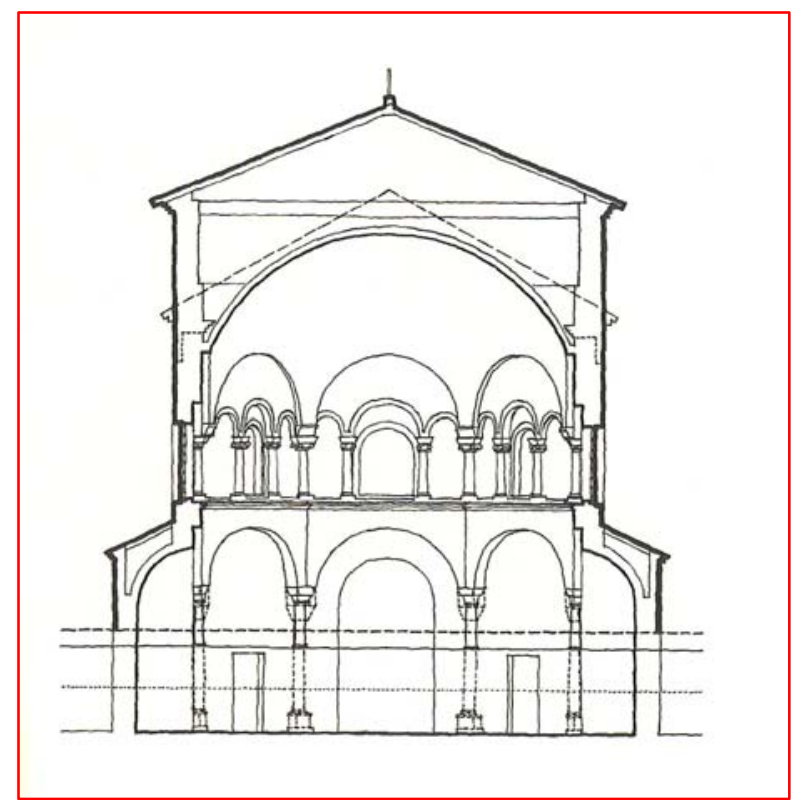

Figure 103: Ravenna, the Neonian Baptistery, isometric plan showing the original roof line and the cupola addition of Bishop Neon $\left(5^{\text {th }}\right.$ c.). problem was ingenious: the cupola was provided with its own supports on the interior in the form of superimposed arcades in the upper zone which transferred the weight to columns in the lower zone and ultimately to the ground. Structurally, the building is actually two independent units: an interior aerial structure, which may be compared to a baldacchino supporting the dome, and

\footnotetext{
${ }^{687}$ Kostof, The Orthodox Baptistery of Ravenna, 32.

${ }^{688}$ Kostof, The Orthodox Baptistery of Ravenna, 32.

${ }^{689}$ Kostof, The Orthodox Baptistery of Ravenna, 33.
} 
an exterior shell of masonry enclosing it all. As Kostof notes, the independence of the interior and exterior structures is a distinctive feature of the Baptistery; in fact, the walls are joined only at certain points where fissures have been filled with mortar. ${ }^{690}$

The building was periodically renovated through the centuries; Kostof notes that until the sixteenth century restoration, beyond a few casual references, there is very little documentation to indicate what renovations were done. ${ }^{691}$ From the fabric of the exterior masonry, very little of which is original to the fifth century structure, ${ }^{692}$ a scar indicates where the structure was freed from its adhesion to a wall of a rectory, which was demolished for the construction of the Cappella del Sacramento. ${ }^{693}$ From the fourteenth century until the seventeenth century, the Baptistery may have been joined to the north doors of the cathedral by a covered portico, but it is clear from the excavations that neither this portico nor any form of ambulatory was ever part of the original structure. ${ }^{694}$ The raising of the floor left the interior columns submerged to a third of their height, disturbing the Neonian proportions of the lower level; the columns were freed of this handicap in $1904 .{ }^{695}$ The original font, which was circular, now forms the foundation for the smaller, octagonal font which was installed in the seventeenth century. ${ }^{696}$ Quite apart from the interior renovations and changes, which will be addressed below, doors were added and removed, the shape of the windows was changed, and the frieze of blind arcading over the windows has been renovated and is characteristically Lombardian. ${ }^{697}$

\footnotetext{
${ }^{690}$ Kostof, The Orthodox Baptistery of Ravenna, 32.

${ }^{691}$ Kostof, The Orthodox Baptistery of Ravenna, 18.

${ }^{692}$ Kostof, The Orthodox Baptistery of Ravenna, 32.

${ }^{693}$ Kostof, The Orthodox Baptistery of Ravenna, 22.

${ }^{694}$ Kostof, The Orthodox Baptistery of Ravenna, 38.

${ }^{695}$ Kostof, The Orthodox Baptistery of Ravenna, 29.

${ }^{696}$ Kostof, The Orthodox Baptistery of Ravenna, 23.

${ }^{697}$ Kostof, The Orthodox Baptistery of Ravenna, 39.
} 
A reconstruction of the original fifth century building must therefore be approached gingerly, with respect to both the original Ursiana building and the Neonian additions of at most fifty years later. Stripped of its reconstruction, the Baptistery of Bishop Ursus was a simple octagon in brick with four corner niches. A line of arched windows at the first level above the niches, one to each wall of the octagon, lit the interior. The height to its timbered roof did not exceed $11.50 \mathrm{~m} .{ }^{698}$ while the ground plan was slightly irregular. On the interior of the structure, the diagonals vary $(11.24 \mathrm{~m}$. and $11.47 \mathrm{~m}$.), as does the length of the interior walls (between $4.48 \mathrm{~m}$ and $4.86 \mathrm{~m}$. ). ${ }^{699}$ This geometric imprecision extends to the verticals of the building, which lean slightly from the southeast to the northwest; there is, actually, no perfect vertical line in the entire structure. $^{700}$ The early font was circular, and constructed of Greek marbles. ${ }^{701}$ The building originally possessed two doors, one on the southwest wall (which is the position of the present single door), and another on the adjacent southeast wall, which gave access to the cathedral. ${ }^{702}$ The niches had tiled roofs, and now rise to a level of $2.30 \mathrm{~m}$ above the present ground level. ${ }^{703}$

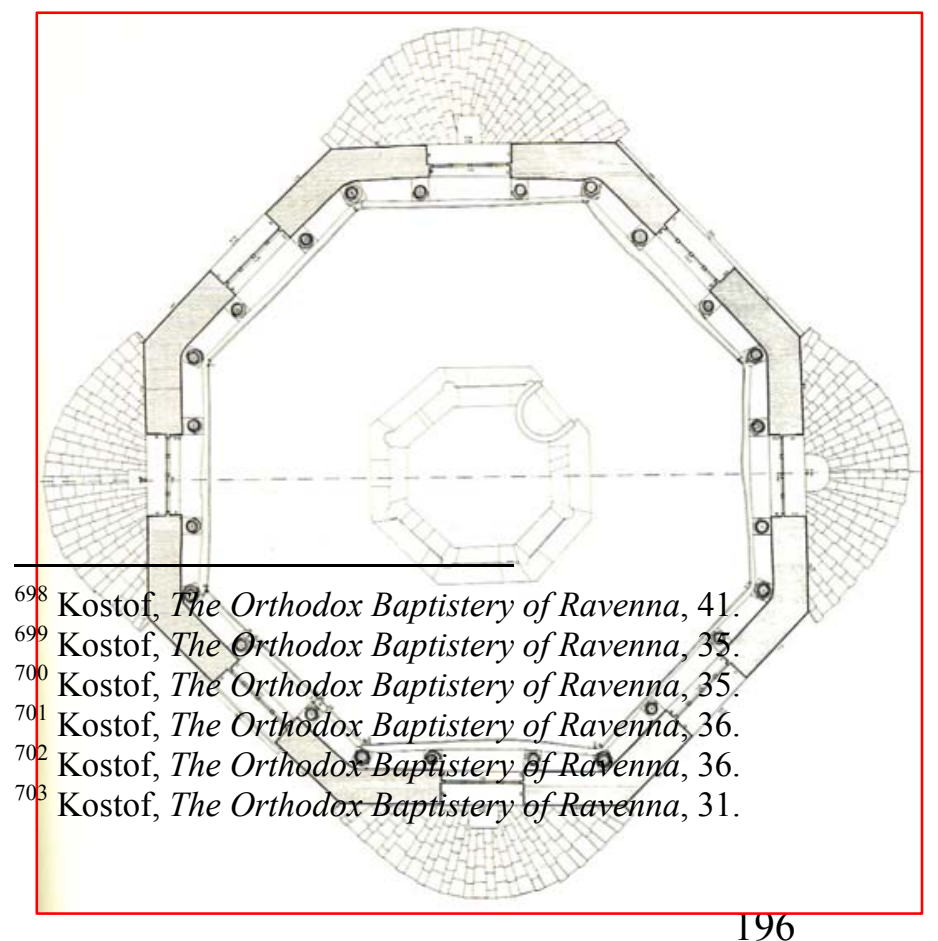

\section{Bishop Neon's}

renovations included the raising of the walls, which now form the octagon above the niches. The addition of the cupola, which is

Figure 104: Ravenna, the Neonian Baptistery, level 2 plan (above the ground niches) $\left(5^{\text {th }} \mathrm{c}\right.$.). 
about $9.60 \mathrm{~m}$. in diameter at its springing line ${ }^{704}$ fits on to the octagon by means of eight segmental pendentives which merge with the curve of the cupola (see the isometric reconstruction, Figure 103). The eight planal segments are enhanced by a frieze of blind arcading which begins two courses down from the cornice of the roof and forms a wide frieze, two double-arched panels per wall. Each panel is $1.40 \mathrm{~m}$. wide and $4.20 \mathrm{~m}$. from the base to the keystone of the arch, sunk $0.10 \mathrm{~m}$. into the masonry. ${ }^{705}$ Although this frieze is a later reconstruction, the inference that Neon added such a frieze seems reasonable, to relieve the new height of the walls. The row of arched windows between the niche level and the frieze is $4.10 \mathrm{~m}$. from the present ground level. ${ }^{706}$

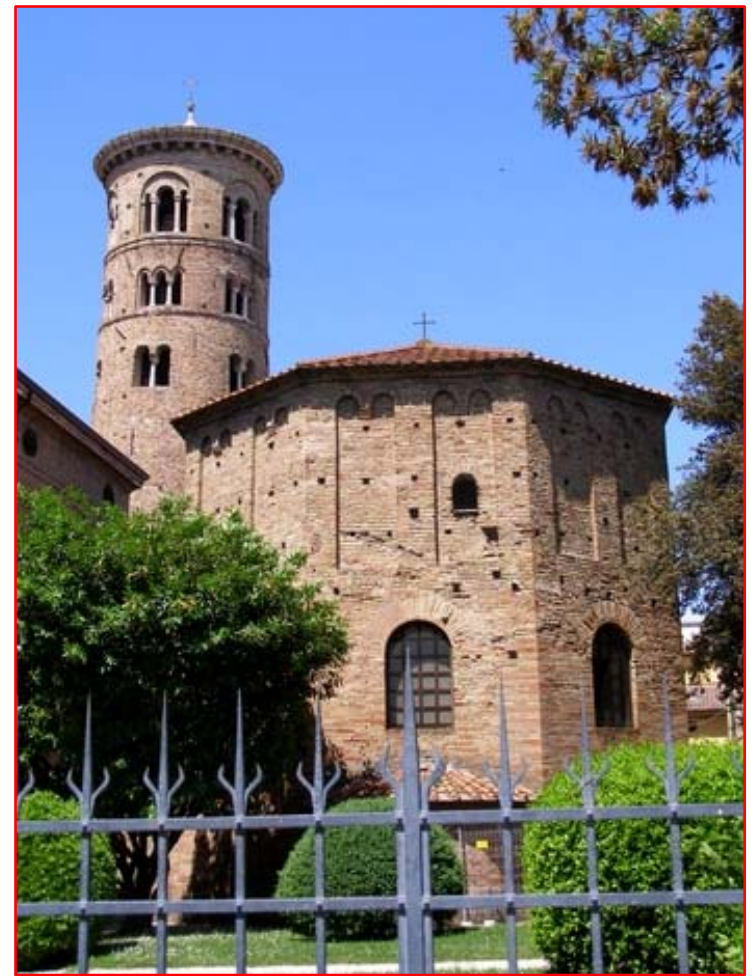

Figure 105: Ravenna, the Neonian Baptistery,

It is difficult to separate the interior architecture of the baldacchino that supports the cupola from the decorative program of the Baptistery, since the one complements the other. The walls of the interior are divided into registers, each of which has its own distinctive architecture and decoration. Kostof's methodology of treating each register as a zone of interest is useful as long as one remembers that, as the eye exterior view $\left(5^{\text {th }} \mathrm{c}\right.$.)

moves from the lower zones to the highest zone of the cupola, the emotional content of the iconography of the decoration also increases in intensity. Additionally, we must infer

\footnotetext{
${ }^{704}$ Kostof, The Orthodox Baptistery of Ravenna, 33.

${ }^{705}$ Kostof, The Orthodox Baptistery of Ravenna, 31.

${ }^{706}$ Kostof, The Orthodox Baptistery of Ravenna, 31.
} 
that the iconography of the decorative program was not only readable to the original viewers, but understandable within the context of their catechesis and instruction as neophyte Christians. ${ }^{707}$

\footnotetext{
${ }^{707}$ The question of the readability of images has formed a persistent dialogue among art historians which must be considered within the context of the intended viewer. Here, at least, we hope to find a firm basis that the instruction of the baptizands would have prepared them sufficiently to enter the circle of understanding of the iconography of the decoration of the Baptistery. Our own problem as late viewers is to recognize that repairs and restorations, some ham-handed, others more considered, have inevitably altered the message (there is a necessary presumption that anachronistic interpretations cannot be considered).
} 


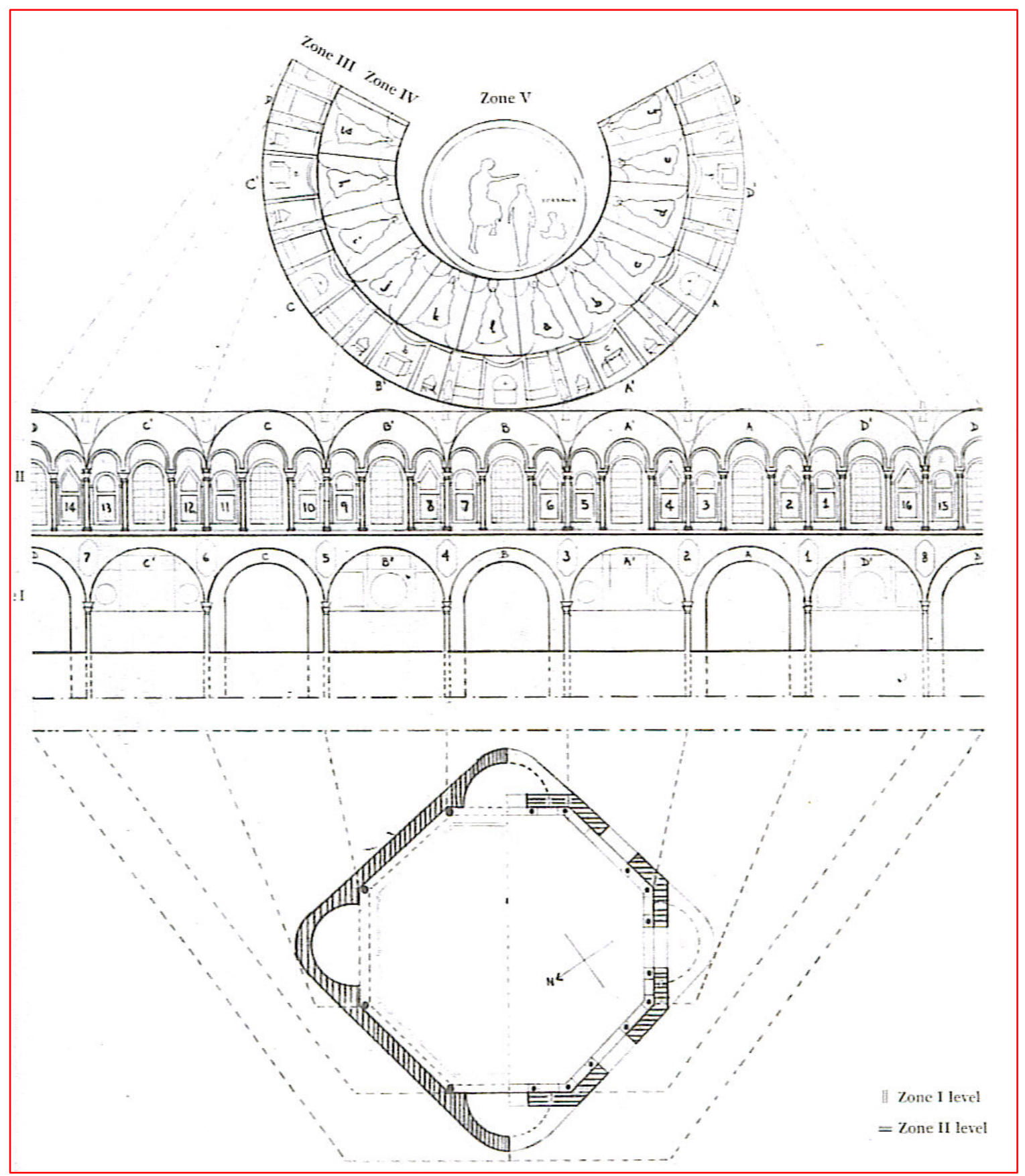

Figure 106: Ravenna, the Neonian Baptistery, schema of the interior decoration $\left(5^{\text {th }} \mathrm{c}.\right)$ (after Kostof)

Within, the cupola rests upon two stories of arcades; the arcade of Zone I (the ground level of entrance and the font) rests on impost blocks placed over the capitals of the eight columns which are placed at the corners of the octagon, while the arcade of Zone II rests on brackets which project over the imposts of the corner columns. The 
columns of the lower zone are a mixed variety, which suggests several possibilities: spolia, the replacements of reconstruction, or design. Two of the columns are Byzantine Corinthian, which Kostof notes were very common in Early Christian buildings of this period. $^{708}$ The other six columns are quite unusual in that they have five volutes instead of the usual four. As such, they present a pentagonal section which appears to have no antecedent; Kostof suggests that they were specifically designed for use in a polygonal building, since if stood in mid- space, they would present a pair of volutes from any viewing angle. ${ }^{709}$ This would be reasonable had they been placed around the font; however, the excavation of that structure does not exhibit any foundations for columns. As such, while the columns may have been designed for a polygonal structure, it is not likely that they were designed for this particular octagonal structure as corner columns. ${ }^{710}$ The brackets of the upper arcade, as they face the interior of the building, are each carved with a cross and a foliage motif. In this zone, twenty-four columns, each about $1.16 \mathrm{~m}$. high (excluding capitals and bases) form the arcade. Only the eight columns at the corners support the cupola; the other sixteen columns form frames for the windows and provide support for the the small triple arcades which are placed within the tympana of the eight main arches of the second zone. We have seen this arrangement before, in the examination of the B. Apostolorum, where the small triple arcade of the transverse arms of the church are nestled in an encompassing superior arch. It is tempting to see this as architectural symbolism for the Nicene mystery of the Trinity, embraced by the overmastering concept of the unity of God.

\footnotetext{
${ }^{708}$ Kostof, The Orthodox Baptistery of Ravenna, 35.

${ }^{709}$ Kostof, The Orthodox Baptistery of Ravenna, 35.

${ }^{710}$ Kostof, The Orthodox Baptistery of Ravenna, 35.
} 
The columns sit on a narrow ledge $0.35 \mathrm{~m}$ wide and small aediculae are placed within the smaller arcades in which stucco reliefs have been constructed. All of the columns except one have Ionic capitals and plain, square bases; the column that differs has no capital but is simply capped by an unadorned pulvin block. The cupola springs from the second arcade, constructed (as has been noted) as merged pendentives and is decorated with three concentric registers of mosaic (Zones III, IV, and V of Figure 106).

The baptizands entered the Baptistery in the hours just before dawn at the end of the Vigil of Holy Saturday. "The Holy of holies was unbarred to thee, thou didst enter the shrine of regeneration." 711 The building was lit by eight lamps which hung from the lower section of the cupola; ${ }^{712}$ there may also have been portable candelabra. Entering from the southwest and facing east, the first view of Zone I would have fixed on the font, the central piece of liturgical equipment. The walls of this zone were reveted in opus sectile, a pattern of marble veneers, described by Agnellus as porphyry disks framed with pink African marbles and majolica, alternating with green rectangular slabs flanked by porphyry disks. ${ }^{713}$ As the eye travels around the room, it is arrested by the niches of the small apses which have mosaic inscriptions above them. The location of these inscriptions, and the nature of the text, is designed to complement the liturgy.

At the beginning of the ceremony, the neophyte was turned to the west to renounce Satan and all his works. As he faced west, the texts that confronted him were Matthew 14: 20-32 (“And when Peter was come down out of the ship, he walked on

\footnotetext{
${ }^{711}$ Ambrose, De mysteriis, ii. 5.

${ }^{712}$ Kostof, The Orthodox Baptistery of Ravenna, 33: this is a reasonable inference to explain the eight holes which are filled with stucco that rim the lower section of the cupola, and which are on the same axis as the windows.

${ }^{713}$ Kostof, The Orthodox Baptistery of Ravenna, 58: the marbles that we see today date from the 1890s and can only simulate Agnellus' description.
} 
water, to go to Jesus...And immediately, Jesus stretched out his hand, and caught him... and when they were come into the ship, the wind ceased."') ${ }^{714}$ and Psalms 23:2 ("He maketh me to lie down in green pastures: he leadeth me beside the still waters"). ${ }^{715}$ With Christ the protector leading the way to the peace of still waters, these reassuring verses gave heart to the neophyte as he made his renunciation, leaving the stormy sea of his pre-Christian life. The metaphor of the storm-tossed sailor was a familiar image of exegesis from very early Christian iconography; both Noah and Jonah appear in catacomb art and on early sarcophagi. ${ }^{716}$ Just as familiar was the image of the Good Shepherd, which begins Psalm 23 (“The Lord is my shepherd, I shall not want"), for Christ had described himself as such. ${ }^{717}$

\footnotetext{
${ }^{714}$ Kostof, The Orthodox Baptistery of Ravenna, 59, ihs AMBULAS SUPER MARE PETRO MERGENTI MANUM CAPIT ET IUBENTE DOMNO VENTUS CESSAVIT.

${ }^{715}$ Kostof, The Orthodox Baptistery of Ravenna, 61, IN LOCUM PASCUAE IBI ME CONLOCAVIT SUPER AQUA REFECTIONIS EDOCAVIT ME.

${ }^{716}$ Lowden, Early Christian and Byzantine Art, 26, 27.

${ }^{717}$ Lowden, Early Christian and Byzantine Art, 21: John 10:11.
} 
As the baptizand turned to the east to make his pledge of adhesion to Christ, the apse inscriptions were more immediately topical, both referencing the efficacy of baptism in washing the stain of sin away. To the east is the text of John 13: 4-5 which recalls the pedilavium that was so determinedly a sacramental aspect of the Ambrosian rite ("he

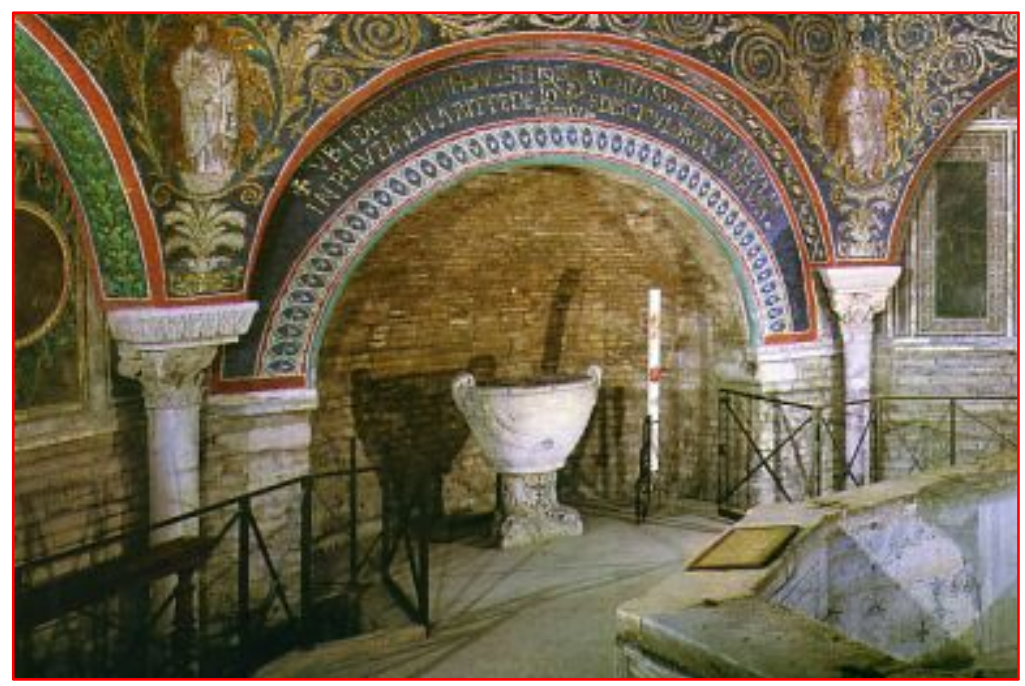

Figure 107: Ravenna, the Neonian Baptistery, inscripted niche $\left(5^{\text {th }} \mathrm{c}.\right)$ riseth from supper and laid aside his garments; and took a towel, and girded himself. After that he poureth water into a basin and began to wash the disciples' feet"). ${ }^{718}$ Finally, as the eye travels to the last text of the south niche, the neophyte is confronted by a second psalm (32:1-2) which reinforces the laving power of baptism ("blessed is he whose transgression is forgiven, whose sin is covered. Blessed is the man unto whom the Lord imputeth not iniquity"). ${ }^{719}$ On the soffits of the lower arcade above the inscripted niches and marble revetments, deep blue mosaic panels are entwined with golden rinceaux which are punctuated above the eight columns by medallions of gold mosaic in which float nameless individuals in white robes. Four of these men are old and carry books; the other four are young and carry scrolls. There is no way of identifying whom they represent; the most reasonable explanation is that the older men represent the major prophets of the Old Testament who

\footnotetext{
${ }^{718}$ Kostof, The Orthodox Baptistery of Ravenna, 60, UBI DEPOSUIT ihs VESTIMENTA SUA ET MIESIT AQUAM IN PELVEM ET LABIT PEDES DISCIPULORUM SUORUM.

${ }^{719}$ Kostof, The Orthodox Baptistery of Ravenna, 59, BEATI QUORUM REMIISSAE SUNT INIQUITATES ET QUORUM TECTA SUNT PECCATA BEATUS VIR CUI NON IMPUTAVIT DOMINUS PECCATUM.
} 
foretold the coming of Christ, while the younger men represent either prophets of the New Testament or the writers of the canonical gospels, the authors of the revelation of Christ. ${ }^{720}$ Here, the acanthus leaves which form the frame of their medallions is the source of the golden vine. This is a familiar image of everlasting life in Roman iconography which came to represent Christ, who termed himself " "the true vine," and likened the kingdom of heaven to a vineyard. ${ }^{721}$

The arcade of Zone II forms an intermediary zone of stucco relief. Here again,

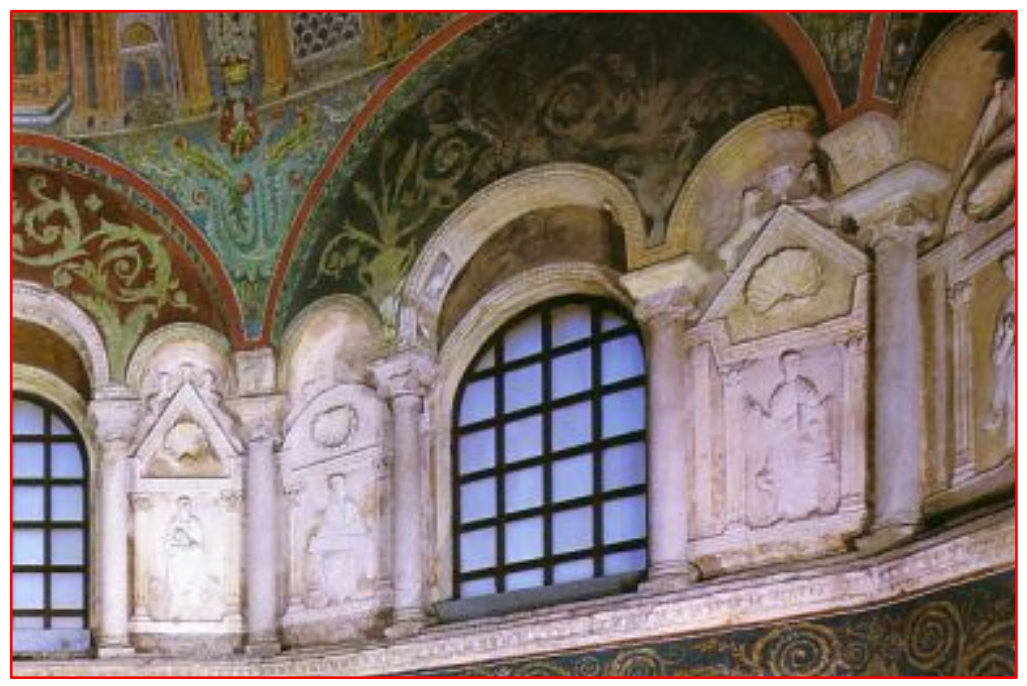

Figure 108: Ravenna, the Neonian Baptistery, stucco relief $\left(5^{\text {th }} \mathrm{c}.\right)$ framed by their little aediculae, sixteen nameless prophets cast their view upon the neophytes. Some of these individuals hold books, some hold scrolls, all are dressed in the pallium, which, flying out away from them as though blown by the wind, is marked with the Latin letter "Z." These prophets (so defined by the books they carry), however, are uniformly young, beardless, with ringlets about their heads. The most interesting thing about them is their faces: the upturned, convex mouths and the staring eyes (formed by the deep drilling of the irises) are most reminiscent of Roman masks.

\footnotetext{
${ }^{720}$ Kostof, The Orthodox Baptistery of Ravenna, 62: in which case, as Kostof notes, it would be more logical if the Old Testament prophets carried the scrolls, and the New Testament prophets carried the books.

${ }^{721}$ Lowden, Early Christian and Byzantine Art, 19: John 15:1.
} 


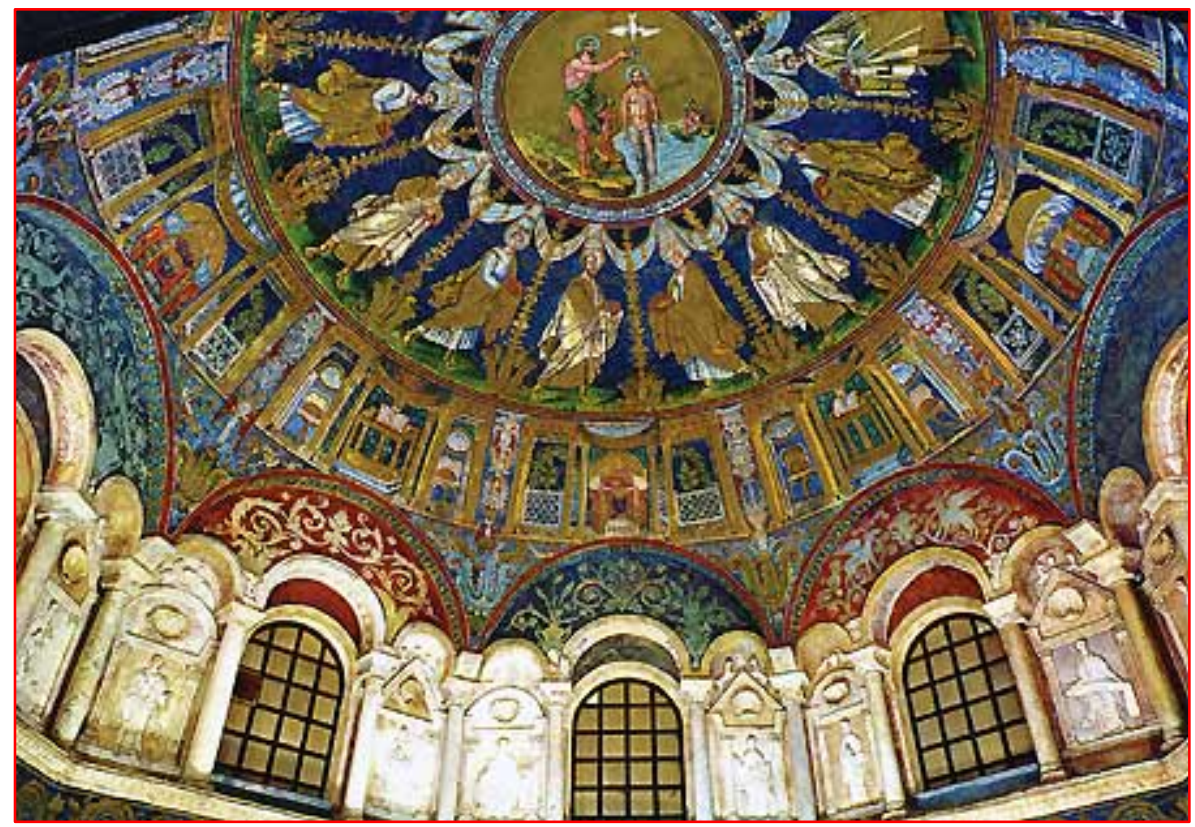

Figure 109: Ravenna, the Neonian Batistery, the arcade of Zone II $\left(5^{\text {th }} \mathrm{c}.\right)$.

Originally, the stucco decorations were painted in different colors. Periodic restorations to recreate this polychromy have been unsuccessful, and a monochrome approach has been adopted as the least objectionable.

The lunettes above the windows which link the aediculae of the prophets are decorated with vines and pairs of opposing heraldic animals: goats, doves, deer, seahorses, eagles, lions, sheep, roebucks, peacocks, hares, cocks and pheasants. Of this assortment, two groups are repeated, the deer (hart) and the peacock. The hart has been traditionally associated with baptism, based upon Psalm 42: "As the hart panteth after the water brooks, so panteth my soul after Thee, O God.” Kostof describes the baptistery at Salona with a mosaic panel which shows two harts drinking from a vase with the verse inscribed above them: SICUT GERVUS DESIDERAT AD FONTES AQUARUM ITA DESIDERAT ANIMA MEA AD TE DEUS. ${ }^{722}$ The peacock, with less textual

\footnotetext{
${ }^{722}$ Kostof, The Orthodox Baptistery of Ravenna, 66.
} 
confirmation, is generally viewed as a symbol of eternal life and incorruptibility in Early Christian iconography.

Above four of the aediculae are reliefs of biblical and dogmatic scenes. These include Jonah and a pair of symmetrically opposed whales (a much beloved story that resonated with early Christians in catacomb, sarcophagus, and small objects art as a prefiguring of Christ's death and resurrection), and Daniel in the lions' den. Again, the lions are shown in a heraldic manner with curling tails and very sharp teeth facing the figure of Daniel, who wears a medallion embossed with the Xi-Rho monogram of Christ. The motif of Daniel was also a very popular Early Christian theme that occurs in catacomb art, perhaps deriving from third century Jewish liturgy with the prayer, "Deliver, Lord, the soul of thy servant as thou hast delivered Noah from the deluge, Daniel from the lions' den...,723

Bracketed by these two biblical scenes, are two reliefs of dogmatic relevance. One shows a youthful (unbearded) Christ, the ringlets of his hair falling to his shoulders, with the Cross upon one shoulder and an open book in his hand treading on two mythic creatures. He wears a Roman soldier's armor, with a mantle thrown over his shoulder and military boots, while the inscription on the book is EGO SUM VIA VERITAS ET VITA. ${ }^{724}$ The pertinent texts are Psalms 91:13 ("Thou shalt tread upon the lion and adder; the young lion and the dragon shalt thou trample under feet") and Luke 10:19 ("Behold, I give unto you power to tread on serpents and scorpions, and over all the power of the enemy"). Kostof notes that not only is this theme unusual and uncommon in Early Christian iconography, but the depiction of Christ in military garb also has few

\footnotetext{
${ }^{723}$ Kostof, The Orthodox Baptistery of Ravenna, 71.

${ }^{724}$ John 14: 6, "Jesus saith unto him, I am the way and the truth and the life; no one cometh to the Father but by me."
} 
examples, being unknown in Italy, with the exception of Ravennate examples. ${ }^{725} \mathrm{He}$ believes that it originated in Egypt and was brought to Ravenna. ${ }^{726}$ However, as we have seen, it has a distinctly Ambrosian reference, where it was linked to the pedilavium, with the laving of the foot that was first poisoned by the serpent in the Garden of Eden. Additionally, Christ's text must refer to the bishop's role as the only gatekeeper to full participation as a Christian, through the rite of baptism and the conferring of confirmation, and His depiction as a Roman soldier reiterates the bishop's standing as a civil as well as a religious leader, who often, like Ambrose, came from the ranks of imperial service.

The other relief shows the youthful Christ seated on a throne, looking to his right where St. Peter extends his arms to receive the Law, while St. Paul raises his hand in the traditional gesture of one about to speak. This version of the Traditio legis theme is peculiarly Ravennate: the usual rendering has St. Paul on the right receiving the Law, while St. Peter stands behind Christ. ${ }^{727}$ It is possible that this rendition may express some of the tension that the Ravennate see felt as an imperial capital that remained, unlike Milan, a suffragan of Rome, rather than a primatial see in its own right. However, the position of these two dogmatic reliefs on the west side of the Baptistery, where they formed an apposite pair, must have had liturgical significance, since they were viewed during the Apotaxis (renunciation of Satan). In renouncing his old life, the way of sin and death, the neophyte agreed to live his life as a Christian, governed by the Law of Christ.

\footnotetext{
${ }^{725}$ Kostof, The Orthodox Baptistery of Ravenna, 67. A mosaic in the Archepiscopal Chapel of Ravenna shows Christ treading on the lion and the adder and in Sant'Apollinare Nuovo; a mosaic panel in the gateway of Theodoric's palace reiterates the scene, although there Christ is flanked by two other figures. Agnellus noted that a mosaic in the B. Santa Croce of Galla Placidia (lost) also showed this scene.

${ }^{726}$ Kostof, The Orthodox Baptistery of Ravenna, 68.

${ }^{727}$ Kostof, The Orthodox Baptistery of Ravenna, 70.
} 
The architecture of Zone II, with its combination of aediculae, columns, and silent, viewing figures has a peculiar, stage-like quality, reminiscent of the scaenae frons of Roman theatres. ${ }^{728}$ The ready-made audience of prophets represents the divine witnesses of the action of the rites, which are taking place within the staging of the arena of the baptizands' trial, and recall the Ambrosian admonition that their affirmation would be recorded for the ages. ${ }^{729}$ And it is fitting that it is the prophets who should be depicted, whose books formed the special textual source of the Ambrosian exegesis during the Octave of Easter.

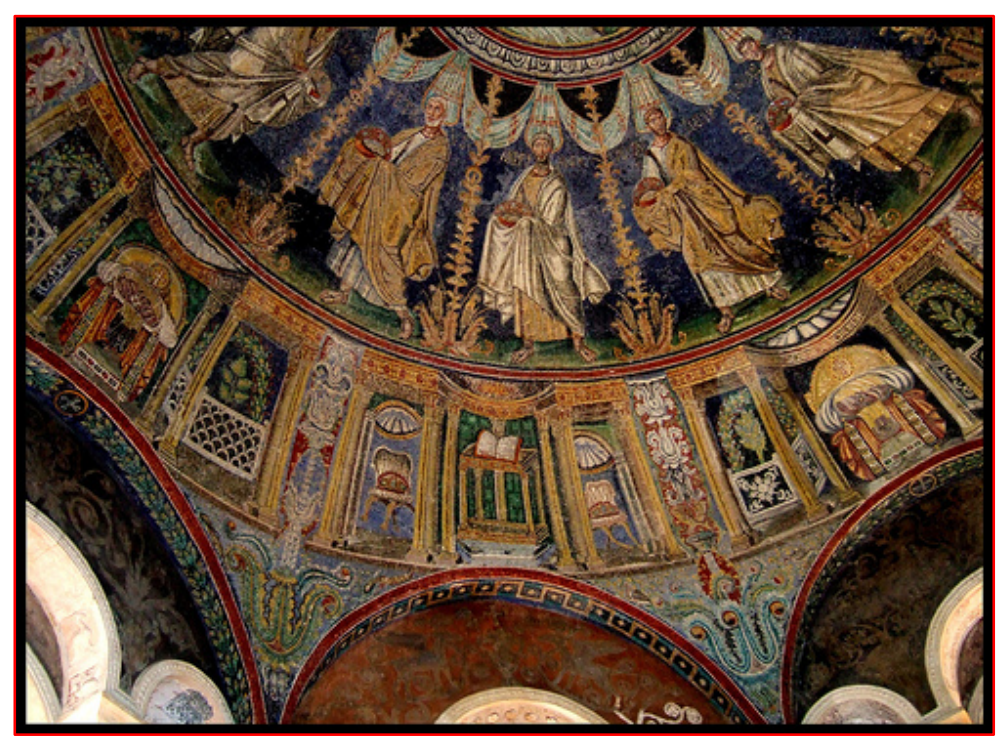

Figure 110: Ravenna, the Neonian Baptistery, Zones III and IV of the mosaic registers of the cupola $\left(5^{\text {th }} \mathrm{c}\right.$.
Zone III initiates

the springing of the dome

and the mosaic decoration

of that element which

comprises three separate

registers. This zone, which

is narrow relative to Zone

IV, must be regarded as

mysterious to modern viewers, and we can only speculate on its reading for the baptizands who viewed it. Here, eight panels are divided by standing candelabra formed by acanthus plants which appear to sprout from the spandrels of the arches of the arcade of Zone II. The panels alternate; four of the panels show altars upon which the four open canonical gospels rest (identified

\footnotetext{
${ }^{728}$ Kostof, The Orthodox Baptistery of Ravenna, 74, for example, the Large Theatre of Pompeii.

${ }^{729}$ See note 423 .
} 
by their inscriptions). On either side of the altars are small thrones, surmounted by a

conch shell. The alternating panels are magnificent thrones, richly

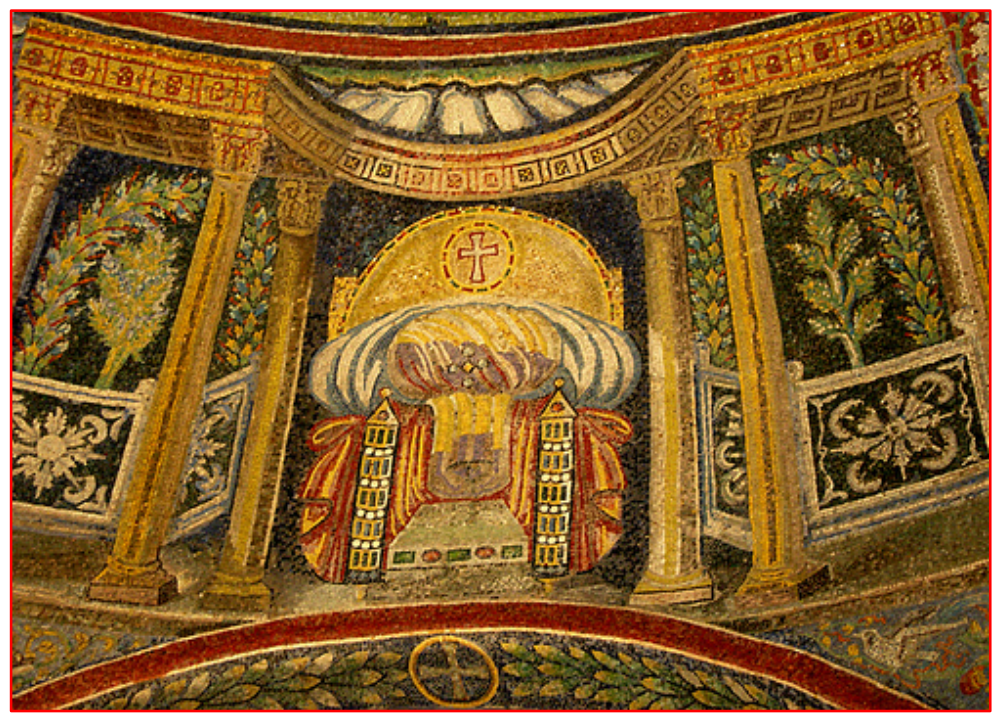

draped and bejeweled,

which are surmounted by a

white cross which shines in

an aureole. In front of the

thrones are footstools, also

gem-studded, and on either

side are smaller panels with

Figure 111: Ravenna, the Neonian Baptistery, Zone III, throne panel ( $5^{\text {th }}$ c.)

foliage and a parapet or screen. All of the large and small panels are framed with mosaic representations of columns supporting lintels.

While the altars bearing the canonical gospels appear to be fairly logical references to the sources of Christ's historical and theological presence, ${ }^{730}$ which the neophyte would have studied prior to his initiation, the combination of simple and elaborate thrones has provoked a number of interpretations, almost all of which have been either anachronistic ${ }^{731}$ or are so restricted by their references as to have rendered them unintelligible to the intended viewer.

\footnotetext{
${ }^{730}$ Kostof, The Orthodox Baptistery of Ravenna, 81, citing P. Underwood, Dunbarton Oaks Papers, 5, who notes that the gospels are also associated with the four rivers of Paradise. Their relationship to baptism is found in St. Cyprian's exegesis: "Ecclesia, setting forth the likeness of paradise, includes within her walls fruit-bearing trees [which] she waters with four rivers, that is with the four gospels wherewith, by a celestial inundation, she bestows the grace of saving baptism. (Epistolae, lxxiii. 10)"

${ }^{731}$ Kostof, The Orthodox Baptistery of Ravenna, 80: Barbier de Montault (late $19^{\text {th }}$ century) suggested that the thrones represented the second coming of Christ foretold in Psalm 89: "Justice and judgement are the
} 
The interpretation that the panels of the altars with the flanking, small thrones represented a cross section of the sanctuary of the church was first suggested by J. P. Richter, noting that in Milan, following the lead of Jerusalem, the thrones of the bishop and emperor stood on either side of the altar, ${ }^{732}$ and this interpretation has been largely validated in the scholarship. Grabar has extended the specificity of the Jerusalem/Milanese practice to the larger theme of the celestial Jerusalem. ${ }^{733}$ This Kostof has further elaborated by positing that the smaller thrones represent the Church on earth, while the large thrones represent the celestial Church, the heavenly domus Dei, of which the Church on earth is an imperfect facsimile. ${ }^{734}$ The screen-like structures that frame the large thrones must, therefore, represent the screens of the cancellus that shielded the sanctuary.

This interpretation, which I believe to be completely intelligible, can be extended liturgically and symbolically. The images of the altars and small thrones represent the sanctuary of the earthly structure of the ecclesia, which was the immediate destination of the baptizands: their full participation in the Eucharist. This would have been entirely recognizable to the initiates from their attendance in church as catechumens. And it was their participation in the Eucharist that would permit them to approach the throne of Christ's presence at His heavenly altar, symbolized by the large thrones surmounted by the Cross, which is Christ. This then, is the Gateway, the entrance to a new life on earth as professed Christians, and the guarantee of life eternal. Time and space are infinitely

habitation of thy throne; mercy and truth shall go before thy face," a theme which, though common in late Byzantine thought and art, was as yet undeveloped in the Early Christian period.

${ }^{732}$ Kostof, The Orthodox Baptistery of Ravenna, 81.

${ }^{733}$ Kostof, The Orthodox Baptistery of Ravenna, 82.

${ }^{734}$ Kostof, The Orthodox Baptistery of Ravenna, 82: De Montault anticipated the extension of this interpretation by suggesting that the large thrones represented the great sees (Jerusalem, Constantinople, Alexandria, and Rome), while the smaller thrones represented the lesser sees. 
compressed to that period of the rite of passage which is the baptizands' initiation, guided and mediated by their earthly bishop. Even more interesting is the inference that Bishop Neon, having appropriated the Milanese liturgical arrangement of the church's sanctuary for representation in this zone, had very likely continued to use the Milanese liturgy, in spite of his governance by Rome, and that we see it in these images. Given the other references to the Ambrosian rite of baptism, the reliefs of the pedilavium and Christ treading on the adder and the dragon, I don't think the inference is unwarranted.

Zone IV introduces the neophyte viewer to the twelve Apostles, whose movement and intensity dramatically increase the pace and rhythm of the ascending spiral. The Apostles are shown robed in dalmatics and palliums, which are banded by magisterial stripes and alternate in color between gold and white. They wear sandals and are striding purposefully (their draperies swirl about them) in groups of six, one group led by 


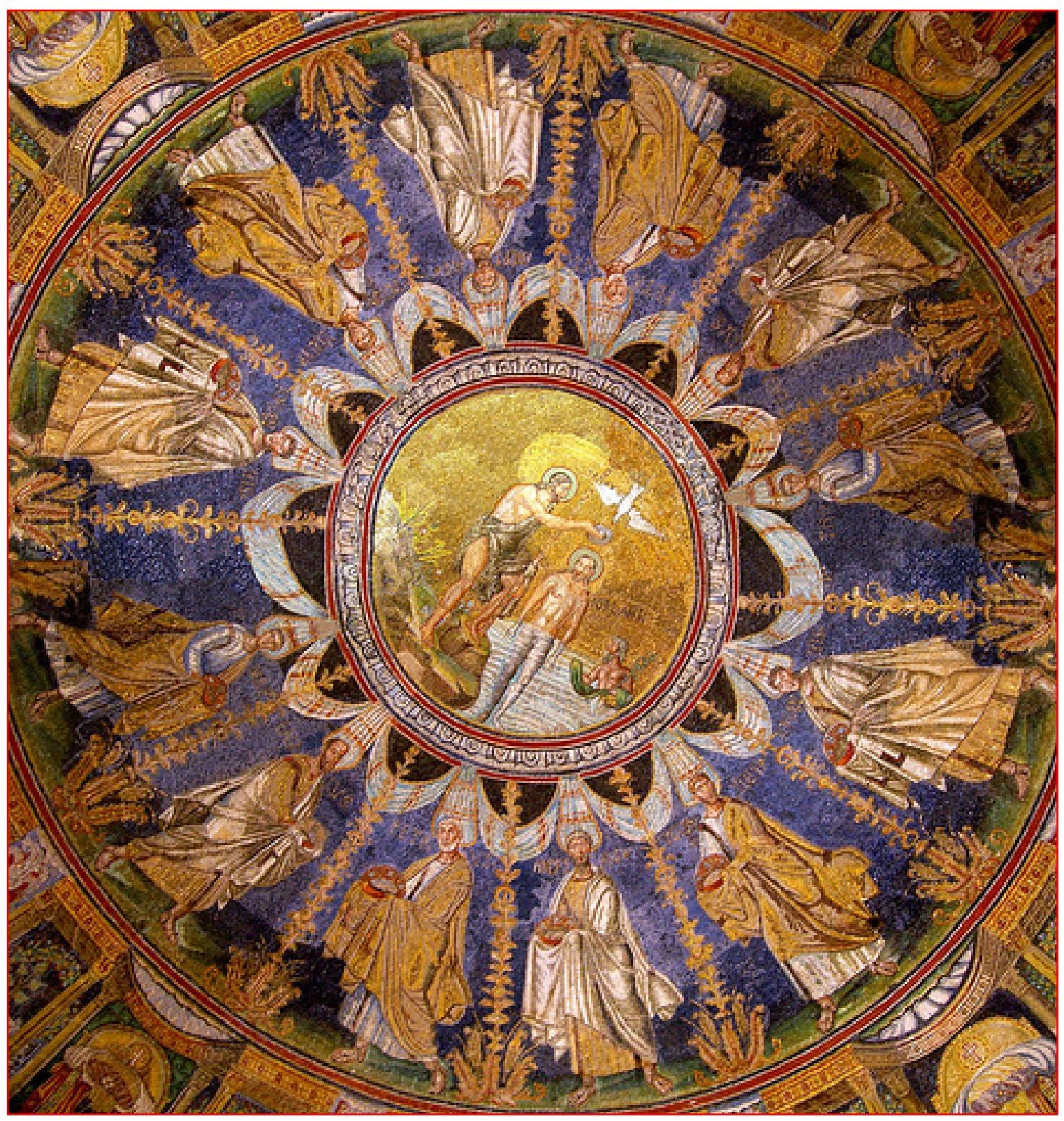

Figure 112: Ravenna, the Neonian Baptistery, Zone IV and V, the Apostles of Christ and the Baptism of Christ $\left(5^{\text {th }} \mathrm{c}\right.$. $)$

St. Peter and the other led by St. Paul.

The Apostles are identified by name; Judas Zelotes replaces Judas Iscariot, and Paul replaces Thaddeus. The figures and faces are skillfully rendered and the portraits of 
each figure are individualized. Although St. Peter and St. Paul are represented in a manner that had become a part of a traditional iconographic canon, ${ }^{735}$ it is less easy

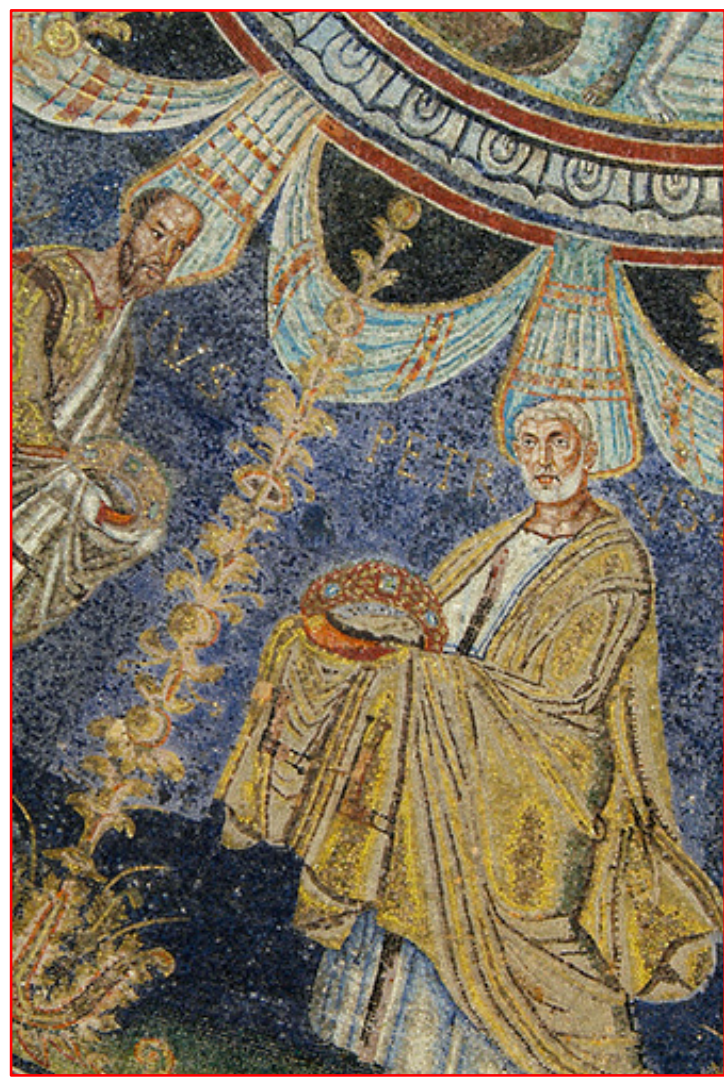

Figure 113: Ravenna, the Neonian Baptistery, Sts. to identify the sources of the other Apostles. Their portraits suggest that the artist may have been using live models to draw on different facial characteristics to individualize his figures. ${ }^{736}$ The vitality of the Apostles' faces, their evident movement within their zone, and the disinclination of the artist to convert them into abstractions have made these mosaic representations unique among early fifth century mosaics, dynamic and vivid.

\section{Each of the Apostles is carrying a} Peter and Paul, Zone IV $\left(5^{\text {th }}\right.$ c.)

crown, which may represent the crown of martyrdom, but may also be a liturgical

reference to the anointing with chrism which then placed the baptized Christian within that elect circle of a royal priesthood. ${ }^{737}$ Indeed, the manner in which the Apostles carry their crowns suggest that they are prepared to offer them (Figure 113). If this is so, then the offering of the crowns again reinforces the role of the bishop, to whom the liturgical act of confirmation is restricted, and who is the spiritual lineal descendant of the Apostles.

\footnotetext{
${ }^{735}$ Kostof, The Orthodox Baptistery of Ravenna, 84. St. Peter took on the characteristics of the Capitoline Brutus, white-haired and beared with a squared facial structure. Paul was generally shown dark-haired and bearded, balding, with a long face and aquiline nose.

${ }^{736}$ Kostof, The Orthodox Baptistery of Ravenna, 84.

${ }^{737}$ De mysteriis 29-30: "in regnum dei at sacerdotium."
} 
Each Apostle is separated from his neighbor by plant-candelabra which grow from an acanthus base, as in Zone III. The use of candles in the baptismal rite was not only necessary, since the ceremony took place at night, but it also had liturgical significance. In John 8:12, Jesus suddenly announces to his listeners, "I am the light of the world. Whoever follows me will never walk in darkness, but will have the light of life." The expression, "receiving light," ${ }^{, 738}$ had become a metaphor for being baptized. Gregory of Nazianzus connected the lights of baptism to the parable of the bridesmaids: "The lamps which you will light symbolize the torchlight in the next world, in which our shining, virgin souls will meet the bridegroom with the shining light of faith." ${ }^{, 739}$ As each newly baptized Christian left the baptistery, he carried a candle to light his way to the waiting church and the baptismal candle continues to be a special prop of the current

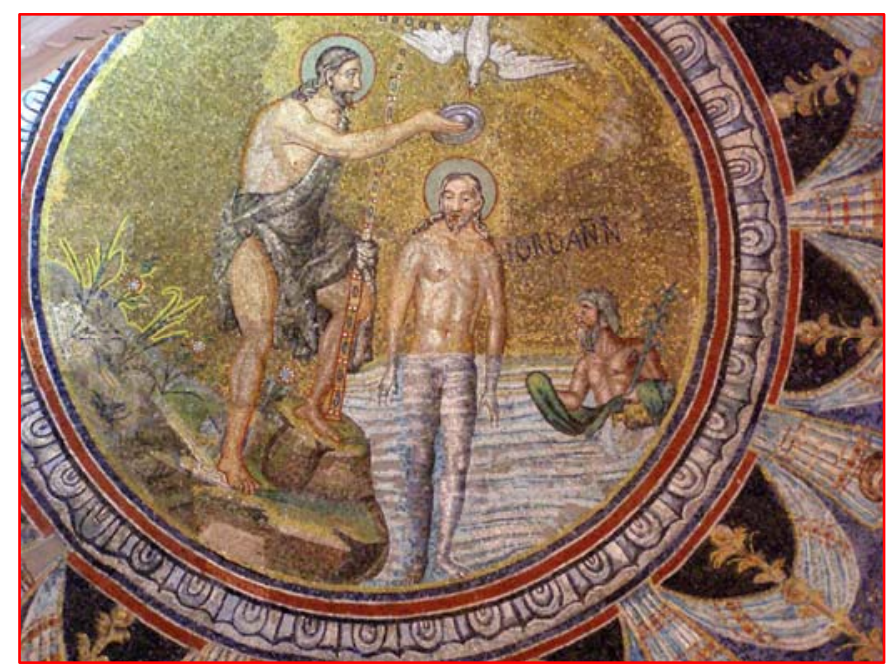

Figure 114: Ravenna, the Neonian Baptistery, Zone V, the Baptism of Christ $\left(5^{\text {th }} \mathrm{c}\right.$.) liturgy.

The crown of the dome,

Zone $\mathrm{V}$, is a circular medallion

depicting Christ's baptism by His

cousin John. Christ is shown

nude, half-submerged in the

Jordan River, which is identified

by an inscription and personified

by the figure of a river god.

Unlike the river god of the Arian Baptistery, this figure does not flee, but appears to be ready to assist the Precursor if need be, and certainly to act as a witness. John is shown

\footnotetext{
${ }^{738}$ Hebrews 6:14, 10:32.

739 Oratio, 40, 46.
} 
dressed in the traditional exomis of animal skins; in his left hand he holds a large crux gemmata. With his right hand he baptizes the Lord with what appears to be a patera, a bowl that was used to pour water over the head of the baptizand. We cannot attach too much liturgical significance to this, since the use of the patera as a baptismal prop was unknown before the eigth century. ${ }^{740}$ As such, we must assume that this object is an interpolation of a later reconstruction of the mosaic.

Both individuals in the mosaic are shown bearded. In spite of the fact that only six months separated the men in age (Luke 1:24-27), the usual convention was to show St. John as a bearded prophet, and Christ as a young, beardless man. As such, it is very likely that here, too, a restorer has added to the original concept. Both figures have haloes, and their bodies are skillfully modeled to show the musculature. This is an important aspect of the painting, since this was an event that took place in Christ's earthly life. There is nothing liminal about these figures.

The presence of the descending dove, which signifies the Holy Spirit, is also important, theologically and liturgically. Matthew recorded: "And Jesus, when he was baptized, went up straightway out of the water: and, lo, the heavens were opened unto him, and he saw the Spirit of God descending like a dove and coming down on him. And a voice spoke from heaven, 'This is my Beloved Son, in whom I am well-pleased."’741 Theologically, the Trinity is revealed in this moment: God the Father's voice is heard, Jesus stands naked, identified by God the Father as God the Son, and God the Holy Spirit descends to validate the revelation. In this one sublime moment, heaven and earth overlap. We can see this melding in the background of the mosaic: behind Christ is the

\footnotetext{
740 Kostof, The Orthodox Baptistery of Ravenna, 86.

${ }^{741}$ Matthew 3:16-17.
} 
golden atmosphere of heaven, while behind St. John, the golden tesserae give way to the more subtly colored glass of the earthly atmosphere, and trees intrude. Liturgically, Christ demonstrates how the rite will be performed. As God, Christ has no imperfections, no need for baptism. He chooses to be baptized to bind his followers to himself and to each other. He goes into the water, he is washed, he receives the Holy Spirit, and he comes up out of the water. Ambrose alludes both to the pattern and the meaning of this moment:

And thou hast read that, when our Lord Jesus Christ was giving the pattern of baptism, he came to John...Therefore, if baptism is for our sake, a pattern has been established for us, the pattern of our faith has been set forth. Christ descended, John stood by baptizing, and, lo, the Holy Ghost descended as a dove...The Holy Spirit...descended from heaven, not in the reality of a dove, but in the likeness of a dove. Therefore, John saw and believed. ${ }^{742}$

Ambrose, De sacramentis, I, v. 15-17.

No single rite of the Church was more closely linked to Ambrose of Milan than baptism. As bishop and defender of the Milanese liturgy, he defined himself liturgically with the rites of initiation, by his writing and by the care with which he invested the catechesis of his initiates. Architecturally, the Neonian Baptistery represents a structural epitome of the liturgy of the Ambrosian ceremonies of initiation. From without, the flat, planar expanses of the walls of the symbolic octagon give no indication of what will occur within. That secret will be shown only to those who have made the commitment to the requirements of Christian life. Having undergone self-abnegation, scrutiny, exorcism, and instruction, in the early dawn of their long Vigil of Easter, they entered a building separated from the body of the church which was their gateway to full participation in what Christ had indicated was the Body of His Church. Within the richly decorated,

${ }^{742}$ The emphasis is not mine. 
privileged interior, from the first encircling columns of the lower zone, they experienced a steady acceleration of emotion and understanding, enhanced by text and images. The rhythm of the columns of the second zone sped them upward in a spiral through the watching prophets, the mysterious thrones, the dynamic Apostles, until finally, at the moment of their immersion in the font, they were linked, architecturally, in the direct line of the vertical axis from the font to the crown of the dome. For one brief, eternally and unequivocally epochal moment, they were spiritually and emotionally joined by their immersion and baptism to Christ temporal and eternal. 


\section{CHAPTER VII}

\section{CONCLUSION}

Early in 397, Ambrose, disheartened by the loss of his friend and bishop, Eventius of Pavia, and wearied by the trip he made to replace him, informed his clergy that he would be with them only until Easter that year, for he had beseeched God "that he might be freed earlier of this place.",743 As the day of the great vigil of Easter dawned, Ambrose of Milan lay dying, true to his word. Stilicho, general and the regent of Emperor Honorius waited fretfully without, having summoned the bishops of northern Italy, ${ }^{74}$ who now clustered anxiously around their archbishop with the resident clergy. Speaking in hushed tones, they wondered who would replace him, but the bishop, as though he were conferring with someone, murmured the name of Simplicianus three times, saying "He is an old man, but a good one." 745 In the early hours of the dawn of Easter, Ambrose stretched out his arms in the manner in which he had been accustomed to perform the liturgy of the Eucharist, and prayed his last. His body was born to the cathedral, all Milan in procession behind him, Christians, pagans, and Jews, with the newly baptized leading the way in their shining white garments. ${ }^{746}$ At the burial, mass hysteria reigned, as the crowds fought their way to touch their handkerchiefs on the corpse, pushing their

\footnotetext{
${ }^{743}$ Paulinus, Vita Ambrosii, xl.

${ }^{744}$ Paulinus, Vita Ambrosii, xlvii. Paulinus mentions Bassianus of Lodi and Honoratus of Vercelli; others may be inferred.

${ }^{745}$ Paulinus, Vita Ambrosii, xlvi. Simplicianus did succeed him, outliving his pupil by only three years, to be succeeded by Venerius, whom Paulinus mentions as one of those who heard Ambrose designate his successor.

${ }^{746}$ Paulinus, Vita Ambrosii, xlvii. 3.
} 
way amid the clamouring of the demon-possessed. ${ }^{747}$ Ambrose of Milan was a saint before he was even interred, and Paulinus of Milan devotes the final sections of his biography to the posthumous appearances of the bishop and the miracles that form his hagiography. Oddly enough, there is no mention of who performed the funeral oratio, or what was said. To the end, we see Ambrose only aenigmate, "through a glass darkly,",748 shrouded by the romanitas of his genealogy and the persona of his office.

Of an age that was a witness to the writings and theological influence of Jerome and Augustine, Ambrose of Milan has been largely ignored, or more seriously, trivialized. ${ }^{749}$ The recent scholarship that has re-considered the influence of Ambrose as bishop of Milan has tended to focus on his agenda to promote orthodoxy (Williams), to increase the hegemony of the see as a counter force to the increasingly voracious purpose of Rome to establish primacy in the West (Humphries, Williams, McLynn), to promote the growth of the monarchical episcopate (Wataghin and Wharton) and to appropriate for the Church imperial prerogatives (Edwards (Lewis)), a consummate politician and master stage manager (McLynn). The enigma of Ambrose's personality lends itself to a world of scholarly possibilities. To a certain extent, this paper has co-operated in that view, recognizing that the Christianization of northern Italy, and the proliferation of churches and bishoprics in the fourth and fifth centuries occurred as a function of events that were not only polyvalent in their purposes, motivations and effects, but inextricably entwined.

However, in many ways, the protection and establishment of Christianity by the imperial incumbents required a vastly different approach to the conceptual actualization

\footnotetext{
${ }^{747}$ Paulinus, Vita Ambrosii, xlviii.

748 Corinthians 13: 12

${ }^{749}$ Ivor Davidson, “Ambrose," The Early Christian World, II, ed. Philip F. Esler (London and New York: Routledge, 2000), 1175.
} 
of the design and architecture of Christian sacred space. Although pagan temples had housed images of the gods, no community of worshipers intruded into that house. And while synagogues provided a communal setting for the teaching and study of the sacred literature of Judaism, the sacrifice of God's worship was restricted to the Temple Mount of Jerusalem. There the inner sanctum of God's presence was a place so holy that only the High Priest could enter it, and only once a year. The rituals of sacrifice were ended when the Temple was destroyed by the Romans in 70 .

For Christianity, a religion that combined both communal worship and initiation with priestly sacrifice, the requirement for an appropriate structure that could be shared among the liturgies of all the orders, bishops, priests, deacons, and laity, posed a significant challenge that required a new consideration of the use and design of sacred space. The church building, as architecture, represented a revolution in how the god and the community of the faithful would be joined in an embrace of common sacred space.

When we have reduced our focus to this very basic reality, that churches provided a venue for the actualization of the worship of the Christian god, and that their architecture had to accommodate both the symbolism and the dynamic action of the Christian theology in its liturgy, and serve the congregational requirements of the Christian communities, then, at least in northern Italy, Ambrose of Milan must be considered a pivotal player upon a stage where neither Jerome nor Augustine ever ventured. In the short span of twenty-three years, the three (possibly four) monumental churches that he built in Milan dominated the sacred space of the city, and it should not be forgotten that each of these churches was intended to be a congregational church for the Christian communities that surrounded them, near the prominent gates of the city. It 
is quite true that Ambrose himself viewed his church-building as the triumph of his personal efforts to eliminate heresy in the north. His co-opting of the plan of Constantine's Apostoleion and the typography of his own B. Apostolorum was a considered and conscious choice that flaunts that triumph, placed prominently on the adventus route of Milan, designed as the Cross Triumphant. But the question that needs to be asked remains how that triumph would have resonated with the average Milanese, resorting to his church of a Sunday or for the daily office of psalmody. I cannot help but feel that the single-mindedness of Ambrose's program to promote orthodoxy with the concomitant creation of bishoprics, and the solid stability of his vision did resonate with his congregation, both in Milan, and by extension, in the northern Italian corridor of the Milanese see's suffragans. In the number of churches that were constructed, architecture promoted a liturgy that made theology accessible. And if Ambrose did incorporate imperial ceremonial into the stately, holy, mysterious liturgy of the rite of Milan, it was a ceremonial to which few would have been privileged heretofore and in which now all could share, elevating their worship to the level of the emperors.

For the next three centuries, the single-naved, Latin cruciform church was reiterated across the span of the Italian boot and north to the Transalpine countries, frequently aligned with its symbolic associations of dedication to the Apostles. Edwards (Lewis)' contention that these churches derived their impetus from imperial aulic architecture $^{750}$ finds its validity only in the sui generis of the Ambrosian foundations. When Honorius removed the imperial honor from Milan in 402, that impetus was also removed. But Christian worship continued, re-enacted in the Ambrosian liturgy which

\footnotetext{
${ }^{750}$ Edwards (Lewis), “Two Critical Aspects of Fourth-Century Architecture at Milan,” 215.
} 
continued to service that worship, and found expression in the architecture of city cathedrals and parish churches.

The hypothesis that church architecture must represent a function of the dynamics of the liturgy that is played on the stage of sacred space appears to be a non sequitur at the most fundamental level. Yet defining fourth century practice at the moment when the liturgies of the great primatial sees coalesced remains an elusive exercise which requires the patient culling of a variety of sources. The Ambrosian liturgy of Milan, which was very obviously not Ambrosian, was nevertheless defended by the archbishop, and extended through his influence to the sees of northern Italy, whose bishops were groomed in the episcopal court of Milan. As we examine the churches of the suffragan sees, we are forced to recognize that church architecture remained experimental, but drew its initial inspiration from Milan as the source of the prevailing liturgy.

Ambrose's unabashed and enthusiastic promotion of the cult of the saints, particularly in the fortuitous discovery of Gervasius and Protasius, appears both selfserving and manipulative, and without the experience of actually living in the fourth century, it is difficult to separate the appearances from the actual context of the time. This period, with the constant pressure of migratory tribes from the north, and the instability of imperial protection, was a period fraught with anxiety and danger. For the ordinary faithful, the cult of the saints tapped into the well-spring of grass roots devotion that made religion intensely accessible. Without the fervent co-operation of the people themselves, the cult of the saints could not have enjoyed such a persistent and pervasive influence, nor could it have dominated the requirements of church architecture so completely. Even the smallest and poorest parish church could enjoy the protection of a 
locally beloved saint, and provide for a chapel, an oratory, or perhaps, only a niche with a side altar. Often these structures were endowed by private citizens, such as the Paduan oratory of St. Prosdicimus, and here again, the use of the cross became a common architectural statement. As Krautheimer has noted, the martyrial or cultic chapel is a feature which defines the northern Italian churches. ${ }^{751}$ What is extraordinary is the number of churches that were dedicated to the saints of the Milanese litany, such as are found in Verona, which had virtually no local connection.

Of all the rites of the Church, the one that concerned Ambrose the most was the rite of baptism, and no one can fault either the sincerity of his commitment to his baptizands, or the interest that he took in their catechesis. This should not surprise us; it is in the liturgy of the Eucharist and baptism and in his role as a teaching preacher that the fourth century bishop interacted with his flock most intimately, and if Ambrose's theological treatises appear derivative, we are reassured from numerous sources that his sermons and his catechesis were inspired. The foot-dragging, dilatory Augustine (he of "Lord, give me chastity and continence- but do not give it yet!") ${ }^{752}$ was finally convinced, not by the Neo-Platonism or the classical philosophy of the bishop's sources, but by his scriptural exegesis, an area in which Ambrose excelled and to which he gave much thought. Ambrose's embrace of the mysticism of the number eight (which originated in his exegesis and pre-figured the medieval fascination of the mysticism of numbers), and the translation of the octagon to the eschatological symbolism of the baptistery provided a structural model that was duplicated in many cathedrals and countless small churches, such as SS. Felice e Fortunato in Vicenza. Long after the practice of infant baptism

\footnotetext{
${ }^{751}$ Krautheimer, Early Christian and Byzantine Architecture, 175.

${ }^{752}$ Augustine, incidentally, thought Ambrose's enjoined chastity his one significant hardship (Confessions, 6, iii. 3). A recognition of a shared, common burden, no doubt.
} 
became common, separate baptisteries continued to be built. The lavishness of the decorative program that we see in the Neonian baptistery, so closely aligned to the Ambrosian rite, speaks volumes about the importance and holy mystery that the Church associated with the rites of initiation.

If we return to the church that Ambrose designed for his own resting place, the reconstructed Sant'Ambrogio, we might find some indication of how the people of Milan embraced their non-Milanese bishop. There, the magnificent gold and silver altar of Bishop Anghilbertus II and Wolvinus places the Milanese archbishop in the company of the Apostles and among some of the most venerated shrines in Christendom, of which the pre-eminent are located in Constantinople, Jerusalem, and Rome, the sources of the great liturgies of the Catholic Church. ${ }^{753}$ Of the silver panels which depict the hagiography of the saint on the back of the altar, only the two showing Ambrose on horseback (Figures 6 and 7) and two other panels, which depict the visions of the saint of Bishop Honoratus, are without liturgical connections: four have Ambrose at the altar or in a setting with an altar, and four others depict other liturgical actions. ${ }^{754}$

The central third of the altar is formed by a pair of doors of a very large, elaborate fenestrella confessionis which can be opened to expose the saints to the supplication of the devoted; when the doors are opened, there is sufficient space to reach the porphyry sarcophagus (an imperial donation). ${ }^{755}$ The imagery of the doors shows Ambrose crowning Anghilbertus and Wolvinus as he receives their gift on his behalf; Anghilbertus receives a square halo to indicate the bestowal of favor to a still-living recipient. On one

\footnotetext{
${ }^{753}$ Hahn, "Narrative on the Golden Altar of Sant'Ambrogio," 185: the Altar of St. Peter in Rome, the golden altars of both the Constantinian and the Justinianic Hagia Sophia in Constantinople, the golden altar of the Church of the Holy Sepulchre in Jerusalem.

${ }^{754}$ Hahn, "Narrative on the Golden Altar of Sant'Ambrogio," 179.

${ }^{755}$ Hahn, "Narrative on the Golden Altar of Sant'Ambrogio," 180.
} 
side, Bishops Ambrose and Simplicianus are shown depicted in gold repoussé with Saints Gervasius and Protasius, on the other side, Bishops Martin and Maternus are joined by Saints Nabor and Nazarius, Ambrose's two other special saints. In the apse above the altar, the portraits of Milan's suffragan bishops are painted; during the episcopacy of Anghilbertus II, Milan's suffragans reached their greatest number, eleven. ${ }^{756}$

Surrounding the altar, most of the bishops of Milan who succeeded Ambrose have chosen to be buried near his grave, rather than in the cathedral, the seat of their authority. ${ }^{757}$

The Golden Altar of Sant'Ambrogio is a complex work of art that uses images to express meaning on multiple levels, much as Ambrose worked at different levels to expand the development of Christianity in northern Italy and to promote the building of its churches. It simultaneously addresses political, theological, and religious/cultic issues, but of the latter, the most persistent theme is of Ambrose and the liturgy that bears his name. St. Ambrose's ninth century hagiographer spoke for the Milanese see and for the congregations of northern Italy when he wrote, "All that this Milanese church owns in merit and grace, it owes to the magisterium of Ambrose.",758

\footnotetext{
${ }^{756}$ Hahn, "Narrative on the Golden Altar of Sant'Ambrogio," 184.

${ }^{757}$ Hahn, "Narrative on the Golden Altar of Sant'Ambrogio," 184. Simplicianus was translated to the B. Virginum when it was re-dedicated to him.

${ }^{758}$ Hahn, "Narrative on the Golden Altar of Sant'Ambrogio," 184. The $8^{\text {th }}$ century Versum de Mediolano civitate cites the liturgy as one of the glories of Milan.
} 


\section{REFERENCES}

\section{Primary Sources}

Ambrose (including Paulinus, The Life of St. Ambrose), ed. Boniface Ramsey. London and New York, NY: Routledge, 1997.

Davis-Weyer, Caecilia. Early Medieval Art 300-1150, Sources and Documents. Toronto: University of Toronto Press, 2006.

Early Latin Theology: Selections from Tertullian, Cyprian, Ambrose and Jerome. Translated and edited by S. L. Greenslade. Philadelphia: The Westminster Press, 1961.

Egeria. Travels, translated with supporting documents and notes by John Wilkinson. Warminster: Aris and Phillips, 2002.

Hippolytus. On the Apostolic Tradition, translated and edited by Alistair Stewart-Sykes. Crestwood, NY: St. Vladimir's Seminary Press, 2001.

Mango, Cyril. The Art of the Byzantine Empire: 312-1453, Sources and Documents. Toronto: University of Toronto Press, 2000.

Saint Ambrose, translated by Ivor J. Davidson. De Officiis, Volumes I and II. Oxford: Oxford University Press, 2001. , translated by Sister Mary Melchior Beyenka, O.P. Letters. New York: Fathers of the Church, Inc., 1954. , translated by Roy J. Deferrari. Theological and Dogmatic Works. Washington, D.C.: The Catholic University of America Press, 1963.

Saint Augustine, translated by J. G. Pilkington. Confessions: Book V, Chapters XIII and XIV, Book VI, Chapters I-V, Book IX, Chapters V-VIII. Medieval Literature in Translation, ed. Charles W. Jones. Mineola, NY: Dover Publications, Inc., 2001. 


\section{Secondary Sources}

Alexander, James. "Donatism," The Early Christian World, V. II, ed. Philip F. Esler. London and New York: Routledge, 2000, 952-974.

Anson, Peter Friedrich. Churches, Their Plan and Furnishings. Milwaukee: Bruce Publishing, 1948.

Asiedu, F. B. A. "The Song of Songs and the Ascent of the Soul: Ambrose, Augustine, and the Language of Mysticism," Vigilae Christianae, V. 55, 3 (2001), 299-317.

Baldovin, John F. The Urban Character of Christian Worship: The Origins, Development, and Meaning of Stational Liturgy. Rome: Pont. Institutum Studiorum Orientalium, 1987.

Betramini, Guido and Antonio Padoan, eds. Andrea Palladio: the complete illustrated works. New York: Universe, 2001.

Bovini, Giuseppe. Chiese di Ravenna. Novara: Istituto Geografico dei Agostini, 1957.

Bradshaw, Paul F. The Search for the Origins of Christian Worship: Sources and Methods for the Study of Early Liturgy. New York: Oxford University Press, 2002.

. "The Effects of the Coming of Christendom on Early Christian Worship," The Origins of Christendom in the West, ed. Alan Kreider. Edinburgh : T and T Clark Ltd, 2001.

Brakke, David. "Athanasius," The Early Christian World, V. II, ed. Philip F. Esler. London and New York: Routledge, 2000, 1102-1127.

Brenk, Beat. Architettura e Immagini del Sacro nella Tarda Antichita. Spoleto: Fondazione Centro Italiano di Studi Sull'Alto Medioevo, 2005.

Brogiolo, G. P. "Ideas of the Town in Italy during the Transition from Antiquity to the Middle Ages," The Idea and Ideal of the Town Between Late Antiquity and the Early Middle Ages, eds. G. P. Brogiolo and Bryan Ward-Perkins. Leiden: Kloninklijke Brill, 1999.

Brown, Dennis. “Jerome," The Early Christian World, V. II, ed. Philip F. Esler. London and New York: Routledge, 2000, 1151-1174.

Brown, Peter Robert Lamont. The Cult of the Saints : Its Rise and Function in Latin Christianity. Chicago: University of Chicago Press, 1980. 
Cantor, Norman F. The Civilization of the Middle Ages. New York: Harper Collins, 1993.

Caraher, William R. "Church, Society, and the Sacred in Early Christian Greece." $\mathrm{Ph}$. D. Diss., Ohio State University, Columbus, OH, 2003.

Colish, Marcia. Ambrose's Patriarchs: Ethics for the Common Man. Notre Dame, IN: University of Notre Dame Press, 2005.

Conybeare, F. C. "The History of Christmas," The American Journal of Theology, V. 3, 1 (January 1899), 1-21.

Cramer, Peter. Baptism and Change in the Early Middle Ages. Cambridge: Cambridge University Press, 1993.

Crook, John. The Architectural Setting of the Cult of the Saints in the Early Christian West c. 300-1200. Oxford: Clarendon Press, 2000.

Davidson, Ivor. "Ambrose," The Early Christian World, V. II, ed. Philip F. Esler. London and New York: Routledge, 2000, 1175-1204.

Davis, Stephen J. The Cult of Saint Thecla: A Tradition of Women's Piety in Late Antiquity, Oxford: Oxford University Press, 2001.

Dix, Gregory. The Shape of the Liturgy, $2^{\text {nd }}$ edition. London: A. and C. Black, Ltd., 1945.

Duchesne, Louis. Christian Worship: Its Origin and Evolution, translated by M. L. McClure. London: Society for Promoting Christian Knowledge, 1904.

. Early History of the Christian Church: From its Foundation to the End of the Fifth Century. Volume II, The Fourth Century. London: John Murray, 1950.

Dudden, F. Homes. The Life and Times of St. Ambrose. Oxford: The Clarendon Press, 1935.

Edwards (Lewis), Suzanne. See the entry for "Lewis, Suzanne Edwards.

Ferguson, Everett. "Catechesis and Initiation," The Origins of Christendom in the West, ed. Alan Kreider. Edinburgh : T and T Clark Ltd, 2001.

Flanigan, C. Clifford, Eva Louise Lillie, and Nils Holger Petersen. Liturgy and the Arts in the Middle Ages : Studies in Honour of C. Clifford Flanigan.

Copenhagen S.: Museum Tusculanum Press, University of Copenhagen, 1996. 
Fraser, Antonia. Mary Queen of Scots. NewYork, NY : Dell Publishing, 1993.

Frazier, Alison. "Reconsidering an Enigmatic Bobbio Codex (Paris, BN, MS Lat. 13246," review, H-Net Reviews, September 2005 of The Bobbio Missal : Liturgy and Religious Culture in MerovingianGaul, eds. Hen Yitzhak and Rob Means, New York, NY : Cambridge UniversityPress, 2004

Gerov, George. "The Narthex as Desert: The Symbolism of the Entrance Space in Orthodox Church Buildings," Ritual and Art: Byzantine Essays for Christopher Walter, ed. Pamela Armstrong. London: The Pindar Press, 2006.

Gilliard, Frank D. "Senatorial Bishops in the Fourth Century," The Harvard Theological Review, V. 77, 2 (April 1984), 153-175.

. "More Silent Reading in Antiquity: Non Omne Verbum Sonabat," Journal of Biblical Literature, Vol. 112, 4 (Winter, 1993) 689-694.

Grabar, André. Martyrium: Recherches sur le culte des reliques et l'art chrétien antique, I (Architecture). London: Varorum Reprints, 1972.

. Early Christian Art From the Rise of Christianity to the Death of Theodosius, translated by Stuart Gilbert and James Emmons. New York, NY: Odyssey Press, 1968.

Hahn, Cynthia. "Narrative on the Golden Altar of Sant'Ambrogio in Milan: Presentation and Reception," Dumbarton Oaks Papers, 53, 1999: 167-187.

Harrison, Carol. "Augustine,” The Early Christian World, V. II, ed. Philip F. Esler. London and New York: Routledge, 2000, 1205-1227.

Hemans, Charles I. A History of Ancient Christianity and Sacred Art in Italy. London: Williams and Norgate, 1866.

Hubert, Jean, J. Porcher and W. F. Volbach; translated by Stuart Gilbert and James Emmons. Europe of the Invasions. New York: G. Braziller, 1969.

Humphries, Mark. Communities of the Blessed: Social Environment and Religious Change in Northern Italy, AD 200-400. New York: Oxford University Press, 1999.

Jeanes, Gordon. "Baptism Portrayed as Martydom in the Early Church," Forms of Devotion: Conversion, Worship, Spirituality and Asceticism, ed. Everett Ferguson. New York: Garland Publishing Company, 1999: 62-80. 
Jenson, Anne. "Women in the Christianization of the West," The Origins of Christendom in the West, ed. Alan Kreider. Edinburgh: T \& T Clark, 2001.

Jones, Alexander, General Editor. The Jerusalem Bible. Garden City, N. Y.: Doubleday, 1968.

King, Archdale A. Liturgies of the Primatial Sees. London: Longmans, Green, and Co., Ltd, 1957.

Kantorowicz, Ernst H. "Baptism of the Apostles," Dumbarton Oaks Papers, IX and X, 1956, 203-252.

Klauser, Theodor. A Short History of the Western Liturgy: An Account and Some Reflections, translated from the German by John Halliburton. London: Oxford University Press, 1969.

Kostof, Spiro. The Orthodox Baptistery of Ravenna. New Haven: Yale University Press, 1965.

Krautheimer, Richard. Early Christian and Byzantine Architecture. New Haven and London: Yale University Press, 1986.

.Three Christian Capitals: Topography and Politics. Berkeley: University of California Press, 1983.

."Introduction to an Iconography of Medieval Architecture," Journal of the Warburg and Cortauld Institutes, V, 1942: 1-33. 1967: 117- 140

. "The Constantinian Basilica," Dumbarton Oaks Papers, XXI,

Kreider, Alan. "Changing Patterns of Conversion in the West," The Origins of

Christendom in the West, ed. Alan Kreider. Edinburgh: T \& T Clark, 2001.

Lebreton, Jules and Jacques Zeiller. The History of the Primitive Church, V. II, Books III and IV. New York, NY: The MacMillan Company, 1949.

Leitzmann, Hans and Robert Douglas Richardson. Mass and Lord's Supper: a Study in the History of the Liturgy, translation with appendices by Dorothea H. G. Reeve. Leiden: E. J. Brill, 1953. 
Lewis, Suzanne Edwards. "Function and Symbolic Form in the Basilica Apostolorum at Milan," Journal of the Society of Architectural Historians, 28 (2), 1969: 83-98.

. "The Latin Iconography of the Single-Naved Cruciform Basilica Apostolorum in Milan," Art Bulletin, 51 (1969): 205-219.

. "Problems of Architectural Style and the Ambrosian Liturgy in Late Fourth-Century Milan," Hortus Imaginum: Essays in Western Art, ed. Robert Enggass and Marily Stokstad. Lawrence, KS: University of Kansas, 1974: 1117.

. "Two Critical Aspects of Fourth-Century Architecture at Milan: The Single-Nave Cruciform Basilica and the Palace Church.” Ph.D. diss., University of Michigan, 1964.

Lowden, John. Early Christian and Byzantine Art. London: Phaidon Press, 2003.

MacCormack, Sabine G. Art and Ceremony in Late Antiquity. Berkeley: University of California Press, 1981.

MacDonald, William. Early Christian and Byzantine Architecture, New York, NY: Greorge Braziller, 1982.

Mackie, Gillian Vallance. Early Christian Chapels in the West: Decoration, Function and Patronage. Toronto: University of Toronto Press Inc., 2003.

Magagnato, Licisco. Palladio e Verona: catalogo della mostra a cura di Paola Marini: saggi critici eschede di Howard Burns. Verona : Neri Pozza, 1980.

Markus, R. A. "How on Earth Could Places Become Holy? Origins of the Christian Idea of Holy Places," Forms of Devotion : Conversion, Worship, Spirituality and Asceticism, ed. Everett Ferguson. New York : Garland Publishing Company, 1999.

Mathews, T. F. "An Early Roman Chancel Arrangement and It's Liturgical Functions," Rivista di Archeologia Cristiana, 1962: 73-95.

. The Early Churches of Constantinople : Architecture and Liturgy, University Park, PA: The Pennsylvania State University Press, 1971.

- "Review [untitled] of Refiguring the Post Classical City : Dura Europos, Jerash, Jerusalem and Ravenna by Annabel Jane Wharton," Speculum, V. 73, 1 (January 1998), 279-282.

McLynn, Neil B. Ambrose of Milan : Church and Court in a Christian Capital. Berkeley: University of California Press, 1994. 
Noble, Thomas F. X. and Thomas F. Head, eds. Soldiers of Christ: Saints and Saints' Lives from Late Antiquity and the Early Middle Ages. University Park, PA: Pennsylvania State University Press, 1995.

Pettinà, Giuseppe. Vicenza: con 146 illustrazioni e 1 tavola. Bergamo : Instituto italiano d'arti grafiche, 1905.

Piva, Paolo. "L’ipotetica basilica doppia di Milano e la liturgia ambrosiana," Antiquité tardive, 1996, 129-132.

Ploeg, Kees van der. Art, Architecture and Liturgy : Siena Cathedral in the Middle Ages. Groenigen : Forsten, 1993.

Rankin, David. "Arianism," The Early Christian World, V. II, ed. Philip F. Esler. London and New York: Routledge, 2000, 975-1004.

Rouet, Albert. La liturgie et les arts : translated from the French by Paul Philibert. Collegeville, MI : Liturgical Press, 1997.

Sanderson, Warren. Early Christian Buildings : A Graphic Introduction 300 to 600, Champlaine, Ny : Astrion Publishing, 1993.

Shepherd, Massey H, Jr. "Liturgical Expressions of the Constantinian Triumph," Dumbarton Oaks Papers, XXI (1967): 59-78.

Oaks Papers, XV, 23-44.

Sivan, Hagith. "Who was Egeria ? Piety and Pilgrimage in the Age of Gratian," The Harvard Theological Review, V. 18, 1 (January, 1988) 59-72.

Speiser, J.-M. "Ambrose's Foundations at Milan and the Question of Martyria," Urban and Religious Spaces in Late Antiquity and Early Byzantium. Burlington, VT: Ashgate Publishing Company, 2001.

Suitner Nicolini, Gianna ; traduit de l'italien par Norbert Vaillant. Vénétie Romane. La Pierre-qui-Vire, Yonne: Zodiaque, 1991.

Taft, Robert F. "The Byzantine Imperial Communion Ritual," Ritual and Art : Byzantine Essays for Christopher Walter, ed. Pamela Armstrong. London: The Pindar Press, 2006.

. "The Liturgy of the Great Church : An Initial Synthesis of Structure and Interpretation on the Eve of Iconoclasm," Dumbarton Oaks Papers, V. 34 (1980-1981), 45-75. 
Temple, Nicholas. "Conversion and Political Expedience : Imperial Themes in the Early Christian Baptistery," Anales del Instituto de Investigaciones Estéticas, XXIV, 80 (Spring), $2002: 5-45$.

Testa, Rita Lizzi. "Christianization and Conversion in Northern Italy," The Origins of Christendom in the West, ed. Alan Kreider. Edinburgh : T and T Clark Ltd, 2001.

Ulrich, Jörge. "Nicea and the West," Vigiliae Christianae, V. 51, 1 (March 1997), 10-24.

Ward-Perkins, Bryan. From Classical Antiquity to the Middle Ages : Urban Public Building in Northern and Central Italy A. D. 300-850. Oxford : Oxford University Press, 1984.

Wataghin, G. Cantino. "The Ideology of Urban Burials," The Idea and Ideal of the Town Between Late Antiquity and the Early Middle Ages, eds. G. P. Brogiolo and Bryan Ward-Perkins. Leiden: Kloninklijke Brill, 1999.

. "Architecture and Power: Churches in Northern Italy from The $4^{\text {th }}$ to the $6^{\text {th }}$ C." Social and Political Life in Late Antiquity, eds. William Bowden, Adam Gutteridge, and Carlos Machado. Leiden, Boston: Brill, 2006.

Weiss, Jessica. "The Relationship between Ritual and Space at the Neonian Baptistery of Ravenna," a paper presented at the Graduate Colloquium of the University of Alberta: Inner Sanctums, Outer Spaces, 2006.

Wharton, Annabel Jane. "Ritual and Reconstructed Meaning: The Neonian Baptistery in Ravenna," The Art Bulletin, V. 69, 3 (September 1987), 358-375.

. Refiguring the Post Classical City: Duro Europos, Jerash, Jerusalem, and Ravenna. Cambridge, Cambridge University Press, 1995.

White, Andrew Walker. The Artifice of Eternity: A study of Liturgical and Theatrical Practices in Byzantium. Ph. D. Dissertation, University of Maryland. College Park, MD, 2006.

White, L. Michael. "Architecture the first five centuries," The Early Christian World, V. II, ed. Philip F. Esler. London and New York: Routledge, 2000, 693-746.

Williams, Daniel H. Ambrose of Milan and the End of the Nicene-Arian Conflicts. Oxford: Clarendon Press, 1995.

Williams, Kim. Italian Pavements: Patterns in Space. Houston, TX: Anchorage Press, 1997.

Winkler, Gabriele. Studies in Early Christian Liturgy and Its Context. Brookfield, VT: Ashgate Publishing Company, 1997. 
Wright, David F. "Augustine and the Transformation of Baptism," The Origins of Christendom in the West, ed. Alan Kreider. Edinburgh : T and T Clark Ltd, 2001.

Von Simson, Otto G. Sacred Fortress: Byzantine Art and Statecraft in Ravenna. Princeton, NJ: 1987.

Yarnold, E. J. "The Ceremonies of Initiation in the De Sacramentis and De Mysteriis of S. Ambrose," Studia Patrista : Papers presented to the Second International Conference on Patristic Studies Held at Christ Church, Oxford, Vol. 10, eds. Kurt Aland, F. L. Cross, Elizabeth A. Livingston. Berlin : Akademie Verlag, 1970.

Zovatto, Paolo Lino. "Arte Paleocristiana a Verona," Verona e is suo territorio, I, 1960: 553-613.

. "Il significato della basilica doppia: l'esempio di Aquileia," Rivista di storia della chiesa in Italia, 20, 1964: 357-398.

\section{Internet Resources}

Archdiocese of Milan: http://www.chiesadimilano.it/

http://campus.belmont.edu/honors/byzart2001/byzindex.html

http://commons.wikimedia.org/wiki/Image:0334 - Milano - San_Nazaro _-

Cappella_Trivulzio__Facciata__Foto_Giovanni_Dall\%27Orto_5-May-2007.jpg

The Church of Jesus Christ of Latter Day Saints, The Scriptures Internet Edition, http://scriptures.lds.org/biblemaps/13.

http://www.fourthcentury.com/index.htm?http\&\&\&www.fourthcentury.com/jerome/jero me worksnew.htm

http://www.grigaitis.net

http://www.h-net.msu.edu/reviews/showrev.php?id=11136

The Medieval Sourcebook: s. v. "Ambrose of Milan", Letter 22: The Finding of SS Gervasius and Protasius, www.fordham.edu/hatsall/source/ambrose letter22.html.

McClure M.L. and C. L. Feltoe, eds. and trans.

London: Society for Promoting Christian Knowledge, 1919.

http://www.ccel.org/m/mcclure/etheria.htm

http://mosaicartsource.wordpress.com/2007/02/06/neonian-baptistry-ravenna-italy/ 
New Advent, The Catholic Encyclopedia Online, s. v. "Ambrosian Liturgy and Rite," http://www.newadvent.org/cathen/01394a.htm.

New Advent, The Catholic Encyclopedia Online, s.v. "Anaphora," http://www.newadvent.org/cathen/01451a.htm.

New Advent, The Catholic Encyclopedia Online, s.v. "Arianism," http://www.newadvent.org/cathen/01707c.htm.

New Advent, The Catholic Encyclopedia Online, s.v. "Beatification and Canonization," http://www.newadvent.org/cathen/02364b.htm

New Advent, The Catholic Encyclopedia Online, s.v. "Donatists," http://www.newadvent.org/cathen/05121a.htm.

New Advent, The Catholic Encyclopedia Online, s.v. "Epiklesis," http://www.newadvent.org/cathen/05502a.htm.

New Advent, The Catholic Encyclopedia Online, s.v. "First Council of Nicea," http://www.newadvent.org/cathen/11044a.htm.

New Advent, The Catholic Encyclopedia Online, s. v. "St Zeno," http://www.newadvent.org/cathen/15754d.htm.

New Advent, The Catholic Encyclopedia Online, s. v. "Tonsure," http://www.newadvent.org/cathen/14779a.htm.

http://www.newliturgicalmovement.org/2008/02/lighting-of-faro-in-ambrosian-rite.html

Old and New Antiques Digest, http://www.oldandsold.com/articles30/venetia-15.shtml.

Palmer, Origines Liturgicae 07, Vol. I: Dissertation on Primitive Liturgies, Sect. VIII, The Canterbury Project, http://anglicanhistory.org/palmer/palmer7.html.

Ross, Kelley L, PhD (2004). The Proceedings of the Friesian School, Fourth Series. http://www.friesian.com/italia.htm\#milanbishop.

http://www.sacred-destinations.com/italy/ravenna-battistero-neoniano.htm

http://www.sforzinda.it/italia/lombardia/milano/cagrandacortegiustizia/slides/01\%20S.Na $\underline{\mathrm{z} \% \mathrm{E} 0 \mathrm{ro} . \mathrm{html}}$

http://www.tertullian.org/fathers/ambrose_letters_01_letters01_10.htm\#Proceedings

http://www.verona.com

http://www.vicenza.com/temi/vicenza_sacra/chiese_vicenza/felice_fortunato.shtml 
http://www.villas-in-italy.net/holiday/vicenza02.htm

Villanova University, Pelligrinagio in Italia, http://www3.villanova.edu/mission/Pellegrinaggio/2007/slide.pdf

http://www.webdiocesi.chiesacattolica.it/pls/cci dioc new/V3 S2EW CONSULTAZIO NE.mostra pagina?id pagina $=4264$

http://wings.buffalo.edu/AandL/Maecenas/italy_except_rome_and_sicily/milan/ac861604 $\underline{\text { html }}$ 


\section{APPENDIX I}

\section{GLOSSARY ${ }^{759}$}

Acanthus. An architectural ornament resembling the acanthus plant's leaves and that is integral to the design of Corinthinian capitals.

Aedicula. Architecturally, a niche framed usually by a pair of columns, piers, or pilasters, surmounted by a gable or lintel, and often with a plaque.

Agape. A meal of semi-ritual character shared among the early Christian congregation.

Agora. The marketplace in a Greek city, usually its economic center.

Ambo. Freestanding pulpit.

Ambulatory church. In which a domed or half-domed semicircular bay terminating the nave is enclosed by a continuous contiguous space, the ambulatory, coursing from the ends of the aisles.

Anaphora.* A collection of liturgies of the Greek rites, dating from the fourth to the fifth century, corresponding to the Latin Canon of the Mass, the offering of the Eucharistic Bread, the large veil that covers the Eucharistic Bread, and the procession in which the offering is brought to the altar.

Antipendium. Decorative panel or cloth at the font of an altar.

Architrave. A lintel of stone or timber placed horizontally and supported by columns or piers, this is the lowest member of the entablature.

Arcosolium. Arched recess for burial in crypts and catacombs.

Acroterium. (pl. acroteria). A sculptural embellishment at the three angles of a pediment.

Ashlar. Masonry consisting of evenly cut, usually large stones.

\footnotetext{
${ }^{759}$ Warren Sanderson, Early Christian Buildings: A Graphic Introduction 300 to 600, Champlain, NY: Astrion Publishing, 1993, 92-98. The glossary is included as a useful aid to the introduction of Late Antique/Early Christian architecture and liturgy.

*Addition by the author.
} 
Atrium. In Early Christian and Byzantine architecture, the forecourt of a church; usally enclosed by four colonnaded porticoes [quadriporticus].

Aula. (adj. aulic) A Latin term sometimes employed for the nave of a church [its original meaning is "hall" or "congregational space."].

Baldachin. Domed or pedimented superstructure supported on slender columns, usually marking or protecting a particular place.

Baldacchino. A free-standing canopy that rises above a throne, altar, or tomb.

Baptistery. A central type, usually domed building at a cathedral, devoted to the sacrament of baptism by immersion in water for early Christians.

Barrel-vault. A half-cylindrical vault, the projection of an arch into a space; also termed a tunnel-vault.

Basilica. An assembly room. In Christian context usually a longitudinal church most often with nave and side aisles, the former rising into a clerestory and topped by a roofing system most often of wood.

Basilica discoperta. A basilica type thought to consist of roofed aisles and uncovered nave.

Bay. A unit of space often rectangular in plan and delimited by supports rising along two parallel sides or at its corners.

Bema. Sanctuary of a church or synagogue, where the prescriptions of the liturgy are performed, often screened in, sometimes raised.

Brandea: Strips of cloth once in contact with a holy relic to absorb its powers.

Capsa. Latin word for a reliquary chest.

Cardo. The main axial north-south street in a Roman settlement. Compare to Decumanus.

Castrum (pl. castra). Fortified place, usually but not always a military camp.

Catechumen. In early Christianity, a convert under instruction but not yet baptized.

Cathedra. The bishop's throne, usually in a cathedral.

Chevet. An apsidal ending of a church.

Ciborium. A permanent canopy placed over an altar. See Baldacchino. 
Cloister-vault. A domical vault, may also be a four-sided, or eight-sided dome.

Chancel. A screened area at the east of the nave reserved for clergy and choir, and usually containing the high altar.

Clerestory (or clearstory). A wall continuing the nave arcade above the side aisles and pierced by windows.

Coenobite (cenobite). In monasticism, one who lives a communal life.

Coenobium (cenobium). A monastery organized for the communal life of a monastic congregation.

Conch. A semicircular niche larger than an aedicule and surmounted by a half dome.

Cochlias. Derived from cochlea (snail), often denoting a spiral stairway.

Confessio. Within a church, this is a subterranean chamber or recess below or near an altar and sheltering a relic.

Corbel. A stone or brick projecting from the face of a wall and serving as a support.

Corbel table frieze. A series of small arches that rest upon corbels.

Crossing. The space at the intersection of nave and transept.

Crypt. Usually in a church, often in early Christian cemeterial chapels, a vaulted chamber containing graves or relics beneath the main floor, but not necessarily fully underground.

Decumanus. Main axial east-west street in a Roman settlement (see Cardo).

Diaconicon. A room attached to the end of the south aisle or within an early Christian church; received the congregation's offerings and served as archvestry and library. Later used only for the latter functions as sacristy.

Dome. A hemispherical vault supported by a circular wall; over a square space, by pendentives in the corners that transform the square into a circle; or over an octagon, by squinches that bring the octagon nearer to the form of a circle.

Domed basilica. A church of square or short rectangular plan with a vaulted nave, aisles, and galleries, and a dome surmounting the nave's center bay.

Domus. A large house of a well to do family. 
Domus ecclesia. A private house that has become a permanent center for the religious, administrative, and charitable needs of a community.

Double cathedral. An early Christian cathedral consisting of two halls or basilicas upon parallel or unilinear axes as a rule; the two structures apparently served separate functions that are not yet fully understood.

Elevation. Drawing of the vertical organization of a building, it may show the rising walls, columns, arcades, etc., or an external vertical surface.

Entablature. The superstructure supported by columns, and usually in three parts: architrave, frieze, and cornice.

Epiklesis (var. epiclesis).* The name of the prayer (Latin invocatio) that occurs in all Eastern liturgies (and originally in Western liturgies) after the Eucharistic words of Institution, in which the celebrant prays that God may send down His Holy Spirit to change the bread and wine into the Body and Blood of His Son. Theologically, a significant diversion exists between the Eastern and the Western Church in which the Eastern Church believes that it is this prayer, and not the Institution, which is the essential component of the miraculous transformation of the bread and wine.

\section{Esonarthex. See Narthex.}

Eucharist. The celebration of "giving of thanks" by Christians during the liturgy, and more specifically, the consecrated bread and wine of the Mass.

Evangelist. One of the "authors" of the four Gospels.

Exedra. A niche or semicircular apse covered or uncovered that extends a larger room.

Extrados. The outer curvature of an arch or a vault.

Forecourt. An open courtyard before a building.

Frigidarium. Cold water bathing room in the Thermae.

Greek-cross plan. A church plan with vaulted or unvaulted arms of equal or nearly equal length.

Groin-vault. Formed over a square bay by interpenetration of two barrel-vaults of equal diameter and height, with its lines of intersection appearing as a diagonal cross, this is also known as a cross-vault.

\footnotetext{
*Addition by the author.
} 
Ground plan. A diagram or architectural map indicating the locations of walls, foundations, and sometimes the roofing system of structures.

Haikal. Among Christian Arabs, the sanctuary of a church.

Hetoimasia. Literally "preparation," symbolized by a throne with a Gospel book upon it, conveys the meaning of the Second Coming.

Hollow tube construction. A vaulting construction that consists of hollow clay conelike tubes, with the narrow, closed end of one inserted into the wide, open end of another. See Tubi fittili.

Hypocaust. System of underground heating ducts in Late Antique baths, basilicas, some early Christian churches, and certain monastic chambers.

Hypogaeum. An underground chamber, or group of chambers for private use; also a burial vault.

Impost block. A block that is placed upon the capital of a colum and supports an arch or vault.

Intrados. The underside of an arch.

Lararium (pl. lararia). A small private niche serving as a shrine or in a chapel and containing the household's gods (Lares).

Locus sanctus (pl. loca sancta). Literally, from the Latin, "Holy place;" the site of an important sacred event of either the Old or New Testament or in the life of a saint.

Loculus tomb. Usually in the catacombs, a rectangular, shelflike niche for burial.

Logos. The "Word:" Greek for God's existence.

Martyrium, Martyrion. Refers to a structure erected over a site that bore witness to the Christian faith. In the holy land, this usually signaled an event in Christ's life or Passion. There and in other parts of the early Christian world it marks the grave of a martyr, a "witness" by virture of having shed blood.

Mensa. A table for celebrating mass; often an altar table in early Christian churches.

Naos. Greek for the sanctuary of a Byzantine centrally-planned church; architecturally and liturgically it is the core area reserved for performing the liturgy. 
Narthex. Transverse rectangular or oblong vestibule to a church, located either before nave and aisles as an inner narthex (esonarthex), or before the façade as an outer narthex (exonarthex). The exonarthex may also function as the portico of a quadriporticus that encloses an atrium.

Nave. The center aisle of a church normally coursing from west to east, and usually accompanied by side aisles.

Occidented. Toward the west, direction of the church's main apse, seldom found after Constantinian churches.

Oculus. The circular opening in a dome or in a wall.

Opus listatum. Masonry of brick and small blocks of stone laid in alternating (sometimes doubled) courses.

Opus mixtum. Masonry construction of mortared rubblework usually faced.

Opus reticulatum. Facing of a wall of square stone, brick, or marble panels set into a diagonal pattern.

Opus sectile. An inlay of colored marble pieces.

Ordo. A liturgical directive from Rome.

Oriented. Toward the east, the normal direction of the apse of a church.

Ossuary. A receptacle for bones and ashes of the body after it has been cremated.

Pallioto.* When applied to an altar, an antependium (hanging) which adorns the altar front, often of decorative material, but distinguished from the altar linens. It may also be an entire piece designed to decorate the altar front. Additionally, the term is sometimes used to refer to the liturgical vestment which is more commonly known as the maniple.

Pantokrator. Christ represented as ruler of the world, frequently in the dome or the apse of a church.

Parekklesion. A chapel that is free-standing or attached.

Pastophory. A room flanking the apse of an early Christian or Byzantine church and serving as a diaconicon or prothesis; also as a library.

*Addition by the author. 
Pendentives. Architecturally, concave triangular segments of a sphere four of which form the circular base upon which a dome (i.e., a pendentive dome) or a dome on drum (i.e., a dome on pendentives) may be erected over a square bay and be supported at the corners of that bay.

Pentimento.* An alteration to a painting (or a building) which indicates that the artist (architect) changed his mind during the construction of the work.

Pilaster. A pier engaged to a wall, but projecting only slightly from it.

Prebyter. Literally, an "Elder." In the early Christian church, a cleric who practices administrative and priestly functions.

Presbyterium. The choir in a church, reserved for the clergy.

Propylaeum. The gateway building to a sacred precinct, whether churchly or imperial.

Prothesis.* A room on the north attached to or enclosed in the church where the species of the Eucharist is prepared before the mass, and usually stored afterward. Liturgically, in Eastern and Byzantine churches, the Rite of Prothesis is the act of preparing the bread and wine for the Eucharist prior to the Mass of the Faithful which begins with the Offertory. The silent prayers said by the priest over the offerings represent the "hidden" years of Christ's earthly life.

Pumpkin dome. Composed of curvilinear segments, this is also termed an umbrella dome and a melon dome.

Pyxis (pl. pyxides). A small box or container.

Quadriporticus. Marks the intersection of two roads with four linked archways.

Quicunx. Pattern or arrangement of five elements, four demarking the corners of a rectangle and one in the center.

Recessed brick masonry. Masonry of alternating brick courses that are recessed from the wall plane and covered by mortar.

Reconstruction. A drawing that shows how a building is supposed to have appeared.

Refrigerium. In the early Christian Church, a funerary banquet that commemorated a martyr or an ordinary mortal.

Reliquary chest. A chest, usually small and ornamented, that contains the bones of a saint, an object that was touched by the saint, or a brandeum.

*Addition by the author. 
Respond. The wall pilaster behind or opposite a column.

Rinceau. Continuous decorative scroll of vines, leaves, plants.

Rotulus. A scroll for reading, preceded the invention of the "codex" or book form.

Salutatorium. Reception hall of a Roman Emperor, or in Christian usage, of the bishop.

Sigma (p. sigmata). A semicircular table in Roman and Byzantine terminology.

Section drawing. A view across the width of a building at a telling juncture.

Socle. A plinth, support for columns or statuary.

Solea. Raised pathway leading from the bema to the ambo in an early Christian or Byzantine church.

Spandrel. The triangular surface between arches and their tangential rectangular framing.

Spolia. Comes from "Spoils," "booty." In architecture it refers to reused materials.

Squinch. A corbelling buildup of small arches into a half-conical niche at the corners of a square bay to form an octagon over which an octagonal cloister-vault or dome may be constructed.

Stoa. Covered hall with roof supported by one or more rows of columns paralleling its rear wall.

Stylobate. A continuous base formed of stone and above floor level. Upon it rise the columns or piers that support the building.

Stylite. One who lives atop a column.

Synthronon. Bench or benches reserved within the chancel area for the clergy in Eastern Christian and Byzantine churches, these may be arranged in a semicircle along the apse wall or in straight rows to either side of the bema.

Temenos. Denotes a sacred precinct.

Tetraconch. A building with four conches usually projecting from a central space.

Tessera. Cut, smoothed cube of marble, glass, or stone, used to create mosaics.

Tetrarchy. Administration of the empire by four rulers instituted by Diocletian in 292 . 
Thermae. In the Roman Empire, a bathing precinct often of monumental proportions constructed for public or private use.

Titulus. In the city of Rome, a domus ecclesiae and its defined, associated property. After Constantine, the twenty-five ecclesiastical and administrative districts of the early Roman Church.*

Trabeation. Construction of horizontal beams, whether in stone or wood.

Tholos. A dome or a round, domed building.

Transept. The tranverse spatial unit of a basilican plan, usually inserted between nave and apse. It may be undivided (a continuous transept), divided into nave and aisles and so continue the division of the main body (cross transept); it may consist of a center bay that continues the nave together with wings as high as the nave or lower, but always separated from the center bay by colonnades (tripartite transept, or, with low wings, dwarf transept).

Transenna. Slab of solid or pierced marble, stone, or metal, usually serving as elements of a balustrade or as a window grill.

Travertine. A type of limestone used for building in Italy.

Trefoil apse. An apse with three semicircular exedrae, found more in early Christian Egypt than other locales.

Tribune. A raised platform upon which a high official presides over governmental, legal, or festal proceedings.

Triclinium. Dining room; derived from the three couches on which Roman diners reclined.

Triconch. A building composed of three conches.

Triconch transept. A transept with wings that end in apses.

\section{Tripartite transept. See Transept.}

Tubi fittili. Hollow terracotta tubes used for their strength and light weight in constructing ceiling vaults. See Hollow Tube Construction.

Tufa. Soft stone used in building, especially in Italy.

*Addition by the author 
Vault. An arcuated roofing system over a space between two parallel walls.

Voussoir. A brick or wedge-shaped stone which forms one of the units of an arch. 


\section{APPENDIX II \\ THE FINDING OF SAINTS GERVASIUS AND PROTASIUS}

\section{Ambrose, Epistolae, 22}

To the lady, his sister, dearer to him than his eyes and life, Ambrose Bishop

1. As I do not wish anything which takes place here in your absence to escape the knowledge of your holiness, you know that we have found some bodies of holy martyrs. For after I had dedicated the basilica, many, as it were, with one mouth began to address me, and said: Consecrate this as you did the Roman basilica. And I answered: "Certainly I will if I find any relics of martyrs." And at once a kind of prophetic ardor seemed to enter my heart.

2. Why should I use many words? God favored us, for even the clergy were afraid who were bidden to clear away the earth from the spot before the grating of Sts. Felix and Nabor. I found the fitting signs, and on bringing in some on whom hands were to be laid, the power of the holy martyrs became so manifest, that even whilst I was still silent, one was seized and thrown prostrate at the holy burial place. We found two men of marvelous stature, such as those of ancient days. All the bones were perfect, and there was much blood. During the whole of those two days there was an enormous concourse of people. Briefly we arranged the whole in order, and as evening was now coming on transferred them to the basilica of Fausta, where watch was kept during the night, and some received the laying on of hands. On the following day we translated the relics to the basilica called Ambrosian. During the translation a blind man was healed. I addressed the people then as follows:

3. When I considered the immense and unprecedented numbers of you who are here gathered together, and the gifts of divine grace which have shown forth in the holy martyrs, I must confess that I felt myself unequal to this task, and that I could not express in words what we can scarcely conceive in our minds or take in with our eyes. But when the course of Holy Scripture began to be read, the Holy Spirit Who spake in the prophets granted me to utter something worth of so great a gathering of your expectations, and of the merits of the holy martyrs. 
4. "The heavens," it is said, "declare the glory of God." When this Psalm is read, it occurs to one that not so much the material elements as the heavenly merits seem to offer praise worthy of God. And by the chance of this day's lessons it is made clear what "heavens" declare the glory of God. Look at the holy relics at my right hand and at my left, see men of heavenly conversation, behold the trophies of a heavenly mind. These are the heavens which declare the glory of God, these are His handiwork, which the firmament proclaims. For not worldly enticements, but the grace of the divine working, raised them to the firmament of the most sacred Passion, and long before by the testimony of their character and virtues bore witness of them, that they continued steadfast against the dangers of this world.

5. Paul was a heaven, when he said: "Our conversation is in heaven." James and John were heavens, and then were called "sons of thunder," and John, being as it were a heaven, saw the Word with God. The Lord Jesus Himself was a heaven of perpetual light, when He was declaring the glory of God, that glory which no man had seen before. And therefore He said: "No man hath seen God at any time, except the onlybegotten Son, Who is in the bosom of the Father, He hath declared Him." And so strengthened against the temptations of the devil, he kept his footsteps constantly without offence. But let us go on to what follows.

6. "Day," it is said, "unto day uttereth speech." Behold the true days, where no darkness of night intervenes. Behold the days full of life and eternal brightness, which uttered the word of God, not in speech which passes away, but in their inmost heart, by constancy in confession, and perseverance in their witness.

7. Another Psalm which was read says: "Who is like unto the Lord our God, Who dwelleth on high, and regardeth lowly things in heaven and in the earth?" The Lord regarded indeed lowly things when He revealed to His Church the relics of the holy martyrs lying hidden and under the unnoted turf, whose souls were in heave, their bodies in the earth: "raising the poor out of the dust, and lifting the needy from the mire," and do you see how He hath "set them with the princes of His people." Whom are we to esteem as the princes of the people but the holy martyrs? Amongst whose number Protasius and Gervasius long unknown are now enrolled, who have caused the Church of Milan, barren of martyrs hitherto, now as the mother of many children, to rejoice in the distinctions and instances of her own sufferings.

8. Nor let this seem at variance with the true faith: "Day unto day uttereth the word;" soul unto soul, life unto life, resurrection unto resurrection; "and night unto night showeth knowledge," that is, flesh unto flesh, they, that is, whose passion has shown to all the true knowledge of the faith. Good are these nights, bright nights, not without stars: "For as star differeth from star in brightness, so too is the resurrection of the dead."

9. For not without reason do many call this the resurrection of the martyrs. I do not say whether they have risen for themselves, for us certainly the martyrs have risen. You know - nay, you have yourselves seen - that many are cleansed from evil spirits, that very many also, having touched with their hands the robe of the saints, are freed from 
those ailments which oppressed them; you see that the miracles of old time are renewed, when through the coming of the Lord Jesus grace was more largely shed forth upon the earth, and that many bodies are healed as it were by the shadow of the holy bodies. How many napkins are passed about! How many garments, laid upon the holy relics are endowed with healing power, are claimed! All are glad to touch even the outside thread, and whosever touches will be made whole.

10. Thanks be to Thee, Lord Jesus, that at this time Thou hast stirred up for us the spirits of the holy martyrs, when Thy Church needs greater protection. Let all know what sort of champions I desire, who are able to defend, but desire not to attack. These have I gained for you, O holy people, such as may help all and injure none. Such defenders do I desire, such are the soldiers I have, that is, not soldiers of this world, but soldiers of Christ.

11. The course of divine Scripture relates that Elisha, when surrounded by the army of the Syrians, told his servant, who was afraid, not to fear: "for," said he, "they that be for us are more than those against us;" and in order to prove this, he prayed that the eyes of Gehazi might be opened, and when they were opened, he saw that numberless hosts of angels were present. And we, though we cannot see them, yet feel their presence. Our eyes were shut, so long as the bodies of the saints lay hidden. The Lord opened our eyes, and we saw the aids wherewith we have been often protected. We used not to see them, but yet we had them. And so, as though the Lord had said to us when trembling, "See what great martyrs I have given you," so we with opened eyes behold the glory of the Lord, which is passed in the passion of the martyrs, and present in their working. We have escaped, brethren, no slight lead of shame; we had patrons and knew it not. We have found this one thing, in which we seem to excel those who have gone before us. That knowledge of the martyrs, which they lost, we have regained.

12. The glorious relics are taken out of an ignoble burying-place, the trophies are displayed under heaven. The tomb is wet with blood. The marks of the bloody triumph are present, the relics found undisturbed in their order, the head separated from the body. Old men now repeat that they once heard the names of these martyrs and read their titles. The city which had carried off the martyrs of other places had lost her own. Though this be the gift of God, yet I cannot deny the favor which the Lord Jesus has granted to the time of my priesthood, and since I myself am not worthy to be a martyr, I have obtained these martyrs for you.

13. Let these triumphant victims be brought to the place where Christ is the victim. But He upon the altar, Who suffered for all; they beneath the altar, who were redeemed by His Passion. I had destined this place for myself, for it is fitting that the priest should rest there where he has bee wont to offer, but I yield the right hand portion to the sacred victims; that place was due to the martyrs. Let us, then, deposit the sacred relics, and lay them up in a worthy resting-place, and let us celebrate the whole day with faithful devotion. 
14. The people called and demanded that the deposition of the martyrs should be postponed until the Lord's Day, but at length it was agreed that it should take place the following day. On the following day again I preached to the people on this sort.

15. Yesterday I handled the verse, "Day unto day uttereth speech," as my ability enabled me; today Holy Scripture seems to me not only to have prophesied in former times, but even at the present. For when I behold your holy celebration continued day and night, the oracles of the prophet's song have declared that these days, yesterday and today, are the days of which it is most opportunely said: "Day unto day uttereth speech;" and these the nights of which it is most fittingly said that "Night unto night showeth knowledge." For what else but the Word of God have you during these two days uttered with inmost affection, and have proved yourselves to have the knowledge of the faith.

16. And they who usually do so have a grudge against this solemnity of yours; and since because of their envious disposition they cannot endure this solemnity, they hate the cause of it, and go so far in their madness as to deny the merits of the martyrs, whose deeds even the evil spirits confess. But this is not to be wondered at since such is the faithlessness of unbelievers that the confession of the devil is often more easy to endure. For the devil said: "Jesus, Son of the living God, why art Thou come to torment us before the time?" And the Jews hearing this, even themselves denied Him to be the Son of God. And at this time you have heard the devils crying out, and confessing to the martyrs that they cannot bear their sufferings, and saying, "Why are ye come to torment us so severely?" And the Arians say: "These are not martyrs, and they cannot torment the devil, nor deliver any one, while the torments of the devils are proved by their own words, and the benefits of the martyrs are declared by the restoring of the healed, and the proof of those that are loosed.

17. They deny that the blind man received sight, but he denies not that he is healed. He says: I who could not see now see. He says: I ceased to be blind, and proves it by the fact. They deny the benefit, who are unable to deny the fact. The man is known: so long as he was well he was employed in the public service; his name is Severus, a butcher by trade. He had given up his occupation when this hindrance befell him. He calls for evidence those persons by whose kindness he was supported; he adduces those as able to affirm the truth of his visitation whom he had as witnesses of his blindness. He declares that when he touched the hem of the robe of the martyrs, wherewith the sacred relics were covered, his sight was restored.

18. Is not this like that which we read in the Gospel? For we praise the power of the same Author in each case, nor does it be a work or a gift, since He confers a gift in His works, and works in His gift. For that which He gave to others to be done, this His Name effects in the work of others. So we read in the Gospel, that the Jews, when they saw the gift of healing in the blind man, called for the testimony of his parents, and asked: "How doth your son see?" when he said: "Whereas I was blind, now I see." And in this case the man says, "I was blind and now I see." Ask others if you do not believe me; ask strangers if you think his parents are in collusion with me. The obstinacy of these men is more hateful that that of the Jews, for the latter, when they doubted, at least 
asked his parents; the others enquire in secret and deny in public, incredulous not as to the work, but as to its Author.

19. But I ask what it is that they do not believe; is it whether any one can be aided by the martyrs? This is the same thing as not to believe Christ, for He Himself said: "Ye shall do greater things than these." How? By those martyrs whose merits have been long efficacious, whose bodies were long since found? Here I ask, do they bear a grudge against me, or against the holy martyrs? If against me, are any miracles wrought by me? By my means or in my name? Why, then, grudge me what is not mine? If it be against the martyrs (for if they bear no grudge against me, it can only be against them), they show that the martyrs were of another faith than that which they believe. For otherwise they would not have any feeling against their works, did they not judge that they have not the faith which was in them, that faith established by the tradition of our forefathers, which the devils themselves cannot deny, but the Arians do.

20. We have today heard those on whom hands were laid say, that no one can be saved unless he believe in the Father, the Son, and the Holy Spirit; that he is dead and buried who denies the Holy Spirit, and believes not the almighty power of the Trinity. The devil confesses this, but the Arians refuse to do so. The devil says: Let him who denies the Godhead of the Holy Spirit be so tormented as himself was tormented by the martyrs.

21. I do not accept the devil's testimony but his confession. The devil spoke unwillingly, being compelled and tormented. That which wickedness suppresses, torture extracts. The devil yields to blows and the Arians have not yet learned to yield. How great have been their sufferings, and yet, like Pharaoh, they are hardened by their calamities! The devil said, as we find it written: "I know Thee Who Thou art, Thou art the Son of the living God." And the Jews said: "We know not whence He is." The evil spirits said today, yesterday, and during the night, We know that ye are martyrs. And the Arians say, We know not, we will not understand, we will not believe. The evil spirits say to the martyrs, Ye are come to destroy us. The Arians say, The torments of the devils are not real but fictitious and made-up tales. I have heard of many things being made up, but no one has ever been able to feign that he was an evil spirit. What is the meaning of the torment we see in those on whom hands are laid? What room is there here for fraud? What suspicion of pretence?

22. But I will not make use of the voice of evil spirits in support of the martyrs. Their holy sufferings are proved by the benefits they confer. These have persons to judge of them, namely, those who are cleansed, and witnesses, namely, those who are set free. That voice is better than that of devils, which the soundness of those utters who came inform; better is the voice which blood sends forth, for blood has a loud voice reaching from earth to heave. You have read how God said: "Thy brother's blood crieth unto Me." This blood cries by its color, the blood cries by the voice of its effects, the blood cries by the triumph of its passion. We have acceded to your request, and have postponed till today the deposition of the relics which was to have taken place yesterday. 


\section{Rites of the Catholic Church}

Rites of the Catholic Church in the West
\begin{tabular}{|l|l|}
\hline \multicolumn{1}{|c|}{ Church } & \multicolumn{1}{c|}{ Area of Practice } \\
\hline \hline \multicolumn{2}{|c|}{ Latin Rite } \\
\hline Ambrosian & Italy - Milan Archdiocese \\
\hline $\begin{array}{l}\text { Mozarabic } \\
\text { (Iberian) }\end{array}$ & Spain - Toledo Archdiocese \\
\cline { 2 - 2 } Roman & Portugal - Bragan Archdiocese \\
\hline
\end{tabular}

\section{Rites of the Catholic Church in the East}

\begin{tabular}{|c|c|c|c|}
\hline Church & Area of Practice & Canonical Status & Date of Reunion \\
\hline \multicolumn{4}{|c|}{ Alexandrian Rite ( Liturgy of St. Mark) } \\
\hline Coptic & Egypt \& Near East & Patriarchate & 1741 \\
\hline Ethiopian/Eritrean & Ethiopia \& Somalia & Metropolitan & 1846 \\
\hline \multicolumn{4}{|c|}{ Antiochene Rite or West-Syrian ( Liturgy of St. James ) } \\
\hline Maronite & Middle East \& Diaspora & Patriarchate & $\begin{array}{l}\text { never separated } \\
\text { re-affirmed } 1182\end{array}$ \\
\hline Syrian & Near \& Middle East & Patriarchate & 1781 \\
\hline Syro-Malankara & India & Major Archepiscopal & 1930 \\
\hline \multicolumn{4}{|c|}{ Armenian Rite ( Greek Liturgy of St.Basil) } \\
\hline Armenian & Near East \& Diaspora & Patriarchate & 1742 \\
\hline \multicolumn{4}{|c|}{ Chaldean Rite or East-Syrian ( Derived from Antiochene Rite) } \\
\hline Chaldean & Near \& Middle East & Patriarchate & 1692 \\
\hline Syro-Malabar & India & Major Archepiscopal & 1599 \\
\hline \multicolumn{4}{|c|}{ Byzantine Rite ( Liturgy of St. John Chrysostom, St. James, St. Basil \& Others ) } \\
\hline Albanian & Albania & without hierarchy & 1628 \\
\hline Belarusian & Belarus & without hierarchy & 1596 \\
\hline Bulgarian & Bulgaria & sui iuris & 1861 \\
\hline Croatian & Croatia \& USA & sui iuris & 1611 \\
\hline Greek & Greece \& Diaspora & sui iuris & 1829 \\
\hline Hungarian & Hungary \& USA & sui iuris & 1646 \\
\hline Italo-Albanian & East \& South Italy & sui iuris & never separated \\
\hline Macedonian & Macedonia & sui iuris & 1918 \\
\hline Melkite & Greece \& Diaspora & Patriarchate & 1726 \\
\hline Romanian & Romania \& USA & Major Archepiscopal & 1697 \\
\hline Russian & Russia \& Diaspora & without hierarchy & 1905 \\
\hline Ruthenian & Ukrainia \& USA & Metropolitan & 1646 \\
\hline Slovackian & Slovackia & sui iuris & 1646 \\
\hline Ukrainian & Ukrainia \& Diaspora & Major Archepiscopal & 1595 \\
\hline
\end{tabular}




\section{CURRICULUM VITAE}

NAME:

ADDRESS:

DOB:

EDUCATION

\& TRAINING:
Sylvia Anne Crenshaw Schneider

272 Hunters Pointe Place

Simpsonville, KY 40067

Fort Sill, Oklahoma - March 2, 1948

B. A. Arts and Science (French and Italian) University of Missouri

1965-1970

Certificate, Finance and Accounting Pennsylvania State University (Shippensburg, PA) 1982-1984

Certificate, Japanese

Defense Language Institute (Monterey, CA)

1984-1985

M. A. Art History

University of Louisville

2005-2008 